\title{
Polyols and polyphenols against glucotoxicity
}

Citation for published version (APA):

Boesten, D. M. P. H. J. (2014). Polyols and polyphenols against glucotoxicity. [Doctoral Thesis, Maastricht University]. Maastricht University. https://doi.org/10.26481/dis.20141201db

Document status and date:

Published: 01/01/2014

DOI:

$10.26481 /$ dis.20141201db

Document Version:

Publisher's PDF, also known as Version of record

\section{Please check the document version of this publication:}

- A submitted manuscript is the version of the article upon submission and before peer-review. There can be important differences between the submitted version and the official published version of record.

People interested in the research are advised to contact the author for the final version of the publication, or visit the DOI to the publisher's website.

- The final author version and the galley proof are versions of the publication after peer review.

- The final published version features the final layout of the paper including the volume, issue and page numbers.

Link to publication

\footnotetext{
General rights rights.

- You may freely distribute the URL identifying the publication in the public portal. please follow below link for the End User Agreement:

www.umlib.nl/taverne-license

Take down policy

If you believe that this document breaches copyright please contact us at:

repository@maastrichtuniversity.nl

providing details and we will investigate your claim.
}

Copyright and moral rights for the publications made accessible in the public portal are retained by the authors and/or other copyright owners and it is a condition of accessing publications that users recognise and abide by the legal requirements associated with these

- Users may download and print one copy of any publication from the public portal for the purpose of private study or research.

- You may not further distribute the material or use it for any profit-making activity or commercial gain

If the publication is distributed under the terms of Article $25 \mathrm{fa}$ of the Dutch Copyright Act, indicated by the "Taverne" license above, 


\title{
Polyols and polyphenols against glucotoxicity
}

\author{
Daniëlle M.P.H.J. Boesten
}


CDaniëlle Boesten, Maastricht, 2014

NUR 882

ISBN 9789056814403

Cover design: Print and Design Canon Business Services, Maastricht

Production: Print and Design Canon Business Services, Maastricht

The studies presented in this thesis were performed within NUTRIM school for Nutrition, Toxicology and Metabolism which participates in the Graduate School VLAG (Food Technology, Agrobiotechnology, Nutrition and Health Sciences), accredited by the Royal Netherlands Academy of Arts and Sciences.

Financial support for printing of this thesis was kindly provided by Cargill Inc. 


\title{
Polyols and polyphenols against glucotoxicity
}

\author{
PROEFSCHRIFT
}

ter verkrijging van de graad van doctor

aan de Universiteit Maastricht,

op gezag van de Rector Magnificus, Prof. dr. L.L.G. Soete

volgens het besluit van het College van Decanen,

in het openbaar te verdedigen

op maandag 1 december 2014 om 14:00 uur

door

Daniëlle Maria Petronella Hubertina Josefina Boesten 


\section{Promotor}

Prof. dr. A. Bast

\section{Copromotor:}

dr. G.J.M. den Hartog

\section{Beoordelingscommissie:}

Prof. dr. F.J.P.H. Brouns (voorzitter)

Prof. dr. P. Leroy (Université de Lorraine, Nancy, France)

Prof. dr. C.G. Schalkwijk

Prof. dr. N.C. Schaper

Prof. dr. H. Verhagen (RIVM) 


\section{Contents}

Chapter $1 \quad$ General introduction 7

Chapter $2 \quad$ Accelerated aging during chronic oxidative stress: a role 27 for PARP-1

Chapter 3 Protective pleiotropic effect of flavonoids on $\mathrm{NAD}^{+}$levels in endothelial cells during high glucose

Chapter $4 \quad$ Effect of $\mathrm{N}^{\varepsilon}$-carboxymethyllysine on oxidative stress and the glutathione system in beta cells

$\begin{array}{lll}\text { Chapter } 5 \quad \text { Health effects of erythritol } & 77\end{array}$

Chapter $6 \quad$ Multi-targeted mechanisms underlying the endothelial $\quad 89$ protective effects of the diabetic-safe sweetener erythritol

Chapter $7 \quad$ Potential anti-angiogenic effects of erythritol

Chapter $8 \quad$ Erythritol protects HIT-T15 cells from high glucose induced damage

Chapter $9 \quad$ Oxidative stress markers and cytokine levels in plasma from type 2 diabetics before and after 4 weeks erythritol consumption

Chapter 10 Summary and general discussion

Nederlandse samenvatting 159

Valorization addendum

Dankwoord

Curriculum Vitae

List of publications 

Chapter 1

\section{General introduction}

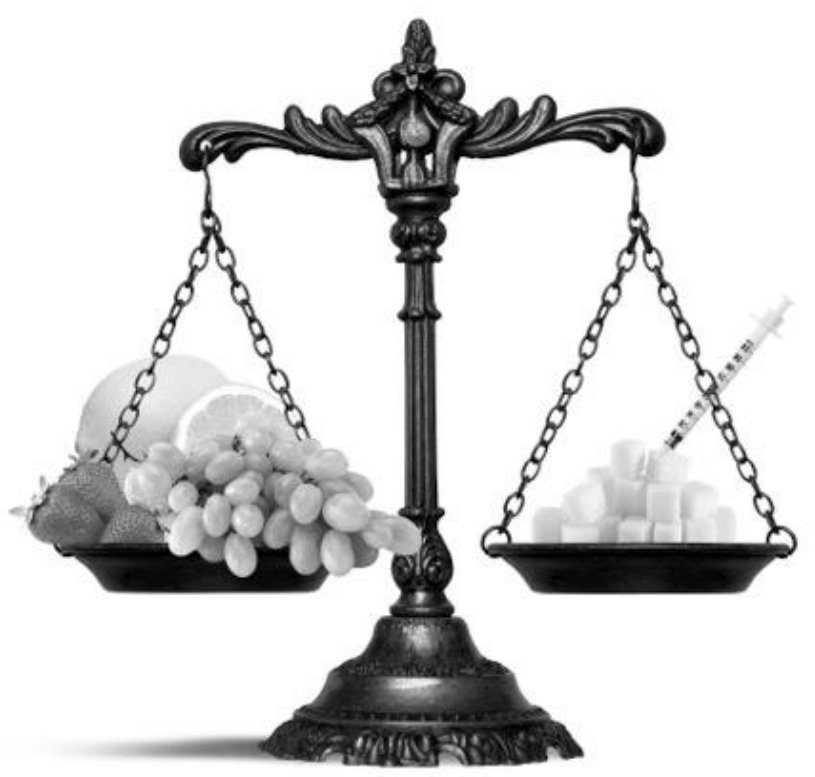




\section{Glucose homeostasis}

The monosaccharide glucose is an important energy source of all mammalian cells. It is obtained from the diet, mainly through starch from consumed plants. When cellular energy reserves run low, glucose is degraded by the glycolysis pathway to generate energy. When glucose is not required for immediate energy production it can be stored in the form of glycogen in animal cells (1).

In healthy individuals, glucose levels are tightly regulated by the body. Normal fasting blood glucose levels range between $4-8 \mathrm{mM}$, with fluctuations throughout the day (2). Glucose homeostasis requires a balance between glucose use, uptake, storage and excretion and is therefore a multi-organ process. Regulation of blood glucose levels depends primarily on two hormones secreted by the endocrine cells of the pancreas: insulin and glucagon (figure 1). In a fed state (i.e. after a meal), insulin dominates and it stimulates glucose uptake from the blood by target organs (e.g. muscle) and glycogen formation by the liver to store excess glucose. In a fasted state, glucagon dominates and this hormone stimulates the liver to breakdown glycogen to synthesize glucose for release into the blood to prevent hypoglycemia (too low plasma glucose concentration) (3). Disruption of glucose metabolism can lead to low blood glucose levels (hypoglycemia) or high blood glucose levels (hyperglycemia).

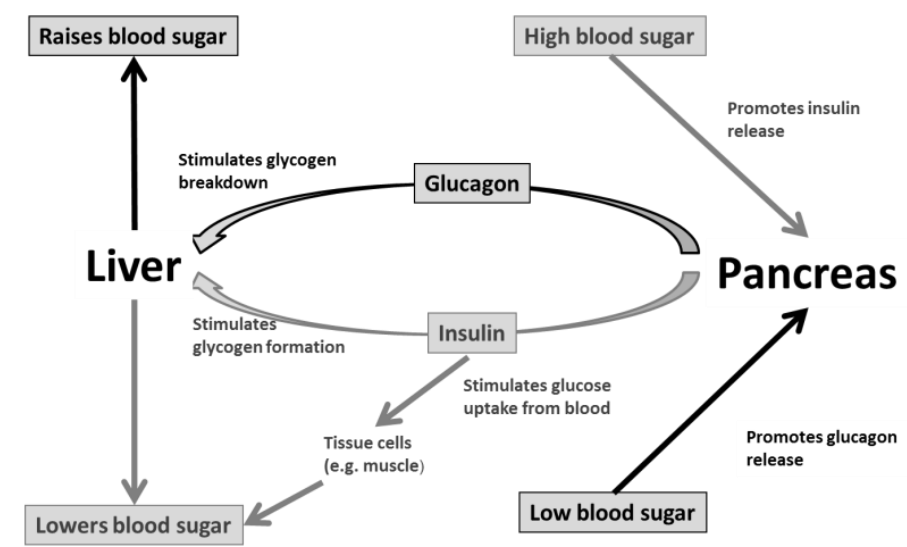

Figure 1: Regulation of blood glucose levels by two pancreatic hormones: insulin and glucose. After a meal glucose levels rise, this stimulates the pancreas to secrete insulin into the blood. Insulin than stimulates the uptake of glucose from the blood by tissue cells and it also stimulates the liver to store the glucose in the form of glycogen. When glucose levels are low, the pancreas secretes glucagon, which has the opposite effects of insulin. Glucagon promotes the breakdown of glycogen and the release of glucose in the blood. Adapted from (4). 


\section{Diabetes mellitus}

Diabetes mellitus represents a heterogeneous group of disorders that have hyperglycemia as a common feature. Diabetes is one of the most prevailing chronic diseases. Worldwide, there are 382 million people with diabetes, and this number is expected to rise to 592 million by 2035 due to the rapid increase in the incidence of the disease caused by population growth, aging, urbanization and increasing prevalence of obesity and physical inactivity (4).

Non-diabetic hyperglycemia which does not meet the criteria set for diabetes is known as prediabetes (5). Metabolic abnormalities that precede diabetes are impaired fasting glucose (IFG) and impaired glucose tolerance (IGT) (table 1). Progression of this prediabetic state to diabetes can take many years, but up to $70 \%$ of patients with these symptoms eventually develops diabetes (6).

Table 1: Diagnostic criteria for diabetes and intermediate hyperglycemia according to the 2006 WHO recommendations (7). 2 hour glucose: venous plasma glucose $2-\mathrm{h}$ after ingestion of $75 \mathrm{~g}$ oral glucose load

\begin{tabular}{|ll|}
\hline Diabetes & \\
\hline Fasting plasma glucose & $\begin{array}{l}\geq 7.0 \mathrm{mmol} / \mathrm{I} \\
\text { or } \\
2 \text { hour plasma glucose }\end{array}$ \\
& $\geq 11.1 \mathrm{mmol} / \mathrm{I}$ \\
\hline Impaired glucose tolerance (IGT) & $<7.0 \mathrm{mmol} / \mathrm{I}$ \\
\hline Fasting plasma glucose & and \\
& $\geq 7.8$ and $<11.1 \mathrm{mmol} / \mathrm{I}$ \\
2 hour plasma glucose & \\
\hline Impaired fasting glucose (IFG) & 6.1 to $6.9 \mathrm{mmol} / \mathrm{l}$ \\
Fasting plasma glucose & and (if measured) \\
& $<7.8 \mathrm{mmol} / \mathrm{l}$ \\
\hline
\end{tabular}

The main types of diabetes are type 1 and type 2 . Type 1 is caused by an autoimmune destruction of beta cells, the insulin producing cells in the pancreas (4). Generally, $90-95 \%$ of diabetes is type 2 , which is historically regarded as a disease of the elderly. Although this age group still has a high risk of developing diabetes, onset of the disease in persons under 30 years of age and even in children and adolescents is increasing $(8 ; 9)$. While type 1 is characterized by an absolute deficiency of insulin secretion, type 2 is characterized by an inability of peripheral tissues to respond to insulin (insulin resistance) and/or defects in insulin secretion (beta cell dysfunction) (4). Other specific types of diabetes can be caused by genetic defects of the beta cell or in insulin action. Also diseases of the pancreas, 


\section{Chapter 1}

drugs, chemicals and infections can induce diabetes (e.g. by impairing insulin secretion) (10).

\section{Beta cells}

Beta cells reside in the pancreas in clusters known as the islets of Langerhans. They are adapted to sense blood glucose levels and can adjust insulin secretion accordingly (11). Their main function is to release insulin in response to increased blood glucose levels.

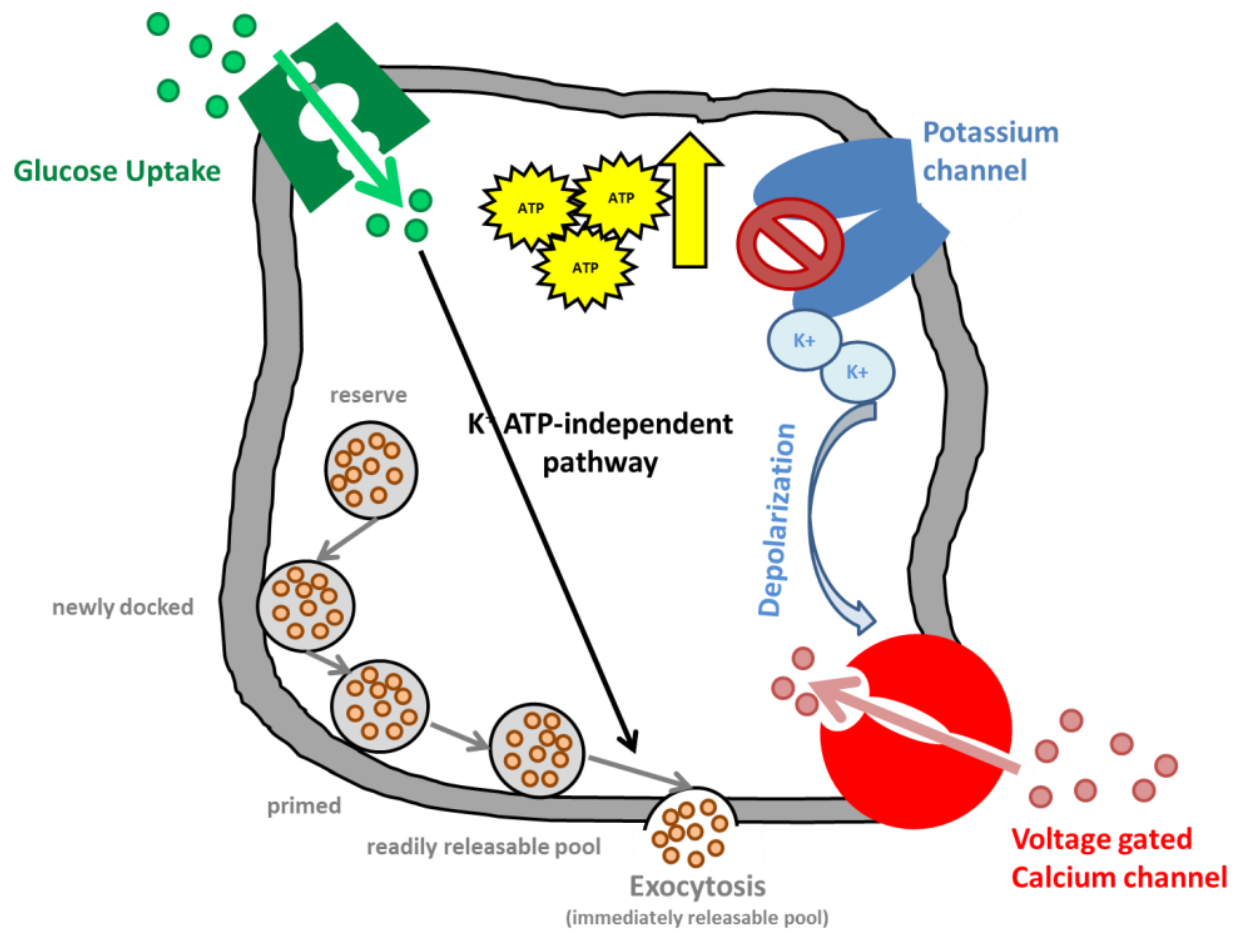

Figure 2: $\mathrm{K}^{+} \mathrm{ATP}$-dependent (triggering) and $\mathrm{K}^{+} \mathrm{ATP}$-independent (augmentation) pathways involved in glucose induced insulin secretion. Glucose metabolism leads to ATP production which triggers closure of the $\mathrm{K}^{+}$ATP (potassium) channel. The cell depolarizes which opens voltage gated calcium channels and the increase in calcium concentration stimulates insulin release. The rate of calcium-stimulated insulin release is augmented by the $\mathrm{K}^{+} \mathrm{ATP}$ independent pathway. Adapted from (14) and (16).

Insulin release occurs as a biphasic process involving different pools of insulin granules. In the first phase glucose enters the beta cell through GLUT-2 transporters. When more glucose is available as a substrate, ATP production increases leading to an elevated cytosolic ATP/ADP ratio. This triggers closure of 
ATP-gated $\mathrm{K}^{+}$channels, causing plasma membrane depolarization, and opening of voltage-gated $\mathrm{Ca}^{2+}$ channels, followed by a rise in cytosolic $\mathrm{Ca}^{2+}$ signals which initiates insulin granule exocytosis (3). The second phase of glucose-stimulated insulin release does not involve a further increase in $\mathrm{Ca}^{2+}$ concentration. Instead it to increase the effect of $\mathrm{Ca}^{2+}$ on exocytosis of insulin granules through biochemical mechanisms that are not yet fully uncovered (12).

The amount of insulin granules present in beta cells is much higher than the number required to be released after a meal. The granules are present in the cytosol (reserve granules) or docked at the plasma membrane. The docked granules are either primed (ready for release) or unprimed (incapable of being released). Primed granules can be further subdivided into readily releasable and immediately releasable, with the latter having the lowest threshold for release. Granules in the immediately releasable pool will undergo exocytosis in response to glucose stimulation $(13 ; 14)$. The remaining granules are responsible for the second phase of insulin release. The conversion of the readily releasable granules to the immediately releasable state is therefore the rate-limiting step of the second phase (15). Pathways and granule pool involved in glucose induced insulin secretion are shown in figure 2.

When the need for insulin secretion is higher than normal (e.g. during hyperglycemia), an increased beta cell glucose sensitivity occurs as a compensatory mechanism (figure 3). This leads to hypersecretion of insulin (i.e. more insulin is secreted than normally would be expected for the level of glycemia). Continuous overstimulation of the beta cells will eventually lead to a depletion of insulin stores, subsequently leading to a reduced insulin secretion and a deterioration of beta cell function $(13 ; 17)$. In diabetic patients this can be seen as a blunted first phase response $(18 ; 19)$. Supraphysiological glucose concentrations $(10-30 \mathrm{mM})$ can cause potentially irreversible beta cell damage and can be deleterious for beta cell function and survival. This concept is called glucotoxicity (20). Glucotoxicity leads to a vicious cycle in which hyperglycemia is worsened by beta cell failure. Persisting hyperglycemia can ultimately lead to serious diabetic complications. 


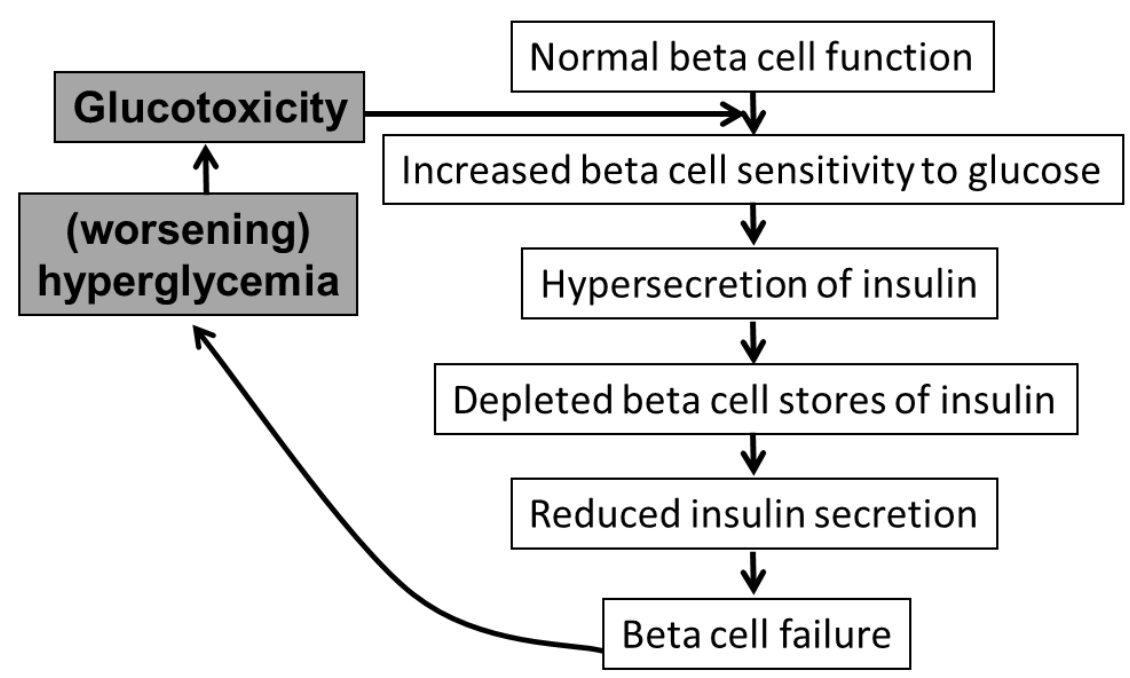

Figure 3: Hyperglycemia leads to beta cell failure which perpetuates hyperglycemia in a vicious cycle. Adapted from (13).

\section{Diabetic complications}

Diabetic patients are at risk of developing a number of disabling and lifethreatening health problems. Several epidemiological studies have shown a relationship between hyperglycemia and an increased risk of cardiovascular diseases, including microvascular pathologies in the eye, kidney and peripheral nerves. As a consequence, diabetes is a leading cause of blindness, renal disease and a variety of debilitating neuropathies (e.g. diabetic foot) $(4 ; 21)$.

Most of these diabetic complications find their origin in damaging of the endothelium, a thin layer of cells lining the cardiovascular system (22-24). Though the endothelium was regarded as a passive barrier for years, it is now known that endothelial cells plays an important role in numerous physiological functions including regulation of blood pressure, blood vessel growth and regulation of permeability. An important endothelium-derived mediator is nitric oxide (NO). NO is a soluble gaseous radical continuously produced by the enzyme nitric oxide synthase (NOS) from L-arginine. NO can then diffuse into vascular smooth muscle cells that line small blood vessels. Here it can bind to and activate the enzyme guanylyl cyclase which results in the formation of cyclic guanosine monophosphate (cGMP). cGMP then activates kinases responsible for vascular relaxation $(25 ; 26)$. Endothelium dependent vasorelaxation is shown in figure 4. Endothelial dysfunction (ED) occurs when the endothelium loses its physiological properties. ED has been linked to diabetes through demonstration of impaired endothelialdependent vasodilation (26). 


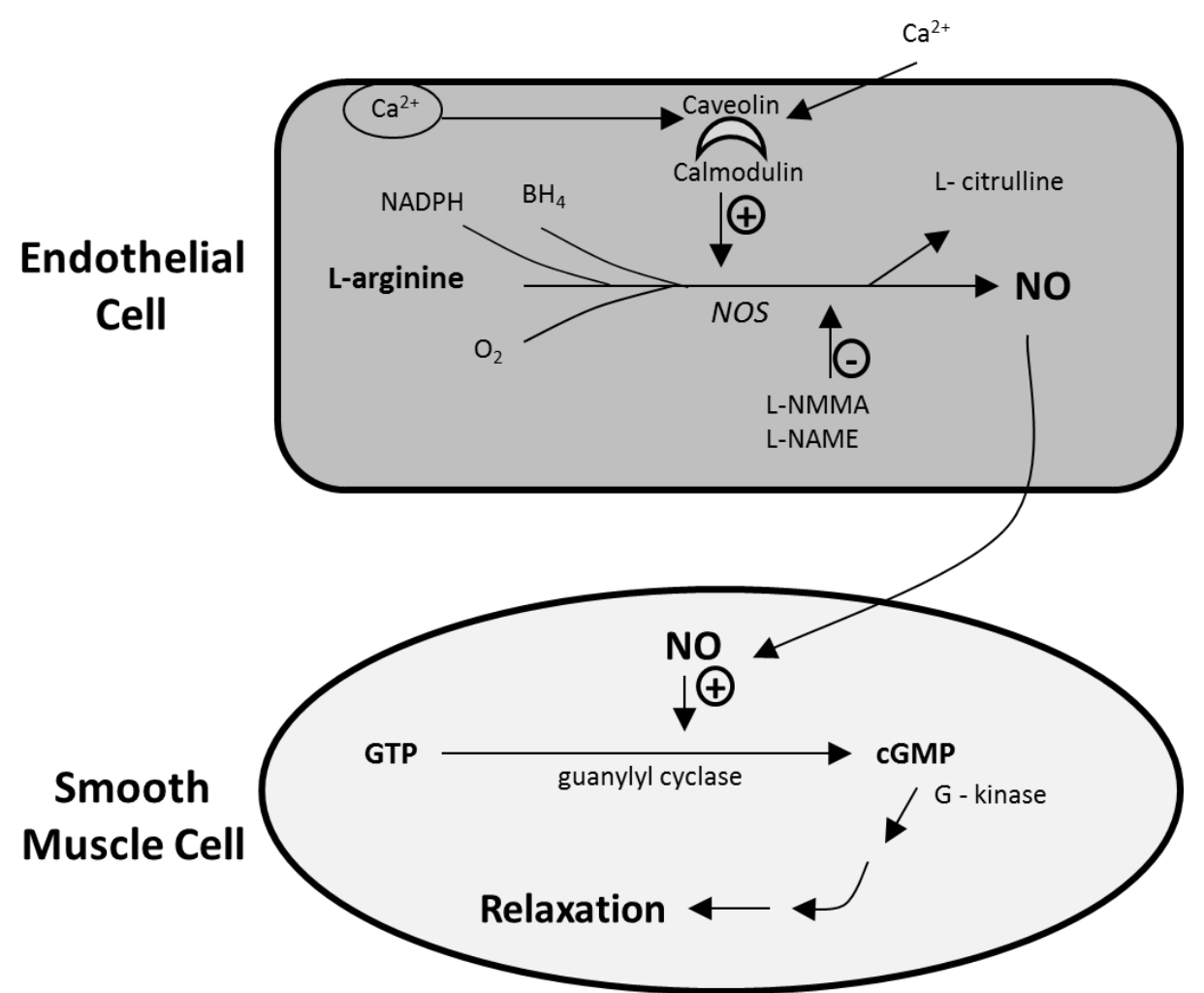

Figure 4: Endothelium dependent vascular relaxation. Increased intracellular calcium (e.g. by stimulation of muscarinic receptors) activates nitric oxide synthase (NOS) through calmodulin (by displacement of its inhibitor caveolin). NO is then produced from L-arginine, which requires a number of cofactors, including tetrahydrobiopterin $\left(\mathrm{BH}_{4}\right)$ and nicotinamide adenine dinucleotide phosphate (NADPH). NO diffuses to the smooth muscle cells where it initiates relaxation through activation of guanylyl cyclase. L-NMMA and L-NAME are inhibitors of NOS. Adapted from (27) and (28).

\section{Molecular mechanisms of diabetic complications}

The initiation of diabetic tissue damage can be influenced by genetic predisposition of individual susceptibility and by independent accelerating factors (e.g. hypertension). Moreover, various mechanisms that explain how hyperglycemia directly causes vascular complications have been described (29). These include activation of the protein kinase $C$ (PKC) pathway, increased hexosamine pathway flux, increased flux through the polyol pathway and increased formation of advanced glycation end products (AGEs). The latter two pathways will be described in more detail as they are subject of this thesis. 


\section{Polyol pathway}

In tissues that do not require insulin for glucose transport (e.g. nerves, lens, kidney), hyperglycemia can lead to an increase in the intracellular glucose. This activates the polyol pathway (figure 5) (30). During normoglycemia only 3\% of all glucose will enter the polyol pathway. Most of the glucose will be phosphorylated to glucose-6-phosphate by hexokinase. However, under hyperglycemic conditions this increases to $30 \%$, mainly due to a saturation of hexokinase $(31 ; 32)$. Aldose reductase, the first and rate-limiting enzyme in the pathway, reduces glucose to sorbitol using NADPH as a cofactor. Then, sorbitol is reduced to fructose by sorbitol dehydrogenase which uses $\mathrm{NAD}^{+}$as a cofactor. The accumulated sorbitol and fructose lead to increased intracellular osmolarity and influx of water, which will eventually lead to osmotic cell injury. For example, in the lens this can lead to swelling and opacity, resulting in cataractogenesis. Redox imbalance following the depletion of NADPH and $\mathrm{NAD}^{+}$further contributes to cell damage and organ injury (33-35). A decrease in NADPH levels can lead to a deficiency in reduced glutathione (GSH), which could induce or worsen intracellular oxidative stress. Additionally, $\mathrm{NAD}^{+}$depletion limits the activity of the enzyme glyceraldehyde-3-phosphate dehydrogenase (GAPDH), which results in increased amounts of triose phosphates. As a result, triose phosphate can increase the formation of methylglyoxal (precursor of AGEs) and diacylglycerol (DAG; a potent PKC activator) (29).

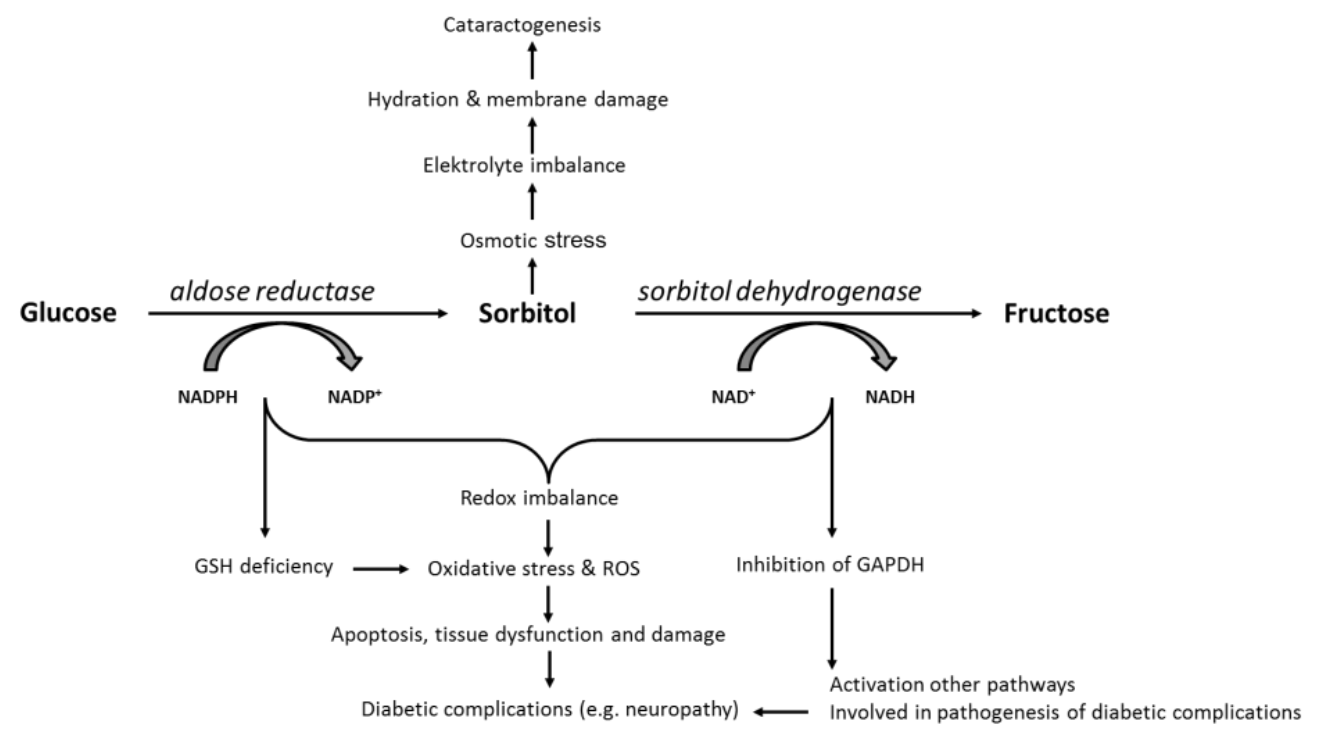

Figure 5: Hyperglycemia increases glucose flux through the polyol pathway. This pathway can lead to diabetic complications via accumulation of sorbitol, redox imbalance and depletion of NADPH and $\mathrm{NAD}^{+}$. Adapted from (35). 


\section{Increased intracellular formation of advanced glycation end-products}

Formation of advanced glycation end products (AGEs) leads to increased formation of oxygen radicals. AGEs constitute a heterogeneous group of macromolecules formed by the nonenzymatic glycation of proteins, lipids and nucleic acids. AGEs can be ingested with food and are also formed in small amounts endogenously in the body as a consequence of normal metabolism (36). AGEs have a number of chemical and biological properties that are potentially pathogenic. AGEs can contribute to diabetic complication by the formation of crosslinks in the basal membrane and accumulation of glycated proteins which alter cellular structure and protein function. For example, AGEs can affect the structure and function of capillaries which then develop thickened basement membranes and become leaky. In addition, AGEs can interact with the receptor for AGEs (RAGE). This interaction induces oxidative stress and subsequently the release of pro-inflammatory cytokines and growth factors that contribute towards the pathology of diabetic complications $(29 ; 37 ; 38)$.

\section{Oxidative stress}

When there is an imbalance between the cellular antioxidant capacity and the production of reactive oxygen species (ROS), oxidative stress occurs (39). Oxidative stress also plays a pivotal role in the development of diabetic complications (40).

ROS such as superoxide anion $\left(\mathrm{O}_{2}{ }^{--}\right)$, hydrogen peroxide $\left(\mathrm{H}_{2} \mathrm{O}_{2}\right)$ and hydroxyl radical $(\mathrm{HO} \bullet)$ are molecules derived from oxygen. They are generated endogenously through multiple mechanisms (e.g. during mitochondrial oxidative phosphorylation). Additionally, they can be formed from interactions with exogenous sources such as smoke, xenobiotics or radiation (39). ROS have an important role in cellular signalling and in a variety of cellular processes. They can interact with critical signalling molecules (i.e. cause post-translational protein modification such as oxidizing thiol groups), and thereby change the activity and alter the function of the target protein (41). For example, hydrogen peroxide is known to be one of the metabolic signals for insulin secretion (42).

Physiological levels of ROS are tightly controlled by enzymatic and non-enzymatic antioxidants. Enzymatic oxidants include superoxide dismutase (SOD) is the first line of defense against superoxide. Three distinct forms are present in eukaryotes which all contain metals required for their enzyme activity. The cytosolic form contains copper or zinc ions (Cu/Zn-SOD or SOD1), the mitochondrial form contains manganese ions (Mn-SOD or SOD2) and the extracellular form also contains copper and zinc ions (EC-SOD or SOD3) (43). SODs catalyze the dismutation of superoxide 
to $\mathrm{H}_{2} \mathrm{O}_{2}$ and oxygen. $\mathrm{H}_{2} \mathrm{O}_{2}$ can subsequently be degraded by catalase into water and oxygen (44) or into water by glutathione peroxidase by oxidizing reduced glutathione (GSH) to GSSG (45). Non-enzymatic endogenous antioxidants are amongst others alpha-lipoic acid, ascorbic acid (vitamin C) and vitamin E (46; 47)

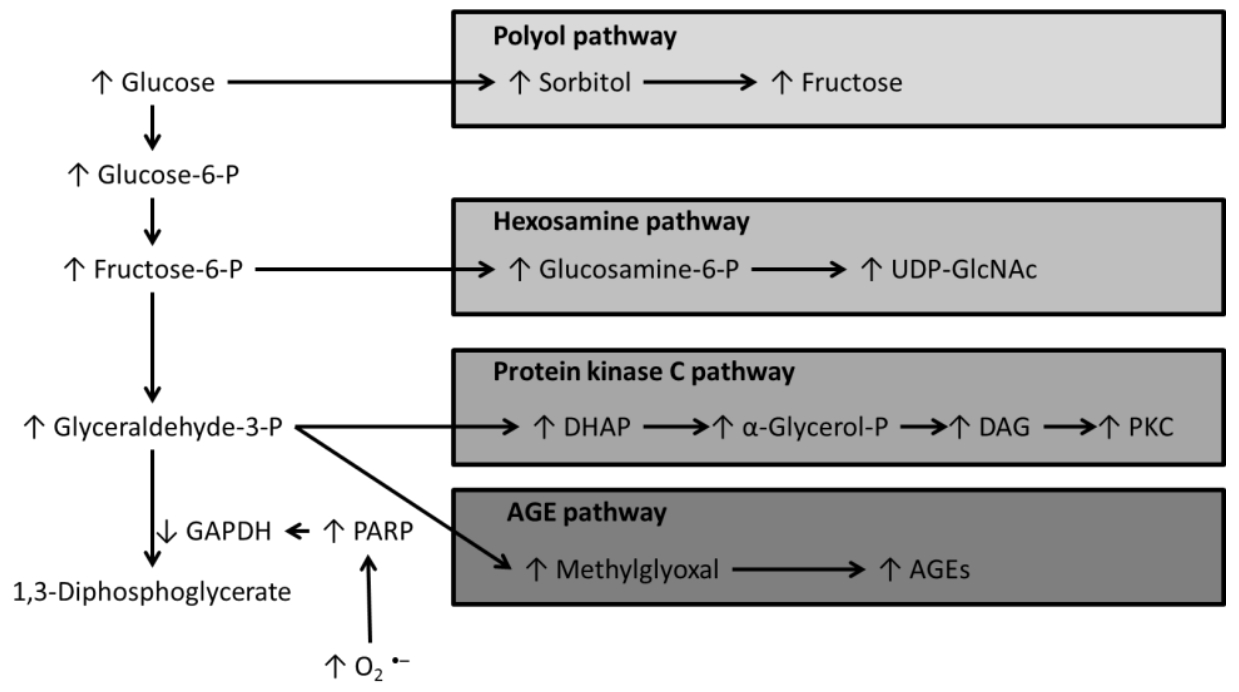

Figure 6: Molecular mechanisms underlying hyperglycemia-induced damage. Mitochondrial superoxide overproduction activates PARP which in turn leads to a decrease in GAPDH activity. Subsequently four pathways of hyperglycemia-induced damage are activated due to accumulation of glycolytic intermediates upstream of GAPDH: the polyol pathway, the hexosamine pathway, the PKC pathway and the AGE pathway. Adapted from (49).

During disease or infection, antioxidant systems can get overwhelmed with ROS. This can result in damage of nucleic acids (e.g. 8-Oxoguanine), proteins (e.g. protein carbonylation) and lipids (e.g. lipid peroxidation) (39). Activation of the previously mentioned pathways arises from hyperglycemia-induced overproduction of superoxide by the mitochondrial electron transport chain (29). Electron transport occurs in the inner mitochondrial membrane via coupled redox reactions. It is responsible for generation of ATP by oxidizing reduced co-enzymes generated in the tricarboxylic acid (TCA) cycle, fatty acid oxidation and amino acid oxidation. Under normal circumstances a small percentage of electrons leak out (mainly at complex I and III) and react with oxygen to form superoxide (48). During hyperglycemia, more glucose is being oxidized in the glycolysis and TCA cycle which increases the flux of electron donors ( $\mathrm{NADH}$ and $\mathrm{FADH}_{2}$ ) into the electron transport chain, ultimately leading to an increase in superoxide generation (49). The overproduction of superoxide induces DNA strand breaks, by which the enzyme 
poly(ADP-ribose) polymerase (PARP) is activated. PARP can detect and signal DNA strand breaks. Upon detection, PARP binds to the DNA and synthesizes a poly(ADPribose) (PAR) chain as a signal for DNA repair enzymes. $N A D^{+}$is required as a substrate for the synthesis of these PAR monomers (50). PAR polymers can accumulate on GAPDH, thereby decreasing its activity and subsequently cause an accumulation of glycolytic intermediates upstream of GAPDH (40;49). Decreased GAPDH activity can than lead to an activation of the polyol (because of high intracellular levels of glucose), PKC (due to an increase of DAG) and hexosamine (by an increase of fructose- 6 phosphate) pathway and an increase in the formation of intracellular AGEs (by increased formation of the AGE precursor methylglyoxal) (49). An overview of the molecular mechanisms of hyperglycemia induced diabetic complications is shown in figure 6.

\section{Current treatment of diabetes}

Treatment goals for patients with diabetes are focused on control of hyperglycemia (51). This can be achieved through lifestyle changes (e.g. increase in physical activity) and pharmacological intervention. Control of blood glucose levels can delay the progression to type 2 diabetes in people with IGT (52). The main pharmacological treatments are focused on elevating insulin levels, improvement of insulin sensitivity and reducing the rate at which glucose is absorbed from the gastrointestinal tract (53). The mechanisms of action of all classes will be briefly discussed below and are summarized in figure 7.

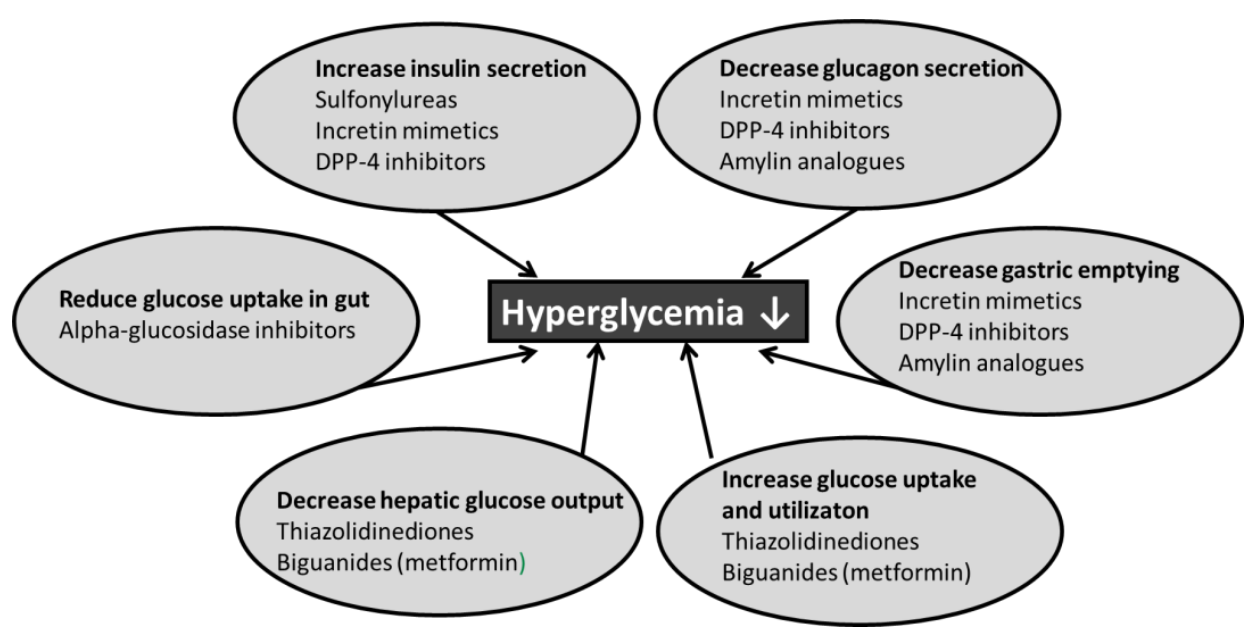

Figure 7: Overview of the working mechanisms of the most used pharmacological diabetic treatments. 


\section{Drugs that increase insulin levels - Secretagogues}

This group includes insulin, sulfonylureas, incretin mimetics and dipeptidyl peptidase 4 (DPP-4) inhibitors. Since its first use as a treatment in 1922 by the Canadians Frederick Banting and Charles Best, exogenous insulin remains an important part of diabetes treatment and is indeed lifesaving for type 1 patients (54). Chronic insulin therapy in type 2 diabetes is mostly used in the later stages when other medications have failed to control blood glucose levels (55). Sulfonylureas act on beta cells to increase insulin release. They close the $\mathrm{K}^{+} \mathrm{ATP}$ channel by binding to the SUR subunit. This ultimately triggers a rise in intracellular $\mathrm{Ca}^{2+}$ concentration, which stimulates insulin release (56). Incretin mimetics and DPP-4 inhibitors are relatively new therapies, which use the properties of the incretin hormones glucagon-like peptide 1 (GLP-1) and gastric inhibitory peptide (GIP). These are gut-derived hormones that bind to specific G-protein-coupled receptors present on beta cells. Upon activation of the receptor, adenylate cyclase is activated, inducing the production of AMP which ultimately triggers insulin synthesis and secretion and inhibits glucagon release. In addition to their insulinotropic effect, incretins also slow down gastric emptying (GLP-1) and regulate appetite by enhancing satiety (57). Incretin mimetics are GLP-1 receptor agonists. DPP-4 inhibitors (also called incretin enhancers) prolong the activity of incretins by inhibiting their proteolytic degradation and inactivation by DPP-4 (58).

\section{Drugs that increase insulin sensitivity - Sensitizers}

This group includes thiazolidinediones (TZDs) and biguanides. TZDs are also known as glitazones. They improve insulin action by activating peroxisome proliferatoractivated receptor- $\nu$ (PPAR- $\gamma$ ) nuclear receptors in tissues such as adipose, skeletal muscle and liver. Activation of these receptors modulates transcription genes involved in the control of glucose and lipid metabolism (59). Biguanides decrease hepatic glucose output. Metformin is the only biguanide currently used in the treatment of diabetes. The molecular mechanisms by which metformin decreases hepatic gluconeogenesis are debated. Metformin appears to accumulate in the mitochondria where it induces a mild and specific inhibition of the respiratorychain complex 1 . This results in a decrease of ATP production, which in turn activates the proposed molecular target of metformin, AMP-activated protein kinase (AMPK). AMPK inhibits energy consuming processes (e.g. glucose, lipid and protein synthesis) and switches the metabolism of the cell toward energy production $(60 ; 61)$. 


\section{Drugs that reduce postpranial glucose absorption}

This group includes alpha-glucosidase inhibitors and amylin analogues. Alphaglucosidases break down starch and disaccharides to glucose. By inhibiting these enzymes the absorption of glucose from the gut is delayed (62). Amylin is a peptide hormone that is co-secreted with insulin from the beta cell. Amylin analogues mimic the functions of amylin by inhibiting glucagon release and slow down gastric emptying (63).

\section{Natural compounds as treatments against diabetes}

Besides the conventional pharmacological treatments, natural compounds are also being studied as treatments against diabetes. More than 400 proven medicinal plants exhibit antidiabetic properties, but from only about $25 \%$ the mechanism of action is known (64). An example of a medicinal plant with hypoglycemic activities is ginseng. Ginseng is known to increase insulin sensitivity although the efficacy and potency depends on the species that is used (65). Furthermore, the dietary spice cinnamon reduced serum glucose in people with type 2 diabetes (66). The mechanism of action is not yet known, although cinnamon extracts inhibit alphaglucosidase activity (67). Also herbs used as traditional medicine possess antidiabetic properties (68). Another well studied natural compound which has been reported to have beneficial effects in diabetes is alpha-lipoic acid. Due to its role as an antioxidant it can decelerate the development of diabetic complications. Furthermore, it has been shown to increase insulin sensitivity by increasing glucose uptake and utilization (69).

\section{Polyphenols and diabetes}

Since oxidative stress plays a central role in the pathogenesis of diabetic complications, therapies focusing on antioxidant effects might be of interest. Polyphenols are the most abundant antioxidants in the diet. They are compounds found in plant-based foods (fruits, vegetables, whole grains, cereals, legumes) and plant-derived beverages (fruit juices, tea, coffee and red wine) (70). Beneficial effects of polyphenols on blood glucose management, based on in vitro studies, animal models and some clinical trials, are shown in figure 8 . These effects are mainly attributed to a reduction of intestinal glucose uptake, improvement of beta cell function and insulin action, regulation of carbohydrate metabolism and improvement of insulin uptake (71). 


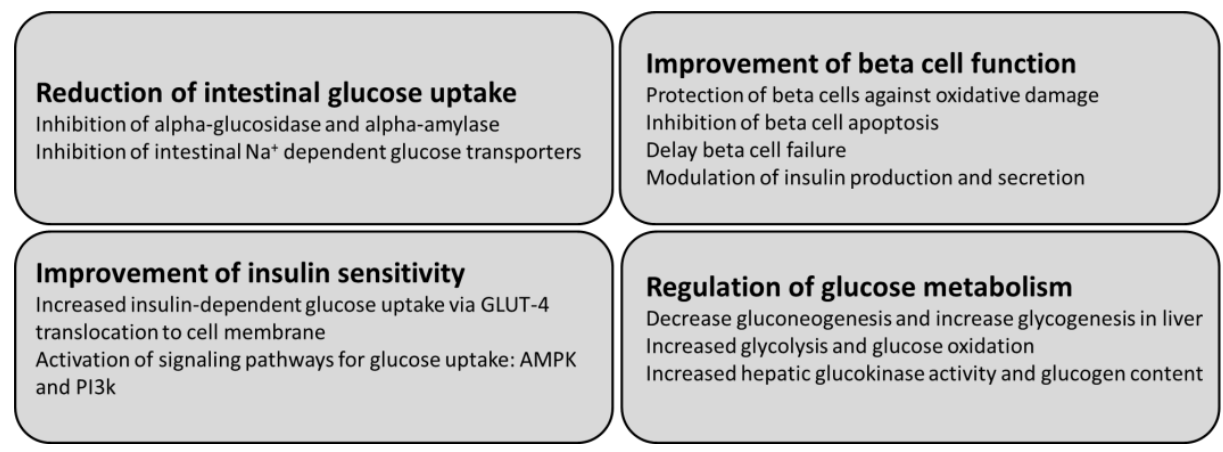

Figure 8: Mechanisms by which polyphenols can improve glucose homeostasis. Adapted from (71).

Of the polyphenols, flavonoids are the most abundant in the human diet, with more than 4000 types identified in a wide range of dietary sources like berries, soybeans and onions (71). The total consumption of dietary flavonoids is estimated at several hundred milligrams per day with Mediterranean populations (e.g. Spanish) showing a higher intake than non-Mediterranean populations (72). Flavonoids intake has been linked to a reduced risk for various diseases, including diabetes (73). The antioxidant and anti-inflammatory activity of flavonoids along with their other properties (e.g. inhibition of alpha- glucosidase) make them promising candidates for the management of hyperglycemia, alone or in combination with established antidiabetic treatments. 


\section{Aim and outline of the thesis}

The overall aim of this thesis was to investigate the potential mechanisms by which natural compounds could help to attenuate or delay the onset of diabetic complications. The first chapters focus on mechanisms of protection by polyphenols. However since it is known that polyphenols can also exert pro-oxidant activities, we also studied the protective mechanism of a polyol compound. This is discussed in chapters $5-8$.

In chapter 2 the role of PARP is investigated in a chronic oxidative stress model. In this model we use the polyphenol fisetin and the antibiotic minocycline to inhibit PARP activity.

In chapter 3 the effects on redox state of endothelial cells under hyperglycemic conditions is investigated. In this study we used the polyphenols flavone, rutin and quercetin to investigate their protective role on $\mathrm{NAD}^{+}$levels.

In chapter 4 the effects of the AGE $\mathrm{N}^{\varepsilon}$-carboxymethyllysine on the glutathione system of a human beta cell line is investigated.

In chapter 5 a review about the health effects of the polyol erythritol is given

In chapter 6 the endothelial protective effects of erythritol are investigated in an endothelial cell line using targeted and transcriptomic approaches.

In chapter 7 the effects of erythritol on endothelial cells is further investigated with a focus on anti-angiogenic mechanisms.

In chapter 8 the possible influence of erythritol on beta cell dysfunction is investigated in a hamster beta cell line

In chapter 9 antioxidant and inflammatory markers are measured in a pilot study on the effects of erythritol in patients with type 2 diabetes

In chapter 10 the most important findings are discussed and the future perspectives are given. 


\section{References}

1. Szablewski L: Glucose and Lipid Metabolism In Glucose Homeostasis and Insulin Resistance, Bentham Science Publishers Ltd., 2011, p. 1-21

2. Wat zijn normale bloedsuikerwaarden? [article online], Available from http://www.diabetesfonds.nl/faq/wat-zijn-normale-bloedsuikerwaarden.

3. Silverthorn DU: Metabolism and Energy Balance. In Human Physiology, Pearson Education, Inc., 2004, p. 695-725

4. IDF Diabetes Atlas, 6th edn. [article online], 2013. Available from http://www.idf.org/diabetesatlas.

5. Rhee SY, Woo JT: The prediabetic period: review of clinical aspects. Diabetes Metab J 2011;35:107-116

6. Nathan DM, Davidson MB, DeFronzo RA, Heine RJ, Henry RR, Pratley R, Zinman B: Impaired Fasting Glucose and Impaired Glucose Tolerance: Implications for care. Diabetes Care 2007;30:753-759

7. World Health Organization. Definition and diagnosis of diabetes mellitus and intermediate hyperglycemia. Report of a WHO/IDF Consultation. Geneva (Switzerland) 2006

8. Venkat Narayan KM, Gregg EW, Fagot-Campagna A, Engelgau MM, Vinicor F: Diabetes - a common, growing, serious, costly, and potentially preventable public health problem.

Diabetes Research and Clinical Practice 2000;50, Supplement 2:S77-S84

9. Alberti G, Zimmet P, Shaw J, Bloomgarden Z, Kaufman F, Silink M: Type 2 Diabetes in the Young: The Evolving Epidemic: The International Diabetes Federation Consensus Workshop. Diabetes Care 2004;27:1798-1811

10. Diagnosis and Classification of Diabetes Mellitus. Diabetes Care 2004;27:s5-s10

11. Fridlyand L, Philipson L: Glucose sensing in the pancreatic beta cell: a computational systems analysis. Theoretical Biology and Medical Modelling 2010;7:15

12. Henquin J-C, Ishiyama N, Nenquin M, Ravier MA, Jonas J-C: Signals and Pools Underlying Biphasic Insulin Secretion. Diabetes 2002;51:S60-S67

13. Leahy LJ: Detrimental Effects of Chronic Hyperglycemia on the Pancreatic $\beta$-Cell. In Diabetes Mellitus: A Fundamental and Clinical Text LeRoith D, Taylor SI, Olefsky JM, Eds. Philadelphia, Lippincott Williams \& Wilkins, 2004, p. 115 - 127

14. Straub SG, Sharp GWG: Hypothesis: one rate-limiting step controls the magnitude of both phases of glucose-stimulated insulin secretion. American Journal of Physiology - Cell Physiology 2004;287:C565-C571

15. Straub SG, Sharp GW: Glucose-stimulated signaling pathways in biphasic insulin secretion. Diabetes Metab Res Rev 2002;18:451-463

16. Insulin - from secretion to action [article online], Available from http://www.betacell.org/content/articleview/article_id/1/page/1/glossary/0/.

17. Poitout V, Robertson RP: Glucolipotoxicity: Fuel Excess and $\beta$-Cell Dysfunction. Endocrine Reviews 2008;29:351-366

18. Del Prato S, Marchetti P, Bonadonna RC: Phasic Insulin Release and Metabolic Regulation in Type 2 Diabetes. Diabetes 2002;51:S109-S116

19. Gerich JE: Is Reduced First-Phase Insulin Release the Earliest Detectable Abnormality in Individuals Destined to Develop Type 2 Diabetes? Diabetes 2002;51:S117-S121

20. Bensellam M, Laybutt DR, Jonas J-C: The molecular mechanisms of pancreatic $\beta$-cell glucotoxicity: Recent findings and future research directions. Molecular and Cellular Endocrinology 2012;364:1-27

21. Aronson D: Hyperglycemia and the pathobiology of diabetic complications. Adv Cardiol 2008;45:1-16 
22. Furchgott RF, Jothianandan D: Endothelium-Dependent and -Independent Vasodilation Involving Cyclic GMP: Relaxation Induced by Nitric Oxide, Carbon Monoxide and Light. Journal of Vascular Research 1991;28:52-61

23. Grieve DJ, Avella MA, Botham KM, Elliott J: Effects of chylomicrons remnants on endothelium-dependent relaxation of rat aorta. European Journal of Pharmacology 1998;348:181-190

24. Praticò D: Antioxidants and endothelium protection. Atherosclerosis 2005;181:215-224

25. Tousoulis D, Kampoli AM, Tentolouris C, Papageorgiou N, Stefanadis C: The role of nitric oxide on endothelial function. Curr Vasc Pharmacol 2012;10:4-18

26. Roberts AC, Porter KE: Cellular and molecular mechanisms of endothelial dysfunction in diabetes. Diabetes and Vascular Disease Research 2013;

27. Davignon J, Ganz P: Role of Endothelial Dysfunction in Atherosclerosis. Circulation 2004;109:III-27-III-32

28. The Nature of the Endothelium-Derived Relaxing Factor [article online], Available from http://www.downstate.edu/pharmacology/faculty/furchgott.html.

29. Brownlee M: Biochemistry and molecular cell biology of diabetic complications. Nature 2001;414:813-820

30. Gabbay KH: The sorbitol pathway and the complications of diabetes. N Engl J Med 1973;288:831-836

31. Bhatnagar A, Srivastava SK: Aldose reductase: congenial and injurious profiles of an enigmatic enzyme. Biochem Med Metab Biol 1992;48:91-121

32. Yabe-Nishimura C: Aldose reductase in glucose toxicity: a potential target for the prevention of diabetic complications. Pharmacol Rev 1998;50:21-33

33. Oyama T, Miyasita Y, Watanabe H, Shirai K: The role of polyol pathway in high glucoseinduced endothelial cell damages. Diabetes Res Clin Pract 2006;73:227-234

34. Reddy GB, Satyanarayana A, Balakrishna N, Ayyagari R, Padma M, Viswanath K, Petrash

JM: Erythrocyte aldose reductase activity and sorbitol levels in diabetic retinopathy. Mol Vis 2008;14:593-601

35. Srivastava SK, Ramana KV, Bhatnagar A: Role of aldose reductase and oxidative damage in diabetes and the consequent potential for therapeutic options. Endocr Rev 2005;26:380392

36. Semba RD, Nicklett EJ, Ferrucci L: Does Accumulation of Advanced Glycation End Products Contribute to the Aging Phenotype? The Journals of Gerontology Series A: Biological Sciences and Medical Sciences 2010;65A:963-975

37. Ahmed N: Advanced glycation endproducts-role in pathology of diabetic complications. Diabetes Research and Clinical Practice 2005;67:3-21

38. Goldin A, Beckman JA, Schmidt AM, Creager MA: Advanced Glycation End Products: Sparking the Development of Diabetic Vascular Injury. Circulation 2006;114:597-605 39. Ray PD, Huang B-W, Tsuji Y: Reactive oxygen species (ROS) homeostasis and redox regulation in cellular signaling. Cellular Signalling 2012;24:981-990

40. Giacco F, Brownlee M: Oxidative Stress and Diabetic Complications. Circulation Research 2010;107:1058-1070

41. Sena Laura A, Chandel Navdeep S: Physiological Roles of Mitochondrial Reactive Oxygen Species. Molecular Cell 2012;48:158-167

42. Pi J, Bai Y, Zhang Q, Wong V, Floering LM, Daniel K, Reece JM, Deeney JT, Andersen ME, Corkey BE, Collins S: Reactive Oxygen Species as a Signal in Glucose-Stimulated Insulin Secretion. Diabetes 2007;56:1783-1791

43. Fridovich I: Superoxide Anion Radical (0:2), Superoxide Dismutases, and Related Matters. Journal of Biological Chemistry 1997;272:18515-18517 
44. Chelikani P, Fita I, Loewen PC: Diversity of structures and properties among catalases. CMLS, Cell Mol Life Sci 2004;61:192-208

45. Hayes JD, McLellan LI: Glutathione and glutathione-dependent enzymes represent a coordinately regulated defence against oxidative stress. Free Radic Res 1999;31:273-300

46. Rizzo A, Berselli P, Zava S, Montorfano G, Negroni M, Corsetto P, Berra B: Endogenous Antioxidants and Radical Scavengers. In Bio-Farms for Nutraceuticals Giardi M, Rea G, Berra B, Eds., Springer US, 2010, p. 52-67

47. Jacobs H, Moalin M, Bast A, van der Vijgh WJF, Haenen GRMM: An Essential Difference between the Flavonoids MonoHER and Quercetin in Their Interplay with the Endogenous Antioxidant Network. PLoS One 2010;5:e13880

48. Jastroch M, Divakaruni AS, Mookerjee S, Treberg JR, Brand MD: Mitochondrial proton and electron leaks. Essays Biochem 2010;47:53-67

49. Brownlee M: The Pathobiology of Diabetic Complications: A Unifying Mechanism.

Diabetes 2005;54:1615-1625

50. Javle M, Curtin NJ: The role of PARP in DNA repair and its therapeutic exploitation. $\mathrm{Br} J$ Cancer 2011;105:1114-1122

51. Israili ZH: Advances in the Treatment of Type 2 Diabetes Mellitus. American Journal of Therapeutics 2011;18:117-152 110.1097/MJT.1090b1013e3181afbf1051

52. Gillies CL, Abrams KR, Lambert PC, Cooper NJ, Sutton AJ, Hsu RT, Khunti K:

Pharmacological and lifestyle interventions to prevent or delay type 2 diabetes in people with impaired glucose tolerance: systematic review and meta-analysis. BMJ 2007;334:299 53. Verspohl EJ: Novel Pharmacological Approaches to the Treatment of Type 2 Diabetes. Pharmacological Reviews 2012;64:188-237

54. Tibaldi JM: The Future of Insulin Therapy for Patients With Type 2 Diabetes Mellitus. JAOA: Journal of the American Osteopathic Association 2013;113:S29-S39

55. Lebovitz HE: Insulin: Potential Negative Consequences of Early Routine Use in Patients With Type 2 Diabetes. Diabetes Care 2011;34:S225-S230

56. Proks P, Reimann F, Green N, Gribble F, Ashcroft F: Sulfonylurea Stimulation of Insulin Secretion. Diabetes 2002;51:S368-S376

57. Cernea S, Raz I: Therapy in the Early Stage: Incretins. Diabetes Care 2011;34:S264-S271

58. McIntosh CHS, Demuth H-U, Pospisilik JA, Pederson R: Dipeptidyl peptidase IV inhibitors: how do they work as new antidiabetic agents? Regulatory Peptides 2005;128:159-165

59. Kendall DM: Thiazolidinediones: The case for early use. Diabetes Care 2006;29:154-157

60. Viollet B, Guigas B, Sanz Garcia N, Leclerc J, Foretz M, Andreelli F: Cellular and molecular mechanisms of metformin: an overview. Clin Sci (Lond) 2012;122:253-270

61. Pulito C, Sanli T, Rana P, Muti P, Blandino G, Strano S: Metformin: On Ongoing Journey across Diabetes, Cancer Therapy and Prevention. Metabolites 2013;3:1051-1075

62. van de Laar FA: Alpha-glucosidase inhibitors in the early treatment of type 2 diabetes.

Vasc Health Risk Manag 2008;4:1189-1195

63. Adeghate $\mathrm{E}$, Kalasz $\mathrm{H}$ : Amylin analogues in the treatment of diabetes mellitus: medicinal chemistry and structural basis of its function. Open Med Chem J 2011;5:78-81

64. Prabhakar PK, Doble M: A target based therapeutic approach towards diabetes mellitus using medicinal plants. Curr Diabetes Rev 2008;4:291-308

65. Prabhakar P, Doble M: Mechanism of action of natural products used in the treatment of diabetes mellitus. Chin J Integr Med 2011;17:563-574

66. Khan A, Safdar M, Ali Khan MM, Khattak KN, Anderson RA: Cinnamon Improves Glucose and Lipids of People With Type 2 Diabetes. Diabetes Care 2003;26:3215-3218

67. Mohamed Sham Shihabudeen H, Hansi Priscilla D, Thirumurugan K: Cinnamon extract inhibits alpha-glucosidase activity and dampens postprandial glucose excursion in diabetic rats. Nutr Metab (Lond) 2011;8:46 
68. Modak M, Dixit P, Londhe J, Ghaskadbi S, Devasagayam TP: Indian herbs and herbal drugs used for the treatment of diabetes. J Clin Biochem Nutr 2007;40:163-173

69. Poh ZX, Goh KP: A current update on the use of alpha lipoic acid in the management of type 2 diabetes mellitus. Endocr Metab Immune Disord Drug Targets 2009;9:392-398

70. Scalbert A, Johnson IT, Saltmarsh M: Polyphenols: antioxidants and beyond. The American Journal of Clinical Nutrition 2005;81:215S-217S

71. Bahadoran Z, Mirmiran P, Azizi F: Dietary polyphenols as potential nutraceuticals in management of diabetes: a review. J Diabetes Metab Disord 2013;12:43

72. Zamora-Ros R, Andres-Lacueva C, Lamuela-Raventos RM, Berenguer T, Jakszyn $P$,

Barricarte A, Ardanaz E, Amiano P, Dorronsoro M, Larranaga N, Martinez C, Sanchez MJ, Navarro C, Chirlaque MD, Tormo MJ, Quiros JR, Gonzalez CA: Estimation of dietary sources and flavonoid intake in a Spanish adult population (EPIC-Spain). J Am Diet Assoc 2010;110:390-398

73. Wedick NM, Pan A, Cassidy A, Rimm EB, Sampson L, Rosner B, Willett W, Hu FB, Sun Q van Dam RM: Dietary flavonoid intakes and risk of type 2 diabetes in US men and women. Am J Clin Nutr 2012;95:925-933 
Chapter 2

\section{Accelerated aging during chronic oxidative stress: a role for PARP-1}

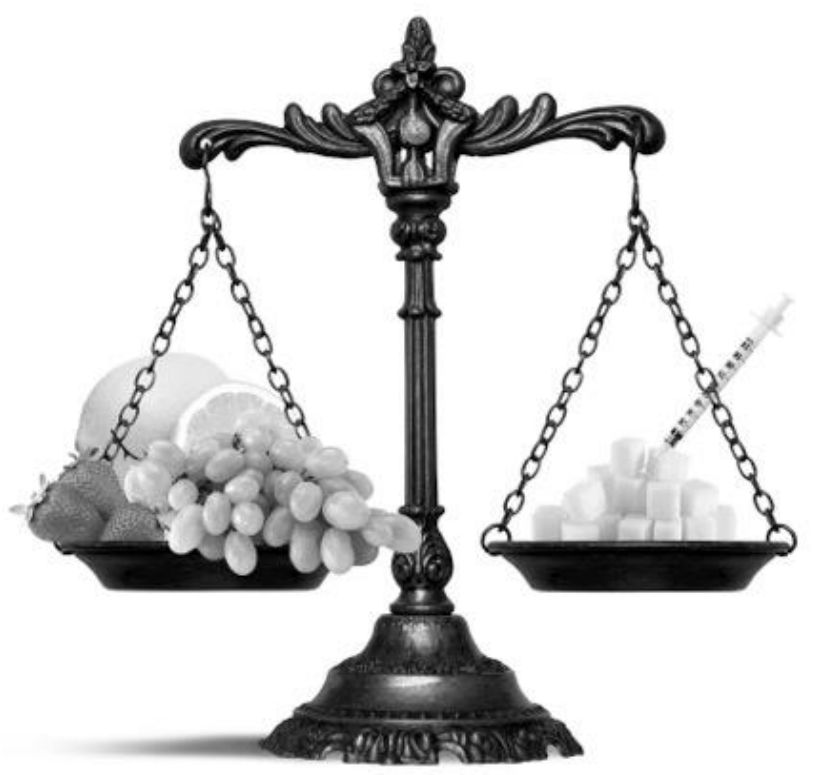

Daniëlle M.P.H.J. Boesten

Joyce M.J. de Vos-Houben

L. Timmermans

Gertjan J.M. den Hartog

Aalt Bast

Geja J. Hageman

Oxid Med Cell Longev. 2013;2013:680414 


\begin{abstract}
Oxidative stress plays a major role in the pathophysiology of chronic inflammatory disease and it has also been linked to accelerated telomere shortening. Telomeres are specialized structures at the ends of linear chromosomes that protect these ends from degradation and fusion. Telomeres shorten with each cell division eventually leading to cellular senescence. Research has shown that poly(ADPribose)-polymerase-1 (PARP-1) and subtelomeric methylation play a role in telomere stability. We hypothesized that PARP-1 plays a role in accelerated aging in chronic inflammatory diseases due to its role as co-activator of NF-kb and AP-1. Therefore we evaluated the effect of chronic PARP-1 inhibition (by fisetin and minocycline) in human fibroblasts (HF) cultured under normal conditions and under conditions of chronic oxidative stress, induced by tert-butyl hydroperoxide ( $t$-BHP). Results showed that PARP-1 inhibition under normal culturing conditions accelerated the rate of telomere shortening. However, under conditions of chronic oxidative stress, PARP-1 inhibition did not show accelerated telomere shortening. We also observed a strong correlation between telomere length and subtelomeric methylation status of HF cells. We conclude that chronic PARP-1 inhibition appears to be beneficial in conditions of chronic oxidative stress, but may be detrimental under relatively normal conditions.
\end{abstract}




\section{Introduction}

Chronic inflammatory diseases afflict millions of people across the world leading to a substantial social and economic burden. From diabetes alone, 366 million people worldwide were suffering in 2011 (1). It is estimated that by the year 2030 this number will be almost doubled due to the rapid increase in the incidence of the disease caused by population growth, aging, urbanization and increasing prevalence of obesity and physical inactivity (2). Chronic inflammatory conditions in diabetes may lead to many serious complications, e.g. retinal damage, renal failure and cardiovascular diseases. Chronic inflammation and chronic oxidative stress, which occur in many chronic diseases, can contribute to the progress of these diseases by accelerating the rate of biological aging (3).

Accelerated biological aging has been associated with telomere shortening (4). Telomeres are nucleoprotein structures at the end of chromosomes consisting of stretches of a repetitive DNA sequence, TTAGGG in humans. They prevent chromosomal ends from being recognized as double strand breaks and protect them from end-to-end fusions and degradation. In somatic human cells, telomeres shorten with every round of replication (i.e. end replication problem) and cells are triggered into replicative senescence once telomeres shorten to a critical length (3; $5 ; 6)$. However, the end replication problem is not the only factor that contributes to the loss of telomeric DNA. Oxidative stress also appears to play a role in telomere shortening because of the high presence of GGG repeats, which are more readily oxidized compared to a lone guanine in the DNA $(7 ; 8)$. Recently, it has been shown that telomeric regions are favoured targets of a persistent DNA damage response induced by genotoxic and oxidative stress, both in vitro and in vivo (9). Oxidative stress induces single-strand breaks both directly and indirectly. These are less efficiently repaired in telomeric DNA as compared to genomic DNA and as a result increase the rate of telomere shortening due to incomplete replication (10).

Since oxidative stress plays a major role in chronic inflammatory diseases, telomere attrition may be involved in the pathophysiology of these diseases. Several studies have linked telomere shortening to various chronic metabolic and inflammatory diseases such as atherosclerosis, diabetes type 2, inflammatory bowel disease and chronic obstructive pulmonary disease, conditions that are all characterized by the presence of systemic oxidative stress (11-18). However, the exact underlying mechanisms of telomere shortening under conditions of chronic oxidative stress still have to be elucidated. 
Recent evidence indicates that epigenetic regulation may be important in telomere stability. Telomeres lack CpG dinucleotides which are susceptible to methylation, but the immediately adjacent subtelomeric regions have a high density of CpG sequences (19). In cells deficient of DNA methyltransferases (DNMTs) an induction of telomere elongation was observed which was associated with subtelomeric DNA hypomethylation (20). Also other studies have found a link between epigenetic status of subtelomeres and telomere length (21), which suggests a role for subtelomeric DNA methylation in telomere stability.

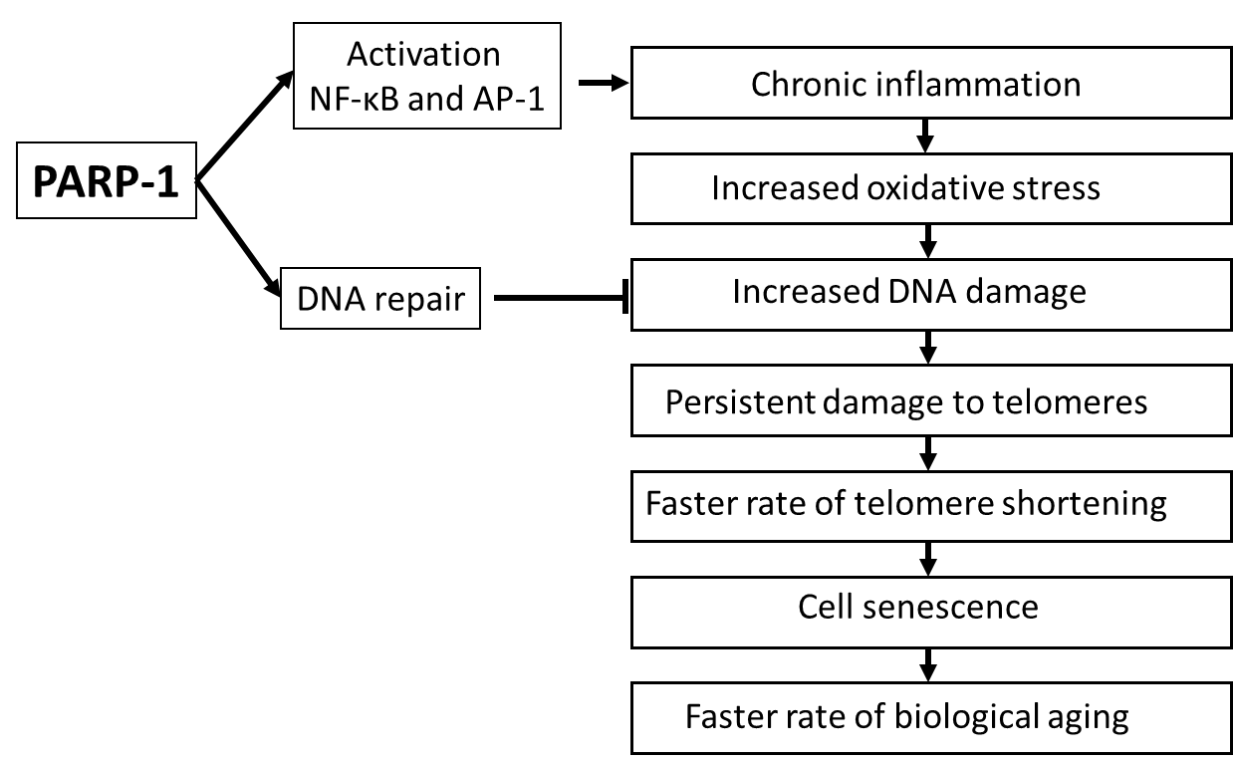

Figure 1: PARP-1 can influence telomere length regulation in two different ways. First, it can enhance DNA repair and protect the telomeres and contribute to a decrease in the rate of telomere shortening. Second, it can enhance the inflammatory response by activating NF-KB or AP-1, which will lead to more oxidative DNA damage which in turn could accelerate telomere shortening.

The activity of the nuclear enzyme Poly(ADP-ribose) polymerase-1 (PARP-1) has also been reported to play a role in this process of telomere stability. It has been shown that PARP-1 associates with telomere repeat binding factor 2 (TRF2), a telomere-specific DNA binding protein that protects chromosome ends by promoting the formation of the 'capped' state (22). Furthermore, PARP-1 has been implicated in the regulation of multiple physiological cellular functions like DNA repair, gene transcription, cell cycle progression, cell death, chromatin function and genomic stability $(23 ; 24)$. PARP-1 may influence telomere stability under conditions of chronic oxidative stress in two different ways (figure 1). First, through 
its function in repair of oxidative stress induced DNA damage. It can enhance repair, protect the telomeres and contribute to a decrease in the rate of telomere shortening. On the other hand, PARP-1 is also a co-activator of the stress-response related transcription factors Nuclear Factor-Kappa B (NF-KB) and Activator Protein1 (AP-1) and as a co-activator it can mediate the inflammatory response $(25 ; 26)$. In this role it may have a negative effect on telomere shortening, since inflammation will lead to more oxidative stress and oxidative DNA damage which could accelerate telomere shortening. Therefore, it is hypothesized that PARP-1 activity will contribute to accelerated telomere shortening and accelerated aging in chronic inflammatory diseases, through its function as a co-activator of inflammatory responses. The aim of this study was to investigate the effect of chronic PARP-1 inhibition on telomere stability under normal culturing conditions and under conditions of chronic oxidative stress in an in vitro model using human fibroblasts (HF). Additionally, the effect of prolonged culturing of HF cells under these conditions on subtelomeric methylation status was studied.

\section{Material and methods}

\section{Chemicals}

Minimum Essential Medium (MEM), Hank's Buffered Salt Solution (HBSS), fetal bovine serum (FCS), trypsin, essential amino acids, non-essential amino acids, vitamins, penicillin/streptomycin were all obtained from Invitrogen (Breda, The Netherlands). Bovine Serum Albumin (BSA), Minocycline, 4',6-diamidino-2phenylindole (DAPI), tert-butyl hydroperoxide ( $t$-BHP) and dimethyl sulfoxide (DMSO) were purchased from Sigma-Aldrich (Zwijndrecht, The Netherlands). The cell supernatant containing mouse monoclonal $10 \mathrm{H}$ anti-PAR polymer antibody was produced by Prof. W. Buurman (Maastricht University, Maastricht, The Netherlands). FITC-conjugated goat anti-mouse immunoglobin and fluorescent mounting medium were obtained from DAKO (Glostrup, Denmark). Hydrogen peroxide $\left(\mathrm{H}_{2} \mathrm{O}_{2}\right)$ was purchased from Merck (Darmstadt, Germany). Fisetin was obtained from Fit Ingredients (Haibach, Germany). Primary human fibroblast cells (normal non-fetal skin tissue) were acquired from Coriell (Coriell Institute for Medical Research, Camden, USA). Hela cell lines were kindly provided by Prof. Alexander Bürkle (University of Konstanz, Germany).

\section{Cell culture}

$\mathrm{HF}$ cells were cultured in minimum essential medium (MEM) + glutamax supplemented with $20 \%$ non-heat inactivated FCS, $1 \%$ penicillin/streptomycin, $0.5 \%$ non-essential amino acids, $0.5 \%$ essential amino acids and $0.03 \%$ vitamins. Cells were maintained at $37{ }^{\circ} \mathrm{C}$ in a $5 \% \mathrm{CO}_{2}$ atmosphere. All cells were passaged at 
approximately $80 \%$ confluency. To induce oxidative stress, parallel cultures were grown with or without exposure to $t$-BHP. To determine the concentration to be used, a concentration series was made from $5 \mathrm{nM}$ to $100 \mathrm{nM} t$-BHP. Cell viability was tested by the trypan blue exclusion test. Cells were viable at concentrations $<10 \mathrm{nM}$. At $5 \mathrm{nM}$ a viability of $>80 \%$ was found and we used this concentration for our experiments. Additionally, in a separate experiment the effect of PARP-1 inhibition was investigated by supplementation of fisetin $(10 \mathrm{mM}$ dissolved in DMSO, further diluted in culture medium to final concentration of $1 \mu \mathrm{M}$ ) or minocyline (10 $\mathrm{mM}$ dissolved in DMSO, further diluted in culture medium to final concentration of $100 \mathrm{nM}$ ) to the medium of HF cells in the presence or absence of $t$-BHP. All compounds were added to the culture medium every 2-3 days during passaging or medium renewal. The passage at which the experiment was started is called PO.

\section{Immunohistochemical staining of PAR-polymers}

To verify the PARP-1 inhibiting effects of the selected PARP-inhibitors, HF cells were seeded at a density of $15 \times 10^{4}$ cells per well in a six well plate. The next day, cells were treated with $300 \mu \mathrm{M} \mathrm{H} \mathrm{O}_{2}$ to induce PARP-1 overactivation and PAR-polymer formation. Treatment was done for 10 minutes in the presence or absence of fisetin $(1 \mu \mathrm{M})$ or minocycline $(100 \mathrm{nM})$, which were added 30 minutes before the $\mathrm{H}_{2} \mathrm{O}_{2}$ treatment. After incubation, the cells were trypsinized, washed with PBS and fixed in methanol. Fixed cells were put on microscope slides, washed with $0.1 \%$ BSA in PBS and incubated with $100 \mu \mathrm{l}$ mouse monoclonal $10 \mathrm{H}$ anti-PAR polymer antibody for one hour at room temperature. After washing with $0.1 \%$ BSA in PBS, cells were incubated with $100 \mu$ polyclonal goat anti-mouse immunoglobin/FITC for one hour at room temperature. Next, cells were washed again with $0.1 \%$ BSA in PBS and incubated for 10 minutes with $100 \mu$ DAPI solution. Subsequently, cells were mounted with fluorescent mounting medium and evaluated using a fluorescence microscope with Lucia GF 4.80 software. At least 100 cells per slide were studied for the presence of PAR polymers in the nucleus.

\section{DNA isolation}

DNA was extracted using the QIAamp DNA Mini Kit (Qiagen, Venlo, The Netherlands) according to the manufacturer's protocol and quantified using a nanodrop (Isogen Life Science, Belgium).

\section{Telomere length measurement}

Telomere length was determined by quantitative PCR as previously described (11; 27). Two master mixes were prepared, one with telomere primers and one with 
Human $\beta$ globin (HBG) primers (1x IQ SYBRgreen supermix from Biorad). Sequences and concentrations of the primers are shown in table 1. Sample DNA was pipetted in a 96-well plate at a final concentration of $10 \mathrm{ng} / \mu \mathrm{l} .20 \mu \mathrm{l}$ of the mastermix was added and the plate was shortly centrifuged. Each sample was run in triplicate. For the standard curve a reference DNA sample was diluted serially to produce three concentrations of $1.25,5$ and $10 \mathrm{ng} / \mu \mathrm{l}$. In every run, negative controls (MQ + mastermix) and reference samples were included. The references were derived from two different Hela cell lines, one with relatively short telomeres (Hela S3: 5.5 $\mathrm{kb}$ ) and one with long telomeres (Hela 229: 14-15 kb). By adding reference DNA of controls to each qPCR, a standard curve could be created and the absolute telomere length of the samples could be calculated as kilo-base pairs (kbp). Hela cell lines were kindly provided by Prof. Alexander Bürkle, University of Konstanz, Germany. The PCR was performed using a BioRad MyiQ iCycler Single Color RT-PCR detection system using iQTM SYBR ${ }^{\circledR}$ Green Supermix, containing iTaq Polymerase, dNTPs, SYBRGreen I and buffers (BioRad, CA, USA).

Table 1: Primer sequences and concentrations for telomere length PCR

\begin{tabular}{lll}
\hline Primer & Sequence (5' to 3') & $\begin{array}{l}\text { Concentration } \\
\text { (nM) }\end{array}$ \\
\hline Telomere 1 & CGGTTTGTTTGGGTTTGGGTTTGGGTTTGGGTTTGGGTT & 100 \\
Telomere 2 & GGCTTGCCTTACCCTTACCCTTACCCTTACCCTTACCCT & 900 \\
HBG Forward & GCTTCTGACACAACTGTGTTCACTAGC & 300 \\
HBG Reverse & CACCAACTTCATCCACGTTCACC & 700 \\
\hline
\end{tabular}

\section{Telomerase activity}

Telomerase activity was evaluated by Telomeric Repeat Amplification Protocol (TRAP) assay using the TeloTAGGG Telomerase PCR ELISAPLUS (Roche Diagnostics, Milan, Italy) which is an extension of the original method described by Kim et al. (28). Cell extracts (1-3 $\times 10^{5}$ cell equivalents) were employed in the first step, in which telomerase adds telomeric repeats (TTAGGG) to the $3^{\prime}$-end of the biotinlabeled synthetic P1-TS primer. These elongation products, as well as the internal standard (IS), were amplified by PCR. In the second step the PCR products were split into two aliquots, denatured and hybridized separately to digoxigenin-(DIG)labeled detection probes, specific for the telomeric repeats and for the IS, respectively. Results obtained by densitometric analysis were normalized upon the data of IS and expressed as relative telomerase activities (RTA). 


\section{Subtelomere methylation}

Bisulfite treatment of genomic DNA was performed with an EZ DNA methylation kit (Zymo Research, CA, USA). The bisulfite-treated DNA was subjected to a polymerase chain reaction ( $P C R$ ) to amplify the subtelomere region with the primers specific for chromosome arm $2 \mathrm{p}$. Primer sequences were obtained from Lee et al (29). Methylation specific primers were: forward: ATGATTAGCGAGTTCGGTTTTAAC and reverse: GAATCGCGCCAAATATATACG and primers specific for unmethylated DNA were: forward: GATGATTAGTGAGTTTGGTTTTAATG and reverse: ACAAATCACACCAAATATATACAAA. PCR reactions were performed in a total volume of $25 \mu l$ containing $1 x$ Taq polymerase buffer, $2 \mathrm{mM} \mathrm{MgCl} 2,0.2 \mathrm{mM}$ dNTPs, $0.6 \mu \mathrm{M}$ of each primer, $1 \mathrm{U}$ Taq polymerase and $500 \mathrm{ng}$ bisulfite-treated DNA. PCR amplification was conducted as follows: Initial denaturation at $95^{\circ} \mathrm{C}$ for 10 minutes, followed by 40 cycles of $94^{\circ} \mathrm{C}$ for 30 seconds, $58^{\circ} \mathrm{C}$ for 30 seconds and $72^{\circ} \mathrm{C}$ for 30 seconds and ending with an extension at $72^{\circ} \mathrm{C}$ for 10 minutes. Amplified products were run on an ethidium bromide stained $2 \%$ agarose gel. Quantification was done by measuring grey values with the program ImageJ (http://rsbweb.nih.gov/ij/).

\section{Statistical analysis}

Differences between groups for telomere length and PAR polymer staining were tested using the Mann-Whitney $U$ test. Effects of PARP-1 inhibition were tested using a Wilcoxon signed-rank test. The association between telomere length and subtelomeric methylation status was evaluated using the non-parametric Spearman's rank correlation coefficient. P-values $<0.05$ were considered statistically significant and $\mathrm{p}$-values $<0.1$ were considered statistical trends. Statistical analyses were analyzed with SPSS for Windows (version 20.0; SPSS Inc., Chicago, IL, USA).

\section{Results}

To determine whether chronic exposure of HF cells to oxidative stress induces a faster rate of telomere shortening we determined telomere length of HF cells exposed to $5 \mathrm{nM} t$-BHP. HF cells exposed to $t$-BHP showed significantly shorter telomeres than non-exposed cells of the same passage number $(p<0.01)$ (figure $2 \mathrm{~A})$. It was also observed that the telomere length significantly decreased over time in non-exposed cells as well as in exposed cells ( $p<0.001)$ (Figure 2A). In addition, the population doubling time was increased in the exposed cells compared to nonexposed cells. Telomere length decreased with approximately $1490 \mathrm{bp}$ after 45 population doublings in the non-exposed cells and with 1938 bp after 45 population doublings in the exposed cells. In the non-exposed cells, at several time- 
points the telomere length appeared to increase instead of decrease. To be able to explain this phenomenon we measured the telomerase activity in the cells. As expected (as we used a primary cell line), no detectable telomerase activity was measured (figure 2B).
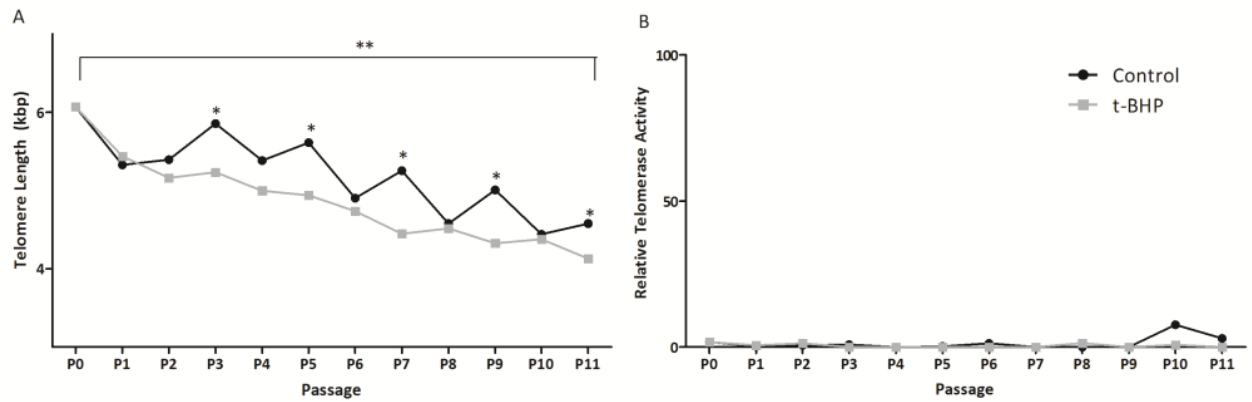

Figure 2: Telomere length (A) and telomerase activity (B) in human fibroblasts during culturing in absence (black line) or presence (grey line) of $5 \mathrm{nM}$ tert-butyl hydroperoxide ( $t$ BHP). HF cells exposed to $t$-BHP showed significantly shorter telomeres than non-exposed cells of the same passage number. Telomere length significantly decreased over time in nonexposed cells as well as in exposed cells. ${ }^{* *}=p<0.001$ compared to p0 (start of the experiment); ${ }^{*}=p<0.01$ compared to non-exposed cells of the same passage number. Mean \pm SD of telomere length is shown. If telomerase activity was present, the relative telomerase activity value would be higher than 100 . The values are lower than 10 , which indicates that there is no telomerase activity in these cells.

To confirm the PARP-1 inhibiting effect of fisetin and minocycline, HF cells were treated with $\mathrm{H}_{2} \mathrm{O}_{2}$ to induce PARP activity. The formation of PAR-polymers in these cells was evaluated using immunohistochemical staining. In non-treated cells, no PAR-polymer formation was observed. Treatment with $\mathrm{H}_{2} \mathrm{O}_{2}$ induced an increase in the number of PAR polymer positive cells $(p<0.01)$. Preincubation with fisetin decreased the number of PAR-polymer positive cells with $40 \%$ indicating that $1 \mu \mathrm{M}$ fisetin mildly inhibits PARP-1. Preincubation with $100 \mathrm{nM}$ minocycline resulted in a $90 \%$ reduction in the number of PAR-polymer positive cells $(p<0.001)$, indicating that minocycline is a strong inhibitor of PARP-1 (figure 3 ). 


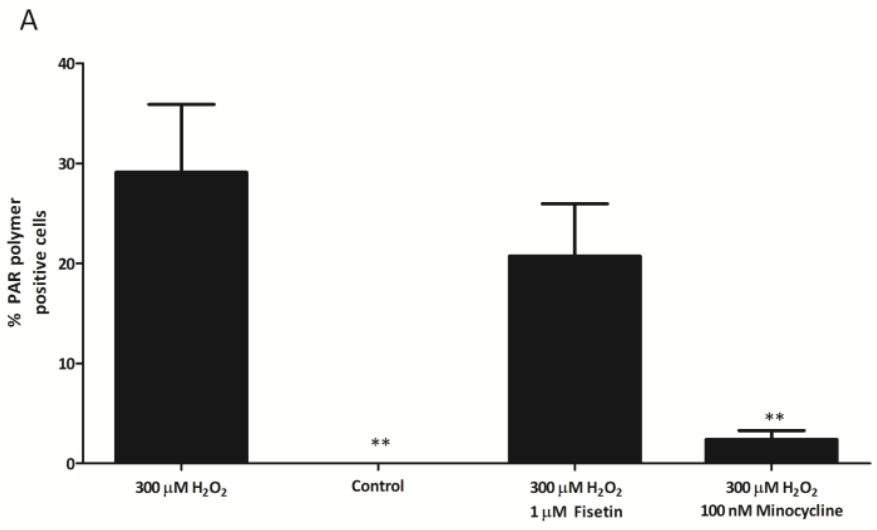

B

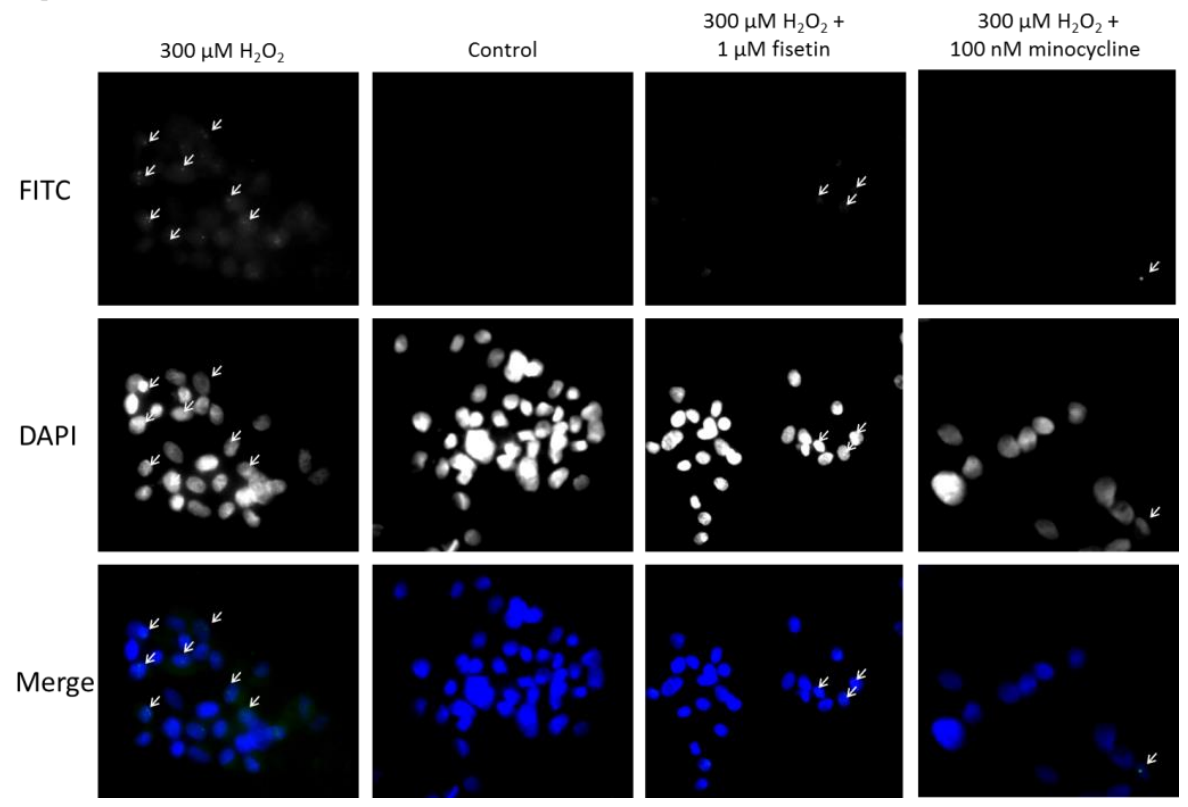

Figure 3: A) PAR polymer formation in human fibroblasts treated with $300 \mu \mathrm{M} \mathrm{H}_{2} \mathrm{O}_{2}$ for 10 minutes in the presence or absence of $1 \mu \mathrm{M}$ fisetin or $100 \mathrm{nM}$ minocycline which were added 30 minutes before the $\mathrm{H}_{2} \mathrm{O}_{2}$ treatment. ${ }^{* *}=\mathrm{p}<0.05$ compared to cells treated with $300 \mu \mathrm{M} \mathrm{H} \mathrm{H}_{2} \mathrm{O}_{2}$. B) Representative photographs of PAR polymer staining. Arrows indicate examples of PAR polymer positive cells. Magnification: 400x.

To investigate the effect of chronic PARP-1 inhibition on telomere length regulation under conditions of chronic oxidative stress, HF cells were cultured with $1 \mu \mathrm{M}$ fisetin or $100 \mathrm{nM}$ minocycline in the presence or absence of $t$-BHP. After 10 passages, telomeres in all culturing conditions were shorter compared to telomere length at the start of the experiment (figure 4). In addition, culturing the cells in 36 
presence of $t-\mathrm{BHP}$, fisetin and minocycline $(\mathrm{p}<0.1)$ resulted in shorter telomeres compared to untreated cells. However, culturing them in presence of minocycline or fisetin in combination with $t$-BHP did not result in accelerated telomere shortening when compared to untreated cells (figure 4).
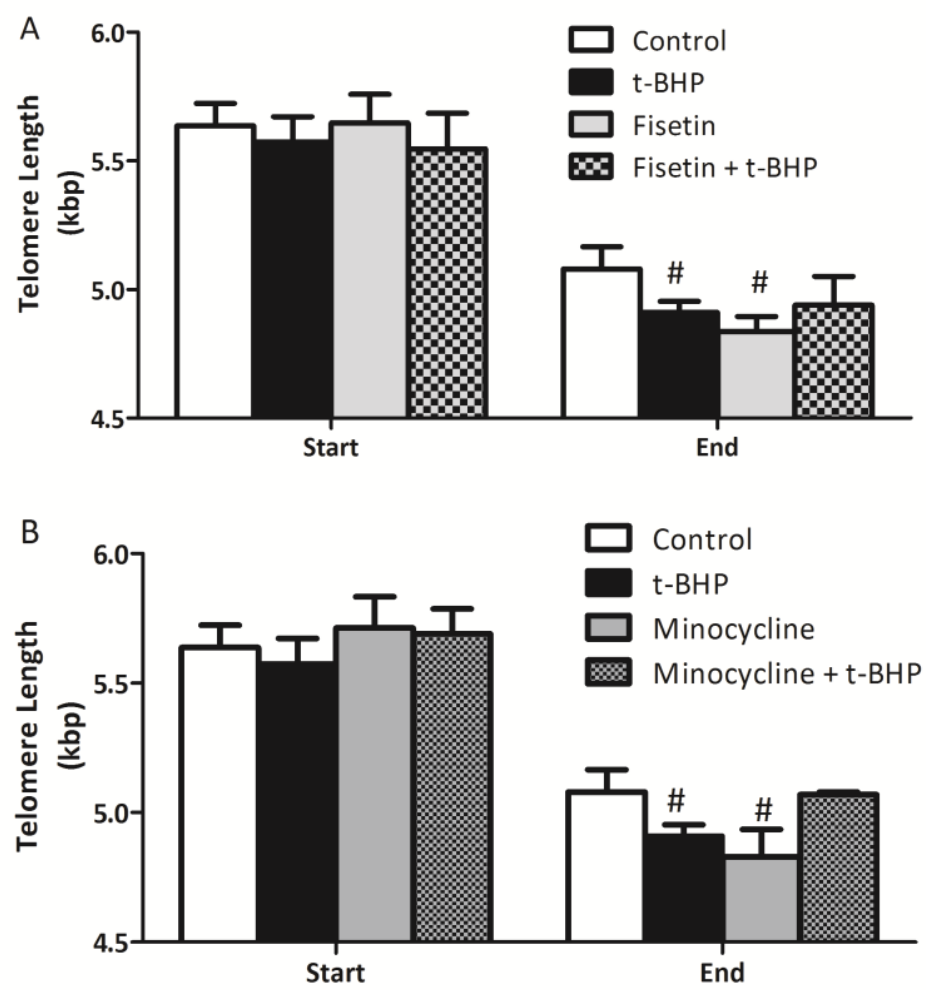

Figure 4: Effect of PARP inhibition by $1 \mu \mathrm{M}$ fisetin (A) and $100 \mathrm{nM}$ minocycline (B) on telomere length of human fibroblast cells at the start (p0-p2) and end ( $p 9-p 11)$ of the experiment cultured under normal conditions or under conditions of chronic oxidative stress induced by tert-butyl hydroperoxide ( $t$-BHP). $\#=p<0.1$ compared to control.

Additionally, at the end of the experiment cells treated with $t$-BHP, minocyline and $t$-BHP and fisetin showed a senescence-like phenotype (flattened, contracted and detached cells (30)). Cells cultured under the other conditions had a normal appearance. Also, cells cultured with $t$-BHP, $t$-BHP and fisetin and minocycline alone showed a decreased growth rate, resulting in a longer period before passaging (table 2). 


\section{Chapter 2}

Table 2: Average time span to reach $80 \%$ confluency in HF cultures (moment of passage). Mean \pm SD are shown.

\begin{tabular}{ll}
\hline Condition & Days between passage (average P0-P11) \\
\hline Control & $5.5 \pm 1.0$ \\
$t$-BHP & $6.1 \pm 1.2$ \\
Fisetin & $5.6 \pm 1.0$ \\
Fisetin $+t$-BHP & $6.7 \pm 2.4$ \\
Minocycline & $6.2 \pm 2.2$ \\
Minocycline $+t$-BHP & $6.1 \pm 1.0$ \\
\hline
\end{tabular}

To examine the effect of subtelomeric methylation on telomere stability, the methylation status of chromosome $2 p$ was evaluated at the start and end of the experiment (figure 5). At the start of the experiment HF cells showed an unmethylated pattern of the subtelomere region of chromosome $2 \mathrm{p}$. At the end of the experiment differences between the conditions were observed. Cells cultured under normal conditions showed a methylation pattern that was similar to the pattern at the start of the experiment, while cells treated with $t$-BHP or minocycline showed an increase in methylation of almost $30 \%$. For cells treated with fisetin this increase was only half ( $15 \%)$. A Spearman's correlation was run to determine the relationship between the level of methylation and telomere length, which revealed a statistically significant correlation $\left(r_{s}=0.668 ; p=0.018\right)$.

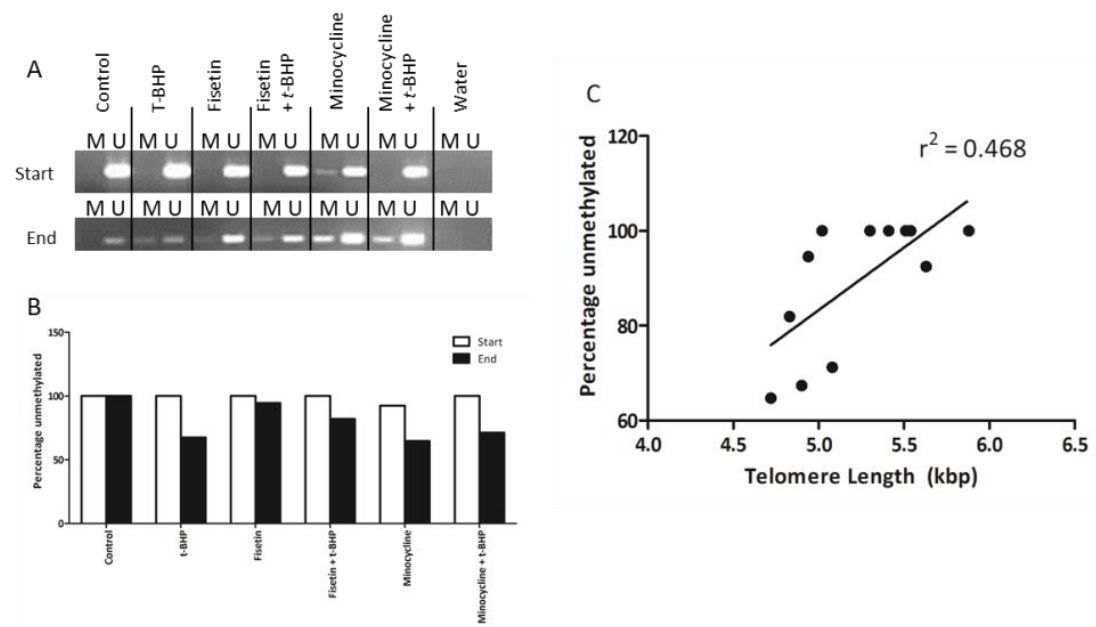

Figure 5: A: Methylation specific PCR (MSP) result for chromosome $2 p$ at passage 1 (start) and passage 10 (end). $M$ and $U$ indicate amplification from methylation and unmethylation sequence-specific primers. Water indicates MSP result with no template DNA (negative control). Densitometry of the photographs is shown in B. C: Spearman's correlation revealed a statistically significant correlation $\left(r_{s}=0.668 ; p=0.018\right)$ between telomere length and the level of methylation. 


\section{Discussion}

In this study we investigated the effect of chronic PARP-1 inhibition on telomere stability under conditions of chronic oxidative stress. We used prolonged culturing of $\mathrm{HF}$ as a model for development of cellular senescence. To induce oxidative stress, we cultured HF in presence of $t$-BHP, which is a short-chain organic hydroperoxide that produces free radicals after metabolic activation (31).

\section{Chronic oxidative stress induces telomere shortening}

Prolonged culturing of HF resulted in telomeres shortening, indicating biological aging of HF. In addition, exposure to chronic oxidative stress significantly increased the rate of telomere shortening. Because the observed telomere shortening might be caused by an increased rate of cell division, the population doubling times were calculated. We found that the population doubling time was increased in the cells exposed to $t$-BHP, which could be caused by an increased level of apoptosis, leading to a decreased cell proliferation capacity. Unexpectedly, at several time points in the non-exposed cells telomere length was increased. This appeared not to be caused by increased telomerase activity, since telomerase activity was absent or very low in this primary cell line. An alternative mechanism may be involved which can be adopted by yeast and human telomerase-deficient cell lines, the alternative lengthening of telomeres (ALT) for telomere maintenance. ALT appears to be mechanistically related to survival in cells and to involve a homologous recombination based mechanism in which one telomere can be extended using the telomere from a non-homologous chromosome arm or extrachromosomal telomeric DNA (32-34). This mechanism has been demonstrated to exist in HF (35; 36). Other processes may contribute to the observed increase in telomere length as well, such as survival and selection of cells with longer telomeres and with a better adaptation to the culturing conditions.

\section{Inhibition of PARP-1 by fisetin and minocycline}

Fisetin and minocycline were used to inhibit PARP-1. Fisetin is a flavonoid that is normally present in dietary sources like fruits and vegetables (37). Fisetin has been described to have many beneficial health effects, like memory-enhancement (38). It was found to possess anti-inflammatory effects via inhibition of the activation of NF-KB (39) and it has been shown previously that fisetin inhibited PARP-1 in pulmonary epithelial cells (40).

At a concentration of $1 \mu \mathrm{M}$ fisetin caused a mild inhibition of PARP-1 activity when cells were exposed to $\mathrm{H}_{2} \mathrm{O}_{2}$. Chronic treatment of $\mathrm{HF}$ cells with fisetin resulted in shorter telomeres compared to control cells. In cells cultured in the presence of 
both fisetin and $t$-BHP average telomere length was not significantly different compared to control cells. This finding appeared to support our hypothesis of the involvement of PARP-1 activity in telomere stability.

A recent study by Sengupta et al. showed fisetin to be a promising ligand for the formation of a four-stranded structure known as a G-quadruplex (41). Formation of quadruplexes has been shown to decrease the activity of telomerase, but it is also inhibits the ALT mechanism $(42 ; 43)$. Since this mechanism might play a role in our model, it is possible that quadruplex formation by fisetin under normal situations causes a faster rate of telomere shortening due to impairment of ALT. Gquadruplex formation is beneficial in anti-cancer therapy, as it impedes telomere elongation, a mechanism most tumor cells use for unlimited proliferation (44).

Minocycline, also known as minocycline hydrochloride, is a member of the broad spectrum tetracyclines antibiotics. It is primarily used to treat acne and other skin infections and exerts anti-inflammatory effects that are completely separate from its antimicrobial actions (45). We showed that nanomolar concentrations of minocycline significantly inhibited PARP-1 activity, as was previously reported by Alano et al. (46). Culturing of cells in the presence of $100 \mathrm{nM}$ minocycline resulted in shorter average telomere length as compared to control cells. On the other hand, when cells were cultured in the presence of minocycline in combination with $t$-BHP, average telomere length was not significantly decreased when compared to control. These findings, together with the findings of inhibition by fisetin, appeared to support our hypothesis that PARP-1 activity contributes to telomere stability and that inhibition of PARP-1 activity increases the rate of telomere shortening. However, under conditions of chronic oxidative stress inhibition of PARP-1 appeared to results in a decreased rate of telomere shortening. The antiinflammatory activity of fisetin and minocycline may also contribute to the stabilizing effect on telomere length under chronic oxidative stress conditions.

The effects of chronic minocycline treatment on mammalian cells are still largely unknown. Research mainly focused on examining the possible neuroprotective and anti-inflammatory effects of minocycline on progression of neurodegenerative disorders like multiple sclerosis (MS) and amyotrophic lateral sclerosis (ALS). It has been described that minocycline is effective in various experimental models of ALS, Parkinson and Huntington disease (47-51). In a study of patients with acute stroke it was found that treatment with minocycline significantly improved the outcome compared to patients treated with placebo (52). Since oxidative stress is known to play a role in neuronal cell death in these diseases (53), PARP-1 inhibition might be 
an underlying mechanism by which minocycline exerts these neuroprotective effects. However, minocycline has also been shown to be effective in other disease models. It was already found that minocycline may prevent blindness in a rat model of diabetic retinopathy (45). Several studies have suggested an important role of PARP activation in the pathogenesis of diabetic complications like nephropathy, neuropathy and retinopathy (54-56). Furthermore, minocycline has been shown to exert in vivo cardioprotective effects by suppressing oxidative stress and therefore preventing fetal cardiac myocyte death after prenatal cocaine exposure (57).

A selective PARP-1 inhibitor was not tested in our experiments. However, Beneke et al described an experiment in which they exposed cells to the well-known PARP1 inhibitor 3-aminobenzamide (3-AB) and measured telomere length (58). They found in two mammalian cell systems (hamster and human) that pharmacological inhibition of PARP1 led to a fast, dose-dependent decrease of telomere length. These results are comparable with the results we obtained in our experiment in which fisetin and minocycline were applied as PARP inhibitors.

The effects on telomere length were observed to be similar with both inhibitors. However, minocycline treated cells showed morphological changes at an earlier passage than untreated cells or cells treated with fisetin. This might be explained by the fact that minocycline is known to have strong PARP-1 inhibiting capacity only, whereas fisetin has been reported to exert other effects that may enhance cellular function (37). Fisetin is an activator of sirtuin 1 (SIRT1), a histone deacetylase (59). An increased activity of SIRT1 is associated with enhanced survival and longevity. Fisetin has already been shown to increase the lifespan of the yeast Saccharomyces cerevisiae (59). Additionally, fisetin is able to inhibit COX2 expression (60). It has been shown that selective COX2 inhibitors can modulate cellular senescence in human dermal fibroblasts (61). Activation of SIRT1 and/or inhibition of COX2 by fisetin could explain why cells treated with fisetin had a normal appearance and cells treated with minocycline, which is not known as a SIRT1 activator, were in a senescence state at passage 11, although they had similar telomere length.

\section{Subtelomeric methylation}

Mouse models and in vitro studies suggest a role for subtelomeric methylation in telomere length regulation $(20 ; 21)$. Normally, telomeres have a "closed" conformation which is established by epigenetic markers, including methylation of the subtelomeric region. When telomeres become shorter, the epigenetic markers decrease, which leads to a more "open" confirmation that allows a greater 


\section{Chapter 2}

accessibility for telomere-elongating activities (62). It has been shown that the subtelomeric region of Alzheimer patients with short telomeres was hypermethylated (63). In contrast, in patients with Parkinson's disease an increase in short telomeres with subtelomeric hypomethylation was found (64). PARP-1 is also known to be able to influence DNA methylation by regulation the expression and activity of DNMT1 or by direct interaction with DNMT1 (65-67). We observed a correlation between methylation status and telomere length. We found a change from unmethylated status at the beginning of the experiment to $50 \%$ methylated in conditions with the shortest telomeres at the end of the experiment of the subtelomeric region of chromosome $2 \mathrm{p}$. Cells that were chronically treated with fisetin showed less increase in methylation, which could be caused by the ability of fisetin to inhibit SssI DNMT- and DNMT1-mediated DNA methylation (68).

\section{Conclusion}

Chronic fisetin treatment of $\mathrm{HF}$ at physiological concentrations resulted in shorter telomeres compared to control cells, indicating reduced telomere stability and enhanced biological aging of these cells. Under the assumption that it is healthy, fisetin is often added to nutritional supplements at relatively high concentrations. Since the biological effects of regular consumption of high doses fisetin (and also flavonoids in general) are not known, thorough safety evaluation is warranted with respect to these nutritional supplements. Chronic minocycline treatment also enhanced telomere shortening. This implies that precaution should be taken when minocycline is subscribed as a chronic treatment.

However, under conditions of chronic oxidative stress, both fisetin and minocycline appeared to reduce the rate of telomere shortening. Since our study was limited to testing the effects of fisetin and minocycline in an in vitro model with HF cells that were chronically exposed to oxidative stress, more research is needed to evaluate possible positive effects of fisetin and minocycline in chronic inflammatory diseases. It can be concluded that chronic administration of pharmaceuticals or nutraceuticals with PARP inhibiting activity appears to be beneficial in conditions of chronic oxidative stress, but may be detrimental under relatively normal conditions. 


\section{References}

1. Whiting DR, Guariguata L, Weil C, Shaw J: IDF Diabetes Atlas: Global estimates of the prevalence of diabetes for 2011 and 2030. Diabetes Research and Clinical Practice 2011;94:311-321

2. Shaw JE, Sicree RA, Zimmet PZ: Global estimates of the prevalence of diabetes for 2010 and 2030. Diabetes Research and Clinical Practice 2010;87:4-14

3. Houben JM, Moonen HJ, van Schooten FJ, Hageman GJ: Telomere length assessment: biomarker of chronic oxidative stress? Free Radic Biol Med 2008;44:235-246

4. Veryan C, Christopher PN, Eva A, Massimo M, Joris D, Jessica LB, Jouke Jan H, Krista F, Tõnu $E$, Ida $S$, Linda $B$, Dale RN, Irene Mateo L, Perttu S, Sara H, Mary KM, Jutta $P$, Giuseppe DN, Paul FOR, Danish S, Najaf A, Anthony JB, Marian B, Rudolf AdB, Stefan B, Peter SB, Paul RB, Anton JMC, Matthew D, Yanbin D, Konstantinos D, Elena D, Johan GE, Katia G, Dehuang G, Anna-Liisa H, Anjali KH, Jeanine JH-D, Laura K, Lennart CK, Johannes K, Norman K, Vasiliki L, Elisabeth MvL, Pamela AM, Reedik M, Patrik KEM, Satu M, Mark IM, Sarah EM, Evelin M, Grant WM, Ben AO, Aarno $P$, Annette $P$, Helen $P$, Anneli $P$, Inga $P$, Samuli $R$, Veikko $S$, Suchiman HED, Ana MV, Niek V, Ana V, Xiaoling W, Wichmann HE, Elisabeth W, Gonneke W, Margaret JW, Kai X, Xiangjun X, Dirk JvV, Alberico LC, Martin DT, Alistair SH, Alexandra IFB, Wiek HvG, Haidong Z, consortium CA, Jeanette E, Muredach PR, Sekar K, Heribert S, Philippa JT, Nancy LP, Markus P, Willem O, Jaakko K, Nicholas GM, Cornelia MvD, liris H, Christian G, Andres M, Dorret IB, Marjo-Riitta J, Slagboom PE, John RT, Tim DS, Pim van der H, Nilesh JS: Identification of seven loci affecting mean telomere length and their association with disease. Nature Genetics 2013;45:422-427

5. Harley $C B$, Futcher $A B$, Greider $C W$ : Telomeres shorten during ageing of human fibroblasts. Nature 1990;345:458-460

6. Blackburn EH: Structure and function of telomeres. Nature 1991;350:569-573

7. Rhee DB, Ghosh A, Lu J, Bohr VA, Liu Y: Factors that influence telomeric oxidative base damage and repair by DNA glycosylase OGG1. DNA Repair (Amst) 2011;10:34-44

8. von Zglinicki T: Oxidative stress shortens telomeres. Trends Biochem Sci 2002;27:339-344

9. Hewitt G, Jurk D, Marques FD, Correia-Melo C, Hardy T, Gackowska A, Anderson R, Taschuk M, Mann J, Passos JF: Telomeres are favoured targets of a persistent DNA damage response in ageing and stress-induced senescence. Nat Commun 2012;3:708

10. Petersen S, Saretzki G, von Zglinicki T: Preferential accumulation of single-stranded regions in telomeres of human fibroblasts. Exp Cell Res 1998;239:152-160

11. Houben JM, Mercken EM, Ketelslegers HB, Bast A, Wouters EF, Hageman GJ, Schols AM: Telomere shortening in chronic obstructive pulmonary disease. Respir Med 2009;103:230236

12. Savale L, Chaouat A, Bastuji-Garin S, Marcos E, Boyer L, Maitre B, Sarni M, Housset B, Weitzenblum E, Matrat M, Le Corvoisier P, Rideau D, Boczkowski J, Dubois-Rande JL, Chouaid C, Adnot S: Shortened Telomeres in Circulating Leukocytes of Patients with Chronic Obstructive Pulmonary Disease. Am J Respir Crit Care Med 2009;

13. Adaikalakoteswari A, Balasubramanyam M, Mohan V: Telomere shortening occurs in Asian Indian Type 2 diabetic patients. Diabet Med 2005;22:1151-1156

14. Aviv A: Chronology versus biology: telomeres, essential hypertension, and vascular aging. Hypertension 2002;40:229-232

15. Benetos A, Gardner JP, Zureik M, Labat C, Xiaobin L, Adamopoulos C, Temmar M, Bean $\mathrm{KE}$, Thomas F, Aviv A: Short telomeres are associated with increased carotid atherosclerosis in hypertensive subjects. Hypertension 2004;43:182-185

16. Kinouchi $Y$, Hiwatashi N, Chida M, Nagashima F, Takagi S, Maekawa H, Toyota T: Telomere shortening in the colonic mucosa of patients with ulcerative colitis. J Gastroenterol 1998;33:343-348 
17. Rode L, Bojesen SE, Weischer M, Vestbo J, Nordestgaard BG: Short telomere length, lung function and chronic obstructive pulmonary disease in 46396 individuals. Thorax 2013;68:429-435

18. Salpea KD, Talmud PJ, Cooper JA, Maubaret CG, Stephens JW, Abelak K, Humphries SE: Association of telomere length with type 2 diabetes, oxidative stress and UCP2 gene variation. Atherosclerosis 2010;209:42-50

19. Steinert S, Shay JW, Wright WE: Modification of subtelomeric DNA. Mol Cell Biol 2004;24:4571-4580

20. Gonzalo S, Jaco I, Fraga MF, Chen T, Li E, Esteller M, Blasco MA: DNA methyltransferases control telomere length and telomere recombination in mammalian cells. Nature cell biology 2006;8:416-424

21. Benetti R, Garcia-Cao M, Blasco MA: Telomere length regulates the epigenetic status of mammalian telomeres and subtelomeres. Nat Genet 2007;39:243-250

22. Ohki R, Ishikawa F: Telomere-bound TRF1 and TRF2 stall the replication fork at telomeric repeats. Nucleic Acids Res 2004;32:1627-1637

23. Pacher P, Szabo C: Role of the peroxynitrite-poly(ADP-ribose) polymerase pathway in human disease. Am J Pathol 2008;173:2-13

24. Kraus WL, Hottiger MO: PARP-1 and gene regulation: Progress and puzzles. Mol Aspects Med 2013;

25. Hassa PO, Hottiger MO: A role of poly (ADP-ribose) polymerase in NF-kappaB transcriptional activation. Biol Chem 1999;380:953-959

26. Andreone TL, O'Connor M, Denenberg A, Hake PW, Zingarelli B: Poly(ADP-ribose) polymerase-1 regulates activation of activator protein-1 in murine fibroblasts. J Immunol 2003;170:2113-2120

27. Cawthon RM: Telomere measurement by quantitative PCR. Nucleic Acids Res 2002;30:e47

28. Kim NW, Piatyszek MA, Prowse KR, Harley CB, West MD, Ho PL, Coviello GM, Wright WE, Weinrich SL, Shay JW: Specific association of human telomerase activity with immortal cells and cancer. Science 1994;266:2011-2015

29. Lee ME, Rha SY, Jeung H-C, Chung HC, Oh B-K: Subtelomeric DNA methylation and telomere length in human cancer cells. Cancer Letters 2009;281:82-91

30. Bladier C, Wolvetang EJ, Hutchinson P, de Haan JB, Kola I: Response of a primary human fibroblast cell line to H2O2: senescence-like growth arrest or apoptosis? Cell Growth Differ 1997;8:589-598

31. Hix S, Kadiiska MB, Mason RP, Augusto O: In Vivo Metabolism of tert-Butyl Hydroperoxide to Methyl Radicals. EPR Spin-Trapping and DNA Methylation Studies. Chemical Research in Toxicology 2000;13:1056-1064

32. Yang Q: Cellular senescence, telomere recombination and maintenance. Cytogenet Genome Res 2008;122:211-218

33. Akimcheva S, Zellinger B, Riha K: Genome stability in Arabidopsis cells exhibiting alternative lengthening of telomeres. Cytogenet Genome Res 2008;122:388-395

34. Dunham MA, Neumann AA, Fasching CL, Reddel RR: Telomere maintenance by recombination in human cells. Nat Genet 2000;26:447-450

35. Hande MP, Balajee AS, Tchirkov A, Wynshaw-Boris A, Lansdorp PM: Extra-chromosomal telomeric DNA in cells from Atm(-/-) mice and patients with ataxia-telangiectasia. Hum Mol Genet 2001;10:519-528

36. Vidacek NS, Cukusic A, Ivankovic M, Fulgosi $H$, Huzak M, Smith JR, Rubelj I: Abrupt telomere shortening in normal human fibroblasts. Exp Gerontol 2010;45:235-242

37. Khan N, Syed DN, Ahmad N, Mukhtar H: Fisetin: a dietary antioxidant for health promotion. Antioxidants \& redox signaling 2013;19:151-162 
38. Maher P, Akaishi T, Abe K: Flavonoid fisetin promotes ERK-dependent long-term potentiation and enhances memory. Proceedings of the National Academy of Sciences 2006;103:16568-16573

39. de Sousa RR, Queiroz KC, Souza AC, Gurgueira SA, Augusto AC, Miranda MA, Peppelenbosch MP, Ferreira CV, Aoyama H: Phosphoprotein levels, MAPK activities and NFkappaB expression are affected by fisetin. J Enzyme Inhib Med Chem 2007;22:439-444

40. Geraets L, Moonen HJ, Brauers K, Wouters EF, Bast A, Hageman GJ: Dietary flavones and flavonoles are inhibitors of poly(ADP-ribose)polymerase-1 in pulmonary epithelial cells. J Nutr 2007;137:2190-2195

41. Sengupta B, Pahari B, Blackmon L, Sengupta PK: Prospect of Bioflavonoid Fisetin as a Quadruplex DNA Ligand: A Biophysical Approach. PLoS One 2013;8:e65383

42. Wang Q, Liu J-q, Chen Z, Zheng K-w, Chen C-y, Hao Y-h, Tan Z: G-quadruplex formation at the $3^{\prime}$ end of telomere DNA inhibits its extension by telomerase, polymerase and unwinding by helicase. Nucleic Acids Research 2011;

43. Gomez D, Mergny JL, Riou JF: Detection of telomerase inhibitors based on g-quadruplex ligands by a modified telomeric repeat amplification protocol assay. Cancer Res 2002;62:3365-3368

44. Oganesian L, Bryan TM: Physiological relevance of telomeric G-quadruplex formation: a potential drug target. Bioessays 2007;29:155-165

45. Krady JK, Basu A, Allen CM, Xu Y, LaNoue KF, Gardner TW, Levison SW: Minocycline reduces proinflammatory cytokine expression, microglial activation, and caspase-3 activation in a rodent model of diabetic retinopathy. Diabetes 2005;54:1559-1565

46. Alano CC, Kauppinen TM, Valls AV, Swanson RA: Minocycline inhibits poly(ADP-ribose) polymerase-1 at nanomolar concentrations. Proceedings of the National Academy of Sciences 2006;103:9685-9690

47. Du Y, Ma Z, Lin S, Dodel RC, Gao F, Bales KR, Triarhou LC, Chernet E, Perry KW, Nelson DL, Luecke S, Phebus LA, Bymaster FP, Paul SM: Minocycline prevents nigrostriatal dopaminergic neurodegeneration in the MPTP model of Parkinson's disease. Proc Natl Acad Sci U S A 2001;98:14669-14674

48. Wu DC, Jackson-Lewis V, Vila M, Tieu K, Teismann P, Vadseth C, Choi D-K, Ischiropoulos $\mathrm{H}$, Przedborski S: Blockade of Microglial Activation Is Neuroprotective in the 1-Methyl-4Phenyl-1,2,3,6-Tetrahydropyridine Mouse Model of Parkinson Disease. The Journal of Neuroscience 2002;22:1763-1771

49. Zhu S, Stavrovskaya IG, Drozda M, Kim BY, Ona V, Li M, Sarang S, Liu AS, Hartley DM, Wu DC, Gullans S, Ferrante RJ, Przedborski S, Kristal BS, Friedlander RM: Minocycline inhibits cytochrome $\mathrm{c}$ release and delays progression of amyotrophic lateral sclerosis in mice. Nature 2002;417:74-78

50. Van Den Bosch L, Tilkin P, Lemmens G, Robberecht W: Minocycline delays disease onset and mortality in a transgenic model of ALS. Neuroreport 2002;13:1067-1070

51. Chen M, Ona VO, Li M, Ferrante RJ, Fink KB, Zhu S, Bian J, Guo L, Farrell LA, Hersch SM, Hobbs W, Vonsattel JP, Cha JH, Friedlander RM: Minocycline inhibits caspase-1 and caspase3 expression and delays mortality in a transgenic mouse model of Huntington disease. Nat Med 2000;6:797-801

52. Lampl Y, Boaz M, Gilad R, Lorberboym M, Dabby R, Rapoport A, Anca-Hershkowitz M, Sadeh M: Minocycline treatment in acute stroke: an open-label, evaluator-blinded study. Neurology 2007;69:1404-1410

53. Emerit J, Edeas M, Bricaire F: Neurodegenerative diseases and oxidative stress. Biomed Pharmacother 2004;58:39-46 
54. Li F, Szabo C, Pacher P, Southan GJ, Abatan OI, Charniauskaya T, Stevens MJ, Obrosova IG: Evaluation of orally active poly(ADP-ribose) polymerase inhibitor in streptozotocindiabetic rat model of early peripheral neuropathy. Diabetologia 2004;47:710-717

55. Szabo C, Biser A, Benko R, Bottinger E, Susztak K: Poly(ADP-ribose) polymerase inhibitors ameliorate nephropathy of type 2 diabetic Leprdb/db mice. Diabetes 2006;55:3004-3012

56. Brownlee M: The Pathobiology of Diabetic Complications: A Unifying Mechanism. Diabetes 2005;54:1615-1625

57. Sinha-Hikim I, Shen R, Nzenwa I, Gelfand R, Mahata S, Sinha-Hikim A: Minocycline suppresses oxidative stress and attenuates fetal cardiac myocyte apoptosis triggered by in utero cocaine exposure. Apoptosis 2011;16:563-573

58. Beneke S, Cohausz O, Malanga M, Boukamp P, Althaus F, Bürkle A: Rapid regulation of telomere length is mediated by poly(ADP-ribose) polymerase-1. Nucleic Acids Research 2008;36:6309-6317

59. Howitz KT, Bitterman KJ, Cohen HY, Lamming DW, Lavu S, Wood JG, Zipkin RE, Chung P, Kisielewski A, Zhang LL, Scherer B, Sinclair DA: Small molecule activators of sirtuins extend Saccharomyces cerevisiae lifespan. Nature 2003;425:191-196

60. Suh Y, Afaq F, Johnson JJ, Mukhtar H: A plant flavonoid fisetin induces apoptosis in colon cancer cells by inhibition of COX2 and Wnt/EGFR/NF-KB-signaling pathways. Carcinogenesis 2009;30:300-307

61. Kim SR, Park JH, Lee ME, Park JS, Park SC, Han JA: Selective COX-2 inhibitors modulate cellular senescence in human dermal fibroblasts in a catalytic activity-independent manner. Mechanisms of Ageing and Development 2008;129:706-713

62. Blasco MA: The epigenetic regulation of mammalian telomeres. Nat Rev Genet 2007;8:299-309

63. Guan JZ, Guan WP, Maeda T, Makino N: The Subtelomere of Short Telomeres is Hypermethylated in Alzheimer's Disease. Aging Dis 2012;3:164-170

64. Maeda T, Guan JZ, Oyama J-i, Higuchi Y, Makino N: Aging-Associated Alteration of Subtelomeric Methylation in Parkinson's Disease. The Journals of Gerontology Series A: Biological Sciences and Medical Sciences 2009;64A:949-955

65. Caiafa P, Guastafierro T, Zampieri M: Epigenetics: poly(ADP-ribosyl)ation of PARP-1 regulates genomic methylation patterns. FASEB J 2009;23:672-678

66. Caiafa P, Zlatanova J: CCCTC-binding factor meets poly(ADP-ribose) polymerase-1. J Cell Physiol 2009;219:265-270

67. Reale A, Matteis GD, Galleazzi G, Zampieri M, Caiafa P: Modulation of DNMT1 activity by ADP-ribose polymers. Oncogene 2005;24:13-19

68. Lee WJ, Shim J-Y, Zhu BT: Mechanisms for the Inhibition of DNA Methyltransferases by Tea Catechins and Bioflavonoids. Molecular Pharmacology 2005;68:1018-1030 
Chapter 3

\section{Protective pleiotropic effect of flavonoids on $\mathrm{NAD}^{+}$levels in endothelial cells during high glucose}

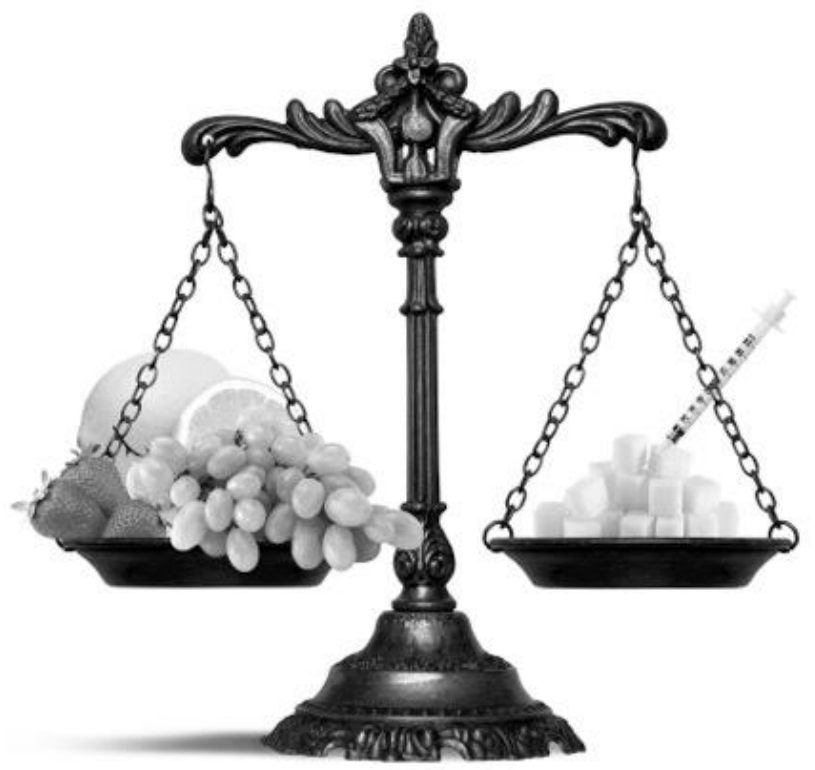

Daniëlle M.P.H.J. Boesten

Saskia N.I. von Ungern-Sternberg

Gertjan J.M. den Hartog

Aalt Bast 


\section{Abstract}

Background: $\mathrm{NAD}^{+}$is important for oxidative metabolism by serving as an electron transporter. Hyperglycemia decreases $\mathrm{NAD}^{+}$levels by activation of the polyol pathway and by overactivation of poly(ADP-ribose)-polymerase (PARP).

Methods: We examined the protective role of three structurally related flavonoids (rutin, quercetin and flavone) during high glucose conditions in an in vitro model using human umbilical vein endothelial cells (HUVECs). Additionally we assessed the ability of these flavonoids to inhibit aldose reductase enzyme activity.

Results: We have previously shown that flavonoids can inhibit PARP activation. Extending these studies, we here provide evidence that flavonoids are also able to protect endothelial cells against a high glucose induced decrease in $\mathrm{NAD}^{+}$. In addition, we established that flavonoids are able to inhibit aldose reductase, the key enzyme in the polyol pathway.

Conclusions: We conclude that this protective effect of flavonoids on $\mathrm{NAD}^{+}$levels is a combination of the flavonoids ability to inhibit both PARP activation as well as aldose reductase enzyme activity.

General significance: This study shows that flavonoids, by a combination of effects, maintain the redox state of the cell during hyperglycemia. This mode of action enables flavonoids to ameliorate diabetic complications. 


\section{Introduction}

Worldwide more almost 400 million people suffer from diabetes. This number will only grow due to the rapid increase in the incidence of the disease caused by population growth, aging, urbanization and increasing prevalence of obesity and physical inactivity (1). A hallmark of diabetes is hyperglycemia (2). A number of epidemiological studies have shown a relationship between hyperglycemia and an increased risk of cardiovascular diseases, including microvascular pathologies in the eye, kidney and peripheral nerves. As a consequence, diabetes is a leading cause of blindness, renal disease and a variety of debilitating neuropathies (e.g. diabetic foot) $(3 ; 4)$.

Nicotinamide adenine dinucleotide (NAD) is found in all living cells in an oxidized form $\left(N A D^{+}\right)$and a reduced form (NADH). The main function of NAD in cells is modulating cellular redox status by carrying electrons from one reaction to another. Additionally, it is also involved in other cellular processes (e.g. acting as a substrate for enzymes involved in posttranslational modification) (5). Hyperglycemia decreases $\mathrm{NAD}^{+}$levels by an increased flux of glucose through the polyol pathway. This pathway becomes active when intracellular glucose levels are elevated (6). During normoglycemia only 3\% of all glucose will enter the polyol pathway. Most of the glucose will be phosphorylated to glucose-6-phosphate by hexokinase. However, under hyperglycemic conditions ten times more glucose enters the polyol pathway (7), mainly due to a saturation of hexokinase (8). Aldose reductase, the first and rate-limiting enzyme in the pathway, reduces glucose to sorbitol using NADPH as a cofactor. Then, sorbitol is reduced to fructose by sorbitol dehydrogenase which uses $\mathrm{NAD}^{+}$as a cofactor. The osmotic stress that accompanies sorbitol accumulation and the redox imbalance following the depletion of NADPH and $\mathrm{NAD}^{+}$contributes to cell damage and organ injury, ultimately leading to cataract genesis, neuropathy and other diabetic complications (9-11).

Poly(ADP-ribose)-polymerase (PARP) activation can also lead to $\mathrm{NAD}^{+}$depletion. The nuclear enzyme PARP has been implicated in the regulation of many important cellular functions like DNA repair, gene transcription, cell cycle progression, cell death, chromatin function and genomic stability (12). PARP detects and signals single-strand DNA breaks (SSB), which can be induced by hyperglycemia. Upon detection of a SSB, PARP binds to the DNA and synthesizes a poly(ADP-ribose) (PAR) chain as a signal for DNA repair enzymes. $N A D^{+}$is required as a substrate for the synthesis of these PAR monomers. Overactivation of PARP therefore depletes 
cellular $\mathrm{NAD}^{+}$stores (13). Several studies have suggested an important role of PARP activation in the pathogenesis of diabetic complications like nephropathy, neuropathy and retinopathy (14-16).

Previously we have established that dietary flavonoids inhibit PARP both in vitro as well as in vivo (17-19). Flavonoids are polyphenolic compounds which are found in fruits, vegetables and plant-derived products like red wine and tea (18). Flavonoids have been shown to display positive health effects, e.g. reduced risks for cardiovascular and chronic inflammatory diseases (20-23), which have been ascribed to their antioxidant and anti-inflammatory properties $(22 ; 24)$. We now studied the effect of high glucose with or without flavonoids on $\mathrm{NAD}^{+}$levels in endothelial cells. In addition we determined whether three structurally related flavonoids are also able to inhibit aldose reductase, the most important enzyme of the polyol pathway.

\section{Material and methods}

\section{Chemicals}

All chemicals were purchased from Sigma-Aldrich (Steinheim, Germany) unless stated otherwise. F12K medium, Hank's Balanced Salt Solution (HBSS), trypsinEDTA, non-heat inactivated fetal calf serum (FCS), and penicillin/streptomycin were obtained from Gibco (Breda, The Netherlands). Endothelial cell growth supplement (ECGS) was obtained from BD Bioscience (Breda, The Netherlands). Heparin was purchased from Leo Pharmaceuticals (Amsterdam, The Netherlands).

\section{Cell culture}

Human Umbilical Vein Endothelial (HUVEC) cells (CRL-1730) were obtained from ATCC. HUVECs were cultured in F12K medium with $10 \%$ FCS, $1 \%$ penicillin/streptomycin, $0.05 \mathrm{mg} / \mathrm{ml}$ endothelial cell growth supplement (ECGS) and $0.1 \mathrm{mg} / \mathrm{ml}$ heparin. Cells were maintained in collagen coated flasks at $37^{\circ} \mathrm{C}$ in a $5 \%$ $\mathrm{CO}_{2}$ atmosphere. For experiments, cells were seeded in 6 or 96 well plates and allowed to attach overnight. Next, medium was removed and cells were washed with HBSS. Additionally, fresh medium was added containing glucose ( $30 \mathrm{mM}$ final concentration) or vehicle (medium) and flavonoids (5 $\mu \mathrm{M}$ final concentration), sorbinil (0.5 $\mu \mathrm{M}$ final concentration) or its vehicle (DMSO).

\section{Gene expression analysis}

RNA was isolated from Qiazol suspended cells according to the manufacturer's protocol and quantified spectrophotometrically with a Nanodrop. RNA (500 ng) was reverse transcribed using iScript ${ }^{\mathrm{TM}} \mathrm{CDNA}$ synthesis kit (Biorad, Veenendaal, The 
Netherlands). Next, real time PCR was performed with a Biorad MylQ iCycler Single Color RT-PCR detection system using Sensimix ${ }^{T M}$ Plus SYBR and Fluorescein (Quantace-Bioline, Alphen a/d Rijn, The Netherlands), $5 \mu$ diluted (10x) cDNA and $0.3 \mu \mathrm{M}$ primers in a total volume of $25 \mu \mathrm{l}$. PCR was conducted as follows: denaturation at $95^{\circ} \mathrm{C}$ for 10 minutes, followed by 40 cycles of $95^{\circ} \mathrm{C}$ for 15 seconds and $60^{\circ} \mathrm{C}$ for 45 seconds. After PCR, a melt curve $\left(60-95^{\circ} \mathrm{C}\right)$ was produced for product identification and purity. $\beta$-actin was included as internal control. Primer sequences are shown in table 1 . Data were analysed using the MylQ software system (BioRad) and were expressed as relative gene expression (fold change) using the $2^{\Delta \Delta \mathrm{Ct}}$ method.

Table 1: Primer sequences for genes used for gene expression analysis

\begin{tabular}{lll}
\hline Gene & Forward (5' to $\mathbf{3}^{\prime}$ ) & Reverse (5' to $\mathbf{3}^{\prime}$ ) \\
\hline Beta-actin ( $\beta$-actin) & CCTGGCACCCAGCACAAT & GCCGATCCACACGGAGTACT \\
Aldose reductase & TACACATGGGCACAGTCGAT & GGGGTTGGGTACCTGGAA \\
PARP-1 & GCCAGTTCAGGACCTCATCAA & CGGCCTGGATCTGCCTTT \\
\hline
\end{tabular}

\section{Determination of $\mathrm{NAD}^{+}$levels}

Cell were lysed with $1 \%$ dodecyltrimethylammonium bromide (DTAB) in $0.2 \mathrm{~N}$ $\mathrm{NaOH}$. To ensure only $\mathrm{NAD}^{+}$levels were measured $0.4 \mathrm{M} \mathrm{HCl}$ was added and samples were incubated at $60^{\circ} \mathrm{C}$ for 15 minutes. Afterwards, cells were incubated at room temperature for 10 minutes and $0.5 \mathrm{M}$ Trizma base was added to the cells after which $\mathrm{NAD}^{+}$levels were determined with the NAD ${ }^{+} / \mathrm{NADH}$ cell based assay kit from Cayman Chemical (Ann Arbor, MI, USA).

\section{Preperation of lens aldose reductase}

Porcine lenses were used as a source of aldose reductase enzyme. Porcine eyes were obtained from a local slaughterhouse. Lenses were removed and stored at $20^{\circ} \mathrm{C}$ until use. Lens homogenate was prepared fresh for every experiment. Lenses were homogenized in $1.25 \mathrm{ml}$ homogenization buffer ( $20 \mathrm{mM}$ potassium phosphate buffer, pH 7.5 containing $0.5 \mathrm{mM}$ EDTA and $5 \mathrm{mM}$ 2-mercaptoethanol). The homogenate was centrifuged at $10.000 \times \mathrm{g}$ for 10 minutes at $4^{\circ} \mathrm{C}$.

\section{Aldose reductase assay}

Aldose reductase activity was determined spectrophotometrically. The reaction mixture $(0.7 \mathrm{ml})$ contained $30 \mathrm{mM}$ potassium phosphate buffer $(\mathrm{pH} 6.2), 0.2 \mathrm{mM}$ $\mathrm{NADPH}, 0.2 \mathrm{M}$ lithium sulphate, the substrate DL-glyceraldehyde (0-2 mM). Flavonoids (flavone, quercetin and rutin) were added to the reaction mixture (final concentration 0.5 or $5 \mu \mathrm{M}$ ). As a positive control, the known aldose reductase 


\section{Chapter 3}

inhibitor sorbinil was used in a concentration of $0.5 \mu \mathrm{M}$. Reaction was initiated by addition of NADPH. The consumption of NADPH was followed by the decrease in absorbance at $340 \mathrm{~nm}$ for 5 minutes at $37^{\circ} \mathrm{C}$.

\section{Statistical analysis}

The effect of HG incubation and effects of flavonoids were tested using Student's ttest for independent samples or the Mann-Whitney $U$ test when not normally distributed. P-values $<0.05$ were considered statistically significant and $p$-values $<0.1$ were considered statistical trends. Statistical analyses were analyzed with SPSS for Windows (version 20.0; SPSS Inc., Chicago, IL, USA).

\section{Results}

In figure 1, the effect of incubating HUVECs with $30 \mathrm{mM}$ of glucose on gene expression of aldose reductase and PARP-1 is presented. It is visible that both aldose reductase and PARP-1 have a significant higher expression after 24 hours incubation compared to normal glucose. When flavonoids are coincubated during these 24 hours, there is no effect on aldose reductase expression compared to only high glucose incubation. Only quercetin seems to lower PARP-1 expression compared to high glucose incubation.
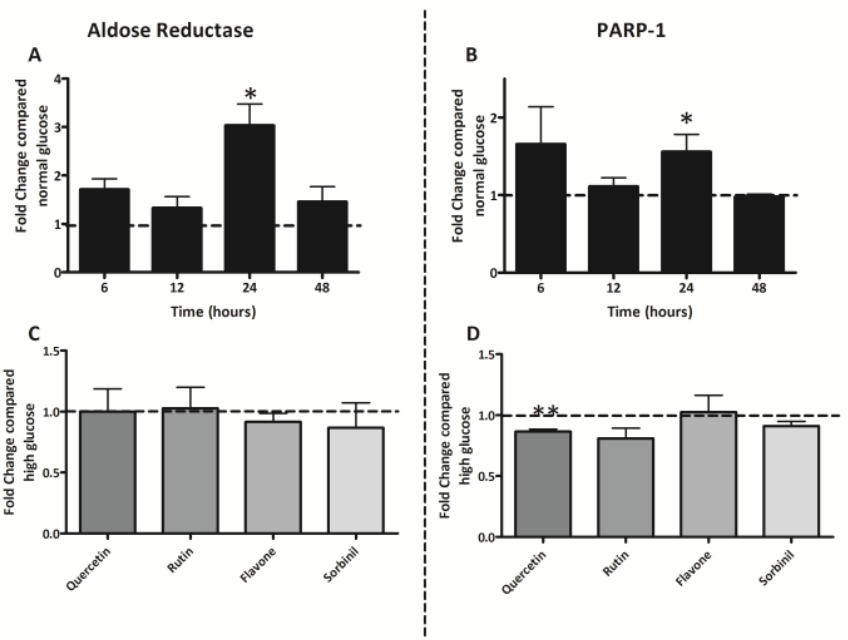

Figure 1: Effect of incubation with $30 \mathrm{mM}$ glucose on the expression of aldose reductase (A) and PARP-1 (B) after several incubation times. Effect of addition of flavonoids (compared to high glucose incubation) after 24 hours incubation is shown in C (Aldose Reductase) and D (PARP-1). Data are expressed as mean \pm standard error from three independent experiments. *: $\mathrm{p}<0.05$ compared to normal glucose incubation; ** $\mathrm{p}<0.05$ compared to incubation with high glucose alone. 


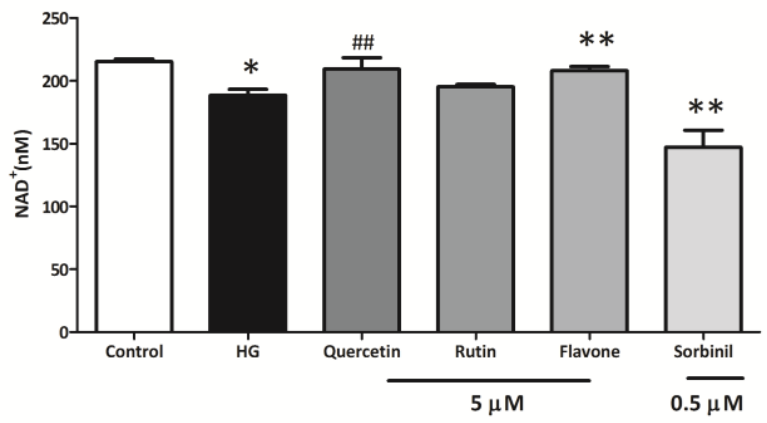

Figure 2: Effect of 24 hour incubation with 7 (control) or $30 \mathrm{mM}(\mathrm{HG})$ glucose on the NAD+ level of HUVECs with or without coincubation with flavonoids. Data are expressed as mean \pm standard error from four independent experiments. *: $p<0.05$ compared to control; ** $p<0.05$ compared to incubation with high glucose alone; \#\# $p<0.1$ compared to incubation with high glucose alone.

The effect of incubation with $30 \mathrm{mM}$ glucose on the $\mathrm{NAD}^{+}$status of HUVECs is depicted in figure 2. High glucose incubation leads to a significant decrease in $\mathrm{NAD}^{+}$ levels after 24 hours. This decrease is attenuated when the cells are coincubated with flavone or quercetin (trend) but not with rutin. Incubation with the known aldose reductase inhibitor sorbinil led to an even larger decrease in $\mathrm{NAD}^{+}$levels.

Quercetin, rutin and flavone at a concentration of $5 \mu \mathrm{M}$ decreased the $\mathrm{V}_{\max }$ of the aldose reductase catalysed conversion of DL-glyceraldehyde to glycerol. Sorbinil was used as a control and decreased both the $\mathrm{V}_{\max }$ and $\mathrm{K}_{\mathrm{m}}$ at a concentration of 0.5 $\mu \mathrm{M}$. Rutin also showed a small but significant decrease of $K_{m}$ compared to the control (table 2 and figure 3).

Table 2: Kinetics of porcine aldose reductase in the absence and presence of flavonoids.

Data are expressed as mean \pm standard deviation of at least three separate experiments. *: $p<0.05$ compared to control.

\begin{tabular}{lcc}
\hline & $\boldsymbol{K}_{\mathbf{m}}(\mathbf{m M})$ & $\begin{array}{c}\mathbf{V}_{\max } \\
(\mu \mathrm{M} \text { NADPH oxidized/min/mg protein) }\end{array}$ \\
\hline Control & $0.065 \pm 0.02$ & $1.68 \pm 0.31$ \\
$0.5 \mu \mathrm{M}$ Sorbinil & $0.038 \pm 0.003^{*}$ & $0.67 \pm 0.06^{*}$ \\
$0.5 \mu$ M Flavone & $0.071 \pm 0.04$ & $1.61 \pm 0.18$ \\
$5 \mu$ M Flavone & $0.058 \pm 0.02$ & $1.25 \pm 0.04^{*}$ \\
$0.5 \mu$ M Quercetin & $0.084 \pm 0.01$ & $1.78 \pm 0.33$ \\
$5 \mu$ M Quercetin & $0.062 \pm 0.02$ & $1.02 \pm 0.18^{*}$ \\
$0.5 \mu$ M Rutin & $0.056 \pm 0.02$ & $1.53 \pm 0.29$ \\
$5 \mu$ M Rutin & $0.034 \pm 0.01^{*}$ & $0.81 \pm 0.10^{*}$ \\
\hline
\end{tabular}




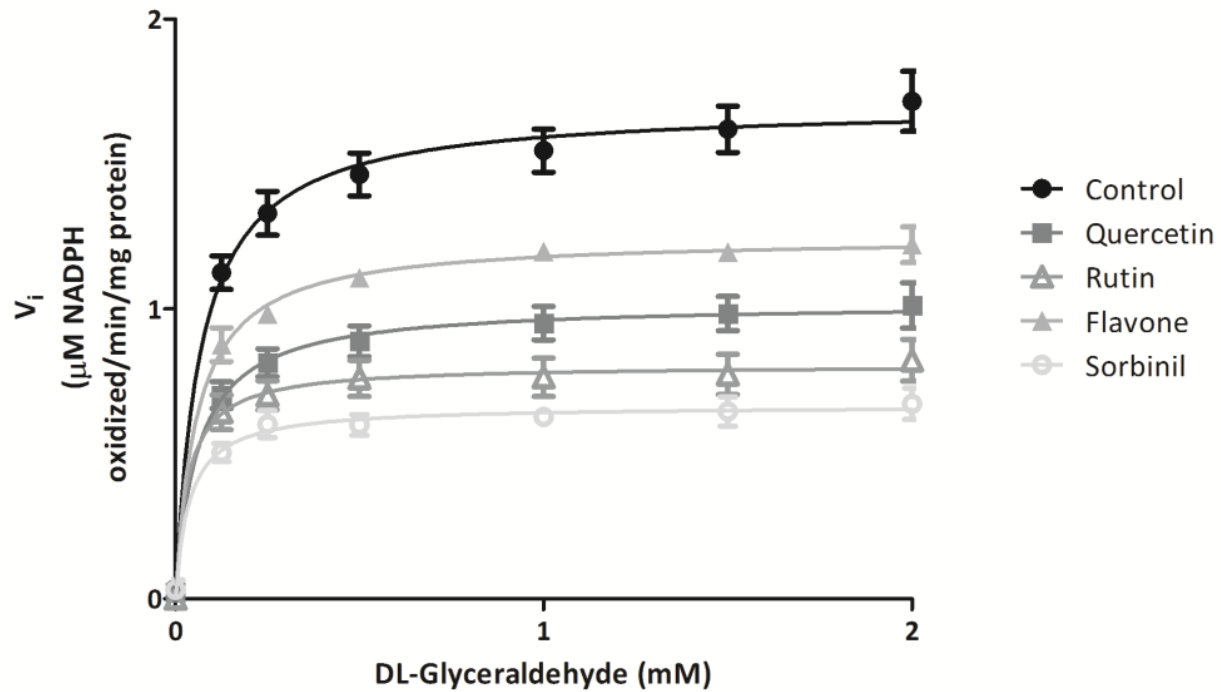

Figure 3: An example of a Michaelis Menten plot of aldose reductase in absence (filled circles) and presence of $5 \mu \mathrm{M}$ quercetin (filled squares), $5 \mu \mathrm{M}$ rutin (open triangles), $5 \mu \mathrm{M}$ flavone (filled triangles) or $0.5 \mu \mathrm{M}$ sorbinil (open circles). Data are expressed as mean \pm standard error of at least three experiments.

\section{Discussion}

In epidemiological studies, the intake of flavonoids has been related to a reduced risk for various diseases, including diabetes $(23 ; 25 ; 26)$. Many complications that arise from diabetes are attributed to a redox imbalance. In previous studies we established that flavonoids were able to attenuate $\mathrm{NAD}^{+}$depletion by inhibiting PARP overactivation both in vitro as well as in vivo (17-19). Extending these studies, we here provide evidence that flavonoids are also able to protect endothelial cells against a decrease in $\mathrm{NAD}^{+}$due to high glucose. In addition we show that flavonoids are able to inhibit the key enzyme of the polyol pathway, aldose reductase.

In this study three structurally related flavonoids were studied. Flavone, the core structure of the flavonoid subgroup flavones, a compound that is present in many cereal grains as well as in dill weed (27). Quercetin, one of the most prominent dietary flavonoids present in many foods including citrus fruit and berries (28) and rutin, a glycoside of quercetin which is found in buckwheat (29).

Gene expression of aldose reductase and PARP was investigated in endothelial cells exposed to $30 \mathrm{mM}$ glucose. A higher expression of aldose reductase in peripheral blood mononuclear cells has been linked to an increased risk for kidney disease in 
diabetic patients (30). Furthermore, in transgenic mice, it was found that human aldose reductase expression increased atherosclerosis lesion size which could be attenuated by aldose reductase inhibitors $(31 ; 32)$. An increase in PARP mRNA expression was found in patients with type 2 diabetes and microangiopathy (33). We found an increase in the expression of both genes when endothelial cells were exposed to $30 \mathrm{mM}$ glucose for 24 hours. Coincubation with flavonoids or sorbinil did not affect this increase.

$\mathrm{NAD}^{+}$is a co-factor in numerous critical oxidation reactions. Because of the involvement in redox signalling, $\mathrm{NAD}^{+}: \mathrm{NADH}$ is regarded as one of the most important redox couples of the cells and therefore an important determinant of redox status of cells. We found a slight decrease in $\mathrm{NAD}^{+}$levels after incubating HUVECs with $30 \mathrm{mM}$ glucose for 24 hours. This change is most likely a combination of the two previously described pathways; a decrease in $\mathrm{NAD}^{+}$due to activation of the polyol pathway and overactivation of PARP-1. Therefore we also investigated the potential of flavonoids to inhibit aldose reductase.

The flavonoids' ability to inhibit aldose reductase has been described previously (34). In our study, it was found that all tested flavonoids were able to inhibit aldose reductase enzyme activity at a concentration of $5 \mu \mathrm{M}$. Quercetin and flavone appear to be non-competitive inhibitors because only the $V_{\max }$ of the reaction is decreased. Conversely, rutin not only decreased the $V_{\text {max }}$, it also decreased the $K_{M}$ slightly. This would indicate a slightly higher reaction rate at very low substrate concentrations but a much lower rate at higher substrate concentrations. Rutin contains rutinose, which is a disaccharide composed of rhamnose and glucose. The latter is a substrate of aldose reductase, however the affinity of aldose reductase for DL-glyceraldehyde is higher (7). Rutin as a competitive inhibitor is further supported by the results of sorbinil, which is a known competitive inhibitor of aldose reductase (35). Sorbinil was tested at a lower concentration ( $0.5 \mu \mathrm{M})$ but shows the same results as rutin, a decrease in both the $V_{\max }$ as well as $\mathrm{K}_{\mathrm{M}}$. Of the tested flavonoids, rutin showed the strongest inhibition, while flavone had the least effect. This is contrary to their capacity to inhibit PARP overactivation, where flavone is the most potent inhibitor and rutin is not able to inhibit PARP (Table 3 ). In both reactions quercetin is an intermediate inhibitor compared to rutin and flavone. 
Table 3: Overview of structure and PARP inhibiting capacity of flavonoids used in this study $(17 ; 18)$.

Name Flavone
$\begin{aligned} & \text { PARP } \\ & \text { inhibiting } \\ & \text { capacity }\end{aligned}$
concentrations

These findings indicate that the overactivation of PARP-1 plays a larger role than the polyol pathway in the decrease of $\mathrm{NAD}^{+}$levels in HUVECs. When cells were coincubated with flavonoids, we observed that flavone was able to attenuate the decrease in $\mathrm{NAD}^{+}$concentration. Flavone is the most potent PARP-1 inhibitor but did not have a big effect on aldose reductase activity. This finding is also supported by the observation that rutin, the most potent aldose reductase activity inhibitor, did not show an effect on $\mathrm{NAD}^{+}$levels. Quercetin, an average inhibitor of both pathways, showed a trend towards increasing $\mathrm{NAD}^{+}$levels to normal. The influence of the polyol pathway on the lower $\mathrm{NAD}^{+}$level seems to be small. Most likely the activation of this pathway has a more pronounced effect on the levels of NADPH. By lowering the levels of this essential cofactor for glutathione, the cells get more susceptible to oxidative stress (36). This in turn can lead to more reactive oxygen species that can damage DNA, inducing activation of PARP-1, which subsequently can lead to a decrease in NAD ${ }^{+}$levels as we observed in HUVECs. This might also be the reason why coincubation with sorbinil leads to an extra decrease in $\mathrm{NAD}^{+}$ levels in HUVECs. By inhibiting the aldose reductase almost completely, unlike the flavonoids which show a mild inhibition, other pathways involved in the pathogenesis of diabetic complications may become more activated (e.g. activation PKC), this then can lead to more oxidative stress and activation of PARP-1 (36). 


\section{Conclusion}

We conclude that flavonoids are able to exert pleiotropic protective effects under high glucose conditions (figure 4).

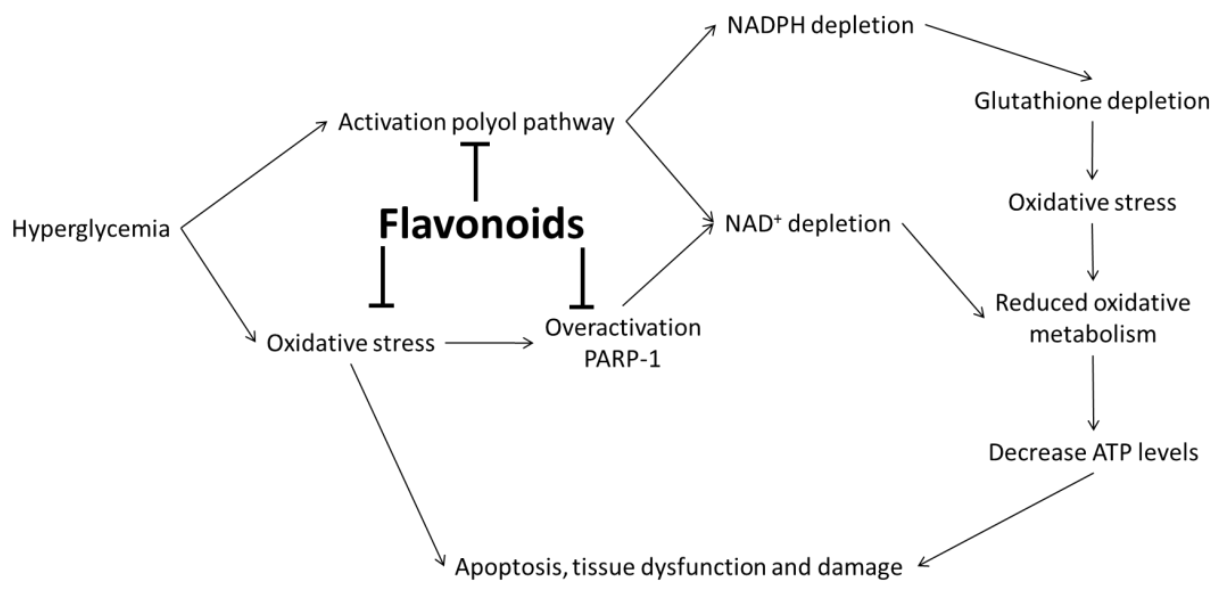

Figure 4: Flavonoids can protect cells under hyperglycemic stress in several ways. First, flavonoids are able to inhibit overactivation of PARP-1, preventing a decrease in $\mathrm{NAD}^{+}$levels. Furthermore, flavonoids are able to inhibit aldose reductase activity, preventing an additional decrease in $\mathrm{NAD}^{+}$and NADH levels. Also, because of their antioxidant properties, flavonoids are able to prevent damaging effects of oxidative stress. By a combination of all these effects flavonoids are able to protect cells against high glucose induced damage.

We observed that flavonoids were able to inhibit overactivation of PARP-1, thereby preventing a fall in $\mathrm{NAD}^{+}$levels. Furthermore we observed that flavonoids are able to inhibit aldose reductase activity, preventing an additional decrease in $\mathrm{NAD}^{+}$ levels. Moreover, because of the known antioxidant properties of flavonoids they are also able to prevent the deleterious effects of reactive oxygen species which can be formed when a redox imbalance is present. In conclusion, the combination of all these effects is most likely the reason why flavonoids were able to protect endothelial cells against a high glucose induced drop in $\mathrm{NAD}^{+}$levels in an in vitro system. 


\section{References}

1. IDF Diabetes Atlas, 6th edn. [article online], 2013. Available from http://www.idf.org/diabetesatlas.

2. Crimi E, Ignarro LJ, Napoli C: Microcirculation and oxidative stress. Free Radic Res 2007;41:1364-1375

3. Aronson D: Hyperglycemia and the pathobiology of diabetic complications. Adv Cardiol 2008;45:1-16

4. Brownlee M: Biochemistry and molecular cell biology of diabetic complications. Nature 2001;414:813-820

5. Ido Y: Pyridine nucleotide redox abnormalities in diabetes. Antioxid Redox Signal 2007;9:931-942

6. Gabbay KH: The sorbitol pathway and the complications of diabetes. N Engl J Med 1973;288:831-836

7. Bhatnagar A, Srivastava SK: Aldose reductase: congenial and injurious profiles of an enigmatic enzyme. Biochem Med Metab Biol 1992;48:91-121

8. Yabe-Nishimura C: Aldose reductase in glucose toxicity: a potential target for the prevention of diabetic complications. Pharmacol Rev 1998;50:21-33

9. Oyama T, Miyasita $\mathrm{Y}$, Watanabe $\mathrm{H}$, Shirai $\mathrm{K}$ : The role of polyol pathway in high glucoseinduced endothelial cell damages. Diabetes Res Clin Pract 2006;73:227-234

10. Reddy GB, Satyanarayana A, Balakrishna N, Ayyagari R, Padma M, Viswanath K, Petrash JM: Erythrocyte aldose reductase activity and sorbitol levels in diabetic retinopathy. Mol Vis 2008;14:593-601

11. Srivastava SK, Ramana KV, Bhatnagar A: Role of aldose reductase and oxidative damage in diabetes and the consequent potential for therapeutic options. Endocr Rev 2005;26:380392

12. Pacher P, Szabo C: Role of the peroxynitrite-poly(ADP-ribose) polymerase pathway in human disease. Am J Pathol 2008;173:2-13

13. Moonen HJ, Geraets L, Vaarhorst A, Bast A, Wouters EF, Hageman GJ: Theophylline prevents NAD+ depletion via PARP-1 inhibition in human pulmonary epithelial cells. Biochem Biophys Res Commun 2005;338:1805-1810

14. Li F, Szabo C, Pacher P, Southan GJ, Abatan OI, Charniauskaya T, Stevens MJ, Obrosova IG: Evaluation of orally active poly(ADP-ribose) polymerase inhibitor in streptozotocindiabetic rat model of early peripheral neuropathy. Diabetologia 2004;47:710-717

15. Minchenko AG, Stevens MJ, White L, Abatan OI, Komjati K, Pacher P, Szabo C, Obrosova IG: Diabetes-induced overexpression of endothelin-1 and endothelin receptors in the rat renal cortex is mediated via poly(ADP-ribose) polymerase activation. FASEB J 2003;17:15141516

16. Szabo C, Biser A, Benko R, Bottinger E, Susztak K: Poly(ADP-ribose) polymerase inhibitors ameliorate nephropathy of type 2 diabetic Leprdb/db mice. Diabetes 2006;55:3004-3012

17. Geraets L, Moonen HJ, Brauers K, Gottschalk RW, Wouters EF, Bast A, Hageman GJ: Flavone as PARP-1 inhibitor: its effect on lipopolysaccharide induced gene-expression. Eur J Pharmacol 2007;573:241-248

18. Geraets L, Moonen HJ, Brauers K, Wouters EF, Bast A, Hageman GJ: Dietary flavones and flavonoles are inhibitors of poly(ADP-ribose)polymerase- 1 in pulmonary epithelial cells. J Nutr 2007;137:2190-2195

19. Weseler AR, Geraets L, Moonen HJ, Manders RJ, van Loon LJ, Pennings HJ, Wouters EF, Bast A, Hageman GJ: Poly (ADP-ribose) polymerase-1-inhibiting flavonoids attenuate cytokine release in blood from male patients with chronic obstructive pulmonary disease or type 2 diabetes. J Nutr 2009;139:952-957 
20. Hertog MG, Feskens EJ, Hollman PC, Katan MB, Kromhout D: Dietary antioxidant flavonoids and risk of coronary heart disease: the Zutphen Elderly Study. Lancet 1993;342:1007-1011

21. Nijveldt RJ, van Nood E, van Hoorn DE, Boelens PG, van Norren $K$, van Leeuwen PA: Flavonoids: a review of probable mechanisms of action and potential applications. Am J Clin Nutr 2001;74:418-425

22. Scalbert A, Johnson IT, Saltmarsh M: Polyphenols: antioxidants and beyond. The American Journal of Clinical Nutrition 2005;81:215S-217S

23. Bahadoran Z, Mirmiran P, Azizi F: Dietary polyphenols as potential nutraceuticals in management of diabetes: a review. J Diabetes Metab Disord 2013;12:43

24. Rice-Evans CA, Miller NJ, Paganga G: Structure-antioxidant activity relationships of flavonoids and phenolic acids. Free Radic Biol Med 1996;20:933-956

25. Hertog MG, Hollman PC, Katan MB, Kromhout D: Intake of potentially anticarcinogenic flavonoids and their determinants in adults in The Netherlands. Nutr Cancer 1993;20:21-29

26. Wedick NM, Pan A, Cassidy A, Rimm EB, Sampson L, Rosner B, Willett W, Hu FB, Sun Q, van Dam RM: Dietary flavonoid intakes and risk of type 2 diabetes in US men and women. Am J Clin Nutr 2012;95:925-933

27. Wenzel U, Kuntz S, Brendel MD, Daniel H: Dietary flavone is a potent apoptosis inducer in human colon carcinoma cells. Cancer Res 2000;60:3823-3831

28. Hakkinen SH, Karenlampi SO, Heinonen IM, Mykkanen HM, Torronen AR: Content of the flavonols quercetin, myricetin, and kaempferol in 25 edible berries. J Agric Food Chem 1999;47:2274-2279

29. Kreft S, Knapp M, Kreft I: Extraction of rutin from buckwheat (Fagopyrum esculentumMoench) seeds and determination by capillary electrophoresis. J Agric Food Chem 1999;47:4649-4652

30. Shah VO, Dorin RI, Sun Y, Braun M, Zager PG: Aldose reductase gene expression is increased in diabetic nephropathy. J Clin Endocrinol Metab 1997;82:2294-2298

31. Vikramadithyan RK, Hu Y, Noh HL, Liang CP, Hallam K, Tall AR, Ramasamy R, Goldberg IJ: Human aldose reductase expression accelerates diabetic atherosclerosis in transgenic mice. J Clin Invest 2005;115:2434-2443

32. Vedantham S, Noh H, Ananthakrishnan R, Son N, Hallam K, Hu Y, Yu S, Shen X, Rosario R, Lu Y, Ravindranath T, Drosatos K, Huggins LA, Schmidt AM, Goldberg IJ, Ramasamy R: Human aldose reductase expression accelerates atherosclerosis in diabetic apolipoprotein $\mathrm{E}$-/- mice. Arterioscler Thromb Vasc Biol 2011;31:1805-1813

33. Adaikalakoteswari A, Rema M, Mohan V, Balasubramanyam M: Oxidative DNA damage and augmentation of poly(ADP-ribose) polymerase/nuclear factor-kappa B signaling in patients with type 2 diabetes and microangiopathy. Int J Biochem Cell Biol 2007;39:16731684

34. Varma SD, Mikuni I, Kinoshita JH: Flavonoids as inhibitors of lens aldose reductase. Science 1975;188:1215-1216

35. Liu SQ, Bhatnagar A, Srivastava SK: Does sorbinil bind to the substrate binding site of aldose reductase? Biochem Pharmacol 1992;44:2427-2429

36. Brownlee M: The Pathobiology of Diabetic Complications: A Unifying Mechanism. Diabetes 2005;54:1615-1625 
Chapter 4

\title{
Effect of
}

\section{$\mathbf{N}^{\varepsilon}$-carboxymethyllysine on oxidative stress and the glutathione system in beta cells}

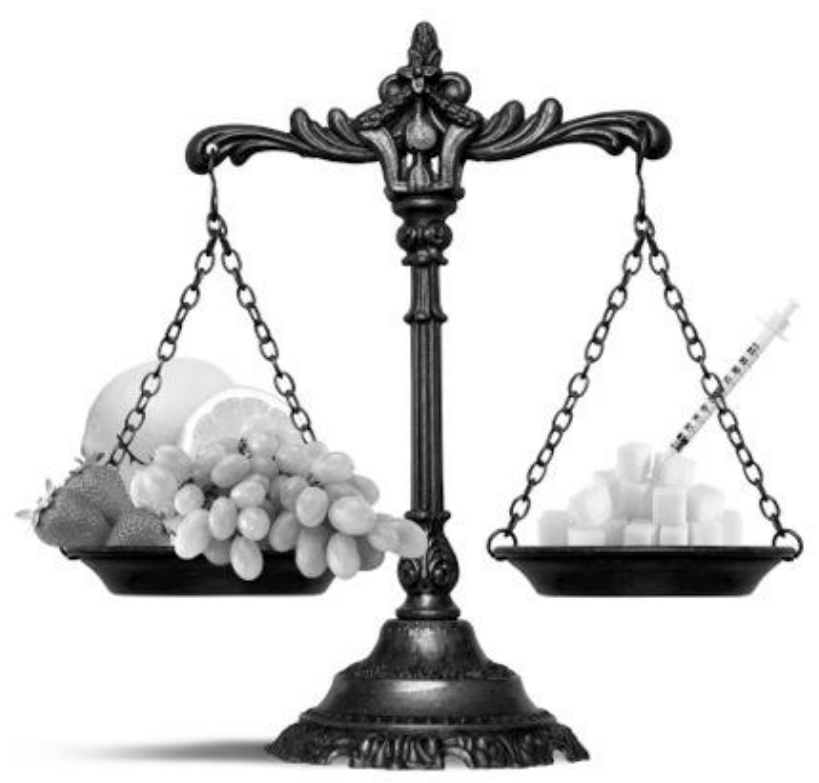

\author{
Daniëlle M.P.H.J. Boesten \\ Atlanta G.I.M. Elie \\ Marie-José Drittij-Reijnders \\ Gertjan J.M. den Hartog \\ Aalt Bast
}

Toxicology Reports; Accepted for publication 


\section{Abstract}

One of the pathways involved in the pathogenesis of diabetic complications is the formation of excessive levels of advanced glycation end (AGE) products. $N^{\varepsilon}$ carboxymethyllysine (CML) is one of the best-characterized AGEs. Because little is known about the effects of AGEs on pancreatic beta cells, we investigated the effect of $\mathrm{CML}$ on human pancreatic cells and determined the activity and gene expression of glutathione system components. CML at a concentration of $0.5 \mathrm{mM}$ induced cell death in human pancreatic beta cells, which was accompanied by increased intracellular oxidative stress. No changes in the gene expression of the receptor for AGEs (RAGE) were found, although an increase in the level of a target cytokine of RAGE after CML exposure was observed. Additionally we found that CML lowered the levels of GSH and affected the activity and expression of other components of the glutathione system. These changes indicate that the cells are even more vulnerable for oxidative stress after exposure to CML. Since beta cells are low in antioxidant enzymes and repair for oxidized DNA, CML, but most likely also other AGEs, accelerates beta cell dysfunction and increases beta cell death during chronic hyperglycemia. 


\section{Introduction}

Hyperglycemia, which occurs during type 2 diabetes, is associated with oxidative stress (1). Formation of advanced glycation end products (AGEs) is one of the mechanisms that results in the increased formation of oxygen radicals. AGEs constitute a heterogeneous group of macromolecules formed by the nonenzymatic glycation of proteins, lipids and nucleic acids. AGEs can be ingested with food and are also formed in small amounts endogenously in the body as a consequence of normal metabolism (2). During prolonged hyperglycemia AGEs can contribute to diabetic complications by the formation of crosslinks in the basal membrane and accumulation of glycated proteins which alters cellular structure and protein functions. Furthermore, interaction with the receptor for AGE (RAGE) leads to the expression of pro-inflammatory genes like interleukin-8 (IL-8) and monocyte chemoattractant protein-1 (MCP-1) $(3 ; 4) . N^{\varepsilon}$-carboxymethyllysine $(\mathrm{CML})$ is one of the best-characterized AGEs. Elevated levels of serum CML have been associated with arterial stiffness and pose a higher risk of cardiovascular and all-cause mortality (5-7).

Pancreatic beta cells appear to be particularly vulnerable for oxidative stress. Expression and activity of the key antioxidant enzymes superoxide dismutase (SOD), catalase (CAT) and glutathione peroxidase (GPX) is low in beta cells compared to other cell types (8). Moreover, beta cells were found incapable to adapt their antioxidant enzyme activity in response to oxidative stress (9). In addition, it was shown that pancreatic islets possess low repair machinery for oxidized DNA (10). Although a lot of research has focused on the amount of antioxidant enzymes in pancreatic islets and the effect of overexpression of GPx, little is known about the levels and role of other components of the glutathione system in the beta cell.

Glutathione, a tripeptide ( $\gamma$-glutamylcysteinylglycine), is the major free thiol in most living cells and is involved in many biological processes. Within cells, GSH is found in both the reduced sulfhydryl form (GSH) and the glutathione disulfide oxidized form (GSSG). Under normal conditions, more than $90 \%$ of the glutathione pool is present in the reduced form. The balance between GSH and GSSG is tightly regulated in the cell, as a decrease in GSH can put the cell at risk for oxidative damage. An increased GSSG to GSH ratio is therefore often considered as an indicator of oxidative stress (11).

Glutathione has a diversity of crucial physiological roles, but it principally serves as an endogenous antioxidant. It functions as a cofactor for GPx, the major defense 
mechanism against potential toxic hydrogen peroxide and other peroxides (12). During the detoxification process of peroxides, GSSG is formed. GSH is regenerated from GSSG by the NADPH-dependent enzyme glutathione reductase (GR) (13). Additionally, glutathione S-transferase (GST) uses GSH as a substrate to form conjugates with electrophiles, resulting in more water soluble metabolites which are more readily excreted. Glutaredoxin $(G r x)$ utilizes the reducing power of glutathione to catalyze disulfide reductions in the presence of NADPH and GR. Grx is involved in regulation of various cellular functions, including electron transport and protein folding (14).

Because little is known about the effects of AGEs on pancreatic beta cells, we investigated the effect of $\mathrm{CML}$ on pancreatic cell viability and determined the activity and expression of components belonging to the glutathione system.

\section{Material and Methods}

\section{Chemicals}

All chemicals were purchased from Sigma-Aldrich (Steinheim, Germany) unless stated otherwise. CML was obtained from SyMO-Chem BV (Eindhoven, Netherlands). Roswell Park Memorial Institute (RPMI) 1640 medium, Hank's Balanced Salt Solution (HBSS), trypsin-EDTA (1x), non-heat inactivated fetal calf serum (FCS), and L-Glutamine were obtained from Gibco (Breda, The Netherlands).

\section{Cell culture}

The human pancreatic beta cell line $1.1 \mathrm{E7}$ (15) was obtained from HPA Culture Collections. Cells were cultured in RPMI 1640 medium with 10\% non-heat inactivated FCS and $2 \mathrm{mM} \mathrm{L-glutamine.} \mathrm{Cells} \mathrm{were} \mathrm{maintained} \mathrm{in} \mathrm{T75} \mathrm{flasks} \mathrm{at} 37^{\circ} \mathrm{C}$ in a $5 \% \mathrm{CO} 2$ atmosphere.

\section{MTT assay}

Cells were seeded at a density of 5000 cells per well in a 96-well plate and after overnight attaching, medium was removed and cells were washed with HBSS. CML was added to the plate in different concentrations (0-1 mM). Subsequently, cells were incubated for 24 hours. After treatment, supernatant was removed and cells were washed with PBS. Next, $100 \mu \mathrm{l}$ of MTT solution $(0.5 \mathrm{mg} / \mathrm{ml}$ in culture medium) was added and cells were incubated for 1 hour at $37^{\circ} \mathrm{C}$. After incubation, the plate was washed with PBS and the formazan crystals were dissolved in $200 \mu \mathrm{I}$ DMSO. Cells were incubated for 30 minutes after which the absorbance at $540 \mathrm{~nm}$ was measured spectrophotometrically using a microplate reader. Relative viability is expressed as a percentage relative to untreated cells. 


\section{Measurement of intracellular oxidative stress}

The production of intracellular reactive oxygen species was measured using 2,7dichlorofluorescein diacetate (DCFH-DA) as described previously (16; 17). Cells were seeded at a density of 5000 cells per well in a 96 well plate and after overnight attaching, medium was removed and cells were washed with HBSS. Cells were then incubated with $0.5 \mathrm{mM} \mathrm{CML}$ in the presence of $10 \mu \mathrm{M}$ DCFH-DA. After 24 hours, cells were washed with PBS to remove any DCFH-DA that was not taken up by the cells. Fluorescence (excitation $485 \mathrm{~nm}$; emission $535 \mathrm{~nm}$ ) was measured with the use of a microplate reader.

\section{Gene expression analysis}

RNA was isolated from Qiazol suspended cells according to the manufacturer's protocol and quantified spectrophotometrically. Reverse transcription reaction was performed using $500 \mathrm{ng}$ of RNA, which was reverse-transcribed into cDNA using iScript $^{\mathrm{TM}}$ cDNA synthesis kit (Biorad, Veenendaal, The Netherlands). Next, real time PCR was performed with a BioRad MyiQ iCycler Single Color RT-PCR detection system using Sensimix ${ }^{\mathrm{TM}}$ Plus SYBR and Fluorescein (Quantace-Bioline, Alphen a/d Rijn, The Netherlands), $5 \mu$ diluted (10x) cDNA, and $0.3 \mu \mathrm{M}$ primers in a total volume of $25 \mu \mathrm{l}$. PCR was conducted as follows: denaturation at $95{ }^{\circ} \mathrm{C}$ for 10 minutes, followed by 40 cycles of $95{ }^{\circ} \mathrm{C}$ for 15 seconds and $60{ }^{\circ} \mathrm{C}$ for 45 seconds. After PCR, a melt curve $\left(60-95{ }^{\circ} \mathrm{C}\right)$ was produced for product identification and purity. $\beta$-actin was included as internal control. Primer sequences are shown in table 1. Data were analyzed using the MylQ software system (BioRad) and were expressed as relative gene expression (fold change) using the $2^{\Delta \Delta C t}$ method.

Table 1: Sequences of the primers used in gene expression analysis

\begin{tabular}{|c|c|c|}
\hline Gene & Forward (5' to $\left.3^{\prime}\right)$ & Reverse (5' to $\left.3^{\prime}\right)$ \\
\hline Beta-actin ( $\beta$-actin) & CCTGGCACCCAGCACAAT & GCCGATCCACACGGAGTACT \\
\hline Receptor for AGE (RAGE) & GGCCAGGGCTAGAGTTCC & GCTGTCAGCATCAGCATCAT \\
\hline $\begin{array}{l}\text { Gamma-glutamylcystein } \\
\text { synthetase ( } \nu \text {-GCS) (catalytic } \\
\text { subunit) }\end{array}$ & GCACATCTACCACGCCGTC & CCACCTCATCGCCCCAC \\
\hline Glutathione reductase & CAAGCTGGGTGGCACTTG & TTGGAAAGCCATAATCAGCA \\
\hline $\begin{array}{l}\text { Glutathione S-transferase pi } \\
\text { (GSTP1) }\end{array}$ & GCTCTATGGGAAGGACCAG & CTCAAAAGGCTTCAGTTGC \\
\hline Glutaredoxin-2 & CCGTCGCTAAATTCTCCAAA & TGGCACTCGCTGGAATC \\
\hline
\end{tabular}




\section{Cytokine release}

$1.1 \mathrm{E} 7$ cells were incubated with $0.5 \mathrm{mM} \mathrm{CML}$ for 24 hours. After incubation, culture medium was collected. Cytokines released in the supernatant of the cells were measured using the Bio-plex pro assay according to manufacturer's instructions. This assay uses antibodies coupled to magnetic beads which react with $50 \mu \mathrm{l}$ supernatant. After a series of washes to remove unbound protein, acytokinespecific biotinylated detection antibody was added to the reaction. After 30 minutes incubation and several washes, a streptavidin-phycoerythrin (streptavidin$\mathrm{PE}$ ) reporter complex was added to bind biotinylated detection antibodies. The plate was then read using the Luminex system and data was analyzed using the BioPlex Manager software ${ }^{\mathrm{TM}}$.

\section{GSH/GSSG levels}

$1.1 \mathrm{E} 7$ cells were incubated with $0.5 \mathrm{mM} \mathrm{CML}$ for 24 hours. After incubation, cells were washed with PBS, harvested with trypsin-EDTA and centrifuged (1000xg, 5 minutes, $4{ }^{\circ} \mathrm{C}$ ). Next, cells were washed with ice-cold PBS and centrifuged again. Cell pellets were then resuspended in ice-cold extraction buffer $(0.1 \%$ Triton X-100 and $1.3 \%$ SSA in a $0.1 \mathrm{M}$ potassium phosphate buffer with $5 \mathrm{mM}$ EDTA, $\mathrm{pH} 7.5$ ) and sonicated in icy water for 10 minutes. The extracts were used for determination of intracellular GSH and GSSG content using an enzymatic recycle method described by Rahman et al. (18).

\section{Glutathione reductase activity}

$1.1 \mathrm{E} 7$ cells were incubated with $0.5 \mathrm{mM} \mathrm{CML}$ for 24 hours. After incubation, cells were washed with HBSS, harvested with trypsin-EDTA and centrifuged (1000xg, 5 minutes, $4{ }^{\circ} \mathrm{C}$ ). Cell pellets were then resuspended in $145 \mathrm{mM}$ sodium phosphate buffer $\mathrm{pH} 7.4$ containing $1 \mathrm{mM}$ EDTA. Next, cells were sonicated in icy water for 10 minutes and centrifuged (15 minutes, $10.000 \mathrm{xg}, 4$ 으). Final reaction mixture $(1 \mathrm{ml})$ contained $0.06 \mathrm{mM} \mathrm{NADPH}$ (in $1 \% \mathrm{Na}_{2} \mathrm{CO}_{3}$ ) and $50 \mu \mathrm{l}$ sample in buffer. The reaction was started by the addition of $0.225 \mathrm{mM} \mathrm{GSSG}$ (in $0.01 \mathrm{M} \mathrm{NaOH}$ ). The consumption of NADPH was followed by the decrease in absorbance at $340 \mathrm{~nm}$ for 3 minutes at $37{ }^{\circ} \mathrm{C}$. Activity was corrected for protein content of the samples and expressed in $\mathrm{nmol} / \mathrm{mg}$ protein per minute.

\section{Glutathione transferase activity}

$1.1 \mathrm{E} 7$ cells were incubated with $0.5 \mathrm{mM} \mathrm{CML}$ for 24 hours. After incubation, cells were washed with HBSS, harvested with trypsin-EDTA and centrifuged (1000xg, 5 minutes, $4{ }^{\circ} \mathrm{C}$ ). Cell pellets were then resuspended in $100 \mathrm{mM}$ potassium phosphate buffer pH 6.5 containing 6.3 mM EDTA. Next, cells were sonicated in icy 
water for 10 minutes and centrifuged (15 minutes, $10.000 \mathrm{xg}, 4 \stackrel{\circ}{ } \mathrm{C}$ ). Final reaction mixture $(1 \mathrm{ml})$ contained $1 \mathrm{mM} \mathrm{GSH}$ and $50 \mu \mathrm{l}$ sample in buffer. The reaction was started by the addition of $1 \mathrm{mM} \mathrm{CDNB}$ (in ethanol). The production of GS

dinitrobenzene was followed by the increase in absorbance at $340 \mathrm{~nm}$ for 3 minutes at $37{ }^{\circ} \mathrm{C}$. With each run a spontaneous reaction was included that contained buffer instead of a sample. Activity was corrected for spontaneous reaction and for protein content of the samples and expressed in $\mu \mathrm{mol} / \mathrm{mg}$ protein per minute.

\section{Glutaredoxin activity}

1.1E7 cells were incubated with $0.5 \mathrm{mM} \mathrm{CML}$ for 24 hours. After incubation, cells were washed with HBSS, harvested with trypsin-EDTA and centrifuged (1000xg, 5 minutes, $4{ }^{\circ} \mathrm{C}$ ). Cell pellets were then resuspended in $100 \mathrm{mM}$ potassium phosphate buffer pH 7.0 containing $1 \mathrm{mM}$ EDTA. Next, cells were sonicated in icy water for 10 minutes and centrifuged ( 15 minutes, $10.000 \mathrm{xg}, 4 \stackrel{\circ}{ }$ ). Final reaction mixture $(1 \mathrm{ml})$ contained $0.5 \mathrm{mM} \mathrm{GSH}, 0.2 \mathrm{mM} \mathrm{NADPH}, 1$ unit glutathione reductase and $50 \mu \mathrm{l}$ sample in buffer. The reaction was started by the addition of $0.35 \mathrm{mM}$ 2-hydroxyethyl disulfide (HED). The decrease in absorbance at $340 \mathrm{~nm}$, which accompanies the oxidation of $\mathrm{NADPH}$, was monitored for 3 minutes at $37^{\circ} \mathrm{C}$. Activity was corrected for protein content of the samples and expressed in $\mu \mathrm{mol} / \mathrm{mg}$ protein per minute.

\section{Protein determination}

Protein concentrations were determined spectrophotometrically using the DC protein assay kit (Biorad, Veenendaal, The Netherlands) according to manufacturer's protocol.

\section{Statistical analysis}

The effect of CML incubation was tested using Student's t-test for independent samples or the Mann-Whitney $U$ test when not normally distributed. P-values $<0.05$ were considered statistically significant and $\mathrm{P}$-values $<0.1$ were considered statistical trends. We also include statistical trends because for bioactive molecules like GSH, even a small percentage change in the amount can be of biological relevance. Statistical analyses were analyzed with SPSS for Windows (version 20.0; SPSS Inc., Chicago, IL, USA). 


\section{Results}

\section{CML exposure causes a decrease in viability in beta cells}

The effect of CML exposure on $1.1 \mathrm{E} 7$ cell viability was determined by MTT assay (figure 1A). At concentrations up to $0.125 \mathrm{mM}$ a dose-dependent decrease in viability of $100 \%$ to $87 \%$ was observed, albeit with a high degree of variation between the different experiments. Above $0.125 \mathrm{mM}$ the additional decrease in viability was only $4 \%$. CML concentrations higher than $0.25 \mathrm{mM}$ show a lower degree of variation between the experiments and concentrations higher than 0.5 $\mathrm{mM}$ did not show an additional decrease in viability, therefore a CML concentration of $0.5 \mathrm{mM}$ was chosen as the exposure condition.

\section{CML exposure causes an increase in intracellular oxidative stress}

To determine intracellular levels of reactive oxygen species we used the fluorogenic dye DCFH-DA. After diffusion into the cell, DCFH-DA is enzymatically hydrolyzed by esterases to the non-fluorescent compound DCFH. When ROS are present, DCFH can be oxidized to the highly fluorescent compound DCF. After 24 hour exposure to $\mathrm{CML}$ we found a $23 \%$ increase in DCF fluorescence (figure $1 \mathrm{~B}$ ). This indicates that $\mathrm{CML}$ causes a significant increase in intracellular oxidative stress in the beta cell.
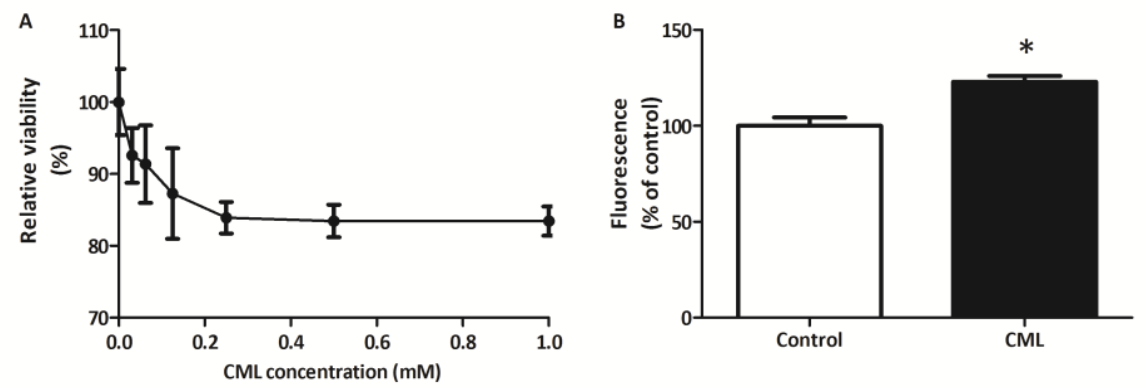

Figure 1: The effect of exposure to different concentrations $\mathrm{N}^{\varepsilon}$-carboxymethyllysine $(\mathrm{CML})$ $(0-2 \mathrm{mM})$ for 24 hours on cell viability of human beta cells (A). Incubation with $0.5 \mathrm{mM} \mathrm{CML}$ for 24 hours increases intracellular oxidative stress (B). Data are expressed as mean \pm standard error of the mean (SEM) of three (MTT) or four (DCFH) independent experiments. * $=p<0.05$ compared to non-exposed cells.

\section{CML exposure increases the levels of MCP-1 in the culture medium}

Because AGEs bind to RAGE, we measured the gene expression of this receptor in the beta cells. We did not observe an effect on gene expression after exposure to CML (figure 2A). Since RAGE activation is associated with an increase in proinflammatory genes, the levels of IL-8 and MCP-1, cytokines which are known to be 
upregulated by RAGE were investigated in the supernatant of cells exposed to CML (19-21). No effects on the levels of IL-8 were observed (figure 2B). MCP-1 levels were increased by almost $40 \%$ (figure $2 \mathrm{C}$ ). Other RAGE associated cytokines were also measured with the Luminex system, but these data are not included because the concentrations were below detection limit.
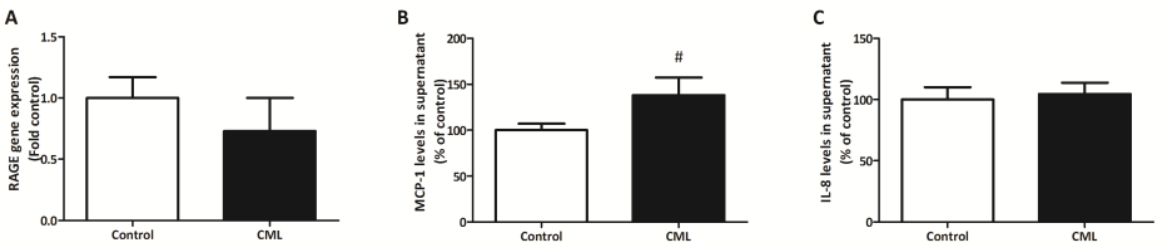

Figure 2: The effect of exposure to $0.5 \mathrm{mM} \mathrm{CML}$ for 24 hours on gene expression of RAGE (A) and the levels of two cytokines which are elevated by RAGE signaling, IL-8 (B) and MCP-1 (C). Data are expressed as mean \pm standard error of the mean (SEM) of three (RAGE expression) or four (IL-8 and MCP-1) independent experiments. \# = p $<0.1$ compared to non-exposed cells.

\section{Effect on components of the glutathione system}

We determined the activity and gene expression of several components of the glutathione system. We observed a trend to a lower GSH concentration of the cells after CML exposure (figure 3A). The GSSG concentration did not change, but was very low and below the detection limit in some samples (figure $3 \mathrm{~B}$ ). The expression of the enzyme gamma-glutamylcystein synthetase ( $\gamma$-GCS), involved in the biosynthesis of GSH, was not affected by exposure to CML (figure $3 \mathrm{C}$ ).
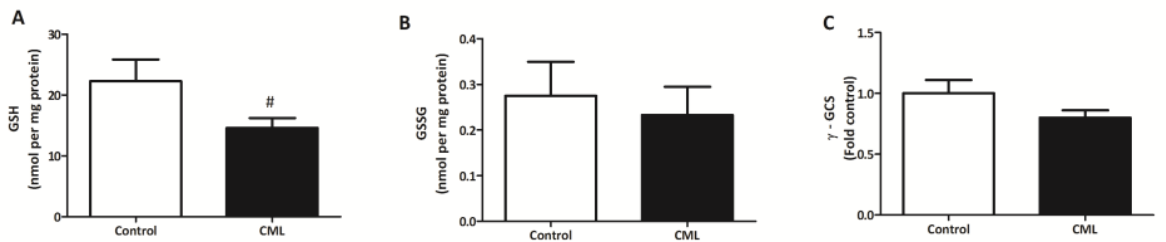

Figure 3: The effect of exposure to $0.5 \mathrm{mM} \mathrm{CML}$ for 24 hours on GSH content (A), GSSG content (B) and gene expression of gamma-glutamylcystein synthetase ( $\gamma-G C S)$ (C). Data are expressed as mean \pm standard error of the mean (SEM) of three independent experiments. \# $=p<0.1$ compared to non-exposed cells.

A trend toward decreased activity of GR after CML exposure was detected, which was not accompanied by a change in gene expression of this enzyme (figure $4 \mathrm{~A}$ and 4B). We also measured GST activity, which did not show any change after CML exposure (figure 4C). Because GST are a large family of genes, the expression of one 


\section{Chapter 4}

specific class was determined. Glutathione S-transferase pi (GSTP1) was chosen because its overexpression has been linked to the prevention of oxidative stress $(22 ; 23)$. We found an upregulation in the expression of GSTP1 when cells were exposed to CML for 24 hours (figure 4D). We did not find any significant changes in glutaredoxin activity or gene expression (figure $4 \mathrm{E}$ and $4 \mathrm{~F}$ ).
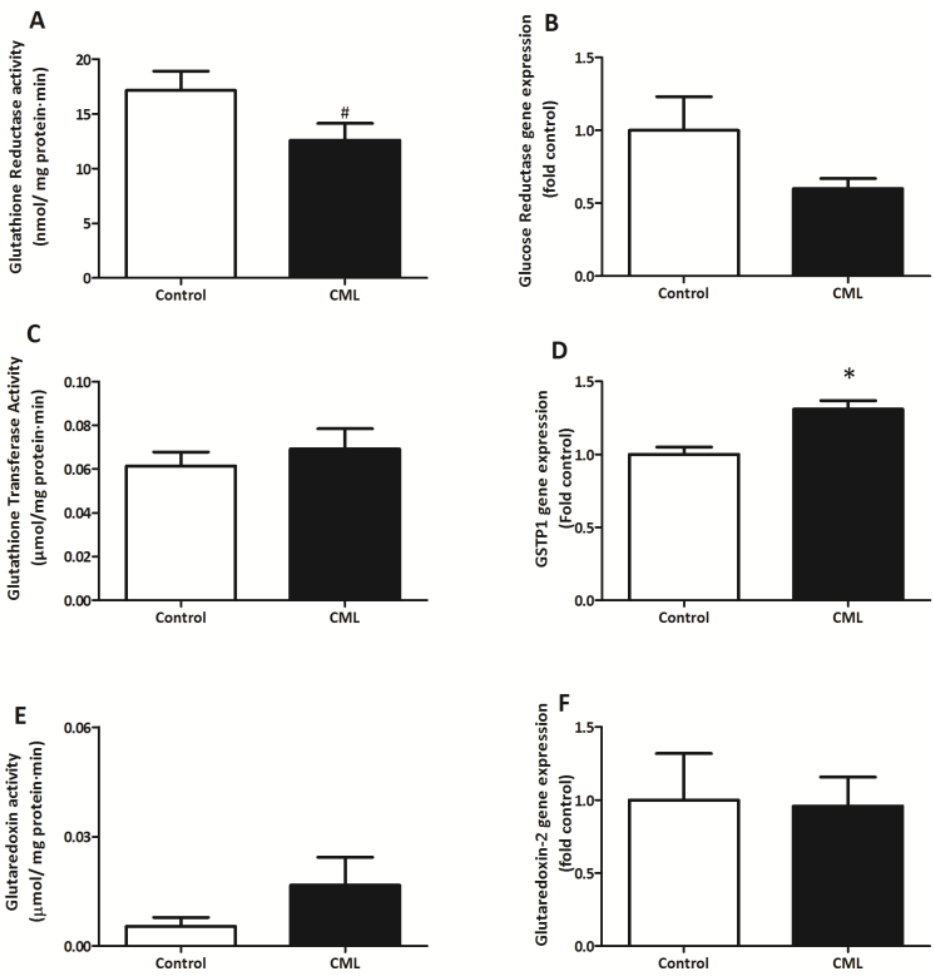

Figure 4: The effect of exposure to $0.5 \mathrm{mM} \mathrm{CML}$ for 24 hours on activity $(A)$ and gene expression (B) of glutathione reductase; activity of glutathione transferase (C) expression of GSTP1 (D); activity of glutaredoxin (E) and expression of glutaredoxin-2 (F). Data are expressed as mean \pm standard error of the mean (SEM) of three (gene expression, GR activity) or four (GST and Grx activity) independent experiments. ${ }^{*}=p<0.05$ compared to non-exposed cells; \# = $p<0.1$ compared to non-exposed cells.

\section{Discussion}

AGE formation is one of the major pathways by which hyperglycemia can cause diabetic complications, therefore AGEs contribute to the pathogenesis of diabetes (24). Beta cell dysfunction and death is involved in the progression of diabetes. 
(25). In this study we investigated the effect of exposure with the AGE CML on a human pancreatic beta cell line.

In this study we used a concentration of $0.5 \mathrm{mM} \mathrm{CML}$ to induce changes in glutathione components. This concentration is higher than usually found in the plasma of diabetic patients, typically reported in the nanomolar or low micromolar range (26-28). This high concentration was chosen to determine the effects of CML in a relatively short incubation time of 24 hours. Since we also use FCS in this model, it is possible that CML binds to FCS and that the actual amount of free CML reacting with the cells is much lower than $0.5 \mathrm{mM}$ and might even be in the in vivo range.

Only a limited number of studies about the effect of AGE on beta cell viability and function have been published. A study in a mouse beta cell line found that exposure to AGEs increased superoxide production in the mitochondria, which led to an impairment of insulin secretion (29). Increased oxidative stress via the mitochondria due to exposure to AGEs was also found in rat beta cells (30). Exposure of different rodent beta cell lines to AGEs induced both proliferation and apoptosis in these cells (31). In line with these studies, we also observed a decrease in beta cell viability after exposure to the AGE CML. This decreased viability was accompanied by an increase in oxidative stress which probably results from the interaction of CML with RAGE.

RAGE is a multiligand transmembrane receptor which belongs to the immunoglobulin gene superfamily (32). Activation of RAGE by AGEs transduces multiple signals resulting in activation and translocation of nuclear transcription factors like NF-KB (4). This leads to the expression of proinflammatory cytokines, including IL-8 and MCP-1 (19-21). It has been shown that CML adducts are signaltransducing ligands for RAGE, both in vitro and in vivo (33). However, another study found that CML-modified proteins were unable to bind to RAGE and activate proinflammatory signaling (34). No changes in the gene expression of RAGE after exposure to $\mathrm{CML}$ were found, but this may be due to the relatively short incubation time of 24 hours. However, increased concentrations of the proinflammatory cytokine MCP-1 were detected, which could be caused by RAGE signaling, as MCP-1 is known to be regulated by RAGE. MCP-1 is involved in the pathogenesis of diabetic nephropathy (35) and is also implicated in the destruction of beta cells in type 1 diabetes (36). The rise in MCP-1 levels could explain the observed increase in intracellular oxidative stress in these cells since MCP-1 has been associated with the induction of oxidative stress in previous studies. MCP-1 enhanced ROS 
generation in monocytes from unstable angina patients (37). Additionally, MCP-1deficiency impaired ROS generation and attenuated oxidative stress in an ovariectomy rodent model (as a model for menopause) (38).

Previous research has shown that AGEs can increase GSSG levels in human neuroblastoma cells (39). Also in vivo an association between AGEs and a decreased glutathione redox ratio in patients undergoing continuous ambulatory peritoneal dialysis was found (40). We found a trend toward a decrease in GSH content in beta cells exposed to CML. The amount of GSSG was already very low and no further change could be detected after CML exposure. A decrease in GSH content has been associated with diabetes in previous studies, e.g. levels of GSH were lower in erythrocytes of type 2 diabetes patients (41). This decrease was associated with a lower activity of the enzyme $y$-GCS which is involved in the biosynthesis of GSH (41). We did not find a change in gene expression of $\gamma$-GCS after exposing the cells to CML. Replenishment of the GSH pool by GR is dependent on the GSSG pool and the availability of NADPH. Since we do not see changes in the GSSG concentration, the amount of available NADPH limits the glutathione reductase activity after $\mathrm{CML}$ exposure.

CML increased the expression of GST in both cell culture and animal models (42). However, they also found increased GSH concentrations with a higher expression of GST. This seemed to be associated with activation of the transcription factor AP1 by RAGE, which in turn might be involved in the induction of GST and $y$-GCS (42). We did find an increase in GSTP1 expression, however we did not find an increase in expression of RAGE and $y$-GCS, which could explain why we did not find an increase in GSH. It is known that expression of Grx is high in beta cells and that Grx might play a regulatory role in insulin exocytosis (43). Glutaredoxin-1 expression has been linked to diabetic retinopathy, by inducing NF-KB translocation and expression of intercellular adhesion molecule-1 (ICAM-1) in rat retinal Müller cells (44). A recent study in patients with abnormal glucose levels found a higher Grx activity in plasma and serum of these patients compared to healthy subjects (45). We did not find any significant changes after 24 hour exposure to CML in activity levels of Grx or expression of glutaredoxin-2.

In conclusion, we found that CML was able to induce cell death in human pancreatic beta cells, which was accompanied by an increase in intracellular oxidative stress. We did not find changes in the expression of RAGE, but we found an increase in the level of a target cytokine of RAGE after CML exposure. Additionally we found that $\mathrm{CML}$ exposure lowered the levels of GSH. Also other 
components of the glutathione system were affected, we found a decrease in glutathione reductase activity and an increase in the expression of GSTP1 (figure 5). These changes in GSH levels and activities of components of the glutathione system indicate that the cells are even more vulnerable for oxidative stress after exposure to CML. Since beta cells are low in antioxidant enzymes and repair for oxidized DNA, it might be that AGEs like CML can accelerate beta cell dysfunction and beta cell death during hyperglycemia.

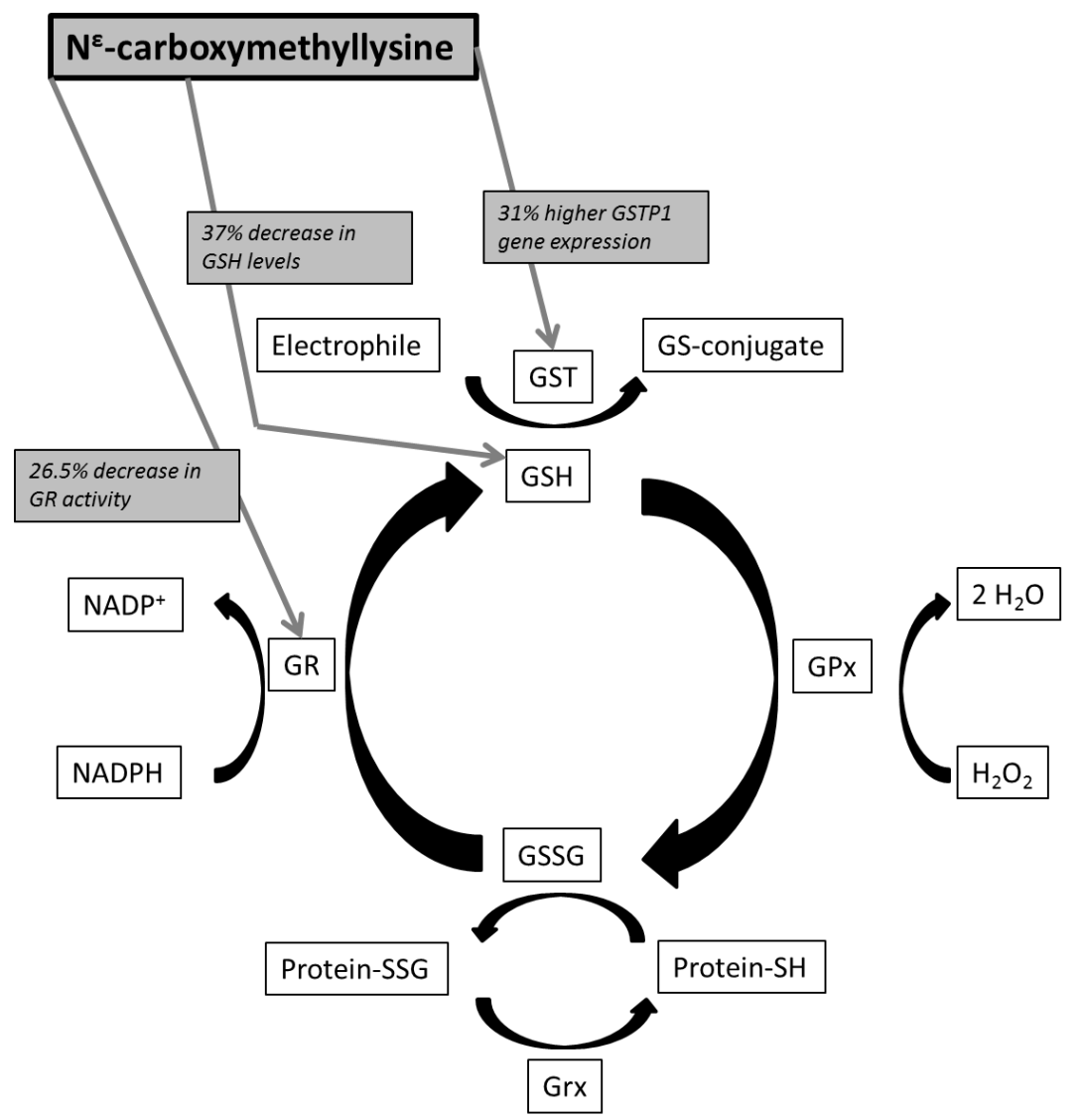

Figure 5: Overview of the glutathione system and the effects of 24 hour incubation with 0.5 $\mathrm{mM} \mathrm{N}^{\varepsilon}$-carboxymethyllysine $(\mathrm{CML})$ on this system in pancreatic beta cells. $\mathrm{GSH}=$ glutathione (reduced form); GSSG = glutathione (oxidized form); GR = glutathione reductase; GPx = glutathione peroxidase; GST = glutathione-S-transferase; NADP = nicotinamide adenine dinucleotide phosphate (oxidized form); $\mathrm{NADPH}=$ nicotinamide adenine dinucleotide phosphate (reduced form); $\mathrm{H}_{2} \mathrm{O}_{2}=$ hydrogen peroxide; $\mathrm{H}_{2} \mathrm{O}=$ water; SSG = glutathione adduct to protein; $\mathrm{SH}=$ thiol group; $\mathrm{Grx}=$ glutaredoxin . 


\section{References}

1. West IC: Radicals and oxidative stress in diabetes. Diabetic Medicine 2000;17:171-180

2. Semba RD, Nicklett EJ, Ferrucci L: Does Accumulation of Advanced Glycation End Products Contribute to the Aging Phenotype? The Journals of Gerontology Series A: Biological Sciences and Medical Sciences 2010;65A:963-975

3. Brownlee M: Biochemistry and molecular cell biology of diabetic complications. Nature 2001;414:813-820

4. Goldin A, Beckman JA, Schmidt AM, Creager MA: Advanced Glycation End Products: Sparking the Development of Diabetic Vascular Injury. Circulation 2006;114:597-605

5. Semba RD, Najjar SS, Sun K, Lakatta EG, Ferrucci L: Serum Carboxymethyl-Lysine, an Advanced Glycation End Product, Is Associated With Increased Aortic Pulse Wave Velocity in Adults. American Journal of Hypertension 2009;22:74-79

6. Semba RD, Ferrucci L, Sun K, Beck J, Dalal M, Varadhan R, Walston J, Guralnik JM, Fried LP: Advanced glycation end products and their circulating receptors predict cardiovascular disease mortality in older community-dwelling women. Aging Clin Exp Res 2009;21:182-190

7. Semba RD, Bandinelli S, Sun K, Guralnik JM, Ferrucci L: Plasma carboxymethyl-lysine, an advanced glycation end product, and all-cause and cardiovascular disease mortality in older community-dwelling adults. J Am Geriatr Soc 2009;57:1874-1880

8. Lenzen S, Drinkgern J, Tiedge M: Low antioxidant enzyme gene expression in pancreatic islets compared with various other mouse tissues. Free Radic Biol Med 1996;20:463-466

9. Tiedge $M$, Lortz S, Drinkgern J, Lenzen S: Relation between antioxidant enzyme gene expression and antioxidative defense status of insulin-producing cells. Diabetes 1997;46:1733-1742

10. Modak MA, Parab PB, Ghaskadbi SS: Pancreatic islets are very poor in rectifying oxidative DNA damage. Pancreas 2009;38:23-29

11. Townsend DM, Tew KD, Tapiero H: The importance of glutathione in human disease. Biomedicine \& Pharmacotherapy 2003;57:145-155

12. Hayes JD, McLellan LI: Glutathione and glutathione-dependent enzymes represent a coordinately regulated defence against oxidative stress. Free Radic Res 1999;31:273-300

13. Pompella A, Visvikis A, Paolicchi A, Tata VD, Casini AF: The changing faces of glutathione, a cellular protagonist. Biochemical Pharmacology 2003;66:1499-1503

14. Fernandes AP, Holmgren A: Glutaredoxins: glutathione-dependent redox enzymes with functions far beyond a simple thioredoxin backup system. Antioxid Redox Signal 2004;6:6374

15. McCluskey JT, Hamid M, Guo-Parke H, McClenaghan NH, Gomis R, Flatt PR: Development and functional characterization of insulin-releasing human pancreatic beta cell lines produced by electrofusion. J Biol Chem 2011;286:21982-21992

16. van de Wier B, Balk JM, Haenen GRMM, Giamouridis D, Bakker JA, Bast BC, den Hartog GJM, Koek GH, Bast A: Elevated citrate levels in non-alcoholic fatty liver disease: The potential of citrate to promote radical production. FEBS Letters 2013;587:2461-2466

17. Ruijters EJB, Weseler AR, Kicken C, Haenen GRMM, Bast A: The flavanol (-)-epicatechin and its metabolites protect against oxidative stress in primary endothelial cells via a direct antioxidant effect. European Journal of Pharmacology 2013;715:147-153

18. Rahman I, Kode A, Biswas SK: Assay for quantitative determination of glutathione and glutathione disulfide levels using enzymatic recycling method. Nat Protoc 2006;1:3159-3165 19. Gu L, Hagiwara S, Fan Q, Tanimoto M, Kobata M, Yamashita M, Nishitani T, Gohda T, Ni Z, Qian J, Horikoshi S, Tomino Y: Role of receptor for advanced glycation end-products and signalling events in advanced glycation end-product-induced monocyte chemoattractant 
protein-1 expression in differentiated mouse podocytes. Nephrol Dial Transplant 2006;21:299-313

20. Nakamura K, Yamagishi S, Adachi H, Kurita-Nakamura Y, Matsui T, Yoshida T, Imaizumi T: Serum levels of sRAGE, the soluble form of receptor for advanced glycation end products, are associated with inflammatory markers in patients with type 2 diabetes. Mol Med 2007;13:185-189

21. Mahali S, Raviprakash N, Raghavendra PB, Manna SK: Advanced glycation end products (AGEs) induce apoptosis via a novel pathway: involvement of $\mathrm{Ca} 2+$ mediated by interleukin-8 protein. J Biol Chem 2011;286:34903-34913

22. Goto S, Kawakatsu M, Izumi S-i, Urata Y, Kageyama K, Ihara Y, Koji T, Kondo T: Glutathione S-transferase $\pi$ localizes in mitochondria and protects against oxidative stress. Free Radical Biology and Medicine 2009;46:1392-1403

23. Huang J, Tan PH, Tan BK, Bay BH: GST-pi expression correlates with oxidative stress and apoptosis in breast cancer. Oncol Rep 2004;12:921-925

24. Brownlee M: The Pathobiology of Diabetic Complications: A Unifying Mechanism. Diabetes 2005;54:1615-1625

25. Ashcroft Frances $M$, Rorsman P: Diabetes Mellitus and the $\beta$ Cell: The Last Ten Years. Cell 2012;148:1160-1171

26. Hanssen NMJ, Engelen L, Ferreira I, Scheijen JLJM, Huijberts MS, van Greevenbroek MMJ, van der Kallen CJH, Dekker JM, Nijpels G, Stehouwer CDA, Schalkwijk CG: Plasma Levels of Advanced Glycation Endproducts $\mathrm{N} \epsilon$-(carboxymethyl)lysine, $\mathrm{N} \epsilon$-(carboxyethyl)lysine, and Pentosidine Are not Independently Associated With Cardiovascular Disease in Individuals With or Without Type 2 Diabetes: The Hoorn and CODAM Studies. The Journal of Clinical Endocrinology \& Metabolism 2013;98:E1369-E1373

27. Nin JW, Jorsal A, Ferreira I, Schalkwijk CG, Prins MH, Parving H-H, Tarnow L, Rossing P, Stehouwer CD: Higher Plasma Levels of Advanced Glycation End Products Are Associated With Incident Cardiovascular Disease and All-Cause Mortality in Type 1 Diabetes: A 12-year follow-up study. Diabetes Care 2011;34:442-447

28. Lieuw-A-Fa MLM, van Hinsbergh VWM, Teerlink T, Barto R, Twisk J, Stehouwer CDA, Schalkwijk CG: Increased levels of $\mathrm{N} \epsilon$-(carboxymethyl)lysine and $\mathrm{N} \epsilon$-(carboxyethyl)lysine in type 1 diabetic patients with impaired renal function: correlation with markers of endothelial dysfunction. Nephrology Dialysis Transplantation 2004;19:631-636

29. Coughlan MT, Yap FY, Tong DC, Andrikopoulos S, Gasser A, Thallas-Bonke V, Webster DE, Miyazaki J, Kay TW, Slattery RM, Kaye DM, Drew BG, Kingwell BA, Fourlanos S, Groop PH, Harrison LC, Knip M, Forbes JM: Advanced glycation end products are direct modulators of beta-cell function. Diabetes 2011;60:2523-2532

30. Lin N, Zhang H, Su Q: Advanced glycation end-products induce injury to pancreatic beta cells through oxidative stress. Diabetes Metab 2012;38:250-257

31. Lim M, Park L, Shin G, Hong H, Kang I, Park Y: Induction of Apoptosis of $\beta$ Cells of the Pancreas by Advanced Glycation End-Products, Important Mediators of Chronic Complications of Diabetes Mellitus. Annals of the New York Academy of Sciences 2008;1150:311-315

32. Neeper M, Schmidt AM, Brett J, Yan SD, Wang F, Pan YC, Elliston K, Stern D, Shaw A: Cloning and expression of a cell surface receptor for advanced glycosylation end products of proteins. J Biol Chem 1992;267:14998-15004

33. Kislinger T, Fu C, Huber B, Qu W, Taguchi A, Du Yan S, Hofmann M, Yan SF, Pischetsrieder $M$, Stern D, Schmidt AM: $N \varepsilon$-(Carboxymethyl)Lysine Adducts of Proteins Are Ligands for Receptor for Advanced Glycation End Products That Activate Cell Signaling Pathways and Modulate Gene Expression. Journal of Biological Chemistry 1999;274:31740-31749 
34. Buetler TM, Leclerc E, Baumeyer A, Latado H, Newell J, Adolfsson O, Parisod V, Richoz J, Maurer S, Foata F, Piguet D, Junod S, Heizmann CW, Delatour T: NE-carboxymethyllysinemodified proteins are unable to bind to RAGE and activate an inflammatory response. Molecular Nutrition \& Food Research 2008;52:370-378

35. Wada T, Yokoyama H, Matsushima K, Kobayashi Ki: Monocyte chemoattractant protein1: does it play a role in diabetic nephropathy? Nephrology Dialysis Transplantation 2003;18:457-459

36. Kutlu B, Darville MI, Cardozo AK, Eizirik DL: Molecular Regulation of Monocyte Chemoattractant Protein-1 Expression in Pancreatic $\beta$-Cells. Diabetes 2003;52:348-355

37. Aukrust $P$, Berge RK, Ueland T, Aaser E, Damås JK, Wikeby L, Brunsvig A, Müller F, Forfang $\mathrm{K}$, Frøland SS, Gullestad L: Interaction between chemokines and oxidative stress: possible pathogenic role in acute coronary syndromes. Journal of the American College of Cardiology 2001;37:485-491

38. Kim W-K, Choi E-K, Sul O-J, Park Y-K, Kim E-S, Yu R, Suh J-H, Choi H-S: Monocyte Chemoattractant Protein-1 Deficiency Attenuates Oxidative Stress and Protects against Ovariectomy-Induced Chronic Inflammation in Mice. PLoS One 2013;8:e72108

39. Deuther-Conrad W, Loske C, Schinzel R, Dringen R, Riederer P, Münch G: Advanced glycation endproducts change glutathione redox status in SH-SY5Y human neuroblastoma cells by a hydrogen peroxide dependent mechanism. Neuroscience Letters 2001;312:29-32

40. Şahin E, Göçmen AY, Koçak H, Tuncer $M$, Gümüşlü $S$ : The association of advanced glycation end-products with glutathione status. Annals of Clinical Biochemistry 2008;45:369374

41. Murakami K, Kondo T, Ohtsuka Y, Fujiwara Y, Shimada M, Kawakami Y: Impairment of glutathione metabolism in erythrocytes from patients with diabetes mellitus. Metabolism 1989;38:753-758

42. Faist V, Hofmann T, Zill H, Baynes JW, Thorpe SR, Sebekova K, Schinzel R, Heidland A, Wenzel E, Erbersdobler HF: Effects of dietary $\mathrm{N} \varepsilon$-carboxymethyllysine on expression of the biotransformation enzyme, glutathione-S-transferase, in the rat. International Congress Series 2002;1245:313-320

43. Ivarsson R, Quintens R, Dejonghe S, Tsukamoto K, in 't Veld P, Renström E, Schuit FC: Redox Control of Exocytosis: Regulatory Role of NADPH, Thioredoxin, and Glutaredoxin. Diabetes 2005;54:2132-2142

44. Shelton MD, Kern TS, Mieyal JJ: Glutaredoxin Regulates Nuclear Factor K-B and Intercellular Adhesion Molecule in Müller Cells: MODEL OF DIABETIC RETINOPATHY. Journal of Biological Chemistry 2007;282:12467-12474

45. Du Y, Zhang H, Montano S, Hegestam J, Ekberg N, Holmgren A, Brismar K, Ungerstedt J: Plasma glutaredoxin activity in healthy subjects and patients with abnormal glucose levels or overt type 2 diabetes. Acta Diabetol 2013:1-8 


\section{Chapter 5}

\section{Health effects of erythritol}

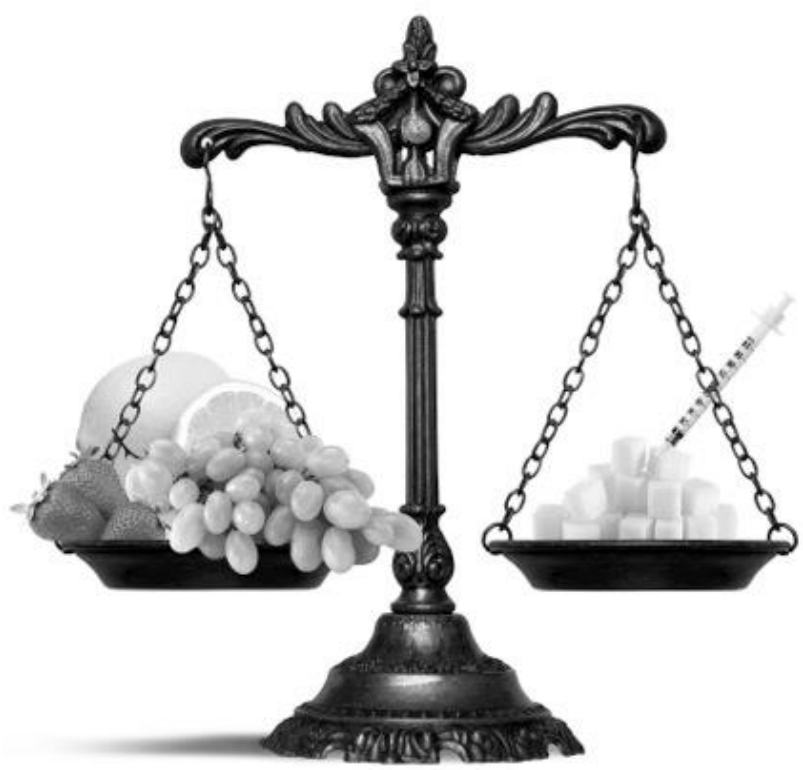

Daniëlle M.P.H.J. Boesten

Gertjan J.M. den Hartog

Peter de Cock

Douwina Bosscher

Angela Bonnema

Aalt Bast 


\section{Chapter 5}

\section{Abstract}

Erythritol (1,2,3,4-butanetetrol) is a non-caloric C4 polyol made by fermentation that has a sweetness of $60-70 \%$ that of sucrose. The safety of erythritol has been consistently demonstrated in animal and human studies. Erythritol has a higher digestive tolerance compared to all other polyols because about $90 \%$ of the ingested erythritol is readily absorbed and excreted unchanged in urine. Erythritol is used in a wide range of applications for sweetening and other functionalities, e,g, in beverages, chewing gum and candies. In this review we summarize the health effects of erythritol described in literature. We focus on studies involving the anticariogenic and the endothelial protective effects of erythritol. We conclude that erythritol can be of great importance and considered to be the preferred sugar replacer for a rapidly growing population of people with diabetes or prediabetes to reduce their risk of developing diabetic complications. 


\section{General characteristics}

Erythritol (1,2,3,4-butanetetrol) is a 4-carbon sugar alcohol or polyol, it has the unique property that it is a meso butanetetrol (figure 1). It occurs naturally in some mushrooms, some fruits (e.g. watermelon, grapes and pears) and in fermented foods including wine, cheese, sake and soy sauce $[1,2]$. Consumption of erythritol from its natural occurrence in foods has been estimated to be $80 \mathrm{mg}$ per day ( 1.3 $\mathrm{mg} / \mathrm{kg}$ body weight per day) in the United States [2]. Erythritol is also found endogenously in human and animal tissues and body fluids including blood, urine and cerebrospinal fluid [2].

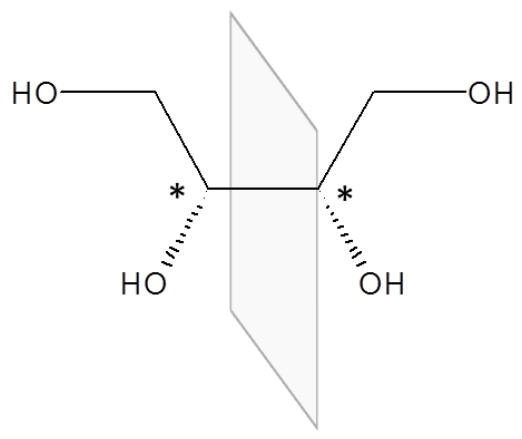
2R,3S-1,2,3,4-butanetetrol erythritol

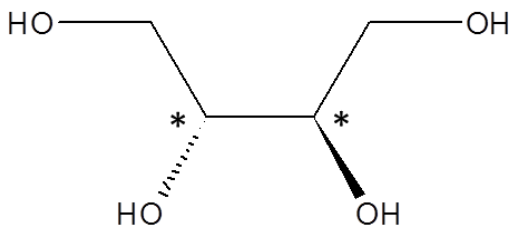

2R,3R-1,2,3,4-butanetetrol
D-threitol

Figure 1: Two possible stereoisomers of 1,2,3,4-butanetetrol are shown. On the left: erythritol, the $2 \mathrm{R}, 3 \mathrm{~S}$ isomer. Although this compound contains 2 asymmetric carbon atoms, the overall molecule is achiral because it contains a intramolecular plane of symmetry. This plane of symmetry is absent in the compound on the right, D-threitol, which is therefore chiral: It has a enantiomer (mirror image) L-threitol (not shown).

Erythritol is a white, anhydrous, non-hydroscopic and crystalline substance. It is 60$70 \%$ as sweet as sucrose [3]. Although erythritol was first isolated in 1852, it took until 1990 for it to be marketed as a new natural sweetener in Japan. Currently, the use of erythritol in foods has been approved in more than 60 countries. The range of applications include table top sweeteners, beverages, chewing gum, chocolate, candies and bakery products [3].

\section{Manufacturing process}

Large scale production of erythritol uses fermentation, a natural process. As a starting material pure glucose, sucrose or glucose from maize (as a source of starch) is used. Starch is extracted from the maize and through hydrolysis the 
starch chains are broken down into glucose molecules which are fermented into erythritol using an osmophilic yeast, like Moniliella pollinis. After fermentation, yeast cells and other impurities are removed by filtering. Once the fermentation broth is filtered, erythritol is purified by ion exchange resin, activated charcoal, and ultrafiltration. In the last step, crystallization, the broth is cooled down and erythritol precipitates from the solution yielding crystals with over $99 \%$ purity $[4,3]$.

\section{Safety}

A number of toxicological studies have been performed to evaluate the safety of erythritol. These have been extensively discussed in reviews by Bernt et al. and Munro et al. [2,5].

In summary, based on acute toxicity studies, erythritol is classified as essentially non-toxic after oral administration. Subchronic studies further support the safety of erythritol. Chronic studies (up to 2 years) revealed no effect on survival or carcinogenicity by erythritol [2,5]. Even at high doses (up to $16 \mathrm{~g} / \mathrm{kg}$ body weight), erythritol does not affect reproductive performance or fertility of parental rats. In addition, no adverse effects on the developing foetus were observed $[6,7,2,5]$. Erythritol does not possess mutagenic potential as observed in the Ames test and chromosomal aberration test $[5,2,8,9]$.

In summary, animal toxicological studies and clinical studies have consistently demonstrated the safety of erythritol. Therefore it is not expected that erythritol will cause adverse effects under the conditions of its intended use in food.

\section{Metabolic fate}

The metabolic profile of erythritol is not like any other polyol which gives rise to some of erythritols' unique properties. Erythritol is readily and virtually completely absorbed from the small intestine via passive diffusion similar to fructose. Fructose transport can also occur via GLUT2 transport with absorption enhanced in the presence of glucose due to greater GLUT2 insertion in the apical membrane as SGLT1 transports glucose. This explains the enhanced absorption of fructose in the presence of glucose. In addition, the presence of glucose has been shown to enhance paracellular flow due to the opening of tight junctions resulting in increased absorption of small solutes [10]. Enhanced GLUT2 insertion and enhanced paracellular flow in the presence of glucose has been hypothesized to be the same pathway with altered functions in the absence/presence of glucose. However, this hypothesis does not support the differences noted for minor increases in small solute transport compared to the greatly enhanced transport of 
fructose when glucose is present $[11,12]$. As erythritol is readily absorbed on its own, the impact of the presence of glucose on erythritol absorption would be minimal and has not been investigated to date. After absorption, erythritol is distributed throughout the body, with maximum plasma concentrations occurring within the first 2 hours of digestion. Up to $90 \%$ is excreted unchanged in the urine. $[13,14,5]$.

Unabsorbed erythritol may be subjected to microbial fermentation in the colon. However, studies with $13 \mathrm{C}$-erythritol showed no increase in breath $13 \mathrm{CO}_{2}$ and $\mathrm{H}_{2}$, which indicated that erythritol was not metabolized by the host [15]. Inability of faecal flora to metabolise erythritol was confirmed in in vitro studies with fermentation times up to 24 hours $[15,16]$. The potential for erythritol fermentation exists with exceedingly high doses, much greater than are represented with current intake [17].

Erythritol has a digestive tolerance that is much higher compared to other polyols. This can mainly be attributed to the fact that it is readily absorbed and only a small fraction reaches the colon. Other polyols are poorly absorbed, which can provoke undesirable intestinal effects when they are consumed in excessive quantities. These effects can occur due to gas formation by fermentation (leading to flatulence) or they are the result of osmotic effects (leading to laxative effects). Gastrointestinal responses of persons ingesting erythritol at up to $0.8 \mathrm{~g} / \mathrm{kg}$ body weight were comparable to those of sucrose [13]. Also repeated ingestion of erythritol at daily doses of $1 \mathrm{~g} / \mathrm{kg}$ body weight did not show more frequent gastrointestinal effects than sucrose, indicating that erythritol was well tolerated [18]. When $35 \mathrm{~g}$ erythritol was consumed in a drink it was well tolerated, while at a dose of $50 \mathrm{~g}$ only significant increases in borborygmi and nausea where observed. The consumption of 35 and $50 \mathrm{~g}$ xylitol in the same study induced significant gastrointestinal distress [19]. The maximum dose of erythritol not causing laxation was calculated to be $0.80 \mathrm{~g} / \mathrm{kg}$ body weight for females and $0.66 \mathrm{~g} / \mathrm{kg}$ for males [20]. However, the maximum dose is also dependent on the delivery method. Consumption of erythritol with solid foods is tolerated at a higher intake level than with beverages, because digestion of food products is slower providing a longer period for absorption to occur [19].

Because of its metabolic profile, erythritol does not provide energy to the body and therefore has a caloric value of 0 calories per gram [3]. In addition, erythritol does not raise plasma glucose or insulin levels and can therefore be regarded as safe for diabetic patients. No effect on plasma glucose or insulin levels was observed within 
3 hours after ingestion of $1 \mathrm{~g} / \mathrm{kg}$ body weight erythritol [14]. Ingestion of $0.3 \mathrm{~g} / \mathrm{kg}$ body weight erythritol did not influence serum glucose or insulin levels, whereas the same dose of glucose rapidly increased these levels [21].

\section{Health effects}

\section{Dental health}

Mutans streptococci play an important role in the development of dental plaque. They attach to the biofilm on teeth and produce glucosyltransferase. This enzyme is responsible for the synthesis of insoluble glucan plaque material. Glucans and the bacteria accumulate on the teeth and are known as dental plaque. When large amounts of plaque form on teeth in presence of sugar, the mutans streptococci produce lactic acid. The acid weakens tooth enamel through demineralization, ultimately causing dental caries [3,22].

When erythritol was incubated with a range of mutans streptococci species no lactic acid production was observed. Furthermore, it was not used for growth or plaque formation by the mutans streptococci [23]. Another study showed that erythritol inhibited the growth of several strains of mutans streptococci strains [24]. A study by Hashino et al. showed that erythritol has inhibitory effects on Porphyromonas gingivalis and Streptococcus gordonii heterotypic biofilm development via several pathways, including a decrease in DNA/RNA synthesis, decreased extracellular matrix production and alterations of dipeptide acquisition and amino acid metabolism [25].

This was also supported by an in vivo study into the effects of 6-month use of erythritol, xylitol and glucose (in the form of chewable tablets and toothpaste). Erythritol and xylitol led to a significant reduction in the amount of plaque and saliva levels of mutans streptococci. In addition, a reduction in the amount of dental plaque was observed in subjects that had received erythritol and xylitol [24]. A 3 year clinical trial also found that erythritol promotes dental health [26]. In this study initially 7-8 year old children were given erythritol, xylitol or sorbitol candies containing $7.5 \mathrm{~g}$ of the polyol daily for three years. Erythritol consistently reduced the amount of dental plaque during the follow up period. In addition, the plaque of erythritol receiving subjects showed a reduction in the levels of acetic acid, propionic acid and lactic acid. Furthermore, erythritol consumption led to a lower salivary and plaque mutans streptococci counts compared with other groups. This longterm study also investigated the impact of polyol consumption on dental caries development [27]. It was found that a lower number of children in the erythritol group developed enamel or dentin caries over the three years ( $4.6 \%$ versus $5.5 \%$ in 
the sorbitol and $5.8 \%$ in the xylitol group). In addition, in the erythritol group a lower number of enamel caries tooth surfaces developed to dentin caries $1.3 \%$ versus $1.7 \%$ in the sorbitol and $2.0 \%$ in the xylitol group). Furthermore, the time to development of enamel/dentin and dentin caries lesions (surfaces) was statistically significantly longer in the erythritol group compared to the sorbitol or xylitol group. These studies demonstrate that erythritol can reduce the risk of dental caries development.

\section{Antioxidant properties}

It is well known that the polyol mannitol is a hydroxyl radical scavenger $[28,29]$. Since erythritol closely resembles the structure of mannitol, den Hartog et al. investigated the hydroxyl radical scavenging capacity of erythritol and several other polyols. A correlation between the number of hydroxyl groups in the investigated compound and its rate constant for the reaction with hydroxyl radicals was found. Erythritol proved to be an excellent hydroxyl radical scavenger with a rate constant of $1.18 \times 109 \mathrm{M}-1 \mathrm{~s}-1[30]$.

In the same study the ability of erythritol to scavenge superoxide radicals was investigated. Erythritol proved to be inert towards superoxide radicals, probably because it lacks a major structural requirement for superoxide scavengers. The ability of erythritol to scavenge radicals in a cellular system was tested with a hemolysis assay. Erythritol delayed radical-induced hemolysis in red blood cells in a concentration dependent manner [30].

The reaction of erythritol with hydroxyl radicals was also demonstrated in an in vivo model using diabetic rats. The rats were fed $1000 \mathrm{mg} / \mathrm{kg}$ per day for a period of 3 weeks after diabetes was induced by streptozotocin. The urine of the rats was investigated for the presence of two oxidative metabolites of erythritol: erythrose and erythrulose. The amount of erythrose in the urine was highest in the diabetic group fed with erythritol, indicating that erythritol scavenged hydroxyl radicals produced during hyperglycemia in these rats [30].

In another in vivo study by Yokozawa et al. antioxidant properties of erythritol were also investigated [31]. Several doses of erythritol (100, 200 and $400 \mathrm{mg} / \mathrm{kg}$ body weight) were orally administrated to streptozotocin induced diabetic rats for 10 days. The highest dose resulted in a decrease of 5-hydroxymethylfurfural (5-HMF) levels, a marker for the extent of glycosylation of serum protein. In addition, thiobarbituric acid reactive substances levels of serum, liver and kidney were lower in the groups that received erythritol, indicating a reduction of lipid peroxidation (a 
marker of oxidative stress). This study also found a reduction in serum, liver and kidney glucose levels and a reduction in serum creatinine when rats were given erythritol. They conclude that erythritol is able to affect glucose metabolism and reduce lipid peroxidation and kidney damage caused by hyperglycemia [31].

\section{Endothelial protective effects}

Most of the complications that arise from chronic hyperglycemia find their origin in damaging the endothelium, a thin layer of cells lining the cardiovascular system [32-34]. The endothelium plays an important role in numerous physiological functions with one of the most important endothelium-derived mediator being the soluble gaseous radical nitric oxide (NO), responsible for vascular relaxation. Endothelial dysfunction occurs when the endothelium loses its physiological properties. This has been linked to diabetes through demonstration of impaired endothelial-dependent vasodilatation [35].

The study of den Hartog et al. also focused on the effect of erythritol on endothelial function. This was investigated in rings prepared from the thoracic aorta. Carbachol concentration response curves were recorded for the different groups (figure 2). In diabetic rats the ex vivo carbachol response is smaller and requires higher concentrations than in control rats. This indicates that the endothelium of these rats is damaged. Since the carbachol response is mediated by NO, the diabetic rats seem to be incapable of generating sufficient $\mathrm{NO}$ to induce maximum relaxation. In diabetic rats fed with erythritol the carbachol response curve was similar to control rats, indicating that the loss of endothelium dependent vascular relaxation was prevented by erythritol in these rats [30].

To further investigate the endothelium protective effect a study in endothelial cells was performed [36]. The cells were exposed to normal and high glucose concentrations and targeted and transcriptomic approaches were used to examine the effect of erythritol under these conditions. Overall, it was found that erythritol by itself (i.e. under non-diabetic conditions) has no effect on the endothelial cells. However, under high glucose conditions, erythritol was able to reverse a number of deleterious effects. The most striking observation was that erythritol reversed the direction of change of 148 of the 153 transcripts altered by high glucose incubation. Another finding was that erythritol did not seem to affect single endpoints, but rather had an effect on multiple targets. A mode of action which is not uncommon for natural compounds [37,38]. 


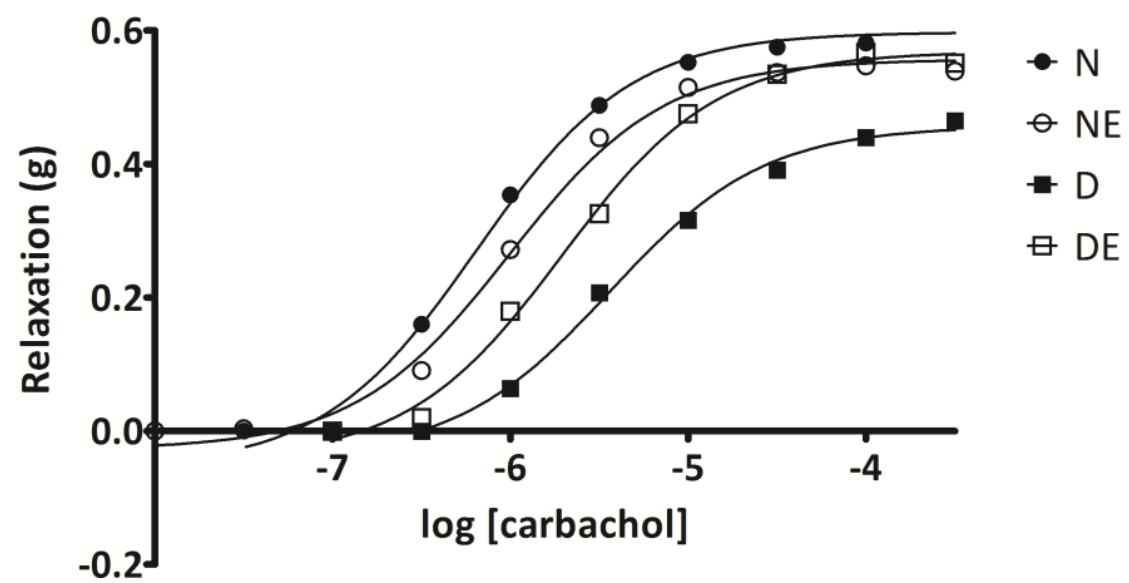

Figure 2: Carbachol concentration-response curves recorded with aortic rings from normoglycemic rats ( $\mathrm{N}$; closed circles). diabetic rats ( $\mathrm{D}$; closed squares) normoglycemic rats that had consumed erythritol (NE; open circles) and diabetic rats that had consumed erythritol (DE; open squares). In diabetic rats the ex vivo carbachol response is smaller and requires higher concentrations than in control rats. Erythritol prevents the loss of response to carbachol, thus maintaining endothelium dependent vascular relaxation. Adapted from den Hartog et al. [30].

A pilot study on the effects of erythritol in patients with type 2 diabetes also revealed protective effects on vascular function [39]. In this study 24 subjects consumed $12 \mathrm{~g}$ of erythritol three times daily for 4 weeks. Subjects were tested at baseline and after 4 weeks. In addition, acute and acute-on-chronic effects before and 2 hours after consumption of $24 \mathrm{~g}$ erythritol at baseline and follow up visit were measured. Acute consumption of erythritol improved small vessel endothelial function as measured by fingertip peripheral arterial tonometry (EndoPAT). Chronic erythritol consumption showed a decrease in central pulse pressure and a trend towards a lower carotid-femoral pulse wave velocity. These findings suggest that erythritol can reduce arterial stiffness and improve small vessel endothelial function. However, this was a pilot study without a control group and a modest sample size. To validate the findings of this study a randomized, placebo-controlled study is required [39].

\section{Conclusion}

Erythritol is a non-caloric bulk sweetener which has been shown in multiple studies to reduce the risk of caries development. As erythritol does not influence glucose or insulin levels it is a good alternative for sugar in patients with diabetes as well as 
for people needing or desiring to manage blood sugar levels due to prediabetes or compromised carbohydrate metabolism. In addition, diabetes patients could benefit from the vascular effects of erythritol described above. It is expected that in non-diabetic subjects the endothelium will not be affected by erythritol. However, in diabetic subjects, where the endothelium is under diabetic stress, erythritol could shift a variety of damage and dysfunction parameters to a safer side as observed in the found in vitro, in vivo (rat) studies and in a clinical study with type 2 diabetes patients. Erythritol can therefore be regarded as a compound that has protective effects on the endothelium under high glucose conditions, leading to a prevention or delay in onset of diabetic complications.

The characteristic of erythritol to have small effects on multiple targets may also prove to be beneficial. A compound with a strong biological effect is less suitable for chronic supplementation as is needed in diabetes. The alternative is to use a compound with mild protective effects like erythritol. Erythritol can therefore be of great importance and considered to be the preferred sugar replacer for a rapidly growing population of people with diabetes or prediabetes to reduce their risk of developing diabetic complications. 


\section{References}

1. Sreenath K, Venkatesh YP (2008) Analysis of erythritol in foods by polyclonal antibody-based indirect competitive ELISA. Anal Bioanal Chem 391 (2):609-615. doi:10.1007/s00216-008-2016-x

2. Bernt WO, Borzelleca JF, Flamm G, Munro IC (1996) Erythritol: a review of biological and toxicological studies. Regul Toxicol Pharmacol 24 (2 Pt 2):S191-197

3. de Cock P (2012) Erythritol. In: Sweeteners and Sugar Alternatives in Food Technology. WileyBlackwell, pp 213-241. doi:10.1002/9781118373941.ch10

4. Moon HJ, Jeya M, Kim IW, Lee JK (2010) Biotechnological production of erythritol and its applications. Appl Microbiol Biotechnol 86 (4):1017-1025. doi:10.1007/s00253-010-2496-4

5. Munro IC, Berndt WO, Borzelleca JF, Flamm G, Lynch BS, Kennepohl E, Bar EA, Modderman J, Bernt WO (1998) Erythritol: an interpretive summary of biochemical, metabolic, toxicological and clinical data. Food and Chemical Toxicology 36 (12):1139-1174

6. Waalkens-Berendsen DH, Smits-van Prooije AE, Wijnands MV, Bar A (1996) Two-generation reproduction study of erythritol in rats. Regul Toxicol Pharmacol 24 (2 Pt 2):S237-246

7. Shimizu M, Katoh M, Imamura M, Modderman J (1996) Teratology study of erythritol in rabbits. Regul Toxicol Pharmacol 24 (2 Pt 2):S247-253. doi:10.1006/rtph.1996.0105

8. Kawamura Y, Saito Y, Imamura M, Modderman JP (1996) Mutagenicity studies on erythritol in bacterial reversion assay systems and in Chinese hamster fibroblast cells. Regul Toxicol Pharmacol 24 (2 Pt 2):S261-263

9. Chung YS, Lee M (2013) Genotoxicity Assessment of Erythritol by Using Short-term Assay. Toxicol Res 29 (4):249-255. doi:10.5487/tr.2013.29.4.249

10. Shi X, Schedl HP, Summers RM, Lambert GP, Chang RT, Xia T, Gisolfi CV (1997) Fructose transport mechanisms in humans. Gastroenterology 113 (4):1171-1179

11. Kellett GL, Brot-Laroche E (2005) Apical GLUT2: a major pathway of intestinal sugar absorption. Diabetes 54 (10):3056-3062

12. Gibson PR, Newnham E, Barrett JS, Shepherd SJ, Muir JG (2007) Review article: fructose malabsorption and the bigger picture. Aliment Pharmacol Ther 25 (4):349-363. doi:10.1111/j.1365-2036.2006.03186.x

13. Bornet FR, Blayo A, Dauchy F, Slama G (1996) Gastrointestinal response and plasma and urine determinations in human subjects given erythritol. Regul Toxicol Pharmacol 24 (2 Pt 2):S296-302. doi:10.1006/rtph.1996.0111

14. Bornet FRJ, Blayo A, Dauchy F, Slama G (1996) Plasma and Urine Kinetics of Erythritol after Oral Ingestion by Healthy Humans. Regulatory Toxicology and Pharmacology 24 (2):S280-S285. doi:http://dx.doi.org/10.1006/rtph.1996.0109

15. Hiele $M$, Ghoos $Y$, Rutgeerts $P$, Vantrappen $G$ (1993) Metabolism of erythritol in humans: comparison with glucose and lactitol. Br J Nutr 69 (1):169-176

16. Arrigoni E, Brouns F, Amado R (2005) Human gut microbiota does not ferment erythritol. British Journal of Nutrition 94 (5):643-646

17. Beards E, Tuohy K, Gibson G (2010) Bacterial, SCFA and gas profiles of a range of food ingredients following in vitro fermentation by human colonic microbiota. Anaerobe 16 (4):420425. doi:10.1016/j.anaerobe.2010.05.006

18. Tetzloff W, Dauchy F, Medimagh S, Carr D, Bar A (1996) Tolerance to subchronic, high-dose ingestion of erythritol in human volunteers. Regul Toxicol Pharmacol 24 (2 Pt 2):S286-295. doi:10.1006/rtph.1996.0110

19. Storey D, Lee A, Bornet F, Brouns F (2007) Gastrointestinal tolerance of erythritol and xylitol ingested in a liquid. Eur J Clin Nutr 61 (3):349-354. doi:10.1038/sj.ejcn.1602532

20. Oku T, Okazaki M (1996) Laxative threshold of sugar alcohol erythritol in human subjects. Nutrition Research 16 (4):577-589. doi:http://dx.doi.org/10.1016/0271-5317(96)00036-X

21. Noda K, Nakayama K, Oku T (1994) Serum glucose and insulin levels and erythritol balance after oral administration of erythritol in healthy subjects. European Journal of Clinical Nutrition 48 (4):286-292

22. Rosan B, Lamont RJ (2000) Dental plaque formation. Microbes and Infection 2 (13):1599-1607. doi:http://dx.doi.org/10.1016/S1286-4579(00)01316-2 
23. Kawanabe J, Hirasawa M, Takeuchi T, Oda T, Ikeda T (1992) Noncariogenicity of erythritol as a substrate. Caries Res 26 (5):358-362

24. Makinen KK, Saag M, Isotupa KP, Olak J, Nommela R, Soderling E, Makinen PL (2005) Similarity of the effects of erythritol and xylitol on some risk factors of dental caries. Caries Res 39 (3):207215. doi:10.1159/000084800

25. Hashino E, Kuboniwa M, Alghamdi SA, Yamaguchi M, Yamamoto R, Cho H, Amano A (2013) Erythritol alters microstructure and metabolomic profiles of biofilm composed of Streptococcus gordonii and Porphyromonas gingivalis. Mol Oral Microbiol 28 (6):435-451. doi:10.1111/omi.12037

26. Runnel R, Mäkinen KK, Honkala S, Olak J, Mäkinen P-L, Nõmmela R, Vahlberg T, Honkala E, Saag M (2013) Effect of three-year consumption of erythritol, xylitol and sorbitol candies on various plaque and salivary caries-related variables. Journal of Dentistry 41 (12):1236-1244. doi:http://dx.doi.org/10.1016/j.jdent.2013.09.007

27. Honkala S, Runnel R, Saag M, Olak J, Nommela R, Russak S, Makinen PL, Vahlberg T, Falony G, Makinen K, Honkala E (2014) Effect of Erythritol and Xylitol on Dental Caries Prevention in Children. Caries Res 48 (5):482-490. doi:10.1159/000358399

28. Ching TL, Haenen GR, Bast A (1993) Cimetidine and other H2 receptor antagonists as powerful hydroxyl radical scavengers. Chem Biol Interact 86 (2):119-127

29. Shen B, Jensen RG, Bohnert HJ (1997) Mannitol Protects against Oxidation by Hydroxyl Radicals. Plant Physiol 115 (2):527-532

30. den Hartog GJ, Boots AW, Adam-Perrot A, Brouns F, Verkooijen IW, Weseler AR, Haenen GR, Bast A (2010) Erythritol is a sweet antioxidant. Nutrition 26 (4):449-458. doi:S08999007(09)00227-5 [pii]

10.1016/j.nut.2009.05.004

31. Yokozawa T, Kim HY, Cho EJ (2002) Erythritol attenuates the diabetic oxidative stress through glucose metabolism and lipid peroxidation in streptozotocin-induced diabetic rats. Journal of Agricultural and Food Chemistry 50:5485-5489

32. Furchgott RF, Jothianandan D (1991) Endothelium-Dependent and -Independent Vasodilation Involving Cyclic GMP: Relaxation Induced by Nitric Oxide, Carbon Monoxide and Light. Journal of Vascular Research 28 (1-3):52-61

33. Grieve DJ, Avella MA, Botham KM, Elliott J (1998) Effects of chylomicrons remnants on endothelium-dependent relaxation of rat aorta. European Journal of Pharmacology 348:181-190

34. Praticò D (2005) Antioxidants and endothelium protection. Atherosclerosis 181 (2):215-224

35. Roberts AC, Porter KE (2013) Cellular and molecular mechanisms of endothelial dysfunction in diabetes. Diabetes and Vascular Disease Research. doi:10.1177/1479164113500680

36. Boesten DMPHJ, Berger A, de Cock P, Dong H, Hammock BD, den Hartog GJM, Bast A (2013) Multi-Targeted Mechanisms Underlying the Endothelial Protective Effects of the Diabetic-Safe Sweetener Erythritol. PLoS One 8 (6):e65741. doi:10.1371/journal.pone.0065741

37. Weseler AR, Ruijters EJB, Drittij-Reijnders M-J, Reesink KD, Haenen GRMM, Bast A (2011) Pleiotropic Benefit of Monomeric and Oligomeric Flavanols on Vascular Health - A Randomized Controlled Clinical Pilot Study. PLoS One 6 (12):e28460. doi:10.1371/journal.pone.0028460

38. Weseler AR, Bast A (2012) Pleiotropic-acting nutrients require integrative investigational approaches: the example of flavonoids. J Agric Food Chem 60 (36):8941-8946. doi:10.1021/jf3000373

39. Flint N, Hamburg N, Holbrook M, Dorsey P, LeLeiko R, Berger A, de Cock P, Bosscher D, Vita J (2013) Effects of erythritol on endothelial function in patients with type 2 diabetes mellitus: a pilot study. Acta Diabetol:1-4. doi:10.1007/s00592-013-0534-2 
Chapter 6

\title{
Multi-targeted mechanisms underlying the endothelial protective effects of the diabetic-safe sweetener erythritol
}

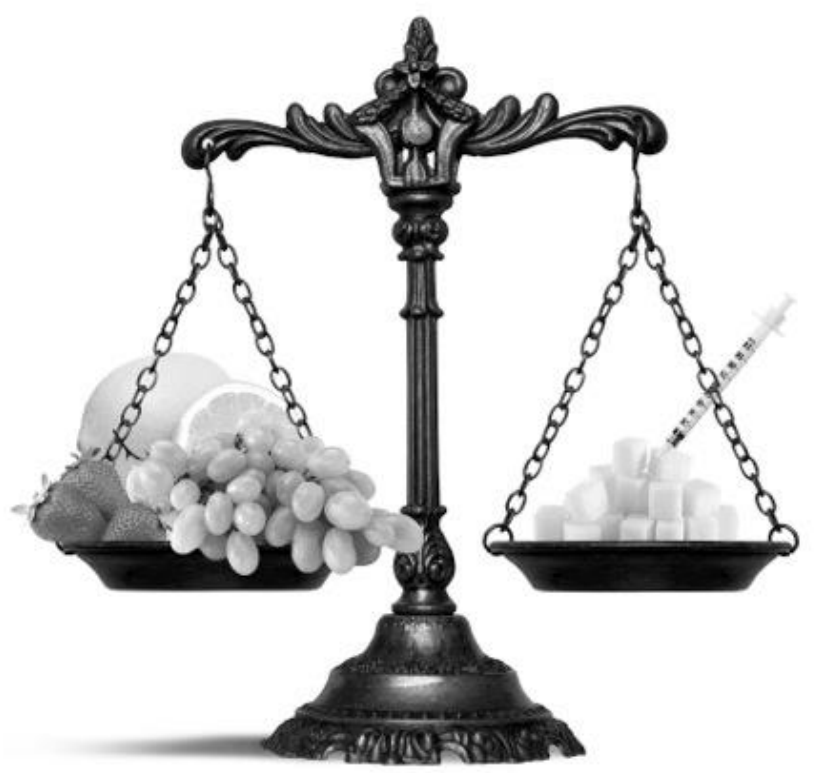

\author{
Daniëlle M.P.H.J. Boesten \\ Alvin Berger ${ }^{*}$ \\ Peter de Cock \\ Hua Dong \\ Bruce D. Hammock \\ Gertjan J.M. den Hartog \\ Aalt Bast
}

PLoS One. 2013;8:e65741 (*These authors contributed equally to this work) 


\begin{abstract}
Diabetes is characterized by hyperglycemia and development of vascular pathology. Endothelial cell dysfunction is a starting point for pathogenesis of vascular complications in diabetes. We previously showed the polyol erythritol to be a hydroxyl radical scavenger preventing endothelial cell dysfunction onset in diabetic rats. To unravel mechanisms, other than scavenging of radicals, by which erythritol mediates this protective effect, we evaluated effects of erythritol in endothelial cells exposed to normal $(7 \mathrm{mM})$ and high glucose $(30 \mathrm{mM})$ or diabetic stressors (e.g. SIN-1) using targeted and transcriptomic approaches. This study demonstrates that erythritol (i.e. under non-diabetic conditions) has minimal effects on endothelial cells. However, under hyperglycemic conditions erythritol protected endothelial cells against cell death induced by diabetic stressors (i.e. high glucose and peroxynitrite). Also a number of harmful effects caused by high glucose, e.g. increased nitric oxide release, are reversed. Additionally, total transcriptome analysis indicated that biological processes which are differentially regulated due to high glucose are corrected by erythritol. We conclude that erythritol protects endothelial cells during high glucose conditions via effects on multiple targets. Overall, these data indicate a therapeutically important endothelial protective effect of erythritol under hyperglycemic conditions.
\end{abstract}




\section{Introduction}

Chronic hyperglycemia in diabetes is associated with cardiovascular disease and microvascular pathologies in the retina, kidney and peripheral nerves $(1 ; 2)$. Most of these diabetic complications find their origin in damaging of the endothelium, a layer of cells lining the cardiovascular system (3-5). The endothelium participates in numerous normal physiological functions including control of vasomotor tone, maintenance of blood fluidity, regulation of permeability, formation of new blood vessels and trafficking of cells. The endothelium also plays an important role in several human diseases. During inflammation, genes become activated within the endothelium to facilitate recruitment, attachment, and transmigration of inflammatory cells. In chronic inflammatory diseases, endothelial cell responses become impaired, leading to endothelial dysfunction (ED) $(1 ; 6)$.

Erythritol (1,2,3,4-butanetetrol; ERT) is a natural C4 polyol that has a sweetness of $60-80 \%$ that of sucrose. More than $90 \%$ of ingested ERT is not metabolized by humans and excreted unchanged in urine, indicating ERT is efficiently absorbed not metabolized for energy and excreted by renal processes $(7 ; 8)$. It is a suitable bulk sweetener because it is not metabolized, does not influence blood glucose or insulin levels and does not cause caries $(9 ; 10)$, consequently it is also safe for diabetics.

We have previously shown that ERT is an excellent hydroxyl radical scavenger in vitro and that it also delayed radical-induced hemolysis in red blood cells (11). Supplementation with ERT reduced lipid peroxidation (8) and prevented loss of endothelium-dependent vasorelaxation in a diabetic rat model (11). Given the importance of the endothelium in regulating vascular function and initiation and propagation of inflammatory responses to high glucose, herein, we extend our previous studies with rats (11) by evaluating effects of ERT in an endothelial cell line exposed to normal and high glucose concentrations, using targeted and transcriptomic approaches.

\section{Material and Methods}

\section{Chemicals}

Erythritol was kindly provided by Cargill (Vilvoorde, Belgium). F12K medium and fetal calf serum (FCS) were obtained from ATCC (Wesel, Germany). Penicillin/streptomycin, Hank's Balanced Salt Solution (HBSS) and trypsin were purchased from Gibco (Breda, The Netherlands). Glucose, $N^{G}$-nitro-L-arginine 
methyl ester (L-NAME), 2-thiobarbituric acid (TBA), phosphoric acid, Ethylenediaminetetraacetic acid (EDTA), butylated hydroxytoluene (BHT), ethylene glycol tetraacetic acid (EGTA), nuclease P1, alkaline phosphatase, calcium ionophor A23187 and 4,5-diaminofluorescein diacetate (DAF-2) were obtained from Sigma Aldrich (Steinheim, Germany). 3-morpholino sidnonimine (SIN-1) was acquired from Alexis Biochemicals (San Diego, CA, USA). Endothelial cell growth supplement (ECGS) was obtained from BD Bioscience (Breda, The Netherlands). Heparin was purchased from Leo Pharmaceuticals (Amsterdam, The Netherlands). Ethanol, methanol and butanol were acquired from Biosolve (Valkenswaard, The Netherlands). [ $\left.{ }^{3} \mathrm{H}\right]$-arginine was obtained from Perkin Elmer (Waltham, MA, USA).

\section{Cell Culture}

Human umbilical vein endothelial (HUVEC) cell line CRL-1730 was obtained from ATCC. HUVECs were cultured in F12K medium with $10 \%$ non-heat inactivated FCS, $1 \%$ penicillin/streptomycin, $0.05 \mathrm{mg} / \mathrm{ml}$ ECGS and $0.1 \mathrm{mg} / \mathrm{ml}$ heparin. Cells were maintained in collagen coated T75 flasks (Greiner Bio-one, Alphen a/d Rijn, The Netherlands) at $37^{\circ} \mathrm{C}$ in a $5 \% \mathrm{CO} 2$ atmosphere. For experiments, cells were seeded in 6 well plates/T75 flasks and grown until 80\% confluency. Next, medium was removed and cells were washed with HBSS. New medium without supplements and erythritol (final concentration $5 \mathrm{mM}$ ), L-NAME (final concentration $0.1 \mathrm{mM}$ or 0.5 $\mathrm{mM}$ ) or vehicle solution (medium) was added to the cells. After 1 hour incubation glucose (final concentration $30 \mathrm{mM}$ glucose) or vehicle (medium) was added to the cells. Subsequently, cells were incubated for 24 hours. The same protocol was used for incubation with SIN-1 (final concentration $0.5 \mathrm{mM}$ ).

\section{Cell viability}

HUVEC cells were grown in 6 well plates until $80 \%$ confluence. After incubation medium was removed, the cells were washed with HBSS and harvested with trypsin. All cell material including medium and HBSS was collected and centrifuged ( 5 minutes, $500 \mathrm{xg}$ ) and used to determine viability of the cells using the trypan blue exclusion assay. The percentage of dead cells was calculated with the formula: (dead cells / (dead cells + viable cells) $* 100 \%$.

\section{Malondialdehyde measurement}

Malondialdehyde (MDA) was measured with HPLC. Briefly, $100 \mu \mathrm{l}$ of cell lysate or MDA standard were mixed with $1 \mathrm{ml}$ of reagent, composed of 10 parts reagent $A$ (12 mM TBA, $0.32 \mathrm{M}$ phosphoric acid and $0.01 \mathrm{mM}$ EDTA) and one part of reagent $B$ $\left(1.5 \mathrm{mg} / \mathrm{ml} \mathrm{BHT}\right.$ in ethanol). Samples and standards were heated for 1 hour at $99^{\circ} \mathrm{C}$. After cooling, $500 \mu \mathrm{l}$ of butanol was added and samples and standards were 
centrifuged for 5 minutes at maximum speed to extract the TBA-MDA product. Ten $\mu \mathrm{l}$ of the extract was injected on to an Alltima HP C18 column (Grace, Breda, The Netherlands) and eluted with $65 \%$ water and $35 \%$ methanol with $0.1 \%$ trifluoroacetic acid. Fluorescence was recorded at $\lambda_{\text {ex }} 532 \mathrm{~nm} / \lambda_{\text {em }} 553 \mathrm{~nm}$. MDA concentration was determined by calculating the peak height of the TBA-MDA product and results were corrected for protein content of the lysates.

\section{Protein carbonyl measurement}

Cell lysates were monitored for their protein carbonyl contents using the protein carbonyl assay kit (Cayman Chemical, Ann Arbor, MI, USA). 2,4Dinitrophenylhydrazine (DNPH) reacted with protein carbonyls in the lysate. The amount of protein-hydrozone produced was then quantified spectrophotometrically at an absorbance of $385 \mathrm{~nm}$. The carbonyl content was corrected for protein content of the lysates.

\section{8-Hydroxydeoxyguanosine measurement}

DNA was extracted from HUVEC cells using the QIAamp DNA Mini Kit (Qiagen, Venlo, The Netherlands) according to the manufacturer's protocol and quantified spectrophotometrically. After extraction, $15 \mu \mathrm{g}$ DNA was digested into deoxyribonucleosides by treatment with nuclease P1 $(0.02 \mathrm{U} / \mu \mathrm{l})$ and alkaline phosphatase $(0.014 \mathrm{U} / \mu \mathrm{l})$. To measure oxidative damage of DNA by $8-\mathrm{OHdG}$ the Bioxytech 8-OHdG-EIA kit (Oxis Health products, Beverly Hills, CA, USA) was used. Digested samples were added to the microtitre plate precoated with $8-\mathrm{OHdG}$ and the assay was performed according to the manufacturer's instructions.

\section{NOS3 activity}

NOS3 activity was determined as described previously (12-14) using the NOS activity assay kit from Cayman. NOS3 activity was determined in cell pellets which were homogenized in ice-cold $25 \mathrm{mM}$ Tris- $\mathrm{HCl}$ buffer containing $1 \mathrm{mM}$ EDTA and 1 mM EGTA. Next, $22 \mu \mathrm{M}\left[{ }^{3} \mathrm{H}\right]$-arginine (specific activity: $43 \mathrm{Ci} / \mathrm{mmol}$ ) and $1 \mathrm{mM}$ calcium chloride, $6 \mu \mathrm{M}$ tetrahydrobiopterin, $2 \mu \mathrm{M}$ flavin adenine mononucleotide and $1 \mathrm{mM}$ of reduced nicotinamidedinucleotide phosphate as co-factors was added to the homogenate. After 60 minutes incubation at room temperature, the reaction was stopped by adding a slightly acidic HEPES buffer containing a calcium ion chelator. $\left[{ }^{3} \mathrm{H}\right]$-arginine was separated from $\left[{ }^{3} \mathrm{H}\right]$-citrulline by DOWEX ion exchange resin. Scintilliation fluid was added and samples were counted for 5 minutes in a Wallac Liquid Scintillation counter. Background counts were determined by adding $\left[{ }^{3} \mathrm{H}\right]$-arginine to the DOWEX resin and determining the remaining counts. Total counts were obtained by adding $\left[{ }^{3} \mathrm{H}\right]$-arginine to the HEPES 
buffer and determining the counts. NOS3 activity was then determined by calculating the conversion percentage by $\%$ conversion $=((\mathrm{dpm}$ reaction $-\mathrm{dpm}$ background)/dpm total) $\times 100$ after which the formed amount of $\left[{ }^{3} \mathrm{H}\right]$-citrulline could be calculated. This value was then transformed into units of NOS3 activity per milligram protein ( 1 unit = 1 micromole of citrulline per minute).

\section{Nitric oxide release}

Quantification of nitric oxide (NO) released by the HUVEC was performed by using the DAF-2 fluorescence assay as described by Rathel et al (15). HUVECs were grown in 6 well plates until $80 \%$ confluence. After incubation, cells were washed twice with $\mathrm{PBS}+\mathrm{Ca}^{2+}$. Subsequently, cells were incubated with $\mathrm{PBS}+\mathrm{Ca}^{2+}$ containing 100 $\mu \mathrm{M}$ L-arginine for 10 minutes at $37^{\circ} \mathrm{C}$. Afterwards, the calcium ionophor A23187 and DAF- 2 were added into the buffer at final concentrations of respectively $1 \mu \mathrm{M}$ and $0.1 \mu \mathrm{M}$. Next, cells were incubated in the dark for another 30 minutes at $37^{\circ} \mathrm{C}$. Cell supernatants were then transferred into an opaque 96-well plate and fluorescence was measured on a spectrofluorometer (Spectra Max M2, Molecular Devices) with $\lambda_{\text {ex }}$ set at $495 \mathrm{~nm}$ and $\lambda_{\text {em }}$ at $515 \mathrm{~nm}$. The NO release was corrected for protein content of the measured wells.

\section{Gene expression analysis}

RNA was isolated from Qiazol suspended cells according to the manufacturer's protocol and quantified spectrophotometrically. Reverse transcription reaction was performed using $500 \mathrm{ng}$ of RNA, which was reverse-transcribed into cDNA using iScript $^{\text {TM }}$ cDNA synthesis kit (Biorad, Veenendaal, The Netherlands). Next, real time PCR was performed with a BioRad MyiQ iCycler Single Color RT-PCR detection system using Sensimix ${ }^{T M}$ Plus SYBR and Fluorescein (Quantace-Bioline, Alphen a/d Rijn, The Netherlands), $5 \mu$ diluted (10x) cDNA, and $0.3 \mu \mathrm{M}$ primers in a total volume of $25 \mu \mathrm{l}$. PCR was conducted as follows: denaturation at 95 으 for 10 minutes, followed by 40 cycles of $95^{\circ} \mathrm{C}$ for 15 seconds and $60^{\circ} \mathrm{C}$ for 45 seconds. After PCR a melt curve (60-95ㅇ) was produced for product identification and purity. $\beta$-actin was included as internal control. Primer sequences for $\beta$-actin were: forward 5'-CCTGGCACCCAGCACAAT-3' and reverse 5'-GCCGATCCACACGGAGTACT3' and for NOS3 forward 5'-GAGGGGAGCTGTTGTAGGG-3' and reverse 5'GTGGTAACCAGCACATTTGG-3'. Data were analysed using the MylQ software system (BioRad) and were expressed as relative gene expression (fold change) using the $2^{\Delta \Delta C t}$ method.

\section{Protein determination}

Protein concentrations were determined spectrophotometrically using the 
DCprotein assay kit (BioRad) according to the manufacturer's protocol.

\section{Eicosanoid measurement}

Eicosanoids (or oxylipins) derived from cyclooxygenase-, lipoxygenase- and cytochrome P450- enzymes, including those associated with hypertension and ED, were measured after published methods $(16 ; 17)$ in cell pellets (nmol/g protein) and culture medium (nM). The 23 eicosanoids measured included 12,13-DiHOME, 9,10-DiHOME, 14,15-DiHETrE, 11,12-DiHETrE, 8,9-DiHETrE, 5,6-DiHETrE, 9(10)EpOME, 12(13)-EpOME, 14(15)-EpETrE, 11(12)-EpETrE, 8(9)-EpETrE, 5(6)-EpETrE, $\mathrm{TXB}_{2}, \mathrm{PGE}_{2}, \mathrm{PGD}_{2}, \mathrm{PGF}$ ?? $\mathrm{LTB}_{4}$, 5-HETE, 8-HETE, 11-HETE, 12-HETE, and 15-HETE [for abbreviations', see Table S1 in (18)].

\section{RNA isolation and microarray experiments}

Total RNA was isolated from Qiazol ${ }^{\circledR}$ suspended cells according to the manufacturer's protocol, followed by a clean-up, using a RNAeasy Mini Kit (Qiagen) with DNase treatment. RNA quantity and purity were determined spectrophotometrically using a Nanodrop. RNA quality was further assessed by automated gel electrophoresis on an Agilent 2100 Bioanalyzer (Agilent Technologies, Amstelveen, The Netherlands). All samples were found to be pure and free of RNA degradation. Sample preparation, hybridization, washing, staining and scanning of the Affymetrix Human Genome U133 Plus 2.0 GeneChip arrays (Affymetrix, Santa Clara, CA, USA) were conducted according to the manufacturer's manual. Quality controls were within accepted limits.

\section{Data processing and statistical analysis}

Microarray data was processed using $\mathrm{R}$ and packages from the Bioconductor repository, including affy (19-21). Probe sets and annotations were updated using the Entrez Gene based re-annotation by the BrainArray group (22). The RMA algorithm was used to obtain background corrected, normalized, and logtransformed intensities for each probe set (23). Genes that had low intensity signals (2log 100) on each array were removed before further processing. Determination of differentially expressed genes between relevant experimental groups was performed using the R limma package (24). Regression models were built correcting for the day of the run and including an interaction term between ERT treatment status and glucose level.

\section{Data mining}

Commercial and public domain database tools were used to annotate the changed transcripts. These included: the Gene Ontology (GO) database Transcript2GO; 
GeneSpring (Agilent Technologies, Inc., Santa Clara, CA, USA) for promoter analysis, transport factors and conservative natural language processing on Mesh terms and key words; ExPASy for reactions; DAVID for enzyme EC linking; Reactome for reactions amongst transcipts; and PhosphoSitePlus and GeneCards for annotations and transcript descriptions. The two main effects examined in pathway analysis were high glucose (30 mM, HG) vs normal glucose ( $7 \mathrm{mM}, \mathrm{NG})$ and particularly high glucose in combination with pre/coincubation with $5 \mathrm{mM}$ erythritol (HGERT) vs HG. Normal glucose in combination with pre/coincubation with ERT vs NG was investigated minimally for pathway and network analysis. Pathway analysis was performed with PathVisio 2.0.7 (25) (www.pathvisio.org) using filtered microarray expression data and pathway collections from KEGG and WikiPathways (www.wikipathways.org). GeneSpring was also utilized to identify major pathways.

\section{Statistical analysis}

For all analyses, p-values were calculated for the following comparisons: HGERT vs. HG (HGERT/HG); NGERT vs. NG (NGERT/NG); and HG vs. NG (HG/NG) (HG, high glucose; NG, normal glucose). For targeted analyses, there were 3 replications and data were evaluated by ANOVA models and student's t-tests for each of the above three comparisons. P-values $<0.05$ were considered statistically significant. P-values $<0.1$ were considered statistical trends, and are also described, since sample sizes were small (typically $n=3$ ), and in some cases, assay variation was high.

\section{Results}

\section{Erythritol attenuates glucose induced cell death}

The effect of incubating HUVECs with HG, ERT or a combination of ERT and glucose (HGERT) was investigated by evaluating the cell viability using the trypan blue exclusion assay.

When HUVECs were incubated with HG for 24 hours the percentage of dead cells increased almost 4 -fold ( $p=0.0002$ ) without affecting total cell number (Figure 1 ). Addition of ERT or the nitric oxide synthase (NOS) inhibitor L-NAME (0.1 mM or 0.5 $\mathrm{mM}$ ) completely prevented this increase in the percentage of dead cells ( $p=0.002$ for ERT; $p=0.003$ and $p=0.001$ for L-NAME). Longer HG incubation (48 hours) resulted in a dramatically lower total cell number (inset figure $1 \mathrm{C}$ ). Incubation for 24 hours with the peroxynitrite-generating compound SIN-1 also significantly increased cell death which was attenuated by addition of $5 \mathrm{mM}$ ERT ( $p=0.03$ and $\mathrm{p}=0.06$ ). Moreover, under normal glucose conditions incubation with ERT did not result in an increased cell death compared to incubation without ERT. 

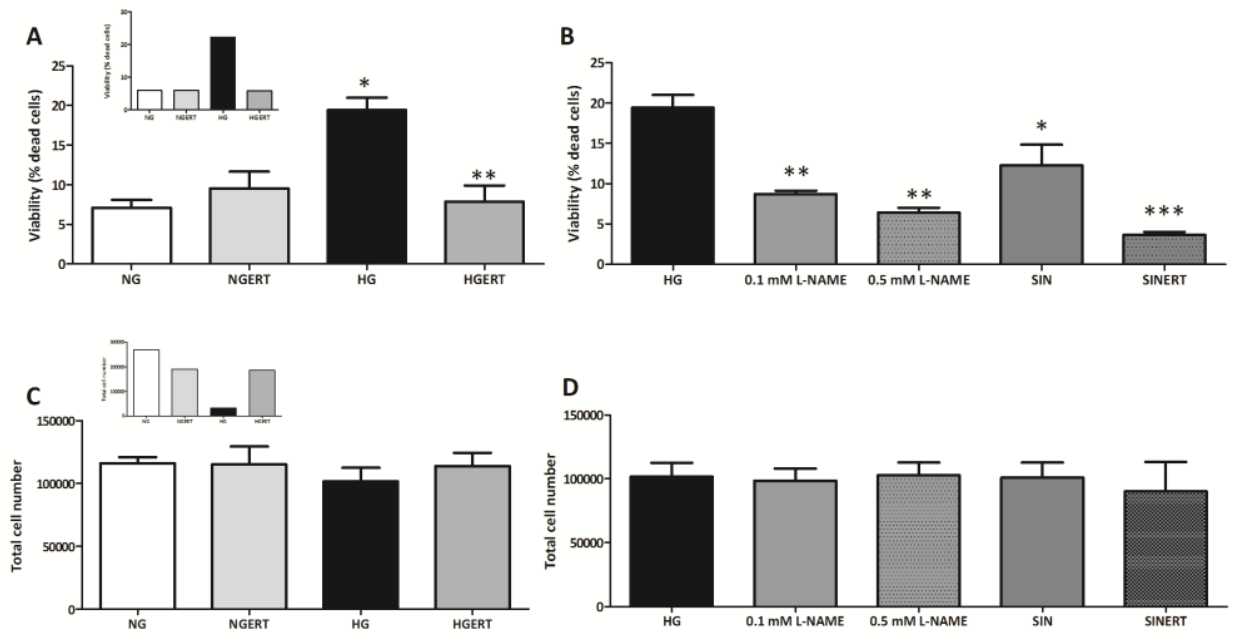

Figure 1: Erythritol attenuates cell death induced by diabetic stressors. Effect on viability of HUVECs incubated with normal glucose (NG, $7 \mathrm{mM}$ ) or high glucose (HG, $30 \mathrm{mM}$ ) in the presence or absence of erythritol (ERT, $5 \mathrm{mM}$ ) for 24 hours (A). Effect on viability of HUVECs incubated with $\mathrm{HG}$ in the presence of $\mathrm{N}^{G}$-nitro-L-arginine methyl ester (L-NAME, $0.1 \mathrm{mM}$ and $0.5 \mathrm{mM}$ ) and 3-morpholino sidnonimine (SIN, $0.5 \mathrm{mM}$ ) in the presence or absence of ERT (B) Effect of incubations on total cell number after 24 hours ( $C$ and $D)$. Inset show data of 48 hour incubation with ERT, HG or HGERT $(n=1)$. Data are expressed as means \pm standard error of at least three independent experiments. ${ }^{*}=p<0.05$ compared to NG; ${ }^{* *}=p<0.05$ compared to HG; ${ }^{* * *}=\mathrm{p}<0.1$ compared to $\mathrm{SIN}$.

\section{Effects on oxidative stress parameters}

Because hyperglycemia is strongly associated with oxidative stress, we investigated three parameters of oxidative stress. Firstly, the protein carbonyl content of the HUVECs was measured. Protein carbonyls are products of the reaction between proteins and reactive oxygen species. Though not significant, a trend toward higher carbonyl content was visible after incubation with HG compared to NG incubation for 24 hours (figure 2B). Addition of $5 \mathrm{mM}$ ERT showed a trend toward a lower protein carbonyl content $(p=0.09)$. Next, the amount of malondialdehyde (MDA) in HUVECs was assessed. MDA is one of the end products of lipid peroxidation, a chain reaction in membrane lipids initiated by reactive oxygen species. Figure $2 \mathrm{~A}$ indicates that incubation with $5 \mathrm{mM}$ ERT, HG and HGERT does not increase the amount of MDA compared with HUVECs incubated with NG. Finally, the amount of oxidized nucleotide, in the form of 8hydroxydeoxyguanosine $(8-\mathrm{OHdG})$ was determined. Incubation with HG for 24 hours did not increase the amount of $8-\mathrm{OHdG}$ (figure $2 \mathrm{C}$ ). Furthermore, incubation 


\section{Chapter 6}

with 5 mM ERT with either NG or HG did not have an effect on the amount of 8OHdG in HUVECs.
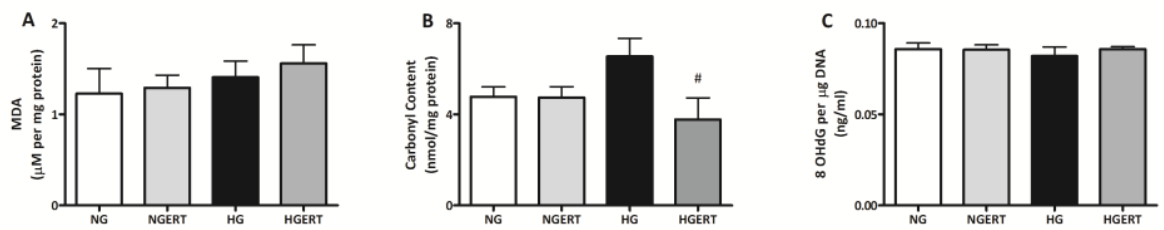

Figure 2: Effect on oxidative stress parameters. Effect of pre/coincubation with $5 \mathrm{mM}$ erythritol (ERT) on HUVECS cultured in normal glucose (NG, $7 \mathrm{mM}$ ) or high glucose (HG, 30 $\mathrm{mM}$ ) for 24 hours on malondialdehyde (A), carbonyl (B) and 8-OHdG (C) content. Data are expressed as means \pm standard error of three independent experiments. $\#=p<0.1$ compared to HG.

\section{Effects on endothelial function}

Production of the vasoactive gaseous radical nitric oxide (NO) by NOS is one of the most important functions of the endothelium. In the endothelium this is predominantly the NOS3 isoform $(3 ; 26)$. Therefore, we investigated the production of NO by HUVECs, which is shown in Figure 3A. When HUVECs were exposed to HG for 24 hours a 3-fold increase in NO release was observed $(p=0.04)$. Pre/coincubation with ERT showed a trend toward lower NO production $(p=0.06)$ compared to HG alone. Additionally, we looked at the effect of ERT on NOS3 activity in lysates from HUVECs exposed to HG (figure 3B). No difference between the conditions was observed. High variability (either biological or assay specific) may have prevented changes from being statistically different. Figure $3 C$ shows an increase in gene expression of NOS3 after 24 hours under HG conditions $(p=0.03)$, which was attenuated by ERT $(p=0.1)$.
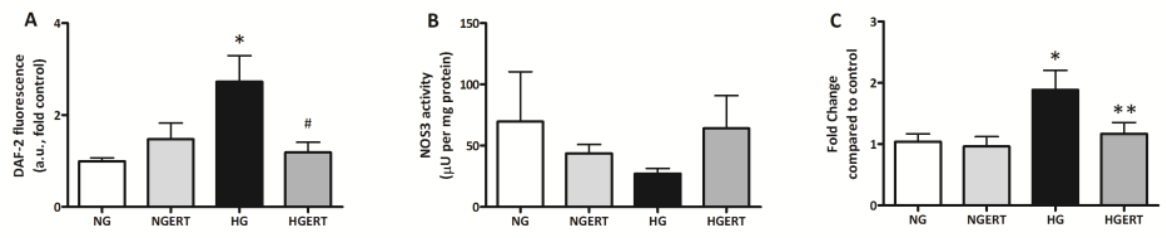

Figure 3: Effect on endothelial cell parameters. Effect of pre/coincubation with $5 \mathrm{mM}$ erythritol (ERT) on HUVECS cultured in normal glucose (NG, $7 \mathrm{mM}$ ) or high glucose (HG, 30 $\mathrm{mM}$ ) for 24 hours on NO release (A), NOS3 activity (B) and NOS3 gene expression (C). Data are expressed as means \pm standard error of at least three independent experiments. ${ }^{*}=$ p $<0.05$ compared to NG; ${ }^{* *}=p<0.05$ compared to HG; $\#=p<0.1$ compared to HG. 


\section{Eicosanoid analysis}

Eicosanoids formed from polyunsaturated fatty acids via classical cyclooxygenase and lipoxygenase pathways, as well as P450-derived epoxyeicosatreinoic acids (EETs) formed via soluble epoxide hydrolase $(\mathrm{sEH})$ were measured in both cell pellets and culture medium (Figure 4 and supporting table 1 ). Thromboxane $B_{2}$ $\left(T_{X B_{2}}\right)$ was increased in pellets of cells exposed to HGERT compared to HG alone in pellets $(p=0.03)$. Both 8 -HETE $(p=0.05)$ and 12-HETE $(p=0.03)$ were decreased in pellets from cells exposed to HGERT compared to HG alone. In supernatants we only found a decrease of excretion of 14,15-dihydroxy-5Z,8Z,11Z-eicosatrienoate (14,15-DiHETrE) by cells exposed to HGERT compared to cells exposed to only HG $(p=0.04)$. Cells incubated with ERT excreted more 12,13-Dihydroxyoctadecenoic acid (12,13-DiHOME; $p=0.01$ ) and showed a trend towards less prostaglandin $E_{2}$ $\left(P E_{2} ; p=0.06\right)$ and prostaglandin $D_{2}\left(P G D_{2} ; p=0.05\right)$ excretion compared to cells incubated without ERT.
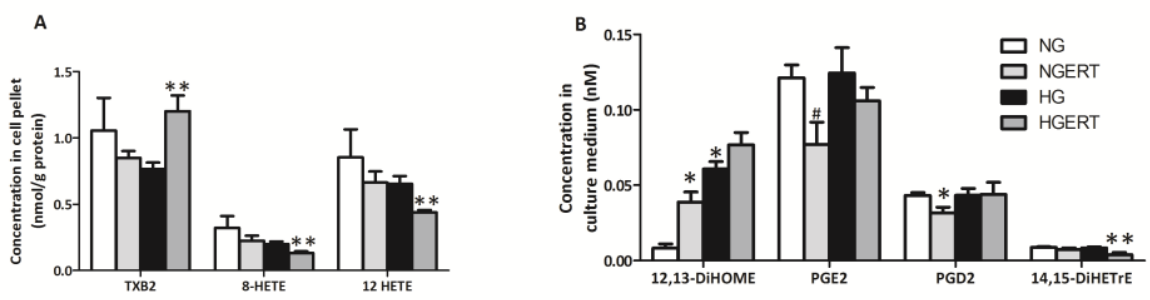

Figure 4: Effect on eicosanoid concentrations. Effect of pre/coincubation with $5 \mathrm{mM}$ erythritol (ERT) on HUVECS cultured in normal glucose (NG, $7 \mathrm{mM}$ ) or high glucose (HG, 30 $\mathrm{mM}$ ) for 24 hours on eicosanoid concentrations in cell pellets (A) and culture medium (B). Data are expressed as means \pm standard error of three independent experiments. ${ }^{*}=p<0.05$ compared to NG; ${ }^{* *}=p<0.05$ compared to HG; $\#=p<0.1$ compared to HG.

\section{Transcriptomic analysis}

The numbers and overlap of transcripts changed in response to three comparisons are shown by Venn diagram (Figure 5).

ERT induced small but significant fold changes in many transcripts. Maximum fold changes for down regulation were 0.94-0.97; and for up regulation were 1.04-1.13. There were 521 transcripts changed in response to HGERT vs. HG (HGERT/HG; $\mathrm{p}<0.05$ ). Numbers of transcripts down- and upregulated was similar (296 down, 225 up). Comparing NGERT to NG (NGERT/NG), 194 transcripts changed. Only 6 transcripts changed in common for HGERT/HG and NGERT/NG, often with a different directionality, and did not change in response to HG/NG. Without ERT, HG 


\section{Chapter 6}

alone (HG/NG) altered 434 transcripts. A striking observation was that under HG conditions, ERT reversed direction of change in 148 of the 153 transcripts changing in common with HGERT/HG and HG/NG, suggesting potential benefits of using ERT to ameliorate pathologies associated with hyperglycemia (figure 6). A subset of transcripts (368) were uniquely affected by HGERT/HG but not HG alone (HG/NG).

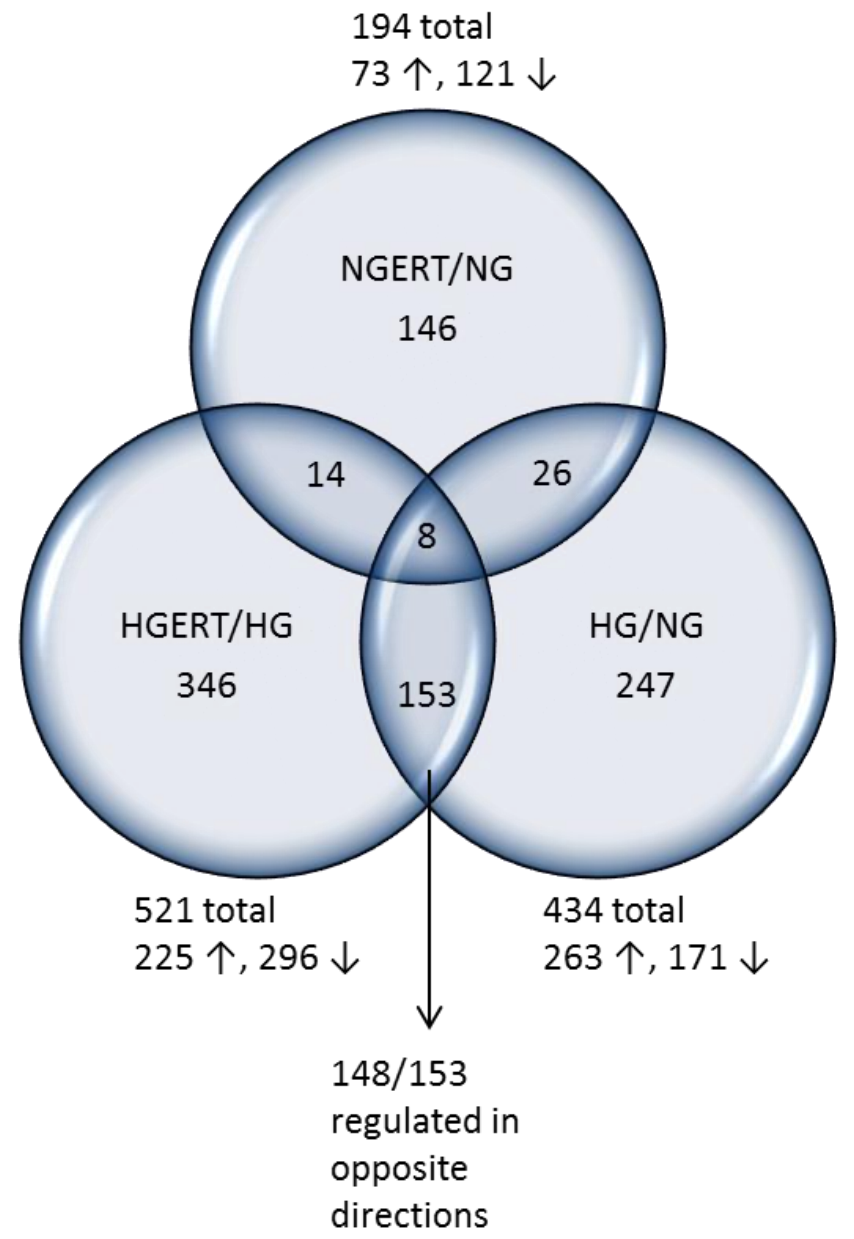

Figure 5: Venn diagram of changed transcripts. Venn diagram showing the overlap of differentially expressed transcripts after pre/coincubation with or without $5 \mathrm{mM}$ erythritol (ERT) of HUVECs cultured in normal glucose (NG, $7 \mathrm{mM}$ ) or high glucose (HG, $30 \mathrm{mM}$ ) for 24 hours. Changed transcripts of the following comparisons are shown: HGERT vs HG (HGERT/HG); NGERT vs NG (NGERT/NG) and HG vs NG (HG/NG). 

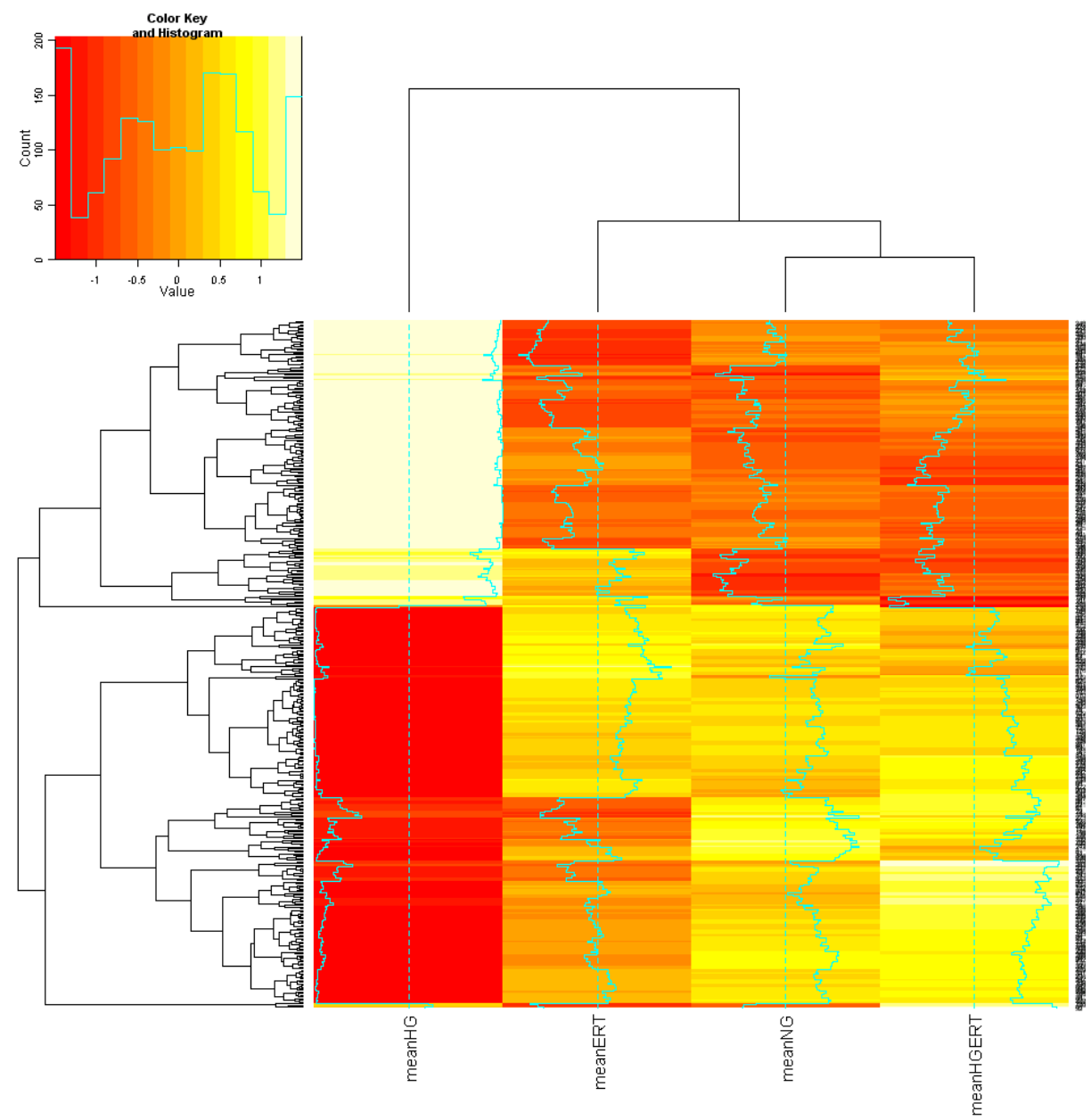

Figure 6: Heat map of transcriptomic analysis. Heat map reflecting the mean gene expression values in the four different treatment groups: From left to right: high glucose (HG, $30 \mathrm{mM}$ ), normal glucose and $5 \mathrm{mM}$ erythritol (NGERT), normal glucose (NG), high glucose and $5 \mathrm{mM}$ erythritol (HGERT). Cluster analysis shows that the expression profile in the HG group differs from the other three treatment group that form a separate cluster.

\section{Discussion}

With this study we want to identify the mechanism(s) by which ERT exerts its endothelium-protective effect during diabetic stress, previously demonstrated in a diabetic rat model (11). Hydroxyl radical scavenging by ERT alone cannot explain the powerful in vivo protective effects. Therefore the potential protective effects of ERT were investigated in different areas via targeted (e.g. cell viability, oxidative stress parameters, endothelial function parameters) and transcriptomic profiling in 
HUVECs. This cell line was chosen as a model because it has been used in a number of scientific studies into vascular inflammation, endothelial dysfunction and effects of hyperglycemia (27-31).

The induction of apoptotic endothelial cell death by HG has often been described $(32 ; 33)$ and is highly implicated in the development of diabetic complications. We showed that exposure of HUVECs to HG increased the number of dead cells, which could be prevented by ERT. This higher number of death cells under HG conditions seems to be caused by an increase in NO, because addition of the NOS inhibitor LNAME under HG conditions decreased the amount of dead cells. The involvement of NO in glucose toxicity has been described previously (34-36). Another indication of the involvement of NO in endothelial cell dead was found when HUVECs were incubated with the peroxynitrite generator SIN-1. We showed that SIN-1 induced cell death, which was attenuated by ERT. Specifically for endothelial cells during diabetes, this is an important finding since peroxynitrite formation is likely to be increased during diabetes. Peroxynitrite is generated by the reaction of superoxide radicals with nitric oxide (37), the production of these precursors is known to be increased during diabetes $(38 ; 39)$. Peroxynitrite can induce lipid peroxidation and protein nitrosylation and thus plays a role in diabetes related tissue damage (40). In a previous study, ERT was shown to have peroxynitrite scavenging activity in an in vitro system (41).

Subsequently, we looked at the ability of ERT to reduce oxidative damage caused by HG in HUVECs. Many studies have demonstrated that hyperglycemia triggers oxidative stress and generation of free radicals $(1 ; 33 ; 42 ; 43)$. These radicals cause damage to membranes, proteins and DNA resulting in cellular dysfunction and death. Radical scavenging by ERT reduces damage which may contribute to its endothelial protective effect. In HUVECs exposure to HG resulted in higher protein carbonyl levels while MDA and $80 \mathrm{HdG}$ levels were not increased. This indicates that oxidative damage in HUVECs due to $H G$ is concentrated in the cytosol. Since the majority of the proteins in the cell are located in the cytosol and therefore in the vicinity of the source of the high-glucose-induced oxygen radicals, it is likely that oxidative damage will probably be noted first as oxidized proteins as we observed with these results.

ERT did not affect NOS3 activity in HUVECs. Remarkably, the release of nitric oxide and the expression of the NOS3 gene were increased after incubation with high glucose only. This is in perfect agreement with the observation of Pandolfi and many others, who observed that HUVECs from human and animal origin display 
increased NO production and NOS3 gene expression $(39 ; 44)$. How this relates to endothelial dysfunction, which is commonly regarded to be the result of impaired NO production, is currently unknown, although it has been suggested that the increased NO levels influence the transcription of genes that affect adenosine uptake by endothelial cells (39).

Eicosanoids are potent inflammatory mediators triggered by oxidative stress and/or hyperglycemia. Even small changes in amount of these bioactive molecules could be biologically important. Differences in concentration of TXB $\mathrm{T}_{2}, 8$-HETE and 12-HETE were observed in cell pellets. Especially the decrease of 12-HETE in presence of ERT is of interest since it is a pro-inflammatory molecule produced from arachidonic acid via 12-lipoxygenase (12-LO) (45). Oxidative stress and HG incubations of endothelial cells have been shown to increase 12-HETE and diabetic pigs with elevated blood glucose have increased 12-HETE (46). In monocytes, HG increased 12-HETE and monocyte adhesion to endothelial cells via monocytic production of integrins (47). In endothelial cells, 12-HETE induced integrin production in a PKC-dependent manner (48). Exposure of endothelial cells to 12 HETE decreased production of vasodilatory $\mathrm{PGI}_{2}$ (49). In culture medium we found differences in 14,15-DiHETrE which is produced from arachidonic acid via Cyp $2 \mathrm{C}$ and $2 \mathrm{~J}$ to form EETs, which are in turn converted to DiHETrE via SEH. The decrease in 14,15-DiHETrE we found is consistent with HG suppression of $\mathrm{SEH}$ (50), resulting in increased EETs and EET-induced vasodilation. EETs were not observed to be increased in our system. Comparing ERT exposed cells to non-ERT exposed cells we also found some differences in the supernatants between molecules involved in mitochrondial dysfunction (12,13-DiHOME) and vasodilation and inflammation $\left(\mathrm{PGE}_{2}\right.$ and $\left.P \mathrm{PG}_{2}\right)$ (51). These findings indicate that various biologically important eicosanoids may mediate ERT effects under both NG and HG conditions in HUVEC cells.

To explore how ERT affected HUVECs on a transcriptional level we performed microarray analysis. We found several transcripts related to endothelial function to be altered when comparing HG to NG incubations including Bmp4, Vegfc and $\mathrm{Ccl} 2$ (table 1). Bmp4 is a member of the bone morphogenetic protein family, which is a part of the TGF $\beta$ superfamily of growth and differentiation factors. In endothelial cells, BMP4 produces a pro-inflammatory gene product inducing icam-1 and monocyte adhesion via NFKB signaling (52). When overexpressed, BMP4 may contribute to endothelial dysfunction, promoting ROS production and apoptosis (53). Vegfc is a PDGF/VEGF family member with roles in angiogenesis and endothelial cell growth. $\mathrm{Ccl} 2$ transcribes a chemotactic factor attracting monocytes 
and basophils. Other transcripts are involved in endothelial aggregation (pear1 (54)) and vasodilation (edn1). Also, HGERT and HG comparisons resulted in altered transcripts linked to endothelial function. These transcripts were involved in apoptosis (bmp6, highly expressed in HUVECs (55)), focal adhesion (jup, foxc1, krit1), differentiation and proliferation (notch1).

Table 1: Altered transcripts with a link to endothelial function.

\begin{tabular}{|c|c|c|c|}
\hline Entrez gene name & Transcript & HGERT/HG & HG/NG \\
\hline Chemokine (C-C motif) ligand 2 & $\mathrm{ccl} 2$ & & 1.04 \\
\hline Endothelin 1 & edn1 & & 0.99 \\
\hline Endoglin & eng & 1.01 & 0.98 \\
\hline Forkhead box C1 & foxc1 & 1.01 & \\
\hline Growth factor receptor-bound protein 10 & grb10 & & 0.99 \\
\hline KRIT1, ankyrin repeat containing & krit1 & 0.99 & \\
\hline Notch 1 & notch1 & 1.02 & \\
\hline Platelet endothelial aggregation receptor 1 & pear1 & & 0.99 \\
\hline Ras homolog gene family, member J & rhoj & 1.02 & \\
\hline $\begin{array}{l}\text { Tumor necrosis factor, alpha-induced protein } 1 \\
\text { (endothelial) }\end{array}$ & tnfaip1 & & 0.99 \\
\hline Vascular endothelial growth factor C & vegfc & & 1.04 \\
\hline Bone morphogenetic protein 4 & bmp4 & & 0.99 \\
\hline Bone morphogenetic protein 6 & bmp6 & 1.01 & \\
\hline
\end{tabular}

Transcripts related to apoptosis are shown in table 2. Under HG, ERT signaled via numerous pro- and anti-apoptotic pathways. As ERT protects endothelial cells from cell death under HG conditions (figure 1A), it seems that ERT has anti-apoptotic effects and that posttranslational modifications of transcribed proteins and dimerization events may explain why pro-apoptotic transcriptomic changes seem to have occurred (Table 2).

Over-represented canonical pathways included (table 3): tricarboxylic acid cycle (TCA) cycle, TGF beta signaling pathway, glutathione metabolism and glucuronidation. Non-canonical networks included PIK3R1, NFKB, HNF, XBP1, SOS, and RELA. These canonical and non-canonical pathways are linked to diabetes onset, insulin signaling and production of adhesion molecules/nitric oxide. Of particular interest are changes in the TCA cycle and electron transport chain, changes of transcripts are shown in table 4. Pyruvate dehydrogenase (PDH) complex transfers the acetyl group of pyruvate to coenzyme A prior to the citric acid cycle. A very slight up regulation with $\mathrm{HG} / \mathrm{NG}$ for pyruvate dehydrogenase (lipoamide) beta (pdhb), encoding the E1 beta subunit responsible for pyruvate dehydrogenase activity was observed. 
Table 2: Altered transcripts with a link to apoptosis.

\begin{tabular}{|c|c|c|c|c|c|c|c|}
\hline \multicolumn{4}{|c|}{ Anti-apoptotic } & \multicolumn{4}{|l|}{ Pro-apoptotic } \\
\hline Pathway & Transcript & HGERT/HG & $\mathrm{HG} / \mathrm{NG}$ & Pathway & Transcript & HGERT/HG & $\mathrm{HG} / \mathrm{NG}$ \\
\hline AKT / Bad & pik3r1 & 1.03 & & Caspase & hip1 & 1.05 & \\
\hline AKT/FRAP1 & ddit4l & 0.97 & & Cell cycle & maged1 & 1.01 & \\
\hline BLK & elf2 & 0.99 & 1.01 & $\begin{array}{l}\text { Cell } \\
\text { cycle/CDK }\end{array}$ & ccni & 1.01 & \\
\hline Caspase & hspe1 & 0.99 & & $\begin{array}{l}\text { Cell } \\
\text { proliferation }\end{array}$ & pdcd7 & 1.02 & 0.99 \\
\hline Caspase & ifi6 & 1.13 & & $\begin{array}{l}\text { Cell } \\
\text { proliferation }\end{array}$ & ubn1 & 1.02 & \\
\hline $\begin{array}{l}\text { Cell } \\
\text { proliferation }\end{array}$ & Furin & 1.02 & & DNA repair & $\mathrm{rrm} 2 \mathrm{~b}$ & 0.98 & \\
\hline DNA repair & actr5 & 1.01 & & FOX & foxn3 & 1.01 & 0.99 \\
\hline FOX & foxc1 & 1.01 & & FOX & foxp1 & 1.01 & \\
\hline $\begin{array}{l}\text { Impedes cyt } \\
\text { c release }\end{array}$ & Gsn & 1.03 & & HER-2/NEU & $\operatorname{casc} 4$ & 0.99 & 1.01 \\
\hline JNK/SAPK & Mbip & 0.98 & & JNK/SAPK & map4k3 & 0.98 & \\
\hline $\begin{array}{l}\text { p38 MAP } \\
\text { kinase }\end{array}$ & stk39 & 0.98 & & JNK/SAPK & sos1 & 1.06 & 0.94 \\
\hline $\begin{array}{l}\text { P53/XIAP } \\
\text { inhibition }\end{array}$ & notch1 & 1.02 & & MYC family & $\mathrm{mxd} 4$ & 1.02 & 0.98 \\
\hline RAS & rsu1 & 0.99 & & P53/CDK & ccnk & 1.01 & \\
\hline RAS & rhob & 1.02 & 0.97 & P53 & rybp & 1.01 & 0.99 \\
\hline RAS & rhoj & 1.02 & & P53 & tp53bp2 & 1.01 & \\
\hline RAS & rab3b & 1.07 & & P53 & tbrg1 & 1.02 & 0.98 \\
\hline TGF $\beta$ & acvr2a & 0.99 & & P53 & tp53i11 & 1.02 & 0.98 \\
\hline \multirow[t]{6}{*}{ TGF $\beta$} & bmp6 & 1.01 & & RAS & rassf2 & 1.01 & 1.03 \\
\hline & eng & 1.01 & 0.98 & WNT & hbp1 & 0.99 & \\
\hline & atxn3 & 0.99 & & & dap & 1.01 & \\
\hline & pdcd6 & 0.99 & & & serinc3 & 1.01 & 0.99 \\
\hline & socs 3 & 1.01 & & & sox4 & 1.01 & 0.99 \\
\hline & txndc5 & 1.03 & & & lyn & 1.02 & 0.99 \\
\hline
\end{tabular}

Branched-chain alpha-keto acid dehydrogenase complex (BCKD), analogous to the $\mathrm{PDH}$ complex, is an inner-mitochondrial enzyme complex responsible for the degradation of branched-chain amino acids (e.g. isoleucine, leucine, and valine). It converts $\alpha$-keto acids to acyl-CoA $+\mathrm{CO}_{2}$ and requires thiamine pyrophosphate (TPP), FAD, NAD ${ }^{+}$, lipoate and coenzyme $A$ as cofactors. BCKD complex contains 24 core transacylase (E2) subunit and associated decarboxylase (E1), dehydrogenase (E3) and regulatory subunits. The lipoamide acyltransferase (or transacylase) E2 subunit component of BCKD is encoded by dihydrolipoamide branched chain transacylase E2 (dbt). DBT was slightly up regulated with HGERT/HG. Succinate CoA synthetase converts succinyl CoA and ADP or GDP to succinate and ATP or GTP. Succinate-CoA ligase, ADP-forming, beta subunit (sucla2) was down regulated with HGERT/HG, and up regulated with HG/NG. Transcripts coding for other subunits such as suclg1 ( $\alpha$ subunit) and suclg2 ( $\beta$ subunit) were not affected by treatments. In the next reaction in the citric acid cycle, succinate dehydrogenase converts 


\section{Chapter 6}

succinate to fumarate in an oxidation step. Succinate dehydrogenase is unique amongst citric acid enzymes, in that it is a nonheme iron protein located in the inner mitochondrial membrane, directly linked to electron transport. Two electrons from $\mathrm{FADH}_{2}$ are transferred to FeS clusters on the enzyme which are in turn transferred to ubiquinone (coenzyme $Q$ ) and then molecular oxygen. Fumurase then converts fumurate to malate, which is in turn oxidized to oxaloacetate by malate dehydrogenase, using the reduction of $\mathrm{NAD}^{+}$to $\mathrm{NADH}$. Ubiquinone binds in a gap between subunits $B, C$, and $D$. Succinate dehydrogenase (sdh) consists of 2 hydrophilic subunits (A, B) and 2 hydrophobic membrane anchor subunits (C, D) with phospholipid binding sites for cardiolipin (CL) and phosphatidylethanolamine (PE). Transcripts coding for the hydrophilic domains (sdha, sdhb) were not affected. Succinate dehydrogenase complex, subunit $C$ and $D$ (sdhc and sdhd) were down regulated with $\mathrm{HGERT/HG}$, and up regulated with $\mathrm{HG} / \mathrm{NG}$.

Table 3: Top 10 pathways regulated by exposure of HUVECs to high glucose (HG effect) or to erythritol during exposure to high glucose (HGERT effect).

\begin{tabular}{ll}
\hline Pathways regulated by exposure to high glucose & Z Score \\
\hline TGF Beta Signaling Pathway & 3.95 \\
\hline Benzo(a)pyrene metabolism & 3.35 \\
\hline Pentose and glucuronate interconversions & 3.26 \\
\hline Glycosylphosphatidylinositol(GPI)-anchor biosynthe & 3.07 \\
\hline Diurnally regulated genes with circadian orthologs & 3.05 \\
\hline Prostate cancer & 2.92 \\
\hline Sphingolipid metabolism & 2.75 \\
\hline Pathways in cancer & 2.58 \\
\hline Antigen processing and presentation & 2.48 \\
\hline Caffeine metabolism & 2.44 \\
\hline Pathways regulated by erythritol during exposure to high glucose & Z Score \\
\hline Chronic myeloid leukemia & 4.03 \\
Citrate cycle (TCA cycle) & 3.88 \\
\hline Delta-Notch Signaling Pathway & 3.78 \\
\hline Prostate cancer & 3.24 \\
\hline Androgen Receptor Signaling Pathway & 3.09 \\
\hline TGF-beta Receptor Signaling Pathway & 2.86 \\
\hline Glutathione metabolism & 2.77 \\
\hline Glucuronidation & 2.61 \\
\hline B cell receptor signaling pathway & 2.48 \\
\hline G13 Signaling Pathway & 2.42 \\
\hline
\end{tabular}


Electron transport occurs in the inner mitochondrial membrane via enzymatic reactions utilizing electron donors and acceptors. It is responsible for generation of ATP from products of the TCA cycle, fatty acid oxidation and amino acid oxidation. This pathway is tied to oxidative stress (and hyperglycemia via excess glucose equivalents entering the mitochondrial machinery) as a small percentage of electrons 'leak out' resulting in superoxide formation. Numerous transcripts involved in electron transport (11) had slight down regulation with HGERT/HG, five of these were oppositely regulated with HG/NG (Table 2). Transcripts were changed in all 5 electron transport chain complexes. In complex I, NADH dehydrogenase, the subunits ubiquinone 1 alpha, subcomplexes- 4 (ndufa4) and 12 (ndufa12) were down regulated with HGERT/HG. Ndufa4 was up regulated with HG/NG. Overactivity of the mitochondrial respiratory chains occurs during hyperglycemia (56), increasing transcription of complex II. This in turn increases electron leaking and production of superoxide radicals. Subunits C and D of complex II were down regulated with HGERT/HG, and up regulated with HG/NG (see also citric acid cycle). This countering of up regulation by ERT under HG conditions probably reduces superoxide production. The ability of ERT to prevent HG-induced increases in SDH suggests ERT may protect the mitochondria from oxidative damage via this mechanism. The reduction of coenzyme $Q$ in complex III (cytochrome $\mathrm{bc}_{1}$ complex) can also contribute to oxidant production as highly reactive ubisemiquinone free radicals are formed as intermediaries in the $Q$ cycle, leading to electron leakage and superoxide radicals (57). In complex III, Ubiquinolcytochrome $c$ reductase binding protein (uqcrb=qcr7; orthology to subunit 7) and ubiquinol-cytochrome $c$ reductase, complex III subunit $X$ (ucrc=uqcr10=qcr9) were down regulated with HGERT/HG. uqcrb was up regulated with HG/NG. In complex IV, cytochrome c oxidase (COX), subunits VB- (cox5b), VIla- (cox7a2), VIIIA- (cox8a), and 16 (cox16) were down regulated with HGERT/HG (and not affected with $\mathrm{HG} / \mathrm{NG}$ ). COX assembly mitochondrial protein homolog (S. cerevisiae) (cmc1) is required for mitochondrial COX assembly and respiration. It binds copper, and may be involved in copper trafficking and distribution to COX and superoxide dismutase 1 (SOD1) (58). Cmc1 showed slight up regulation with HG/NG (not changed with HGERT/HG). In complex $\mathrm{V}$, ATP synthase, $\mathrm{H}^{+}$transporting, mitochondrial $\mathrm{F}_{1}$ complex, subunits- epsilon (atp5e) and 0 (atp5o) convert ADP to ATP, pumping protons across the proton-motive force. $F_{1}$ complexes (and their 5 subunits) contain extra-membranous catalytic activity. $F_{0}$ complexes contain the membranespanning component comprising the proton channel, and contain 9 subunits. Atp5e was down regulated with $\mathrm{HGERT/HG}$, and up regulated with $\mathrm{HG} / \mathrm{NG}$; atp5o was very slightly down regulated with HGERT/HG. ATP synthase, $\mathrm{H}^{+}$transporting, mitochondrial $F_{0}$ complex, subunit $G$ (atp5I) was slightly up regulated with $\mathrm{HG} / \mathrm{NG}$ 
only.

Table 4: Transcripts changed in citric acid cycle and electron transport system.

\begin{tabular}{llll}
\hline Complex & Transcript & HGERT/HG & HG/NG \\
\hline Pyruvate dehydrogenase & Pdhb & & 1.01 \\
Succinate CoA synthetase & sucla2 & 0.99 & 1.01 \\
Succinate dehydrogenase & Sdhc & 0.96 & 1.02 \\
\hline Complex I NADH dehydrogenase & Sdhd & 0.98 & 1.01 \\
& ndufa4 & 0.99 & 1.02 \\
\hline Complex II Succinate dehydrogenase & ndufa12 & 0.99 & \\
& Sdhc & 0.96 & 1.02 \\
Complex III Cytochrome bc1 & Sdhd & 0.98 & 1.01 \\
& qcr7 (uqcrb) & 0.99 & 1.01 \\
\hline Complex IV cytochrome c oxidase & qcr9 (ucrc, uqcr10) & 0.99 & \\
& cox5b & 0.98 & \\
& cox7a2 & 0.99 & \\
& cox8a & 0.99 & \\
\hline Complex V ATP synthase & cox16 & 0.99 & \\
\hline & cmc1 & & 1.01 \\
& atp5e & 0.99 & 1.01 \\
\hline & atp5o & 0.99 & \\
\hline
\end{tabular}

Although there were considerable changes to electron transport transcripts, there was limited evidence from transcriptomic and targeted analyses that ERT acts like "classical" antioxidant in decreasing levels of oxidants via effects on glutathione peroxidases (gpx), peroxiredoxins (prdx), superoxide dismutases (sod), superoxides (alox, cyb, duox, ncf, nos), ROS metabolism and oxidative stress responsive genes. Based on transcript annotations, some transcripts are associated with ROS, including krit1, bmp4 and sh3pxd2b (increased), the latter with a role in NOXdependent ROS production. Also, transcriptomic changes related to the citric acid cycle and electron transport chain suggest ERT may reduce mitochondrial superoxide production through a novel mechanism.

This study shows that erythritol has a large number of minor, often not reaching significance, beneficial effects in endothelial cells during exposure to high glucose. It is difficult to pinpoint a specific effect by which erythritol protects the cells during diabetic stress, and thus to explain why erythritol was capable of preventing the onset of endothelial dysfunction in the diabetic rat. However, it is more than likely, that the combination of all the effects displayed by erythritol is ultimately responsible for its extraordinary protective effect in vivo. 
In conclusion, our present data point at a therapeutically important protective effect of ERT in endothelial cells. Overall, this study demonstrates that ERT by itself (i.e. under non-diabetic conditions) has minimal effects on HUVECs. Viability, oxidative damage, endothelial function parameters and the transcriptome do not show changes after incubation with ERT. However, when cells are exposed to HG following preincubation with ERT, a number of deleterious effects caused by HG are reversed. The observation that ERT does not affect single endpoints but has multi-targeted effects is not unusual for a natural compound. We have previously observed the same mode of action in other studies (59). Therefore, it is expected that in non-diabetic subjects ERT will not affect the endothelium which is a desirable property, while in diabetic subjects where the endothelium is under diabetic stress, ERT could shift a variety of damage and dysfunction parameters to a safer side. ERT can therefore be regarded as a compound that has definite endothelium protective effects during hyperglycemia.

There is still a considerable need for safe agents that can reduce the risk of developing diabetic complications. These diabetic complications in general are the consequence of endothelium dysfunction. ERT can therefore be of great importance to a rapidly growing population of people with diabetes to reduce their risk of developing diabetic complications.

Because diabetes is a chronic disease, supplementation with antioxidants to prevent the onset and development of diabetic complications will be chronic as well. Compounds with strong and explicit biological activities are probably not indicated in long term protection during diabetes. It is therefore important to choose a compound that has mild protective effects in small vessel and arteries because the endothelial cells are an important target of hyperglycemic damage. This study shows that ERT exerts many such beneficial effects on endothelial cells during exposure to diabetic stressors.

\section{Acknowledgements}

We thank Christophe Morisseau, Department of Entomology and U.C. Davis Cancer Center, University of California Davis, CA for technical assistance in measuring eicosanoids and oxylipins in HUVEC cells. We also thank the Bioinformatics Maastricht (BigCAT) department members: Chris Evelo, Magali Jaillard, and Lars Eijssen. 


\section{References}

1. Brownlee M: Biochemistry and molecular cell biology of diabetic complications. Nature 2001;414:813-820

2. Ramasamy R, Fang Yan S, Schmidt AM: The RAGE axis and endothelial dysfunction: Maladaptive roles in the diabetic vasculature and beyond. Trends in Cardiovascular Medicine 2005;15:237-243

3. Furchgott RF, Jothianandan D: Endothelium-Dependent and -Independent Vasodilation Involving Cyclic GMP: Relaxation Induced by Nitric Oxide, Carbon Monoxide and Light. J Vasc Res 1991;28:52-61

4. Grieve DJ, Avella MA, Botham KM, Elliott J: Effects of chylomicrons remnants on endothelium-dependent relaxation of rat aorta. Eur J Pharmacol 1998;348:181-190

5. Praticò D: Antioxidants and endothelium protection. Atherosclerosis 2005;181:215-224

6. Ceriello A: New insights on oxidative stress and diabetic complications may lead to a "causal" antioxidant therapy. Diabetes Care 2003;26:1589-1596

7. Bernt WO, Borzelleca JF, Flamm G, Munro IC: Erythritol: a review of biological and toxicological studies. Regulatory Toxicology and Pharmacology 1996;24:S191-S197

8. Yokozawa T, Kim HY, Cho EJ: Erythritol attenuates the diabetic oxidative stress through glucose metabolism and lipid peroxidation in streptozotocin-induced diabetic rats. Journal of Agricultural and Food Chemistry 2002;50:5485-5489

9. Munro IC, Berndt WO, Borzelleca JF, Flamm G, Lynch BS, Kennepohl E, Bar EA, Modderman J, Bernt WO: Erythritol: an interpretive summary of biochemical, metabolic, toxicological and clinical data. Food Chem Toxicol 1998;36:1139-1174

10. Noda K, Nakayama K, Oku T: Serum glucose and insulin levels and erythritol balance after oral administration of erythritol in healthy subjects. European Journal of Clinical Nutrition 1994;48:286-292

11. den Hartog GJ, Boots AW, Adam-Perrot A, Brouns F, Verkooijen IW, Weseler AR, Haenen GR, Bast A: Erythritol is a sweet antioxidant. Nutrition 2010;26:449-458

12. den Hartog GJM, Boots AW, Haenen GRMM, van der Vijgh WJF, Bast A: Lack of inhibition of endothelial nitric oxide synthase in the isolated rat aorta by doxorubicin. Toxicol In Vitro 2003;17:165-167

13. Paquay JBG, $t$ Hoen PAC, Voss $H-P$, Bast $A$, Timmerman $H$, Haenen GRMM: Nitric oxide synthase inhibition by dimaprit and dimaprit analogues. Br J Pharmacol 1999;127:331-334

14. Ulker S, McKeown PP, Bayraktutan U: Vitamins reverse endothelial dysfunction through regulation of eNOS and NAD(P)H oxidase activities. Hypertension 2003;41:534-539

15. Räthel TR, Leikert J, Vollmar AM, Dirsch VM: Application of 4,5-diaminofluorescein to reliably measure nitric oxide released from endothelial cells in vitro. Biol Proc Online 2003;5:136-142

16. Liu JY, Li N, Yang J, Li N, Qiu H, Ai D, Chiamvimonvat N, Zhu Y, Hammock BD: Metabolic profiling of murine plasma reveals an unexpected biomarker in rofecoxib-mediated cardiovascular events. Proceedings of the National Academy of Sciences of the United States of America 2010;107:17017-17022

17. Yang J, Schmelzer K, Georgi K, Hammock BD: Quantitative profiling method for oxylipin metabolome by liquid chromatography electrospray ionization tandem mass spectrometry. Analytical Chemistry 2009;81:8085-8093

18. Lundström S, Yang J, Källberg HJ, Thunberg S, Gafvelin G, Haeggström JZ, Grönneberg R, Grunewald J, van Hage M, Hammock BD, Eklund A, Wheelock AM, Wheelock CE: Allergic asthmatics show divergent lipid mediator profiles from healthy controls both at baseline and following birch pollen provocation. PLoS One 2012; 7:e33780

19. Team RDC: $R$ : A language and environment for statistical computing. Vienna, Austria, $R$ Foundation for Statistical Computing, 2003 
20. Gautier L, Cope L, Bolstad BM, Irizarry RA: affy--analysis of Affymetrix GeneChip data at the probe level. Bioinformatics 2004;20:307-315

21. Gentleman RC, Carey VJ, Bates DM, Bolstad B, Dettling M, Dudoit S, Ellis B, Gautier L, Ge Y, Gentry J, Hornik K, Hothorn T, Huber W, lacus S, Irizarry R, Leisch F, Li C, Maechler M, Rossini AJ, Sawitzki G, Smith C, Smyth G, Tierney L, Yang JY, Zhang J: Bioconductor: open software development for computational biology and bioinformatics. Genome Biol 2004;5:R80

22. Dai M, Wang P, Boyd AD, Kostov G, Athey B, Jones EG, Bunney WE, Myers RM, Speed TP, Akil $\mathrm{H}$, Watson SJ, Meng F: Evolving gene/transcript definitions significantly alter the interpretation of GeneChip data. Nucleic Acids Res 2005;33:e175

23. Irizarry RA, Hobbs B, Collin F, Beazer-Barclay YD, Antonellis KJ, Scherf U, Speed TP: Exploration, normalization, and summaries of high density oligonucleotide array probe level data. Biostatistics 2003;4:249-264

24. Gentleman R, Carey V, Huber W, Irizarry R, Dudoit S: Linear models for microarray data In: Bioinformatics and Computational Biology Solutions Using $R$ and Bioconductor (Statistics for Biology and Health). . Springer, 2005

25. van lersel MP, Kelder T, Pico AR, Hanspers K, Coort S, Conklin BR, Evelo C: Presenting and exploring biological pathways with PathVisio. BMC Bioinformatics 2008;9:399

26. Moncada S, Palmer RM, Higgs EA: Nitric oxide: physiology, pathophysiology, and pharmacology. Pharmacol Rev 1991;43:109-142

27. Seol GH, Ahn SC, Kim JA, Nilius B, Suh SH: Inhibition of endothelium-dependent vasorelaxation by extracellular $\mathrm{K}(+)$ : a novel controlling signal for vascular contractility. Am J Physiol Cell Physiol 2004;286:H329-H339

28. Pakala R, Benedict CR: Endothelial cells regulate the proliferation of monocytes in vitro. Atherosclerosis 1999;147:25-32

29. Pendurthi UR, Williams JT, Rao LVM: Acidic and basic fibroblast growth factors suppress transcriptional activation of tissue factor and other inflammatory genes in endothelial cells. Arterioscler Thromb Vasc Biol 1997;17:940-946

30. Wadham C, Parker A, Wang L, Xia P: High glucose attenuates protein S-nitrosylation in endothelial cells: role of oxidative stress. Diabetes 2007;56:2715-2721

31. Kageyama S, Yokoo H, Tomita K, Kageyama-Yahara N, Uchimido R, Matsuda N, Yamamoto S, Hattori Y: High glucose-induced apoptosis in human coronary artery endothelial cells involves up-regulation of death receptors. Cardiovasc Diabetol 2011;10:73

32. Risso A, Mercuri F, Quagliaro L, Damante G, Ceriello A: Intermittent high glucose enhances apoptosis in human umbilical vein endothelial cells in culture. Am J Physiol Endocrinol Metab 2001;281:E924-E930

33. Tsuneki H, Sekizaki N, Suzuki T, Kobayashi S, Wada T, Okamoto T, Kimura I, Sasaoka T: Coenzyme Q10 prevents high glucose-induced oxidative stress in human umbilical vein endothelial cells. European Journal of Pharmacology 2007;566:1-10

34. Koshimura K, Tanaka J, Murakami Y, Kato Y: Involvement of nitric oxide in glucose toxicity on differentiated PC12 cells: prevention of glucose toxicity by tetrahydrobiopterin, a cofactor for nitric oxide synthase. Neuroscience Research 2002;43:31-38

35. Chakrabarti S, Cheung CC, Davidge ST: Estradiol attenuates high glucose-induced endothelial nitrotyrosine: role for neuronal nitric oxide synthase. Am J Physiol Cell Physiol 2012;302:C666-675

36. Zou MH, Shi C, Cohen RA: High glucose via peroxynitrite causes tyrosine nitration and inactivation of prostacyclin synthase that is associated with thromboxane/prostaglandin $\mathrm{H}(2)$ receptor-mediated apoptosis and adhesion molecule expression in cultured human aortic endothelial cells. Diabetes 2002;51:198-203

37. Huie RE, Padmaja S: The reaction of NO with superoxide. Free Radic Res Commun 


\section{3;18:195-199}

38. Channon KM, Guzik TJ: Mechanisms of superoxide production in human blood vessels: relationship to endothelial dysfunction, clinical and genetic risk factors. J Physiol Pharmacol 2002;53:515-524

39. Pandolfi A, Di Pietro N: High glucose, nitric oxide, and adenosine: a vicious circle in chronic hyperglycaemia? Cardiovasc Res 2010;86:9-11

40. Wattanapitayakul SK, Bauer JA: Oxidative pathways in cardiovascular disease. Roles, mechanisms, and therapeutic implications. Pharmacol Ther 2001;89:187-206

41. Hippeli S, Rohnert U, Koske D, Elstner EF: OH-radical-type reactive oxygen species derived from superoxide and nitric oxide: a sensitive method for their determination and differentiation. Z Naturforsch C 1997;52:564-570

42. Li J, Wang JJ, Zhang SX: Preconditioning with endoplasmic reticulum stress mitigates retinal endothelial inflammation via activation of X-box binding protein 1 . Journal of Biological Chemistry 2011;286:4912-4921

43. Nishikawa T, Edelstein D, Du XL, Yamagishi S-i, Matsumura T, Kaneda Y, Yorek MA, Beebe D, Oates PJ, Hammes H-P, Giardino I, Brownlee M: Normalizing mitochondrial superoxide production blocks three pathways of hyperglycaemic damage. Nature 2000;404:787-790

44. Ding $\mathrm{H}$, Aljofan M, Triggle CR: Oxidative stress and increased eNOS and NADPH oxidase expression in mouse microvessel endothelial cells. Journal of Cellular Physiology 2007;212:682-689

45. Dobrian AD, Lieb DC, Cole BK, Taylor-Fishwick DA, Chakrabarti SK, Nadler JL: Functional and pathological roles of the 12- and 15-lipoxygenases. Progress in Lipid Research 2011;50:115-131

46. Natarajan R, Gerrity RG, Gu JL, Lanting L, Thomas L, Nadler JL: Role of 12-lipoxygenase and oxidant stress in hyperglycaemia-induced acceleration of atherosclerosis in a diabetic pig model. Diabetologia 2002;45:125-133

47. Hedrick CC, Kim MD, Natarajan RD, Nadler JL: 12-Lipoxygenase products increase monocyte:endothelial interactions. Advances in Experimental Medicine and Biology 1999;469:455-460

48. Tang DG, Diglio CA, Bazaz R, Honn KV: Transcriptional activation of endothelial cell integrin alpha $v$ by protein kinase C activator 12(S)-HETE. Journal of Cell Science 1995;108 ( Pt 7):2629-2644

49. Simionescu N: Prelesional changes of arterial endothelium in hyperlipoproteinemic atherogenesis. In Endothelial Cell Biology in Health and Disease Simionescu N, Simionescu M, Eds. New York, Plenum Press, 1988, p. 385-429

50. Oguro A, Fujita N, Imaoka S: Regulation of soluble epoxide hydrolase (sEH) in mice with diabetes: high glucose suppresses sEH expression. Drug Metab Pharmacokinet 2009;24:438445

51. Moran JH, Nowak G, Grant DF: Analysis of the toxic effects of linoleic acid, 12,13-cisepoxyoctadecenoic acid, and 12,13-dihydroxyoctadecenoic acid in rabbit renal cortical mitochondria. Toxicology and Applied Pharmacology 2001;172:150-161

52. Sorescu GP, Sykes M, Weiss D, Platt MO, Saha A, Hwang J, Boyd N, Boo YC, Vega JD, Taylor WR, Jo $\mathrm{H}$ : Bone morphogenic protein 4 produced in endothelial cells by oscillatory shear stress stimulates an inflammatory response. Journal of Biological Chemistry 2003;278:31128-31135

53. Bhasin M, Yuan L, Keskin DB, Otu HH, Libermann TA, Oettgen P: Bioinformatic identification and characterization of human endothelial cell-restricted genes. BMC Genomics 2010;11:342

54. Nanda N, Bao M, Lin H, Clauser K, Komuves L, Quertermous T, Conley PB, Phillips DR, Hart MJ: Platelet endothelial aggregation receptor 1 (PEAR1), a novel epidermal growth 
factor repeat-containing transmembrane receptor, participates in platelet contact-induced activation. Journal of Biological Chemistry 2005;280:24680-24689

55. Su Al, Cooke MP, Ching KA, Hakak Y, Walker JR, Wiltshire T, Orth AP, Vega RG, Sapinoso LM, Moqrich A, Patapoutian A, Hampton GM, Schultz PG, Hogenesch JB: Large-scale analysis of the human and mouse transcriptomes. Proceedings of the National Academy of Sciences of the United States of America 2002;99:4465-4470

56. Chen J, Li Y, Lavigne JA, Trush MA, Yager JD: Increased mitochondrial superoxide production in rat liver mitochondria, rat hepatocytes, and HepG2 cells following ethinyl estradiol treatment. Toxicol Sci 1999;51:224-235

57. Finkel T, Holbrook NJ: Oxidants, oxidative stress and the biology of ageing. Nature 2000;408:239-247

58. Horn D, Al-Ali H, Barrientos A: Cmc1p is a conserved mitochondrial twin CX9C protein involved in cytochrome $\mathrm{c}$ oxidase biogenesis. Mol Cell Biol 2008;28:4354-4364

59. Weseler AR, Ruijters EJB, Drittij-Reijnders M-J, Reesink KD, Haenen GRMM, Bast A: Pleiotropic Benefit of Monomeric and Oligomeric Flavanols on Vascular Health - A Randomized Controlled Clinical Pilot Study. PLoS One 2011;6:e28460 


\section{Chapter 7}

\section{Potential anti-angiogenic effects of erythritol}

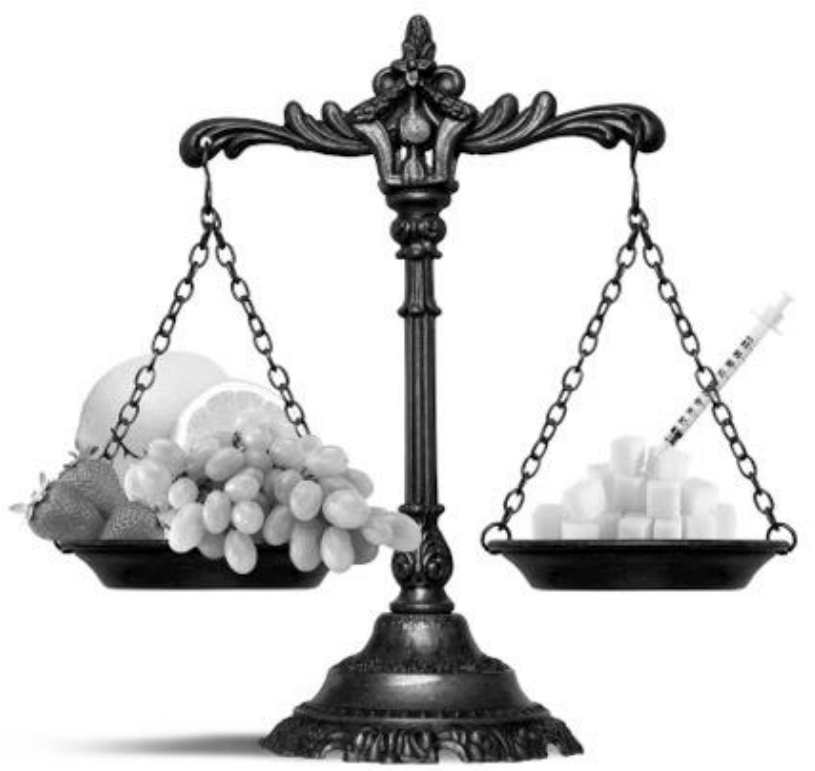

Daniëlle M.P.H.J. Boesten

Gertjan J.M. den Hartog

Peter de Cock

Douwina Bosscher

Aalt Bast 


\begin{abstract}
Angiogenesis, the formation of new blood vessels from pre-existing vessels, requires a strict balance between pro-angiogenic and anti-angiogenic factors. When the balance is disturbed, excessive angiogenesis can occur, a condition which has been associated with many diseases including diabetes. In this study we extended our previous studies on the endothelial protective diabetic-safe sweetener erythritol, to determine the influence of erythritol on high glucose induced angiogenesis. We used an endothelial cell model, exposed to normal and high glucose concentrations, in the presence or absence of erythritol. We examined secretion and expression of angiogenic factors and we determined the ability of the endothelial cells to form three-dimensional structures with a tube formation assay. We found that incubation with high glucose mainly induced expression and release of pro-angiogenic factors and it increased the rate of tube formation. Erythritol inhibited tube formation and decreased the expression of anti-angiogenic factors. Therefore erythritol could be of interest as a preventive and/or therapeutic target in the pathology of diabetic complications like diabetic retinopathy and diabetic nephropathy.
\end{abstract}




\section{Introduction}

Angiogenesis is the the formation of new blood vessels from pre-existing vessels. It is a tightly controlled process in growth and development. However, in many diseases the body loses the control over angiogenesis, which can result in excessive or insufficient growth of new blood vessels. Excessive angiogenesis has been associated with many diseases including cancer, rheumatoid arthritis, psoriasis and diabetes (1).

Diabetes is characterized by conditions such as chronic inflammation and oxidative stress which can stimulate angiogenesis, ultimately contributing to the pathology of micro- and macrovascular complications (2). For example, increased levels of vascular endothelial growth factor A (VEGFa) is a major cause of irreversible vision loss in diabetic retinopathy (3). Abnormal angiogenesis also play a role in diabetic nephropathy. High levels of transforming growth factor- $\beta$ (TGF- $\beta$ ) and VEGFa lead to glomular hypertrophy, which in turn increases vascular permeability and cause extravasations of plasma proteins (4). Inhibition of pathological angiogenesis may benefit patients with these complications.

Compounds to treat pathological angiogenesis should be selective (i.e. only effective against newly forming vessels), non-toxic and reversible when angiogenesis is needed (e.g. during wound healing). Research has shown that naturally occurring bioactive compounds like phenolics, carbohydrates, vitamins, lipids, peptides and proteins show anti-angiogenic capacity mainly by inhibiting enzymes involved in the process of angiogenesis (5). In previous studies we found that the natural diabetic-safe sweetener erythritol protected endothelial cells during exposure to high concentrations of glucose in vitro and prevented loss of endothelium dependent vasorelaxation in streptozotocin diabetic rats $(6 ; 7)$. Extending these studies, we investigated the potential of erythritol to protect against high glucose induced angiogenesis.

\section{Material and methods}

\section{Chemicals}

All chemicals were purchased from Sigma-Aldrich (Steinheim, Germany) unless stated otherwise. F12K medium, Hank's Balanced Salt Solution (HBSS), trypsinEDTA, non-heat inactivated fetal calf serum (FCS), and penicillin/streptomycin were obtained from Gibco (Breda, The Netherlands). Endothelial cell growth supplement (ECGS) was obtained from BD Bioscience (Breda, The Netherlands). Heparin was purchased from Leo Pharmaceuticals (Amsterdam, The Netherlands). 


\section{Cell culture}

Human umbilical vein endothelial (HUVEC) cell line CRL-1730 was obtained from ATCC. HUVECs were cultured in F12K medium with $10 \%$ non-heat inactivated FCS, $1 \%$ penicillin/streptomycin, $0.05 \mathrm{mg} / \mathrm{ml}$ ECGS and $0,1 \mathrm{mg} / \mathrm{ml}$ heparin. Cells were maintained in collagen coated T75 flasks (Greiner Bio-one, Alphen a/d Rijn, The Netherlands) at $37^{\circ} \mathrm{C}$ in a $5 \% \mathrm{CO} 2$ atmosphere. For experiments, cells were seeded in 6 well plates / T75 flasks and grown until 80\% confluency. Next, medium was removed and cells were washed with HBSS. New medium and erythritol (final concentration $5 \mathrm{mM}$ ) or vehicle solution (medium) was added to the cells. After 1 hour incubation glucose (final concentration $30 \mathrm{mM}$ glucose) or vehicle (medium) was added to the cells. Subsequently, cells were incubated for 24 hours.

\section{Gene expression analysis}

RNA was isolated from Qiazol suspended cells according to manufacturer's protocol and quantified spectrophotometrically with a Nanodrop. Reverse transcriptase reaction was performed using 500 ng of RNA, which was reverse transcribed into CDNA using iScript ${ }^{\mathrm{TM}}$ cDNA synthesis kit (Biorad). Next, real time PCR was performed with a Biorad MylQ iCycler Single Color RT-PCR detection system using Sensimix ${ }^{\mathrm{TM}}$ Plus SYBR and Fluorescein (Quantace-Bioline, Alphen a/d Rijn, The Netherlands), $5 \mu$ l diluted (10x) cDNA and $0.3 \mu \mathrm{M}$ primers in a total volume of 25 $\mu \mathrm{l}$. PCR was conducted as follows: denaturation at $95^{\circ} \mathrm{C}$ for 10 minutes, followed by 40 cycles of $95^{\circ} \mathrm{C}$ for 15 seconds and $60^{\circ} \mathrm{C}$ for 45 seconds. After PCR, a melt curve $\left(60-95^{\circ} \mathrm{C}\right)$ was produced for product identification and purity. $\beta$-actin was included as internal control. Primer sequences are shown in table 1 . Data were analysed using the MylQ software system (BioRad) and were expressed as relative gene expression (fold change) using the $2^{\Delta \Delta C t}$ method.

Table 1: Primer sequences for genes used for gene expression analysis

\begin{tabular}{lll}
\hline Gene & Forward (5' to $\mathbf{3}^{\prime}$ ) & Reverse (5' to $\mathbf{3}^{\prime}$ ) \\
\hline Beta-actin ( $\boldsymbol{\beta}$-actin) & CCTGGCACCCAGCACAAT & GCCGATCCACACGGAGTACT \\
TIMP2 & TCCTCTTGATAGGGTTGCCA & CGTTTTGCAATGCAGATGTA \\
TIMP3 & ATGGTGTAGACCAGCGTGC & AGGACGCCTTCTGCAACTC \\
VEGFA & AGCTGCGCTGATAGACATCC & CTACCTCCACCATGCCAAGT \\
VEGFC & TGGACACAGACCGTAACTGC & CGGACTCGACCTCTCGG \\
ANG2 & GCCACTGAGTGTTGTTTTCC & CCTACGTGTCCAATGCTGTG \\
MMP2 & GGAAAGCCAGGATCCATTTT & ATGCCGCCTTTAACTGGAG \\
\hline
\end{tabular}




\section{Measurement of MCP-1, IL-6 and IL-8}

Culture medium was collected after incubation. Monocyte chemoattractant protein-1 (MCP-1), interleukin-6 (IL-6) and interleukin-8 (IL-8) in the supernatant of the cells were measured using the Bio-plex pro assay according to manufacturer's instructions. This assay uses antibodies coupled to magnetic beads which react with $50 \mu \mathrm{l}$ supernatant. After a series of washes to remove unbound protein, a biotinylated detection antibody specific for MCP-1, IL-6 or IL-8 was added to the reaction. After 30 minutes incubation and several washes, a streptavidinphycoerythrin (streptavidin-PE) reporter complex was added to bind biotinylated detection antibodies. The plate was then read using the Luminex system and data was analyzed using the Bio-Plex Manager software ${ }^{\mathrm{TM}}$.

\section{Tube formation assay}

The assay was performed with the Cultrex In Vitro Angiogenesis Assay Kit Tube Formation (Amsbio, Abingdon, UK). In short, we exposed HUVECs to normal (7 mM) or high ( $30 \mathrm{mM}$ ) glucose for 24 hours in the presence or absence of ERT. After 23 hour incubation, $50 \mu \mathrm{l}$ BME solution was added per well of a 96 well plate. The plate was incubated for 60 minutes at $37^{\circ} \mathrm{C}$ to allow gelatinization. Next, exposed cells were added to the well (concentration of $3 * 10^{4}$ cells). Tube formation was monitored by an inverted phase contrast microscope and pictures were taken by an attached digital output Olympus camera.

\section{Statistical analysis}

The effect of HG incubation and effects of erythritol were tested using Student's ttest for independent samples or the Mann-Whitney $U$ test when not normally distributed. P-values $<0.05$ were considered statistically significant and $p$-values $<0.1$ were considered statistical trends. Statistical analyses were analyzed with SPSS for Windows (version 20.0; SPSS Inc., Chicago, IL, USA).

\section{Results}

After exposure of HUVECs to normal and high glucose concentrations for 24 hours, angiogenic factors in the culture medium were measured (figure 1). No effects on IL-6 concentrations were observed. Incubation with erythritol (under normal glucose conditions) and with high glucose showed an increase in IL-8 levels in the culture medium. The same effect was seen on MCP-1 levels, although here the increase due to incubation with high glucose was much higher (more than 10 times). Pre/co incubation with erythritol did not reduce the increases in IL-8 and MCP-1 caused by high glucose. 

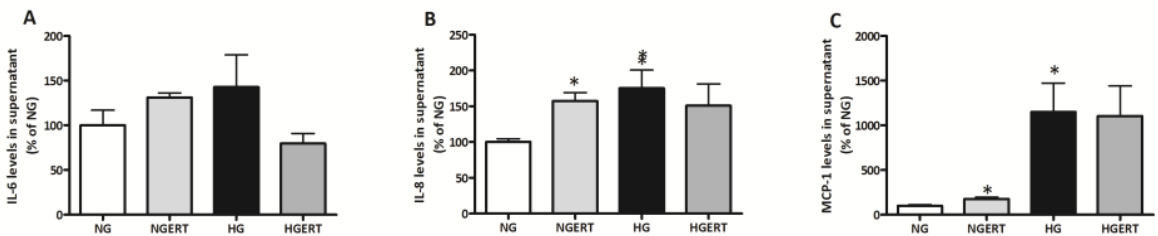

Figure 1: Effect on cytokine levels in the supernatant of HUVECs pre/co incubated with $5 \mathrm{mM}$ erythritol (ERT) in normal glucose (NG, $7 \mathrm{mM}$ ) or high glucose (HG, $30 \mathrm{mM}$ ) for 24 hours on levels of interleukin-6 (IL-6; A), interleukin-8 (IL-8; B) and monocyte chemotactic protein-1 (MCP-1; C). Data are expressed as mean \pm standard error of the mean (SEM) of at least three experiments. ${ }^{*}=p<0.05$ compared to NG.

The gene expression of several angiogenic factors was also measured (figure 2). No effects were observed on the expression of angiopoietin2 (ANG2), matrix metalloproteinase 2 (MMP2), and vascular endothelial growth factor A (VEGFa). High glucose incubation increased the expression of VEGFC and showed a trend towards decreased expression of tissue inhibitor of metalloproteinases 3 (TIMP3). Pre/co incubation with erythritol showed a trend toward a lower expression of TIMP2, while it increased the expression of TIMP3 compared to high glucose incubation alone.

A

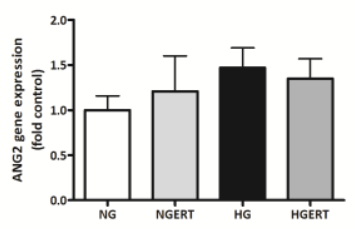

D

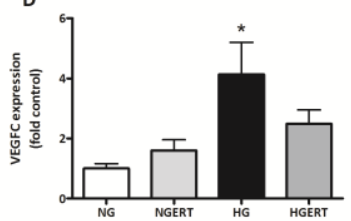

B
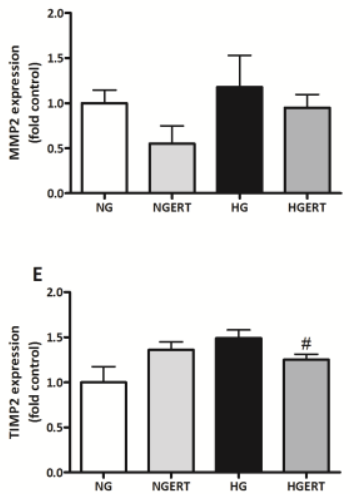

C
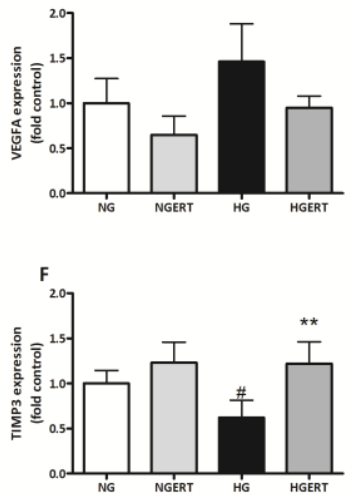

Figure 2: Effect of pre/co incubation with $5 \mathrm{mM}$ erythritol (ERT) on HUVECS cultured in normal glucose (NG, $7 \mathrm{mM}$ ) or high glucose (HG, $30 \mathrm{mM}$ ) for 24 hours on gene expression of angiopoietin2 (ANG2, A), matrix metalloproteinase 2 (MMP2, B), vascular endothelial growth factor A (VEGFA, C), vascular endothelial growth factor C (VEGFC, D), tissue inhibitor of metalloproteinases 2 (TIMP2, E) and tissue inhibitor of metalloproteinases 3 (TIMP3, F). Data are expressed as mean \pm standard error of the mean (SEM) of at least three experiments. ${ }^{*}=$ p $<0.05$ compared to NG; ${ }^{* *}=p<0.05$ compared to HG; \# = p<0.1 compared to HG. 
The effect of erythritol on angiogenesis was determined using an assay to measure the ability of endothelial cells to form three-dimensional structures, the tube formation assay. Cells incubated with high glucose before being put on gel showed a faster formation of the tubular network. After 4 hours a network is visible in the high glucose group, while the other conditions are still in a preliminary stage. After 6 hours, the other conditions also show tube formation, but less pronounced than cells incubated with high glucose (figure 3 ).

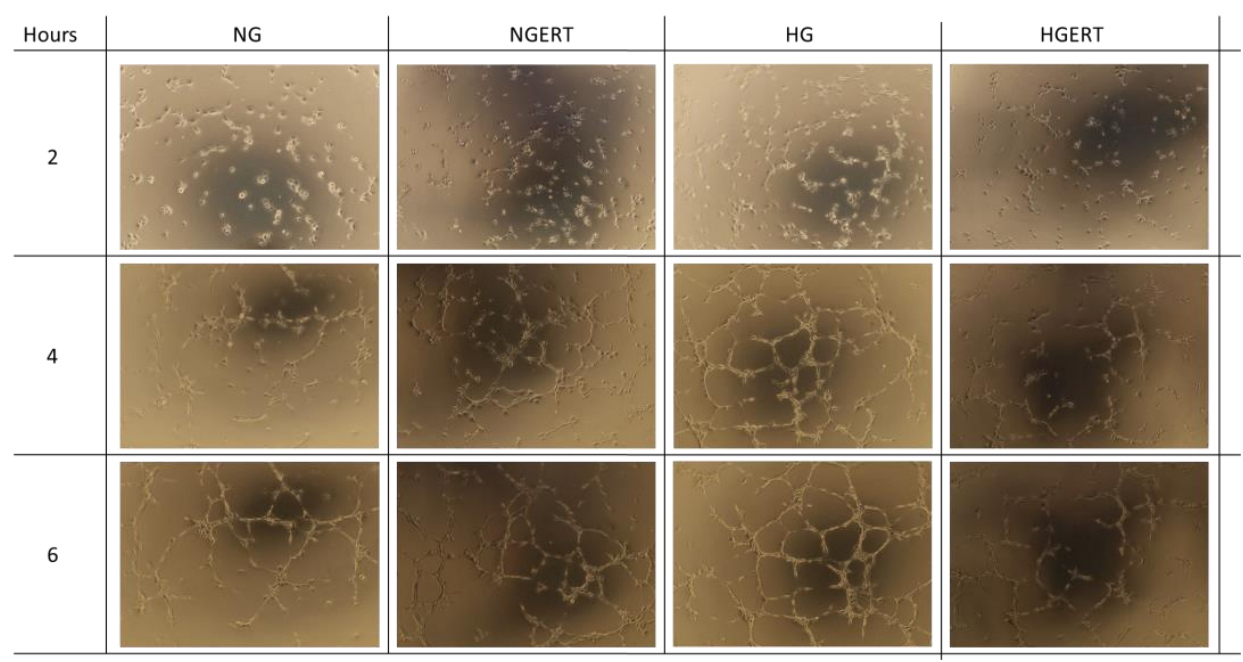

Figure 3: HUVECS were pre/co incubated with $5 \mathrm{mM}$ erythritol (ERT) in cultured in normal glucose (NG, $7 \mathrm{mM}$ ) or high glucose (HG, $30 \mathrm{mM}$ ) for 24 hours after which cells were put on gelled BME to assess the effects on tube formation. Numbers on the left represent hours after cells were put on gelled BME.

\section{Discussion}

In this study we measured the effect of high glucose incubation on several steps of the angiogenic process. The angiogenic process consists of multiple steps and requires a balanced equilibrium between pro-angiogenic and anti-angiogenic factors (figure 4). First endothelial cell activation by angiogenic factors (e.g. VEGF) takes place. Activated endothelial cells secrete proteases (e.g. MMPs) which are capable to degrade the capillary basement membrane. Together with the proteases their inhibitors (e.g. TIMPs) are excreted to ensure local proteolytic activity. After membrane degradation, the endothelial cells migrate to angiogenic stimuli (e.g. released from wound-associated macrophages). Endothelial cell proliferation also occurs during this part of the process, which is mediated by cell adhesion 
molecules. Subsequently, the new outgrowth of endothelial cells needs to reorganize into a three-dimensionally tubular structure. The endothelial cells will form a lumen and then pericytes and smooth muscle cells are recruited which are required for further stabilization (8).

An increase of IL-8 release in the culture medium was observed. This is in line with findings in the literature that culturing endothelial cells in high glucose stimulates IL-8 production (9). IL-8 is known to be a potent promoter of angiogenesis. Biological effects of IL-8 on endothelial cells are concentration dependent, the chemotactic properties of IL-8 are lower at higher concentrations (10). Also MCP-1 was highly induced by high glucose incubation. Stimulation of this chemokine by high glucose is in line with findings in different cell and animal models. (11-13). MCP-1 is also known to increase angiogenesis, through directly acting on endothelial cells but also via monocyte/macrophage recruitment and vessel formation (14). Pre/co incubation with erythritol did not lead to a decrease in release of IL-8 or MCP-1. However, when cells were incubated with only erythritol an increase in both IL-8 and MCP-1 was also observed, but to a lesser extent than incubation with high glucose.

When looking into gene expression of angiogenic factors, high glucose induced the expression of VEGFc. This gene is a member of the VEGF family of growth factors. The main member of this family associated with angiogenesis is VEGFa, of which no changes in expression were observed. VEGFc has been associated with the development and remodeling of the lymphatic system (i.e. lymphangiogenic response). However, in the absence of lymphatic tissue VEGFc also induces angiogenesis (15). Pre/co incubation with erythritol did not show differences in VEGFc expression compared to high glucose incubation.

Some effects were observed on the expression of the anti-angiogenic factors, namely the TIMPs. High glucose decreased the expression of TIMP3, which was reversed by pre/co incubation with erythritol. TIMP3 is a member of the TIMP family, which show MMP inhibiting capacity. TIMP3 is a potent angiogenesis inhibitor by not only inhibiting MMPs but it is also able to block the binding of VEFG to its receptor (16). The attenuation of decrease in TIMP3 expression by erythritol can therefore be seen as an anti-angiogenic effect.

High glucose also seemed to induce a faster rate of tube formation of the endothelial cells. This has also been described in literature (17). Erythritol seemed to attenuate this effect, displaying another anti-angiogenic effect. Inhibition of tube 
formation (and endothelial cell migration) by a dietary product like erythritol has also been shown for olive oil and red wine polyphenols. They reduced angiogenesis through MMP9 and COX-2 inhibition (18). Although, we did not look to protein expression and release of these components, we know that erythritol also influences release and expression of eicosanoids, including $\mathrm{PGE}_{2}$ which is involved in MMP-9 expression $(6 ; 19)$.

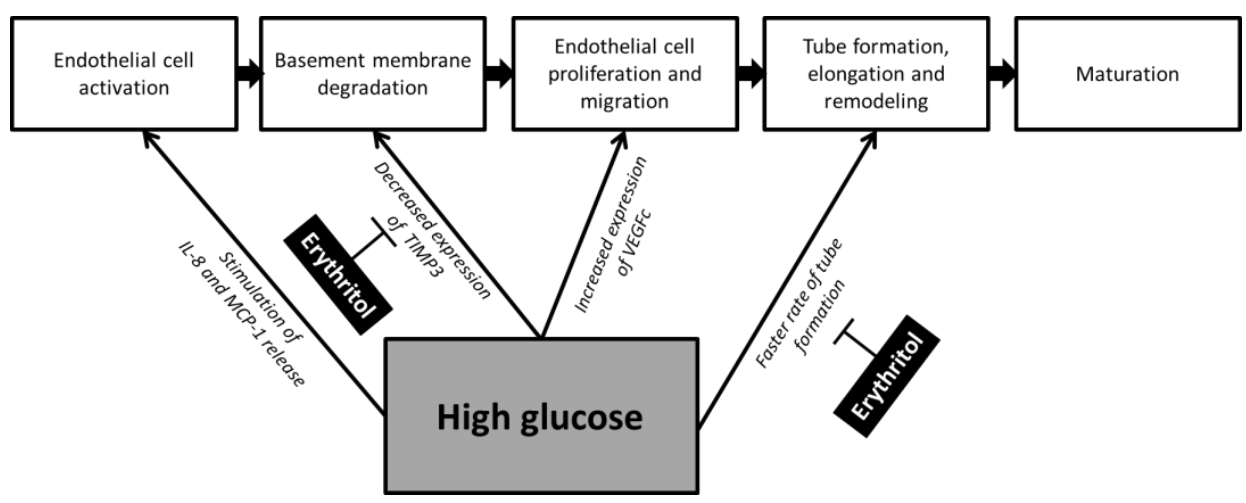

Figure 4: Effects of incubation with high glucose and erythritol on angiogenesis process found in this study.

The objective of this study was to study the effects of erythritol on high glucose induced angiogenesis (figure 4). We observed some anti-angiogenic effects of erythritol, increased expression of TIMP3 and inhibition of tube formation, which indicates that erythritol is a potential anti-angiogenic compound. Therefore erythritol could be of interest as a preventive and/or therapeutic target in the pathology of diabetic complications like diabetic retinopathy and diabetic nephropathy. However, additional, more mechanistic, should be done to determine whether erythritol is a true anti-angiogenic compound. 


\section{References}

1. Carmeliet P: Angiogenesis in health and disease. Nat Med 2003;9:653-660

2. Soares R: Angiogenesis in Diabetes. Unraveling the Angiogenic Paradox The Open Circulation and Vascular Journal 2010;10:3 - 9

3. Falcão M, Falcão-Reis F, Rocha-Sousa A: Diabetic Retinopathy: Understanding Pathologic Angiogenesis and Exploring its Treatment Options. The Open Circulation and Vascular Journal 2010;10:30 - 42

4. Tahergorabi Z, Khazaei M: Imbalance of angiogenesis in diabetic complications: the mechanisms. Int J Prev Med 2012;3:827-838

5. Losso JN: Targeting excessive angiogenesis with functional foods and nutraceuticals. Trends in Food Science \& Technology 2003;14:455-468

6. Boesten DMPHJ, Berger A, de Cock P, Dong H, Hammock BD, den Hartog GJM, Bast A: MultiTargeted Mechanisms Underlying the Endothelial Protective Effects of the Diabetic-Safe Sweetener Erythritol. PLoS One 2013;8:e65741

7. den Hartog GJM, Boots AW, Adam-Perrot A, Brouns F, Verkooijen IWCM, Weseler AR, Haenen GRMM, Bast A: Erythritol is a sweet antioxidant. Nutrition 2010;26:449-458

8. Bisht M, Dhasmana DC, Bist SS: Angiogenesis: Future of pharmacological modulation. Indian J Pharmacol 2010;42:2-8

9. Srinivasan S, Yeh M, Danziger EC, Hatley ME, Riggan AE, Leitinger N, Berliner JA, Hedrick CC: Glucose Regulates Monocyte Adhesion Through Endothelial Production of Interleukin-8. Circulation Research 2003;92:371-377

10. Heidemann J, Ogawa H, Dwinell MB, Rafiee P, Maaser C, Gockel HR, Otterson MF, Ota DM, Lügering N, Domschke W, Binion DG: Angiogenic Effects of Interleukin 8 (CXCL8) in Human Intestinal Microvascular Endothelial Cells Are Mediated by CXCR2. Journal of Biological Chemistry 2003;278:8508-8515

11. Quan $Y$, Jiang CT, Xue B, Zhu SG, Wang X: High glucose stimulates TNFalpha and MCP-1 expression in rat microglia via ROS and NF-kappaB pathways. Acta Pharmacol Sin 2011;32:188-193 12. Lee SK, Kim BS, Yang WS, Kim SB, Park SK, Park JS: High glucose induces MCP-1 expression partly via tyrosine kinase-AP-1 pathway in peritoneal mesothelial cells. Kidney Int 2001;60:55-64 13. Sun J, Xu Y, Dai Z, Sun Y: Intermittent high glucose stimulate MCP-I, IL-18, and PAI-1, but inhibit adiponectin expression and secretion in adipocytes dependent of ROS. Cell Biochem Biophys 2009;55:173-180

14. Niu J, Azfer A, Zhelyabovska O, Fatma S, Kolattukudy PE: Monocyte Chemotactic Protein (MCP)-1 Promotes Angiogenesis via a Novel Transcription Factor, MCP-1-induced Protein (MCPIP). Journal of Biological Chemistry 2008;283:14542-14551

15. Benest AV, Harper SJ, Herttuala SY, Alitalo K, Bates DO: VEGF-C induced angiogenesis preferentially occurs at a distance from lymphangiogenesis. Cardiovascular Research 2008;78:315323

16. Qi JH, Ebrahem Q, Ali M, Cutler A, Bell B, Prayson N, Sears J, Knauper V, Murphy G, AnandApte B: Tissue Inhibitor of Metalloproteinases-3 Peptides Inhibit Angiogenesis and Choroidal Neovascularization in Mice. PLoS One 2013;8:e55667

17. Shigematsu S, Yamauchi K, Nakajima K, lijima S, Aizawa T, Hashizume K: D-Glucose and insulin stimulate migration and tubular formation of human endothelial cells in vitro. Am J Physiol 1999;277:E433-438

18. Scoditti E, Calabriso N, Massaro M, Pellegrino M, Storelli C, Martines G, De Caterina R, Carluccio MA: Mediterranean diet polyphenols reduce inflammatory angiogenesis through MMP-9 and COX-2 inhibition in human vascular endothelial cells: a potentially protective mechanism in atherosclerotic vascular disease and cancer. Arch Biochem Biophys 2012;527:81-89 19. Yen JH, Kocieda VP, Jing H, Ganea D: Prostaglandin E2 induces matrix metalloproteinase 9 expression in dendritic cells through two independent signaling pathways leading to activator protein 1 (AP-1) activation. J Biol Chem 2011;286:38913-38923 
Chapter 8

\section{Erythritol protects HIT-T15 cells from high glucose induced damage}

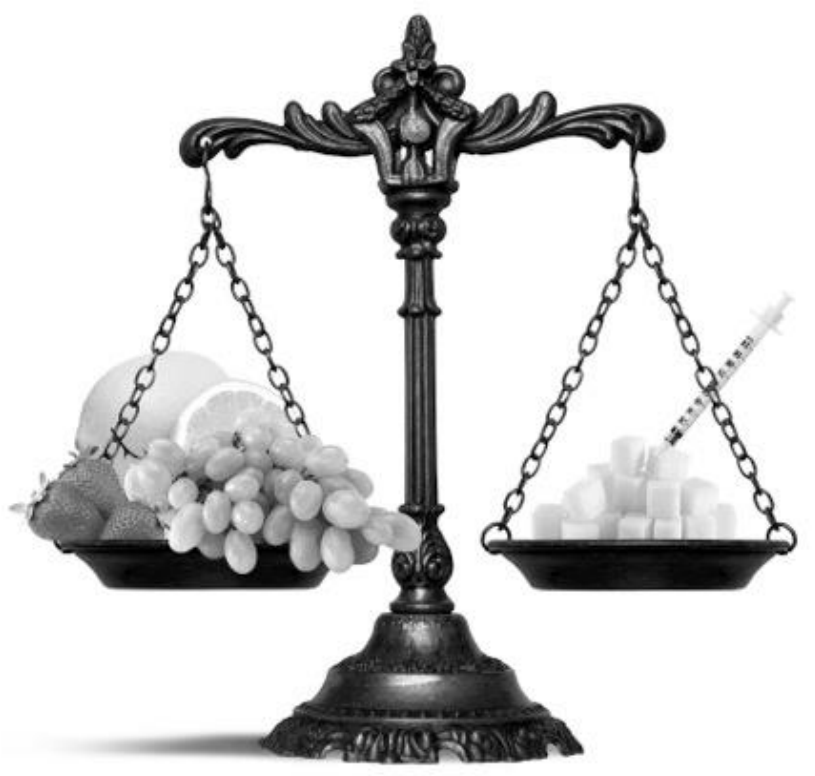

Daniëlle M.P.H.J. Boesten

Gertjan J.M. den Hartog

Peter de Cock

Douwina Bosscher

Aalt Bast 


\title{
Chapter 8
}

\begin{abstract}
Hyperglycemia, as occurring during diabetes, has a harmful effect on the function and development of beta cells. Consequently, chronic hyperglycemia will result in beta cell dysfunction and ultimately cell death. In previous studies erythritol, a polyol bulk sweetener, has been shown to prevent loss of ex vivo endothelium dependent vasorelaxation in diabetic rats and protect endothelial cells during exposure to high concentrations of glucose in vitro. Extending these studies, we investigated the potential of erythritol to protect beta cells against glucose induced cell death and beta cell dysfunction. The hamster beta cell line HIT-T15 was used as a model. After incubation with glucose (with or without erythritol) viability, insulin secretory function and expression of genes involved in apoptosis and insulin secretion were investigated. Incubation with glucose resulted in a dose-dependent decrease in viability of beta cells which was attenuated by erythritol. Additionally, erythritol inhibited high glucose induced hypersecretion of insulin.
\end{abstract}




\section{Introduction}

Diabetes mellitus is one of the most prevailing chronic diseases worldwide. Generally, $90-95 \%$ of diabetes is type 2 , which is historically regarded as a disease of the elderly, however the age of onset is decreasing (1). Worldwide, there are almost 400 million people with diabetes, and this will only increase in the coming years (2). Type 2 diabetes is characterized by hyperglycemia, which is the result of deficiencies in insulin action and insulin secretion (3).

Beta cell function is critical in the etiology of type 2 diabetes (4). Beta cells reside in the pancreas in clusters known as the islets of Langerhans. They are adapted to sense blood glucose levels and can adjust insulin secretion accordingly (5). Glucose is therefore a critical determinant of beta cell function. Prolonged exposure of beta cells to elevated levels of glucose is known to contribute to the development of beta cell dysfunction and ultimately beta cell apoptosis (6-8).

Erythritol (1,2,3,4-butanetetrol; ERT) is a simple polyol that occurs naturally in some fruits and fermented food (9). It is $60-80 \%$ as sweet as sucrose (i.e. table sugar). However, unlike other polyols, more than $90 \%$ of ingested ERT is efficiently absorbed into the bloodstream in the small intestine and excreted unchanged in the urine. ERT is well tolerated and has no adverse effects, even after consumption of large quantities $(10 ; 11)$. In addition, oral intake of ERT does not affect plasma glucose nor insulin levels, which makes it a useful and safe food component for patients with diabetes $(12 ; 13)$. In previous studies ERT prevented loss of ex vivo endothelium dependent vasorelaxation in streptozotocin diabetic rats and protected endothelial cells during exposure to high concentrations of glucose in vitro $(14 ; 15)$. Extending these studies, we investigated the potential of ERT to protect beta cells against glucose induced dysfunction and cell death in the hamster beta cell line HIT-T15.

\section{Methods and materials}

\section{Chemicals}

All chemicals were purchased from Sigma-Aldrich (Steinheim, Germany) unless stated otherwise. Roswell Park Memorial Institute (RPMI) 1640 medium, Hank's Balanced Salt Solution (HBSS), trypsin-EDTA, non-heat inactivated fetal calf serum (FCS), and penicillin/streptomycin were obtained from Gibco (Breda, The Netherlands). ERT was kindly provided by Cargill (Vilvoorde, Belgium). 


\section{Cell culture}

HIT-T15 cell line CRL-1777 was obtained from American Type Culture Collection (ATCC). Cells were cultured in RPMI 1640 + Glutamax with $10 \%$ non-heat inactivated fetal calf serum and $1 \%$ penicillin/streptomycin (Gibco, Breda, The Netherlands). Cells were maintained at $37^{\circ} \mathrm{C}$ in a $5 \% \mathrm{CO} 2$ atmosphere. For experiments, cells were seeded in 6 or 12 well plates. After overnight attaching, medium was removed and cells were washed with HBSS. New medium with ERT (final concentration: $5 \mathrm{mM}$ ) or vehicle (medium) was added to the cells. After 1 hour incubation glucose (final concentration 30 or $45 \mathrm{mM}$ ) or vehicle (medium) was added. Subsequently, cells were incubated for 24 or 48 hours.

\section{Cell Viability}

After incubation, all cell material including medium and HBSS was collected and centrifuged ( 5 minutes, $500 \mathrm{xg}$ ) and used to determine viability of the cells using the trypan blue exclusion assay. Cells suspensions were diluted 1:1 in 0.4\% trypan blue dye and loaded in a Countess Chamber. Cells were counted and cell size was determined using the Countess Cell Counter (Life Technologies, Bleiswijk, The Netherlands). Population doubling time (PDT) was calculated with the formula: (t1 - t0) /3.32 (log $\mathrm{Ne}-\log \mathrm{Nb})$. Where t0 is the start of the incubation time and $\mathrm{t} 1$ is the end of the incubation time (in this case 48 hours), $\mathrm{Nb}$ is the cell number at the beginning of the incubation time and $\mathrm{Ne}$ is the cell number at the end of the incubation time.

\section{Insulin release assay}

Insulin release in response to glucose was evaluated in HIT-T15 cells preincubated to different concentrations of glucose in the presence or absence of ERT. After 24 or 48 hour incubation, Krebs Ringer Bicarbonate buffer $(118.5 \mathrm{mmol} / \mathrm{l} \mathrm{NaCl}, 2.54$ $\mathrm{mmol} / \mathrm{l} \mathrm{CaCl}, 1.19 \mathrm{mmol} / / \mathrm{KH}_{2} \mathrm{PO}_{4}, 4.75 \mathrm{mmol} / \mathrm{l} \mathrm{KCl}, 25 \mathrm{mmol} / \mathrm{l} \mathrm{NaHCO}, 1.19$ $\mathrm{mmol} / \mathrm{l} \mathrm{MgSO}_{4}, 10 \mathrm{mmol} / \mathrm{l}$ HEPES, 0.1\% BSA, pH 7.4) was added for 1 hour. Subsequently, cells were challenged with $16.7 \mathrm{mM}$ glucose in Krebs Ringer Bicarbonate buffer for 1 hour. After the incubation, supernatants were collected and stored at $-20^{\circ} \mathrm{C}$ until the insulin determination was performed. Cellular insulin content was determined following overnight acid/ethanol extraction. Insulin was measured using an enzyme-linked immunosorbent assay using hamster insulin as a standard (Crystal Chem, Downers Grove, IL, USA).

\section{Gene expression}

RNA was isolated from Qiazol suspended cells according to the manufacturer's protocol and quantified spectrophotometrically. Reverse transcription reaction was 
performed using 500 ng of RNA, which was reverse-transcribed into cDNA using iScript cDNA synthesis kit (Biorad, Veenendaal, The Netherlands). Next, real time PCR was performed with a BioRad MyiQ iCycler Single Color RT-PCR detection system using Sensimix ${ }^{T M}$ Plus SYBR and Fluorescein (Quantace-Bioline, Alphen a/d Rijn, The Netherlands), $5 \mu$ l diluted (10x) cDNA, and $0.3 \mu \mathrm{M}$ primers in a total volume of $25 \mu \mathrm{l}$. PCR was conducted as follows: denaturation at $95^{\circ} \mathrm{C}$ for 10 minutes, followed by 40 cycles of $95^{\circ} \mathrm{C}$ for 15 seconds and $60^{\circ} \mathrm{C}$ for 45 seconds. After PCR a melt curve $\left(60-95^{\circ} \mathrm{C}\right)$ was produced for product identification and purity. Tubulin and $\beta$-actin were included as internal control. Primer sequences are shown in table 1. Data were analyzed using the MylQ software system (BioRad) and were expressed as relative gene expression (fold change) using the $2^{\Delta \Delta \mathrm{Ct}}$ method.

Table 1: Primer sequences for genes used for gene expression analysis

\begin{tabular}{lll}
\hline Gene & Forward (5' to $\mathbf{3}^{\prime}$ ) & Reverse (5' to $\mathbf{3}^{\prime}$ ) \\
\hline Tubulin & CTCGCATCCACTTCCCTC & ATGCCC TCACCCACGTAC \\
$\boldsymbol{\beta}$-actin & ATGGATGACGATATCGCTGCGC & AGTCCATCACAATGCCAGTGGT \\
Bax & AGAGGCAGCGGCAGTGAT & CGATCCTGGATGAAACCCT \\
PDX-1 & CGCGTCCAGCTCCCTTT & TGCCCACTGGCCTTTCC \\
Insulin & AGGACCCACAAGTGGAACAACT & CAACGCCAAGGTCTGAAGGT \\
\hline
\end{tabular}

\section{Caspase 3/7 activation}

After 48 hour incubation cells were labelled with $5 \mu \mathrm{M}$ Caspase 3/7 Green Detection Reagent (Life Technologies). Fluorescence was measured on a spectrofluorometer (Spectra Max M2, Molecular Devices) with $\lambda_{\text {ex }}$ set at $502 \mathrm{~nm}$ and $\lambda_{\text {em }}$ at 530 . As a positive control, cells were incubated with $500 \mu \mathrm{M}$ hydrogen peroxide $\left(\mathrm{H}_{2} \mathrm{O}_{2}\right)$ for 1 hour.

\section{Statistical analysis}

The effect of high glucose (HG) incubation and effects of ERT were tested using Student's t-test for independent samples or the Mann-Whitney $U$ test when not normally distributed. P-values $<0.05$ were considered statistically significant and $p$ values $<0.1$ were considered statistical trends. Statistical analyses were analyzed with SPSS for Windows (version 20.0; SPSS Inc., Chicago, IL, USA).

\section{Results}

The effect of incubating HIT-T15 with HG, ERT or a combination was investigated by evaluating the cell viability using trypan blue exclusion assay. When cells were incubated with HG for 24 hours no differences in viability were observed (figure 1A). Longer HG incubation (48 hours) resulted in an almost 3-fold increase in the 


\section{Chapter 8}

percentage of dead cells, which was attenuated by addition of ERT (figure 1B). Moreover, under normal glucose conditions incubation with ERT did not result in differences in viability compared to incubation without ERT. Additionally, population doubling times (PDT) of the different conditions were determined, with an average PDT of 32 hours (figure 1C). No significant differences were found, though incubation with $30 \mathrm{mM}$ glucose resulted in a slight non-significant decrease in PDT from an average of 32 hours to 29 hours. Also no difference in cell size was observed (figure 1D).

A
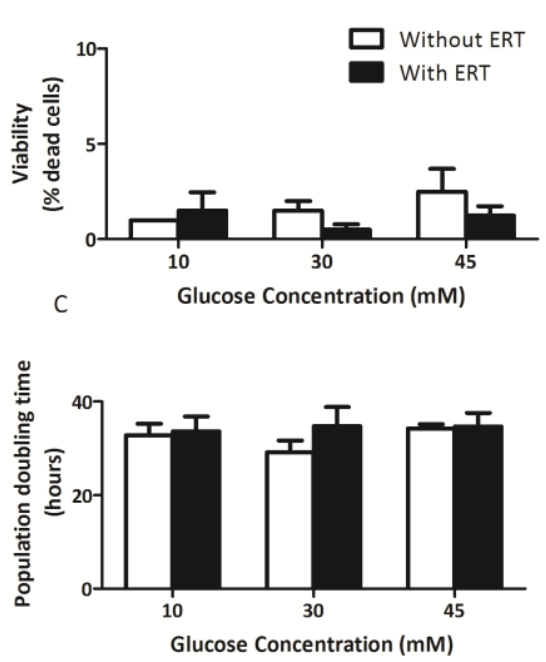

B
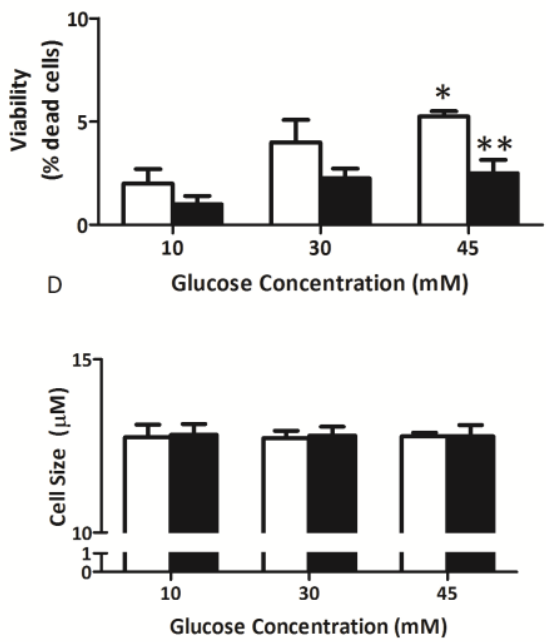

Figure 1: Effect on viability of HIT-T15 cells incubated with 10, 30 and $45 \mathrm{mM}$ glucose in the presence of absence of erythritol (ERT) for 24 hours (A) and 48 hours (B). For cells incubated for 48 hours population doubling time (C) and cell size (D) was determined. Data are expressed as mean \pm standard error of four independent experiments. $*=p<0.05$ compared to $10 \mathrm{mM}$ (normal glucose); ${ }^{* *}=p<0.05$ compared to no ERT.

Insulin release was induced by exposing the cells to $16.7 \mathrm{mM}$ glucose after they had been incubated with different glucose concentrations for 24 or 48 hours. Results show that incubation with 30 and $45 \mathrm{mM}$ glucose for 24 hours led to a dose dependent increase in insulin release (figure 2A). Incubation for 48 hours with 45 $\mathrm{mM}$ glucose resulted in a lower insulin release (figure $2 \mathrm{~B}$ ). Glucose in combination with ERT did not result in a change of insulin release compared to normal glucose. Additionally, insulin content of the cells was determined after induction of insulin release by exposing the cells to $16.7 \mathrm{mM}$ glucose (figure $2 \mathrm{C}$ ). Average insulin content was $\sim 2200 \mathrm{ng}$ insulin per $\mathrm{mg}$ protein which is comparable to the reported insulin content of the cell line ( $2600 \mathrm{ng} / \mathrm{mg}$ protein) (16). 

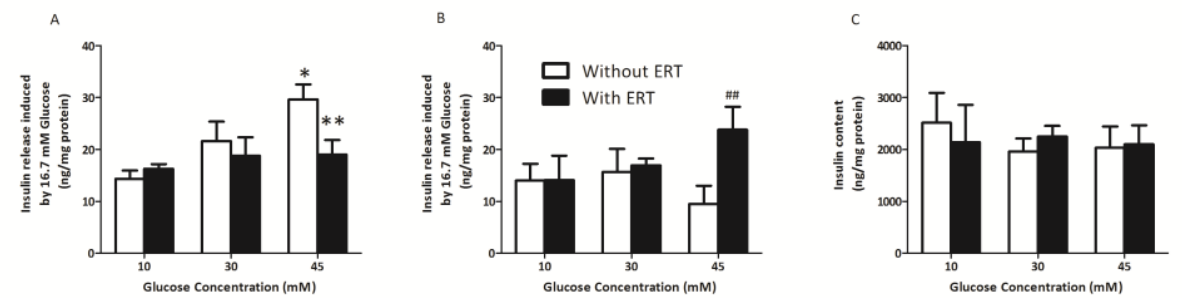

Figure 2: Insulin secretion induced by exposure to $16.7 \mathrm{mM}$ glucose of HIT-T15 cells cultured for 24 (A) or 48 (B) hours with 10, 30 or $45 \mathrm{mM}$ glucose in the presence or absence of erythritol (ERT). Figure $2 \mathrm{C}$ represents the insulin content after inducing insulin release with $16.7 \mathrm{mM}$ glucose of HIT-T15 cells cultured for 48 hours with 10, 30 or $45 \mathrm{mM}$ glucose in the presence or absence of ERT. Data are expressed as mean \pm standard error of three independent experiments. ${ }^{*}=p<0.05$ compared to $10 \mathrm{mM}$ (normal glucose); ${ }^{* *}=p<0.05$ compared to no ERT, \#\#=p<0.1 compared to no ERT.

To explore mechanisms by which ERT can protect beta cells, we investigated the expression of genes related to apoptosis after 24 hour incubation. Incubation with $45 \mathrm{mM}$ glucose for 24 hours seems to lower the gene expression of insulin, while increasing the expression of the pro-apoptotic protein $\mathrm{Bcl}-2$-associated $\mathrm{X}$ protein (BAX) (figure 3A and 3B). Expression of the anti-apoptotic and cytoprotective gene Pancreatic and duodenal homeobox 1 ( $P d x 1)$ seems to be induced after 24 hours incubation when cells were pre/coincubated with ERT (figure 3C). ERT in combination with $30 \mathrm{mM}$ glucose also lowered the expression of insulin.
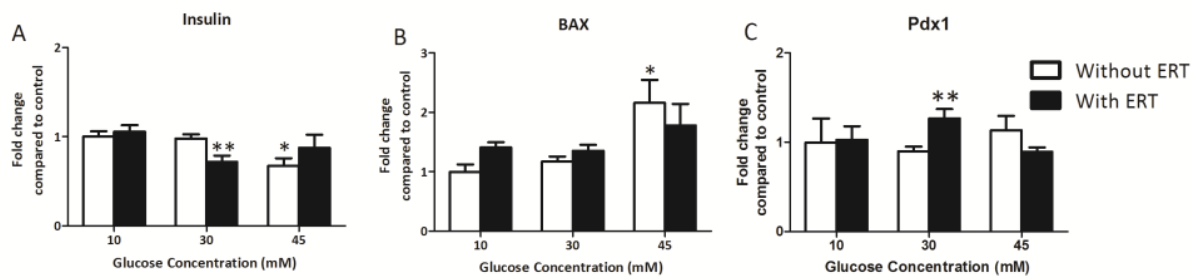

Figure 3: Effect on gene expression of insulin (A), BAX (B) and Pdx1 (C) of HIT-T15 cells incubated with 10, 30 and $45 \mathrm{mM}$ glucose in the presence or absence of erythritol (ERT) for 24 hours. Data are expressed as mean \pm standard error of three independent experiments. * $=p<0.05$ compared to $10 \mathrm{mM}$ (normal glucose); ${ }^{* *}=p<0.05$ compared to no ERT.

To investigate the possible involvement of caspases in the observed cell death after 48 hours, cells were labelled with a caspase 3/7 detection reagent. No significant changes in caspase $3 / 7$ activation were observed in cells cultured with different 
glucose concentrations for 48 hours. Incubation with $500 \mu \mathrm{M} \mathrm{H}_{2} \mathrm{O}_{2}$ for 1 hour (positive control) increased caspase $3 / 7$ activation (figure 4).

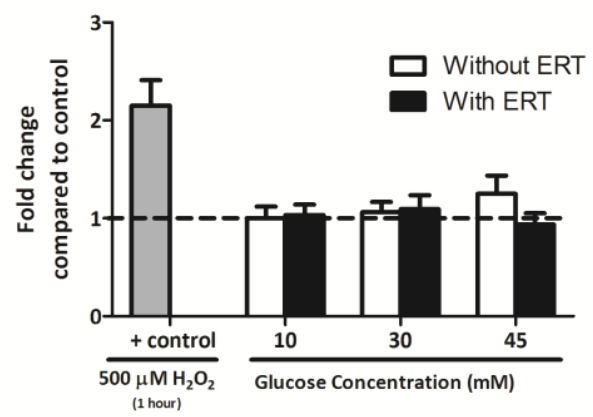

Figure 4: Effect on caspase 3/7 activation of HIT-T15 cells incubated with 10, 30 and $45 \mathrm{mM}$ glucose in the presence or absence of erythritol (ERT) for 48 hours.

\section{Discussion}

In previous studies ERT has been shown to prevent loss of ex vivo endothelium dependent vasorelaxation in streptozotocin diabetic rats and protect endothelial cells during exposure to high concentrations of glucose $(14 ; 15)$. The aim of the experiments described in this paper was to investigate the ability of ERT to prevent HG induced cell death and cell dysfunction in another cell type that plays an important role in diabetes, the pancreatic beta cell.

We observed an increase in the amount of dead cells when the cells were incubated with $45 \mathrm{mM}$ glucose for 48 hours. This is in line with other studies which observed that chronic exposure to HG results in beta cell death $(17 ; 18)$. When the demand for insulin is high, beta cells compensate to restore glucose homeostasis by increasing their number (hyperplasia) and size (hypertrophy) (19). Additionally, glucose itself is an important regulator of beta cell proliferation (20-22). We determined the cell size of HIT-T15 after 48 hours incubation, but we did not detect any changes between the conditions. Neither did we observe any significant changes the rate of proliferation. However we saw a slight decrease in PDT when cells were incubated with $30 \mathrm{mM}$ glucose for 48 hours. Although PDT is not the best method to measure this, it could indicate a higher rate of proliferation in these cells, which is in line with the observation that glucose stimulates proliferation.

It is known that when the need for insulin secretion is higher than normal (e.g. during hyperglycemia), an increased beta cell glucose sensitivity occurs as a 
compensatory mechanism. This leads to hypersecretion of insulin (i.e. more insulin is secreted than normally would be expected for the level of glycemia). Continuous overstimulation of the beta cells will eventually lead to a depletion of insulin stores, subsequently leading to a reduced insulin secretion and a deterioration of beta cell function $(23 ; 24)$. In our in vitro system insulin release was induced by exposing the cells to $16.7 \mathrm{mM}$ glucose after they had been incubated with different glucose concentrations for 24 or 48 hours. Results show that incubation with $45 \mathrm{mM}$ glucose for 24 hours led to a hypersecretion of insulin, which was attenuated by pre/coincubation with ERT. This hypersecretion of insulin was not observed when cells were incubated for 48 hours, in contrast, cells incubated with $45 \mathrm{mM}$ glucose showed a non-significant decrease in insulin release which may be indicative of depletion of insulin stores. Pre/coincubation with ERT kept insulin release levels in the normal range. On transcriptional level we also found a decrease in expression of insulin when cells were incubated with $45 \mathrm{mM}$ for 24 hours, this was not found when cells were pre/coincubated with erythritrol. ERT in combination with $30 \mathrm{mM}$ glucose also lowered the expression of insulin after 24 hour incubation. However, we did not see any effects on the functional insulin release assay in this condition. It is possible that this decrease in insulin expression is compensated by expression or activity of enzymes involved in insulin biosynthesis. Since hypersecretion of insulin can deplete insulin stores, we also determined the insulin content of the cells after 48 hour exposure. No significant changes were observed, it might be that changes in insulin content will appear after longer incubation times.

The decrease in insulin release after 48 hours occurred at the same time as the decrease in cell viability. It might be that beta cell dysfunction plays a role in the observed cell death after 48 hours. Beta cell apoptosis is thought to play an important role in the progression of type 2 diabetes (17), so we determined the expression of several genes involved in apoptosis. BAX is found in the cytosol of all living cells. Upon initiation of apoptotic signalling, BAX undergoes a conformation shift after which it inserts into mitochondrial membranes. This results in the release of cytochrome $\mathrm{C}$ and other pro-apoptotic factors into the cytosol, subsequently leading to activation of caspases $(25 ; 26)$. It was found that in isolated human islets BAX showed a higher expression compared with $\mathrm{Bcl}-2$ (27). We also found gene expression of BAX but hardly any detectable gene expression levels of $\mathrm{Bcl}-2$ (data not shown). The expression of BAX was increased in cells incubated with $45 \mathrm{mM}$ for 24 hours, which also showed a decrease in viability after 48 hours incubation. It is possible that $45 \mathrm{mM}$ glucose shifted the balance between pro- and antipoptic signals towards apoptosis, which could also explain the observed cell death. The expression of BAX was also increased when cells were incubated with ERT alone. 


\section{Chapter 8}

Because we do not see any effects of ERT incubation on cell viability or cell function, the observed increase did not result in any damaging effects.

The gene Pdx1 encodes a transcription factor which plays a key role in pancreatic development, mature beta cell function and insulin signaling (28). Chronic hyperglycemia leads to a decrease in Pdx1 expression (29). Downregulation of this gene impairs glucose stimulated insulin secretion (28). We observed an increase in $\mathrm{Pdx} 1$ expression when cells were incubated with $30 \mathrm{mM}$ glucose and ERT compared to cells incubated with $30 \mathrm{mM}$ glucose alone. Due to its role in many processes concerning maintenance of beta cell neogenesis, differentiation and apoptosis the increase in $\mathrm{Pdx} 1$ expression can be seen as protective.

Caspase 3 is a key mediator of apoptosis in mammalian cells. Exposure of the beta cell line MIN6N8 to HG induced cell death mediated by caspase 3 activation (17). Caspase 3 can be activated by Bax (30), so we performed an assay to detect caspase 3 and its downstream target caspase 7 activation in our cells. We used a detection reagent which does not require wash steps, this helps preserve fragile apoptotic cells commonly lost during wash steps. This assay allows live cells monitoring of caspase $3 / 7$ activation. No significant differences in caspase 3/7 activation after 48 hours were observed, however, it is possible that longer incubation time will lead to a more pronounced effect on caspase activation. Other types of cell death like necrosis and autophagy have also been linked to reduced beta cell mass in diabetes (19). It is possible that these types also play a role in the increase of death cells in our system, since trypan blue does not distinguish between necrotic and apoptotic cells.

In conclusion, this study shows that ERT protects beta cells under HG conditions. ERT prevented HG induced cell death. Moreover, cells incubated with ERT did not display increased glucose sensitivity and hypersecretion of insulin, which implies that ERT prevented beta cell dysfunction. These data extend our previous findings that ERT can prevent diabetic complications. As in our previous studies in endothelial cells, we observed that ERT was able to attenuate damage and improve function. ERT can therefore be regarded as a compound that can have protective effects during HG conditions on multiple targets (e.g. endothelium, pancreas). 


\section{References}

1. Venkat Narayan KM, Gregg EW, Fagot-Campagna A, Engelgau MM, Vinicor F: Diabetes - a common, growing, serious, costly, and potentially preventable public health problem. Diabetes Research and Clinical Practice 2000;50, Supplement 2:S77-S84

2. Whiting DR, Guariguata L, Weil C, Shaw J: IDF Diabetes Atlas: Global estimates of the prevalence of diabetes for 2011 and 2030. Diabetes Research and Clinical Practice 2011;94:311-321

3. Alberti KG, Zimmet PZ: Definition, diagnosis and classification of diabetes mellitus and its complications. Part 1: diagnosis and classification of diabetes mellitus provisional report of a WHO consultation. Diabet Med 1998;15:539-553

4. Ashcroft Frances M, Rorsman P: Diabetes Mellitus and the $\beta$ Cell: The Last Ten Years. Cell 2012;148:1160-1171

5. Fridlyand L, Philipson L: Glucose sensing in the pancreatic beta cell: a computational systems analysis. Theoretical Biology and Medical Modelling 2010;7:15

6. Rossetti L, Giaccari A, DeFronzo RA: Glucose Toxicity. Diabetes Care 1990;13:610-630

7. Eizirik DL, Korbutt GS, Hellerstr, $\mathrm{xF}, \mathrm{m}$ C: Prolonged exposure of human pancreatic islets to high glucose concentrations in vitro impairs the beta-cell function. The Journal of Clinical Investigation 1992;90:1263-1268

8. Marshak S, Leibowitz G, Bertuzzi F, Socci C, Kaiser N, Gross DJ, Cerasi E, Melloul D: Impaired beta-cell functions induced by chronic exposure of cultured human pancreatic islets to high glucose. Diabetes 1999;48:1230-1236

9. Shindou T, Sasaki Y, Miki H, Eguchi T, Hagiwara K, Ichikawa T: Determination of Erythritol in Fermented Foods by High Performance Liquid Chromatography. Food Hygiene and Safety Science (Shokuhin Eiseigaku Zasshi) 1988;29:419-422_411

10. Munro IC, Berndt WO, Borzelleca JF, Flamm G, Lynch BS, Kennepohl E, Bär EA, Modderman J, Bernt WO: Erythritol: an interpretive summary of biochemical, metabolic, toxicological and clinical data. Food Chem Toxicol 1998;36:1139-1174

11. Bernt WO, Borzelleca JF, Flamm G, Munro IC: Erythritol: a review of biological and toxicological studies. Regul Toxicol Pharmacol 1996;24:S191-197

12. Bornet FRJ, Blayo A, Dauchy F, Slama G: Plasma and Urine Kinetics of Erythritol after Oral Ingestion by Healthy Humans. Regulatory Toxicology and Pharmacology 1996;24:S280-S285

13. Ishikawa M, Miyashita M, Kawashima Y, Nakamura T, Saitou N, Modderman J: Effects of Oral Administration of Erythritol on Patients with Diabetes. Regulatory Toxicology and Pharmacology 1996;24:S303-S308

14. den Hartog GJM, Boots AW, Adam-Perrot A, Brouns F, Verkooijen IWCM, Weseler AR, Haenen GRMM, Bast A: Erythritol is a sweet antioxidant. Nutrition 2010;26:449-458

15. Boesten DMPHJ, Berger A, de Cock P, Dong H, Hammock BD, den Hartog GJM, Bast A: Multi-Targeted Mechanisms Underlying the Endothelial Protective Effects of the DiabeticSafe Sweetener Erythritol. PLoS One 2013;8:e65741

16. Santerre RF, Roland AC, Crisel RMD, Sharp JD, Schmidt RJ, Williams DC, Wilson CP: Insulin Synthesis in a Clonal Cell Line of Simian Virus 40-Transformed Hamster Pancreatic Beta Cells. Proceedings of the National Academy of Sciences of the United States of America 1981;78:4339-4343

17. Kim W-H, Lee JW, Suh YH, Hong SH, Choi JS, Lim JH, Song JH, Gao B, Jung MH: Exposure to Chronic High Glucose Induces $\beta$-Cell Apoptosis Through Decreased Interaction of Glucokinase With Mitochondria: Downregulation of Glucokinase in Pancreatic $\beta$-Cells. Diabetes 2005;54:2602-2611

18. Yang Y, Wang W, Liu Y, Guo T, Chen P, Ma K, Zhou C: alpha-lipoic acid inhibits high glucose-induced apoptosis in HIT-T15 cells. Dev Growth Differ 2012;54:557-565

19. Cerf ME: Beta cell dysfunction and insulin resistance. Frontiers in Endocrinology 2013;4 
20. Kwon G, Marshall CA, Pappan KL, Remedi MS, McDaniel ML: Signaling elements involved in the metabolic regulation of mTOR by nutrients, incretins, and growth factors in islets. Diabetes 2004;53 Suppl 3:S225-232

21. Alonso LC, Yokoe T, Zhang P, Scott DK, Kim SK, O'Donnell CP, Garcia-Ocaña A: Glucose infusion in mice: a new model to induce beta-cell replication. Diabetes 2007;56:1792-1801

22. Porat S, Weinberg-Corem N, Tornovsky-Babaey S, Schyr-Ben-Haroush R, Hija A, StolovichRain M, Dadon D, Granot Z, Ben-Hur V, White P, Girard Christophe A, Karni R, Kaestner Klaus H, Ashcroft Frances M, Magnuson Mark A, Saada A, Grimsby J, Glaser B, Dor Y: Control of Pancreatic $\beta$ Cell Regeneration by Glucose Metabolism. Cell Metabolism 2011;13:440-449

23. Leahy LJ: Detrimental Effects of Chronic Hyperglycemia on the Pancreatic $\beta$-Cell. In Diabetes Mellitus: A Fundamental and Clinical Text LeRoith D, Taylor SI, Olefsky JM, Eds. Philadelphia, Lippincott Williams \& Wilkins, 2004, p. $115-127$

24. Poitout V, Robertson RP: Glucolipotoxicity: Fuel Excess and $\beta$-Cell Dysfunction. Endocrine Reviews 2008;29:351-366

25. Goping IS, Gross A, Lavoie JN, Nguyen M, Jemmerson R, Roth K, Korsmeyer SJ, Shore GC: Regulated Targeting of BAX to Mitochondria. The Journal of Cell Biology 1998;143:207-215

26. Hui H, Dotta F, Mario UD, Perfetti R: Role of caspases in the regulation of apoptotic pancreatic islet beta-cells death. Journal of Cellular Physiology 2004;200:177-200

27. Thomas D, Yang H, Boffa DJ, Ding R, Sharma VK, Lagman M, Li B, Hering B, Mohanakumar T, Lakey J, Kapur S, Hancock WW, Suthanthiran M: Proapoptotic bax is hyperexpressed in isolated human islets compared with antiapoptotic bcl-21. Transplantation 2002;74:14891496

28. Brissova M, Shiota M, Nicholson WE, Gannon M, Knobel SM, Piston DW, Wright CVE, Powers AC: Reduction in Pancreatic Transcription Factor PDX-1 Impairs Glucose-stimulated Insulin Secretion. Journal of Biological Chemistry 2002;277:11225-11232

29. Fujimoto K, Polonsky KS: Pdx1 and other factors that regulate pancreatic beta-cell survival. Diabetes, obesity \& metabolism 2009;11 Suppl 4:30-37

30. Cregan SP, MacLaurin JG, Craig CG, Robertson GS, Nicholson DW, Park DS, Slack RS: BaxDependent Caspase-3 Activation Is a Key Determinant in p53-Induced Apoptosis in Neurons. The Journal of Neuroscience 1999;19:7860-7869 
Chapter 9

\section{Oxidative stress markers and cytokine levels in plasma from type 2 diabetics before and after 4 weeks erythritol consumption}

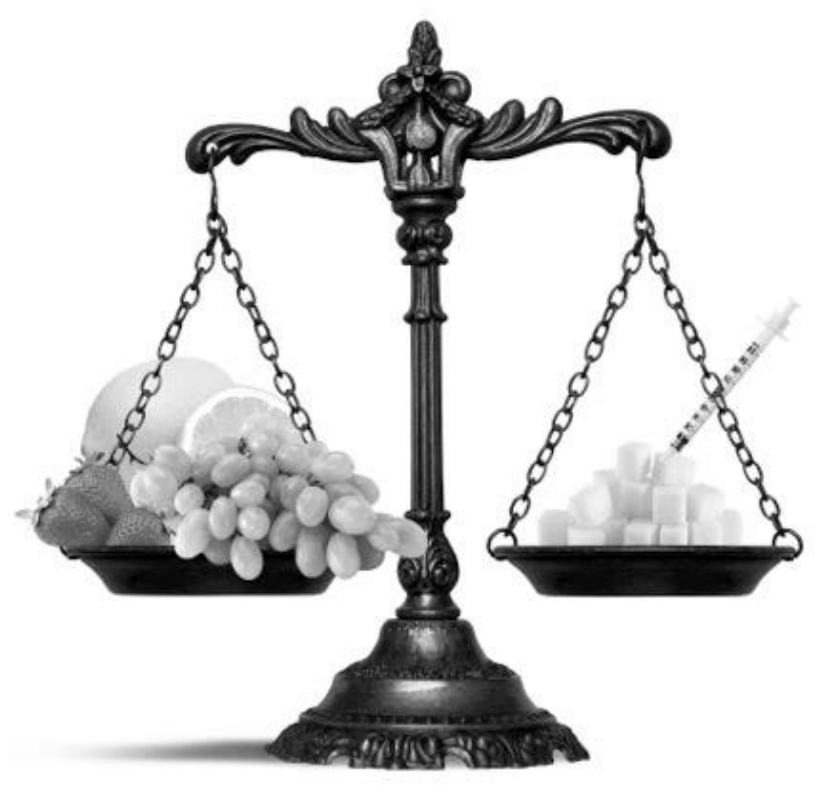

Daniëlle M.P.H.J. Boesten

Gertjan J.M. den Hartog

Marie-José Drittij-Reijnders

Peter de Cock

Douwina Bosscher

Aalt Bast 


\begin{abstract}
Diabetic complications have been linked to oxidative stress and inflammation. In this pilot study we determined the effects of chronic, acute and acute-on-chronic effects of consumption of erythritol on plasma levels of oxidative stress and inflammatory markers. Twenty four type 2 diabetic subjects consumed 36 grams ( 3 x 12 grams) erythritol daily for 4 weeks. In addition, acute and acute-on-chronic effects were determined by taking blood samples before and two hours after subjects consumed 24 grams of erythritol as a single dose. TEAC, as a marker of overall systemic oxidative stress, and malondialdehyde (MDA), as a marker of lipid peroxidation, were measured. Chronic consumption of erythritol slightly decreased MDA levels in the plasma. Acute consumption lowered TEAC values, which could be attributed to a decrease in uric acid levels. Several cytokines were measured as markers of inflammation. No chronic effects were observed, but acute consumption lowered the concentration of IL-1 $\beta$, IL-10, IL-5 and IFN- - . IL-4 and IL13 showed a trend towards decreased concentrations. These acute changes are promising, but they are not found after chronic consumption, suggesting a limited effect of erythritol. The absence of a control group and the variety of diabetic treatments taken by the subjects of the study make interpretation of the data difficult. Validation of these findings will therefore require a randomized, placebocontrolled study.
\end{abstract}




\section{Introduction}

Diabetes is a major global health problem. It has almost 400 million patients worldwide, and this number will only increase in the coming years, leading to an even heavier social and economic burden (1). Diabetic patients are at risk of developing a number of disabling and life-threatening health problems, e.g. stroke, myocardial infarction and blindness $(1 ; 2)$. Oxidative stress is linked to these complications $(3 ; 4)$. Oxidative stress can lead to a depletion in antioxidant and indeed a reduced antioxidant capacity (lower trolox equivalent antioxidant capacity (TEAC)) is observed in type 2 diabetic subjects (5). Lipid peroxidation is one of the damaging processes induced by excessive radical formation. Malondialdehyde (MDA) is one of the products and has been shown to be related to the severity of diabetic complications (6). Oxidative stress also causes an inflammatory response and inflammation has been shown to play a crucial in the pathogenesis of diabetic complications (7).

Erythritol is a simple polyol compound, used as a low-calorie, tooth-friendly bulk sweetener. It has no impact on blood glucose or insulin levels, which makes a safe food component for diabetic patients (8; 9). Erythritol is an excellent hydroxyl radical scavenger in vitro and it delayed radical induced hemolysis in red blood cells (10). Furthermore, it protected endothelial cells during exposure to high concentration of glucose in vitro (11). Supplementation with erythritol reduced lipid peroxidation and prevented loss of endothelium dependent vasorelaxation in a rat model $(10 ; 12)$. Extending these studies, we investigated the effects of erythritol consumption by type 2 diabetes patients on oxidative markers (plasma TEAC and MDA) and cytokine profile.

\section{Methods and materials}

\section{Study design}

The pilot study design has been described in Flint et al. (13). Twenty four type 2 diabetic patients with fasting glucose above $126 \mathrm{mg} / \mathrm{dl}$ or treatment with hypoglycemic drugs were enrolled. Enrolled subjects underwent testing at baseline and after four weeks of consumption of 36 grams a day of erythritol. Erythritol was supplied in packets of powder containing 12 grams of erythritol and orange flavouring dissolved in 8 oz of water, these packages were taken 3 times a day for four weeks. In addition, acute and acute-on-chronic effects were determined by taking blood samples before and two hours after subjects consumed 24 grams of erythritol as a single dose (figure 1). Blood samples were collected in heparinized tubes and centrifuged to obtain blood plasma. 


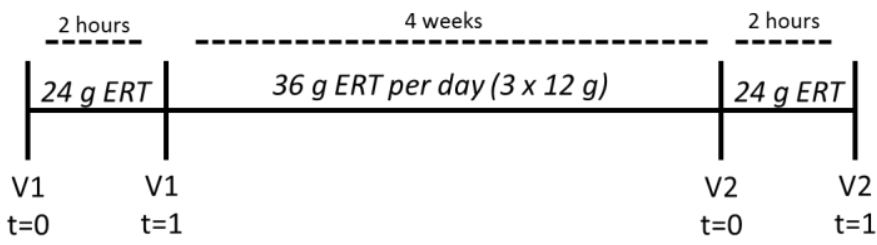

Figure 1: Design of the study and coding used in text and tables. V1 $t=0$ is baseline sample; $\mathrm{V} 1 \mathrm{t}=2$ is sample to study acute effect of consumption of 24 gram erythritol; $\mathrm{V} 2 \mathrm{t}=0$ is sample to study chronic effect after consumption of 36 grams of erythritol per day for four weeks; V2 $t=1$ is sample to study acute-on-chronic effect of consumption of 24 gram erythritol.

\section{Antioxidant capacity measurement}

TEAC was assessed in plasma samples as an index of overall systemic oxidative stress. Plasma was deproteinized by the addition of $10 \%$ trichloroacetic acid to the plasma in a 1:1 ratio. The TEAC was determined in deproteinized plasma according to the method described in (14). The concentration of uric acid in deproteinized plasma was determined with HPLC using a Hypersil BDS C-18 end-capped column (Agilent, Palo Alto, CA) with UV detection at $292 \mathrm{~nm}$.

\section{Malondialdehyde measurement}

MDA was determined in plasma by quantification of the formation of a colored TBA-MDA product. A calibration curve with MDA standards $(0-10 \mu \mathrm{M})$ was run simultaneously to determine the concentration in the samples. Plasma $(100 \mu \mathrm{l})$ or MDA standard $(100 \mu \mathrm{l})$ were mixed with $1 \mathrm{ml}$ of reagent, composed of 10 parts reagent $A$ (12 mM TBA, $0.32 \mathrm{M}$ phosphoric acid and $0.01 \%$ EDTA) and one part of reagent $B(1.5 \mathrm{mg} / \mathrm{ml} B H T$ in ethanol). Samples and standards were heated for 1 hour at $99^{\circ} \mathrm{C}$ in a water bath. After cooling, $500 \mu$ butanol was added and samples and standards were centrifuged for 5 minutes at maximum speed to extract the TBA-MDA product. The TBA-MDA product $(100 \mu \mathrm{l})$ was then transferred into an opaque 96 well plate and fluorescence was measured on a spectrofluorometer (Spectra Max M2, Molecular Devices) with $\lambda_{\mathrm{ex}}$ set at $530 \mathrm{~nm}$ and $\lambda_{\mathrm{em}}$ at $560 \mathrm{~nm}$.

\section{Cytokine measurement}

Cytokines were determined in plasma using the Cytokine 10-plex panel (IL-1 $\beta$, IL-2, IL-4, IL-5, IL-6, IL-10, IL-12, IL-13, IFN- $\gamma$ and TNF $\alpha$ ). This assay was performed according to manufacturer's instructions. This assay uses antibodies coupled to magnetic beads which react with $50 \mu$ plasma. After a series of washes to remove unbound protein, a cytokine-specific biotinylated detection antibody was added to the reaction. After 30 minutes incubation and several washes, a streptavidinphycoerythrin (streptavidin-PE) reporter complex was added to bind biotinylated 
detection antibodies. The plate was then read using the Luminex system and data was analyzed using the Bio-Plex Manager software ${ }^{\mathrm{TM}}$.

\section{Statistical analysis}

Subjects with values below detection range (in the cytokine measurements) were not included in the analysis. In addition, Grubbs outlier test was performed to exclude values that skewed the data. For statistical analysis only subjects with measurement on all four time points were included. Chronic, acute and acute-onchronic effects were tested using a paired Student's t-test or the Wilcoxon signed rank test when not normally distributed. Differences with P-values $<0.05$ were considered statistically significant and those with $\mathrm{P}$-values $<0.1$ were considered trends. Statistical analysis was performed with SPSS for Windows (version 20.0; SPSS Inc., Chicago, IL, USA).

\section{Results}

\section{Subjects}

The general characteristics of subjects in the study are depicted in table 1 . Twentyfour subjects completed the study. Average compliance with the study protocol was $90 \pm 12 \%$ based on count of empty sachets returned at visit 2 . No adverse effects were observed.

Table 1: General characteristics of subjects in the study

\begin{tabular}{ll}
\hline Characteristic & Number of subjects (total number $=24)$ \\
\hline Age (years) & $56 \pm 5$ \\
Male / female & $11 / 13$ \\
Black race & $15(63 \%)$ \\
Weight $(\mathrm{kg})$ & $90.9 \pm 16.8$ \\
Body mass index $(\mathrm{kg} / \mathrm{m} 2)$ & $30.3 \pm 3.4$ \\
\hline
\end{tabular}

\section{TEAC}

One subject was excluded from analysis due to missing values. No effect of chronic consumption of erythritol was observed. Acute and acute-on-chronic consumption of erythritol led to a decrease in TEAC and uric acid concentration. When TEAC values were corrected for uric acid concentration, no differences were observed anymore (table 2). 
Table 2: Plasma TEAC values. Data are expressed as mean \pm standard deviation of 23 subjects. *: $\mathrm{P}<0.05$

\begin{tabular}{llll}
\hline Time point & TEAC $(\mu \mathrm{M})$ & Uric acid $(\mu \mathrm{M})$ & Corrected TEAC $(\mu \mathrm{M})$ \\
\hline V1 $t=0$ & $463.90 \pm 107$ & $289.89 \pm 71$ & $174.02 \pm 41$ \\
V1 $t=1$ & $450.48 \pm 99^{*}$ & $274.87 \pm 67^{*}$ & $175.61 \pm 40$ \\
V2 $t=0$ & $468.52 \pm 118$ & $291.64 \pm 80$ & $176.88 \pm 44$ \\
V2 $t=1$ & $453.31 \pm 115^{*}$ & $279.21 \pm 77^{*}$ & $174.09 \pm 44$ \\
\hline
\end{tabular}

\section{MDA levels}

Three subjects were excluded from analysis due to missing values. Consumption of erythritol for four weeks significantly lowered MDA levels by $4.7 \%$. No acute effects or erythritol consumption were observed. Acute-on-chronic effect showed a trend towards higher MDA levels after consumption of erythritol (table 3).

Table 3: Plasma MDA levels. Data are expressed as mean \pm standard deviation of 21 subjects. *: $\mathrm{P}<0.05 ; \#$ : $\mathrm{P}<0.1$

\begin{tabular}{ll}
\hline Time point & Plasma MDA levels $(\mu \mathrm{M})$ \\
\hline $\mathrm{V} 1 \mathrm{t}=0$ & $1.60 \pm 0.22$ \\
$\mathrm{~V} 1 \mathrm{t}=1$ & $1.63 \pm 0.24$ \\
$\mathrm{~V} 2 \mathrm{t}=0$ & $1.52 \pm 0.24^{*}$ \\
$\mathrm{~V} 2 \mathrm{t}=1$ & $1.58 \pm 0.16^{\#}$ \\
\hline
\end{tabular}

\section{Cytokine levels}

Subjects with values below detection range of the assay were not included. Some subjects had 50-fold higher cytokine concentrations at all four time points, these were excluded after outlier testing. Only subjects with values at all four time points were included in the analysis (number is shown in table 4). Too few subjects had all four IL-6 and TNF $\alpha$ concentrations, so these cytokines were not included in the analysis. No chronic effects on cytokine levels were observed. Acute consumption of erythritol significantly decreased the concentration of IL-1 $\beta$, IL-5 and IL-10, with IL-1 $\beta$ and IL-10 also decreasing after acute-on-chronic consumption. IL-13 and IFN- $\gamma$ showed a trend towards lower levels after acute consumption, with IFN- $\gamma$ significantly decreased after acute-on-chronic consumption. IL-4 showed a trend towards lower levels after acute-on-chronic consumption. 
Table 4: Plasma cytokines levels. Data are expressed as mean \pm standard deviation. *: $\mathrm{P}<0.05 ; \#: \mathrm{P}<0.1$

\begin{tabular}{|c|c|c|c|c|}
\hline Cytokine (pg/ml) & $\mathrm{V} 1 \mathrm{t}=0$ & $\mathrm{~V} 1 \mathrm{t}=1$ & $\mathrm{~V} 2 \mathrm{t}=0$ & $V 2 t=1$ \\
\hline $\mathrm{IL}-1 \beta(n=15)$ & $0.35 \pm 0.06$ & $0.29 \pm 0.03^{*}$ & $0.35 \pm 0.06$ & $0.28 \pm 0.05^{*}$ \\
\hline IL-2 (n= 9) & $5.38 \pm 4.73$ & $4.18 \pm 3.68$ & $4.64 \pm 3.53$ & $4.55 \pm 3.56$ \\
\hline IL-4 ( $=12)$ & $0.37 \pm 0.06$ & $0.34 \pm 0.05$ & $0.39 \pm 0.07$ & $0.34 \pm 0.06^{\#}$ \\
\hline IL-5 $(n=13)$ & $5.42 \pm 3.52$ & $4.44 \pm 2.49^{*}$ & $4.71 \pm 2.37$ & $3.85 \pm 1.10$ \\
\hline IL-10 ( $n=16)$ & $4.04 \pm 1.04$ & $3.06 \pm 0.66^{*}$ & $3.86 \pm 0.97$ & $3.30 \pm 0.78^{*}$ \\
\hline IL-12 ( $n=17)$ & $1.29 \pm 0.66$ & $1.25 \pm 0.78$ & $1.18 \pm 0.48$ & $1.33 \pm 1.01$ \\
\hline IL-13 ( $n=9)$ & $0.82 \pm 0.15$ & $0.70 \pm 0.16^{\#}$ & $0.86 \pm 0.22$ & $0.77 \pm 0.15$ \\
\hline IFN- $-(n=13)$ & $2.47 \pm 0.78$ & $2.04 \pm 0.47^{\#}$ & $2.66 \pm 0.49$ & $1.85 \pm 0.53^{*}$ \\
\hline
\end{tabular}

\section{Discussion}

The objective of this study was to determine the effects of chronic, acute and acute-on-chronic consumption of erythritol on plasma levels of oxidative stress markers and cytokines. Previously, Flint et al. found that erythritol consumption reduced arterial stiffness and improved small vessel endothelial function (13).

In this study we measured two markers of oxidative stress. TEAC as a measurement of overall systemic oxidative stress and MDA, an end product of lipid peroxidation. Consumption of erythritol caused an acute decrease in the TEAC value. However, these decreases can be completely attributed to a lowering of uric acid levels. This phenomenon has been observed before in food intervention studies (unpublished data from our lab). Uric acid is the final oxidation product of purine metabolism in humans. High levels of uric acid in serum have been related to type 2 diabetes, particularly to impaired glucose regulation $(15 ; 16)$. These metabolic processes are expected to change quite rapidly after consumption of a sweet beverage in subjects that have fasted overnight. Since no control group was included in this pilot study, no speculations can be done about the effects of erythritol on this phenomenon. We did not determine the duration of the lowered uric acid concentration, however, there is no reason to assume that it lasts longer than a couple of hours. This implies that the TEAC is unchanged when monitored over longer time periods, as we observed in the chronic treatment. Erythritol does not scavenge $A B T S$ radicals, so its presence in the plasma will not contribute to the plasma TEAC value.

MDA is a marker for lipid peroxidation, a chain reaction in membrane lipids initiated by reactive oxygen species. We found that chronic consumption of 
erythritol led to a slight, but significant, decrease in plasma MDA levels. This is in line with a previous observation by Yokozawa et al., who also found a decrease in lipid peroxidation markers in serum, liver and kidney of rats that received erythritol (12). It is known that erythritol can scavenge hydroxyl radicals and that it alters the expression of components of the mitochondrial electron transport chain, a major site of superoxide production $(10 ; 11)$. These properties of erythritol might explain the decrease in MDA found in this study.

No chronic effects were observed in the plasma concentration of several cytokines. At both visits, consumption of erythritol acutely decreased the levels of IL-1 $\beta$ and IL-10. IL-1 $\beta$ is a pro-inflammatory cytokine excreted by activated macrophages. Recent studies suggest a role for IL-1 $\beta$ in the induction of beta cell death in type 2 diabetes. IL-1 $\beta$ release in islets can cause a vicious cycle of inflammation via selfactivation, most likely due to an imbalance with its natural antagonist IL-1Ra (17). In type 2 diabetes patients increased expression of IL-1 $\beta$ and decreased expression of IL-1Ra has been observed $(18 ; 19)$. In clinical trials, blockade of IL-1 $\beta$ improved beta cell function (17). The observed acute effects of erythritol are promising, although we do not see an effect of chronic erythritol consumption on the concentration of IL-1 $\beta$. IL-10 is an anti-inflammatory cytokine that is produced by a wide range of cell types involved in the immune response. Experiments with animal models suggest it to be a positive regulator of insulin sensitivity (20). We observed a decrease in IL-10 levels after acute erythritol consumption, but again no effects of chronic consumption of erythritol.

Acute consumption of erythritol also decreased IL-5 concentrations. IL-5 is produced by mast cells and Th2 cells. It has a key role in eosinophil proliferation, differentiation, maturation, migration as well as in survival as it prevents eosinophil apoptosis. It is a prominently elevated cytokine in asthma but its role in diabetes is relatively little discussed (21). IFN- $\gamma$ plasma concentrations were also lowered after acute consumption of erythritol. It is predominantly produced by natural killer and $T$ effector cells. IFN- $\gamma$ is critical in innate and adaptive immune responses as an important activator of macrophages. It has been implicated in the pathology of type 1 diabetes, but not much is known about its involvement in type 2 diabetes (22). IL-4 and IL-13 showed a trend toward lower concentrations after erythritol consumption. Both of these cytokines have been studied mainly in their involvement in type 1 diabetes. However, a recent study suggests that IL-13 regulates glucose homeostasis, which could provide a new target to control hyperglycemia in patients with type 2 diabetes (23). 
With some cytokines we observed a wide range of concentrations in the different subjects. This may be due to the variety of blood sugar lowering drugs taken by the subjects (table 5). This diversity renders the interpretation of the data to be difficult, as it might be that these drugs also influence the parameters measured in this study, especially the cytokines.

Table 5: Clinical characteristics of subjects. $\mathrm{ACE}=$ angiotensin converting enzyme; $\mathrm{ARB}=$ angiotensin receptor blocker.

\begin{tabular}{ll}
\hline Medical characteristic & Number of subjects \\
\hline Type 2 diabetes & $24(100 \%)$ \\
Coronary artery disease & $5(21 \%)$ \\
Hypertension & $20(83 \%)$ \\
Cigarette smoking ever & $9(38 \%)$ \\
Statin treatment & $11(46 \%)$ \\
ACE inhibitor or ARB treatment & $13(54 \%)$ \\
Beta blocker treatment & $6(25 \%)$ \\
Calcium channel blocker treatment & $4(17 \%)$ \\
Short-acting insulin treatment & $1(4 \%)$ \\
Other oral diabetes treatment & $21(88 \%)$ \\
Anti-platelet treatment & $7(29 \%)$ \\
\hline
\end{tabular}

It can be concluded that erythritol consumption for four weeks by diabetic subjects reduces oxidative damage but does not change inflammatory status or plasma antioxidant capacity. The acute changes in cytokine levels are promising, but they are not found after chronic consumption, suggesting a limited effects of erythritol on these levels. The absence of a control group and the variety of diabetic treatments taken by the subjects of this study make interpretation of the data difficult. Validation of these findings will therefore require a randomized, placebocontrolled study. 


\section{References}

1. IDF Diabetes Atlas, 6th edn. [article online], 2013. Available from http://www.idf.org/diabetesatlas.

2. Aronson D: Hyperglycemia and the pathobiology of diabetic complications. Adv Cardiol 2008;45:1-16

3. Brownlee M: Biochemistry and molecular cell biology of diabetic complications. Nature 2001;414:813-820

4. Brownlee M: The Pathobiology of Diabetic Complications: A Unifying Mechanism. Diabetes 2005;54:1615-1625

5. Opara EC, Abdel-Rahman E, Soliman S, Kamel WA, Souka S, Lowe JE, Abdel-Aleem S: Depletion of total antioxidant capacity in type 2 diabetes. Metabolism 1999;48:1414-1417

6. Ragbetli C, Dede S, Tanritanir P, Yoruk IH, Ragbetli MC: Determination of Micronutrients and Oxidative Stress Status in the Blood of STZ-Induced Experimental Diabetic Rat Models. Cell Biochem Biophys 2014;

7. Donath MY, Shoelson SE: Type 2 diabetes as an inflammatory disease. Nat Rev Immunol 2011;11:98-107

8. Ishikawa M, Miyashita M, Kawashima Y, Nakamura T, Saitou N, Modderman J: Effects of Oral Administration of Erythritol on Patients with Diabetes. Regulatory Toxicology and Pharmacology 1996;24:S303-S308

9. Bornet FRJ, Blayo A, Dauchy F, Slama G: Plasma and Urine Kinetics of Erythritol after Oral Ingestion by Healthy Humans. Regulatory Toxicology and Pharmacology 1996;24:S280-S285

10. den Hartog GJ, Boots AW, Adam-Perrot A, Brouns F, Verkooijen IW, Weseler AR, Haenen

GR, Bast A: Erythritol is a sweet antioxidant. Nutrition 2010;26:449-458

11. Boesten DMPHJ, Berger A, de Cock $P$, Dong $H$, Hammock BD, den Hartog GJM, Bast A: Multi-Targeted Mechanisms Underlying the Endothelial Protective Effects of the DiabeticSafe Sweetener Erythritol. PLoS One 2013;8:e65741

12. Yokozawa T, Kim HY, Cho EJ: Erythritol attenuates the diabetic oxidative stress through glucose metabolism and lipid peroxidation in streptozotocin-induced diabetic rats. Journal of Agricultural and Food Chemistry 2002;50:5485-5489

13. Flint N, Hamburg N, Holbrook M, Dorsey P, LeLeiko R, Berger A, de Cock P, Bosscher D, Vita J: Effects of erythritol on endothelial function in patients with type 2 diabetes mellitus: a pilot study. Acta Diabetol 2013:1-4

14. Fischer MA, Gransier TJ, Beckers LM, Bekers O, Bast A, Haenen GR: Determination of the antioxidant capacity in blood. Clin Chem Lab Med 2005;43:735-740

15. Hairong N, Zengchang P, Shaojie W, Weiguo G, Lei Z, Jie R, Feng N, Tuomilehto J, Qing Q: Serum uric acid, plasma glucose and diabetes. Diab Vasc Dis Res 2010;7:40-46

16. Meisinger C, Doring A, StockI D, Thorand B, Kowall B, Rathmann W: Uric acid is more strongly associated with impaired glucose regulation in women than in men from the general population: the KORA F4-Study. PLoS One 2012;7:e37180

17. Dinarello CA, Donath MY, Mandrup-Poulsen T: Role of IL-1beta in type 2 diabetes. Curr Opin Endocrinol Diabetes Obes 2010;17:314-321

18. Maedler K, Sergeev P, Ehses JA, Mathe Z, Bosco D, Berney T, Dayer JM, Reinecke M, Halban PA, Donath MY: Leptin modulates beta cell expression of IL-1 receptor antagonist and release of IL-1beta in human islets. Proc Natl Acad Sci U S A 2004;101:8138-8143

19. Maedler K, Sergeev P, Ris F, Oberholzer J, Joller-Jemelka HI, Spinas GA, Kaiser N, Halban PA, Donath MY: Glucose-induced beta cell production of IL-1beta contributes to glucotoxicity in human pancreatic islets. J Clin Invest 2002;110:851-860

20. Hong E-G, Ko HJ, Cho Y-R, Kim H-J, Ma Z, Yu TY, Friedline RH, Kurt-Jones E, Finberg R, Fischer MA, Granger EL, Norbury CC, Hauschka SD, Philbrick WM, Lee C-G, Elias JA, Kim JK: 
Interleukin-10 Prevents Diet-Induced Insulin Resistance by Attenuating Macrophage and Cytokine Response in Skeletal Muscle. Diabetes 2009;58:2525-2535

21. Garcia G, Taillé C, Laveneziana P, Bourdin A, Chanez P, Humbert M: Anti-interleukin-5 therapy in severe asthma. European Respiratory Review 2013;22:251-257

22. Schroder K, Hertzog PJ, Ravasi T, Hume DA: Interferon- $\gamma$ : an overview of signals, mechanisms and functions. Journal of Leukocyte Biology 2004;75:163-189

23. Stanya KJ, Jacobi D, Liu S, Bhargava P, Dai L, Gangl MR, Inouye K, Barlow JL, Ji Y, Mizgerd JP, Qi L, Shi H, McKenzie ANJ, Lee C-H: Direct control of hepatic glucose production by interleukin-13 in mice. The Journal of Clinical Investigation 2013;123:261-271 
Chapter 10

Summary and general discussion

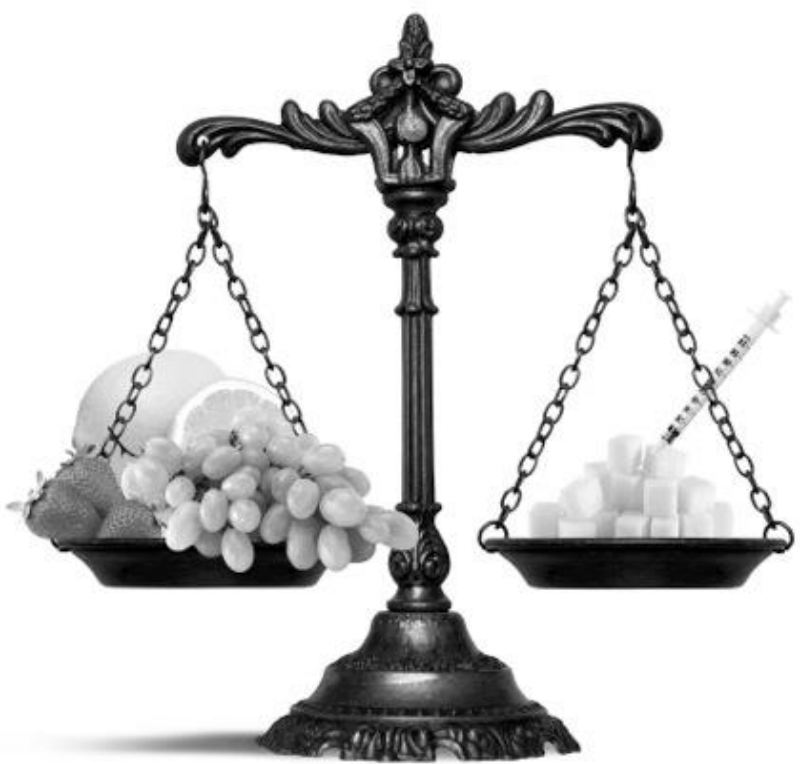


The major objective of the studies presented in this thesis was to examine the potential mechanisms by which natural compounds can help to attenuate or delay the onset of diabetic complications caused by high levels of glucose in the blood.

After presenting an introduction on regulation of glucose homeostasis in chapter 1. We focused in chapter $\mathbf{2}$ and $\mathbf{3}$ on potential protective mechanisms by polyphenols. Chapter 4 was dedicated to potential mechanisms by which glucotoxicity can (indirectly) cause damage to beta cells. Chapters 5 to 9 concentrated on the various protective mechanisms of the polyol erythritol.

Below, the most important findings are summarized and discussed. Additionally, potential implications and suggestions for future research are presented.

\section{Main Findings}

\section{Polyphenols: compounds with pleiotropic effects}

In chapter $\mathbf{2}$ we investigated the effect of chronic PARP-1 inhibition on telomere stability. As PARP-1 may have a dual role on telomere shortening under conditions of chronic oxidative stress, we used the polyphenol fisetin and the antibiotic (and known PARP-1 inhibitor) minocycline to inhibit PARP-1 under conditions of chronic oxidative stress in an in vitro model using human fibroblasts. These two compounds were chosen because they showed a different mode of inhibition. Fisetin, at a concentration of $1 \mu \mathrm{M}$, showed a mild inhibition while minocycline, at a concentration of $100 \mathrm{nM}$, almost completely inhibited PARP-1. Chronic fisetin and minocycline treatment shortened telomeres under normal conditions. Therefore precaution should be taken when fisetin and minocycline are used on a regular basis, as it could reduce telomere stability and accelerate the rate of biological aging. However, under conditions of oxidative stress fisetin and minocycline treatment reduced the rate of telomere shortening, indicating that under these circumstances PARP-1 inhibition is beneficial.

In chapter $\mathbf{3}$ we showed that flavonoids are able to protect endothelial cells against a drop in $\mathrm{NAD}^{+}$levels caused by high glucose. In this study we used the structurally related polyphenols flavone, quercetin and rutin at a concentration of $5 \mu \mathrm{M}$. We showed that these polyphenols inhibit aldose reductase, the key enzyme of the polyol pathway. However, this characteristic appears to be less important in the protection of endothelial cells than their ability to prevent PARP-1 overactivation. Overall, we concluded that the combination of all these characteristics and other known properties (e.g. antioxidant) is most likely the reason why the polyphenols showed a protective effect on $\mathrm{NAD}^{+}$levels in endothelial cells. 


\section{High glucose and the pancreatic beta cell}

In chapter 4 we describe a potential mechanism by which hyperglycemia can contribute to diabetic complications. High glucose levels lead to the formation of advanced glycation end products (AGEs) which can increase the production of reactive oxygen species. It is known that beta cells are particularly vulnerable to oxidative stress because of their low defense mechanisms. Therefore we investigated the effect of the $A G E N^{\varepsilon}$-carboxymethyllysine $(\mathrm{CML})$ on the glutathione system in beta cells. As was expected, CML incubation decreased GSH levels and affected other components of the glutathione system. Furthermore, it decreased viability and increased oxidative stress in the cells. Via this mechanism, hyperglycemia (via AGE formation) can accelerate beta cell dysfunction and increase beta cell death, thereby accelerating the severity of diabetes.

\section{Erythritol: a small polyol with big health effects}

In chapter $\mathbf{5}$ an overview of the health effects of the polyol erythritol is given. Erythritol is a non-toxic, well tolerated compound which possesses anti-cariogenic and antioxidant properties. Previously, it was shown that erythritol prevented loss of ex vivo endothelium dependent vasorelaxation in streptozotocin diabetic rats. Because its ability to scavenge hydroxyl radicals cannot solely explain this protective effect, we examined the effects of erythritol in endothelial cells exposed to normal and high glucose levels (chapter 6). We found that erythritol by itself showed no effects under normal conditions. However, under high glucose conditions erythritol reversed a number of harmful effects. On a transcriptomic level it reversed the direction of change of 148 of the 153 transcripts altered by high glucose incubation. In chapter 7 we focused on angiogenic effects of erythritol in endothelial cells. We found some anti-angiogenic effects of erythritol, which can be seen as beneficial as excessive angiogenesis, a condition occurring when the balance between pro-angiogenic and anti-angiogenic factors is disturbed, has been associated with many diseases including diabetes. In chapter 8 our scope was widened by examining the potential of erythritol to protect beta cells against glucose induced dysfunction and cell death. Again we showed that erythritol under normal conditions had little effect on the cells, while under high glucose conditions erythritol attenuated damage and improved function of the cells. Finally, in chapter 9 we examined the effect of erythritol consumption in an in vivo study with type 2 diabetes patients. We found that chronic erythritol consumption (for four weeks) did not change inflammatory status or oxidative stress markers, although a small reduction in malondialdehy (MDA) levels, a marker for lipid peroxidation, was observed. 


\section{Implications and suggestions}

\section{Polyphenols: more is not always better}

Because it is generally assumed that polyphenols are healthy, they are often added to nutritional supplements, not seldom in relatively high amounts. As we described in chapter 2, exposure of cells to physiological doses of the polyphenol fisetin under relatively normal conditions caused an increase in the rate of biological aging of cells. Since biological effects of regular consumption of high doses polyphenols are not known, thorough safety evaluation is warranted with respect to these nutritional supplements.

Some polyphenols have carcinogenic or genotoxic effects at high doses in animal studies $(1 ; 2)$. For example, the isoflavone geneistein has been implicated in the development of breast cancer (due to its estrogen-like activity) and infant leukemia (due to its ability to inhibit the enzyme topoisomerase) $(3 ; 4)$. In addition, some polyphenols affect thyroid function by inhibition of thyroid peroxidase and interference with thyroid biosynthesis (5).

Antinutritional effects of polyphenols are also described. For example, polyphenol containing beverages such as tea can reduce non-heme iron absorption by formation of insoluble complexes. This will not cause trouble in people with adequate iron stores, but may increase risk of iron depletion in individuals with marginal iron status (6). Some polyphenols can affect drug bioavailability and pharmacokinetics. This has been thoroughly investigated for grapefruit juice. Furanocoumarins present in grape juice are metabolized by CYP3A4 to form reactive intermediates that subsequently form a covalent bond with the active site of CYP3A4, thereby causing irreversible inactivation. This is a serious condition because CYP3A4 is responsible for bioinactivation of $50 \%$ of all drugs. Currently, grape juice is known to interact with over 85 drugs, interactions with 43 drugs is known to cause serious adverse effects (7).

Polyphenols present in foods and supplements generally are considered to be healthy, however precautions should be taken when polyphenols are consumed at high doses for a longer time period.

\section{Food as medicine?}

Supplementation with compounds to prevent or delay the onset of diabetic complications is most likely chronic. Therefore compounds with strong biological effects are less suitable for chronic supplementation. Alternative compounds with 
mild protective effects, as those studied in this thesis, can therefore be of importance.

The use of dietary compounds for the treatment of disease has become popular in recent years. For example, the inhibition of aldose reductase by compounds obtained from the diet, as described in chapter 3, has gained attention. Synthetic aldose reductase inhibitors showed promising results in vitro, but only a small number has reached the stadium of clinical trials where they eventually failed due to hypersensitivity reactions and liver toxicity (8). These unwanted effects could be due to a low selectivity for aldose reductase versus the closely related enzyme aldehyde reductase. Aldose reductase inhibitors from dietary sources generally show a high specificity towards aldose reductase. In addition, they are considered to be safe, as most of them are currently used in preparation of food (9).

Also the effects of dietary components on endothelial function have been more frequently investigated. Several human intervention studies show beneficial effects of polyphenols on endothelium function, in particular intake from food sources rich in flavan-3-ols (green tea and cacao) and anthocyanin (berries) (10; 11). The evidence for beneficial effects of other foods such as citrus fruit, apples and red wine is less consistent (12). The European Food Safety Authority (EFSA) has even awarded health claims to walnuts and cocoa flavanols. Consumption of 30 grams or more walnuts daily contributes to the improvement of elasticity of blood vessels (13). Consumption of $200 \mathrm{mg}$ of cocoa flavanols daily helps maintan endotheliumdependent vasodilation, which contributes to normal blood flow (14).

Many studies focus on polyphenols with regard to beneficial effects on endothelium function. In this thesis we describe the endothelium protective capacity of the polyol compound erythritol. To our knowledge, this is the first time that a polyol has been linked to improved vascular function. This ability of erythritol has been found in vitro (chapter 6), in vivo (rat) studies (15) and in a clinical study with type 2 diabetes patients (16).

\section{Beta cells under attack}

Beta cells are important in diabetes as decreased beta cell number and function underlies much of the pathology of the disease. Responding to high glucose levels in the blood, beta cells increase the production of insulin until their insulin stores become depleted which results in inadequate insulin production (17). Genetic factors, as well as several pathways, including those related to endoplasmic reticulum and oxidative stress, are known to contribute to the ultimate failure of 
beta cells to produce insulin $(18 ; 19)$. However, not much is known about the effect of AGEs on the glutathione system, a major antioxidant defense system, in the beta cell (chapter 4). We provide evidence that hyperglycemia can decrease antioxidant systems in beta cells, leading to accelerated beta cell death.

It is known that conventional diabetes treatments such as metformin and sulfonylureas do not prevent the progressive decline of beta cell function. As oxidative stress plays a major role in beta cell failure, antioxidant treatment, alone or in combination with available anti-diabetic drugs is potentially beneficial (19). Dietary sources may also prove to be effective in this case, but until now this has only been investigated in animal and in vitro models. In our studies we observed that erythritol protected beta cells from high glucose induced cell death and dysfunction in vitro (chapter 8). Similar findings were observed for grape seed proanthocyanidins and lipoic acid $(20 ; 21)$

\section{Something sweet against the bitter effects of sugar?}

Recently, the World Health Organization (WHO) released a draft guideline to change its recommendations for sugar intake (22). Currently, the WHO recommends that sugars (those added to food, as well as natural sugars) should not make up more than $10 \%$ of the total energy intake per day, whereas the newly proposed guideline reduces this number to $5 \%$. This comes down to about 25 grams ( 6 teaspoons) of sugar for an adult with normal body mass index. Since most of the sugars consumed today are 'hidden' (e.g. a can of sugar-sweetened soda contains up to 40 grams of sugar) this seems to be difficult to achieve. The change in guidelines is due to scientific evidence that excess sugar consumption increases the risk of dental decay and obesity, ultimately leading to diseases like diabetes $(23 ; 24)$. In the USA the consumption of added sugars has decreased between from $100.1 \mathrm{~g} /$ day in $1999-2000$ to $76.7 \mathrm{~g} / \mathrm{d}$ in $2007-2008$. This reduction could mainly be attributed to a decrease in soda consumption. However, the mean intake $(14.6 \%$ of daily energy intake) still exceeds the current recommendation (25).

Due to the association of high sugar intake with health risks the intake of sugar substitutes has increased in the last decade, as they provide sweetness without significantly contributing to caloric intake. Consumption of these sugar substitutes in the USA has increased substantially among all age groups since 2000 , with $28 \%$ of the total population reporting intake of sweeteners. The largest observed increases were found in beverage consumption among both children and adults (26). Sweeteners, specifically artificial sweeteners like aspartame, are often associated with health risks. This is a controversial area because there is much 
conflicting research regarding artificial sweeteners. However, EFSA and the Food and Drug Administration (FDA) state that artificial sweeteners are safe at the levels currently used in food and drinks (27).

A major part of this thesis focuses on the polyol erythritol. Erythritol is currently used as natural sweetener in beverages, chewing gum, chocolate, candies and bakery products. In consumer products erythritol is often mixed with Stevia extracts, derived from the South American Stevia Rebaudiana plant. Consumption of Stevia has been associated with lower postprandial insulin and glucose levels, a feature that could be helpful in managing postprandial hyperglycemia, an important contributor to the development of insulin resistance (28).

The work described in this thesis and work previously described (15) show that erythritol is an excellent sugar substitute for diabetic patients. Not only does it reduce the glycemic impact of a snack or beverage, it can also help to reduce the onset and progression of diabetic complications by protecting the endothelium and pancreatic beta cells against the harmful effects of high glucose concentrations.

\section{Overall conclusion}

The research described in this thesis indicates that natural compounds exert multiple effects by which they can attenuate or delay the onset of diabetic complications. Although it is often difficult to pinpoint the exact molecular mechanism by which these compounds protect the cells in our studies, it appears to be a combination of multiple small effects that is ultimately responsible for the observed effects.

Although this thesis focused on the deleterious effects of high glucose levels, which are linked to the development of diabetes and its complications, many of the mechanisms and pathways found to be affected in this thesis are also of importance in other diseases. For example, pathways which are transcriptomically affected by erythritol also play major roles in diseases like Alzheimer, prostate cancer, breast cancer and atherosclerosis. This opens up a wide range of other diseases in which long term supplementation with compounds with mild effects, as described in this thesis, may be beneficial. 


\section{References}

1. Catterall F, Souquet JM, Cheynier V, de Pascual-Teresa S, Santos-Buelga C, Clifford MN, Ioannides C: Differential modulation of the genotoxicity of food carcinogens by naturally occurring monomeric and dimeric polyphenolics. Environ Mol Mutagen 2000;35:86-98

2. Snyder RD, Gillies PJ: Evaluation of the clastogenic, DNA intercalative, and topoisomerase IIinteractive properties of bioflavonoids in Chinese hamster V79 cells. Environ Mol Mutagen 2002;40:266-276

3. Azarova AM, Lin RK, Tsai YC, Liu LF, Lin CP, Lyu YL: Genistein induces topoisomerase llbeta- and proteasome-mediated DNA sequence rearrangements: Implications in infant leukemia. Biochem Biophys Res Commun 2010;399:66-71

4. Yang X, Yang S, McKimmey C, Liu B, Edgerton SM, Bales W, Archer LT, Thor AD: Genistein induces enhanced growth promotion in ER-positive/erbB-2-overexpressing breast cancers by ERerbB-2 cross talk and p27/kip1 downregulation. Carcinogenesis 2010;31:695-702

5. Ferreira AC, Lisboa PC, Oliveira KJ, Lima LP, Barros IA, Carvalho DP: Inhibition of thyroid type 1 deiodinase activity by flavonoids. Food Chem Toxicol 2002;40:913-917

6. Temme EH, Van Hoydonck PG: Tea consumption and iron status. Eur J Clin Nutr 2002;56:379386

7. Bailey DG, Dresser G, Arnold JMO: Grapefruit-medication interactions: Forbidden fruit or avoidable consequences? Canadian Medical Association Journal 2012;

8. Chatzopoulou M, Pegklidou K, Papastavrou N, Demopoulos VJ: Development of aldose reductase inhibitors for the treatment of inflammatory disorders. Expert Opinion on Drug Discovery 2013;8:1365-1380

9. Saraswat M, Muthenna P, Suryanarayana P, Petrash JM, Reddy GB: Dietary sources of aldose reductase inhibitors: prospects for alleviating diabetic complications. Asia Pac J Clin Nutr 2008;17:558-565

10. Hooper L, Kroon PA, Rimm EB, Cohn JS, Harvey I, Le Cornu KA, Ryder JJ, Hall WL, Cassidy A: Flavonoids, flavonoid-rich foods, and cardiovascular risk: a meta-analysis of randomized controlled trials. Am J Clin Nutr 2008;88:38-50

11. Liu $Y$, Li D, Zhang $Y$, Sun $R$, Xia M: Anthocyanin increases adiponectin secretion and protects against diabetes-related endothelial dysfunction. Am J Physiol Endocrinol Metab 2014;306:E975988

12. Landberg R, Naidoo N, van Dam RM: Diet and endothelial function: from individual components to dietary patterns. Curr Opin Lipidol 2012;23:147-155

13. EFSA Panel on Dietetic Products NaAN: Scientific Opinion on the substantiation of health claims related to walnuts and maintenance of normal blood LDL-cholesterol concentrations (ID 1156,1158 ) and improvement of endothelium-dependent vasodilation (ID 1155, 1157) pursuant to Article 13(1) of Regulation (EC) No 1924/2006. . EFSA Journal 2011;9: 2074

14. EFSA Panel on Dietetic Products NaAN: Scientific Opinion on the substantiation of a health claim related to cocoa flavanols and maintenance of normal endothelium-dependent vasodilation pursuant to Article 13(5) of Regulation (EC) No 1924/2006. . EFSA Journal 2012;10:2809

15. den Hartog GJ, Boots AW, Adam-Perrot A, Brouns F, Verkooijen IW, Weseler AR, Haenen GR, Bast A: Erythritol is a sweet antioxidant. Nutrition 26:449-458

16. Flint N, Hamburg N, Holbrook M, Dorsey P, LeLeiko R, Berger A, de Cock P, Bosscher D, Vita J: Effects of erythritol on endothelial function in patients with type 2 diabetes mellitus: a pilot study. Acta Diabetol 2013:1-4

17. Talchai C, Lin HV, Kitamura T, Accili D: Genetic and biochemical pathways of beta-cell failure in type 2 diabetes. Diabetes Obes Metab 2009;11 Suppl 4:38-45

18. Scott RA, Lagou V, Welch RP, Wheeler E, Montasser ME, Luan J, Magi R, Strawbridge RJ, Rehnberg E, Gustafsson S, Kanoni S, Rasmussen-Torvik $L$, Yengo L, Lecoeur C, Shungin D, Sanna S, Sidore C, Johnson PC, Jukema JW, Johnson T, Mahajan A, Verweij N, Thorleifsson G, Hottenga JJ, Shah S, Smith AV, Sennblad B, Gieger C, Salo P, Perola M, Timpson NJ, Evans DM, Pourcain BS, Wu Y, Andrews JS, Hui J, Bielak LF, Zhao W, Horikoshi M, Navarro P, Isaacs A, O'Connell JR, Stirrups K, Vitart V, Hayward C, Esko T, Mihailov E, Fraser RM, Fall T, Voight BF, Raychaudhuri S, Chen H, 
Lindgren CM, Morris AP, Rayner NW, Robertson N, Rybin D, Liu CT, Beckmann JS, Willems SM, Chines PS, Jackson AU, Kang HM, Stringham HM, Song K, Tanaka T, Peden JF, Goel A, Hicks AA, An $P$, Muller-Nurasyid M, Franco-Cereceda A, Folkersen L, Marullo L, Jansen $H$, Oldehinkel AJ, Bruinenberg M, Pankow JS, North KE, Forouhi NG, Loos RJ, Edkins S, Varga TV, Hallmans G, Oksa H, Antonella M, Nagaraja R, Trompet S, Ford I, Bakker SJ, Kong A, Kumari M, Gigante B, Herder C, Munroe PB, Caulfield M, Antti J, Mangino M, Small K, Miljkovic I, Liu Y, Atalay M, Kiess W, James $A L$, Rivadeneira F, Uitterlinden AG, Palmer CN, Doney AS, Willemsen G, Smit JH, Campbell $S$, Polasek O, Bonnycastle LL, Hercberg S, Dimitriou M, Bolton JL, Fowkes GR, Kovacs P, Lindstrom J, Zemunik T, Bandinelli S, Wild SH, Basart HV, Rathmann W, Grallert H, Maerz W, Kleber ME, Boehm BO, Peters A, Pramstaller PP, Province MA, Borecki IB, Hastie ND, Rudan I, Campbell H, Watkins H, Farrall M, Stumvoll M, Ferrucci L, Waterworth DM, Bergman RN, Collins FS, Tuomilehto J, Watanabe RM, de Geus EJ, Penninx BW, Hofman A, Oostra BA, Psaty BM, Vollenweider P, Wilson JF, Wright AF, Hovingh GK, Metspalu A, Uusitupa M, Magnusson PK, Kyvik KO, Kaprio J, Price JF, Dedoussis GV, Deloukas $P$, Meneton $P$, Lind $L$, Boehnke M, Shuldiner AR, van Duijn CM, Morris AD, Toenjes A, Peyser PA, Beilby JP, Korner A, Kuusisto J, Laakso M, Bornstein SR, Schwarz PE, Lakka TA, Rauramaa R, Adair LS, Smith GD, Spector TD, Illig T, de Faire U, Hamsten A, Gudnason V, Kivimaki M, Hingorani A, Keinanen-Kiukaanniemi SM, Saaristo TE, Boomsma DI, Stefansson K, van der Harst P, Dupuis J, Pedersen NL, Sattar N, Harris TB, Cucca F, Ripatti S, Salomaa V, Mohlke KL, Balkau B, Froguel P, Pouta A, Jarvelin MR, Wareham NJ, Bouatia-Naji N, McCarthy MI, Franks PW, Meigs JB, Teslovich TM, Florez JC, Langenberg C, Ingelsson E, Prokopenko I, Barroso I: Large-scale association analyses identify new loci influencing glycemic traits and provide insight into the underlying biological pathways. Nat Genet 2012;44:991-1005

19. Bensellam M, Laybutt DR, Jonas J-C: The molecular mechanisms of pancreatic $\beta$-cell glucotoxicity: Recent findings and future research directions. Molecular and Cellular Endocrinology 2012;364:1-27

20. Ding Y, Zhang Z, Dai X, Jiang Y, Bao L, Li Y, Li Y: Grape seed proanthocyanidins ameliorate pancreatic beta-cell dysfunction and death in low-dose streptozotocin- and highcarbohydrate/high-fat diet-induced diabetic rats partially by regulating endoplasmic reticulum stress. Nutrition \& Metabolism 2013;10:51

21. Yang Y, Wang W, Liu Y, Guo T, Chen P, Ma K, Zhou C: alpha-lipoic acid inhibits high glucoseinduced apoptosis in HIT-T15 cells. Dev Growth Differ 2012;54:557-565

22. WHO opens public consultation on draft sugars guideline [article online], 2014. Available from http://www.who.int/mediacentre/news/notes/2014/consultation-sugar-guideline/en/.

23. Morenga LT, Mallard S, Mann J: Dietary sugars and body weight: systematic review and metaanalyses of randomised controlled trials and cohort studies. BMJ 2013;346

24. Moynihan PJ, Kelly SAM: Effect on Caries of Restricting Sugars Intake: Systematic Review to Inform WHO Guidelines. Journal of Dental Research 2014;93:8-18

25. Welsh JA, Sharma AJ, Grellinger L, Vos MB: Consumption of added sugars is decreasing in the United States. Am J Clin Nutr 2011;94:726-734

26. Sylvetsky AC, Welsh JA, Brown RJ, Vos MB: Low-calorie sweetener consumption is increasing in the United States. Am J Clin Nutr 2012;96:640-646

27. Tandel KR: Sugar substitutes: Health controversy over perceived benefits. J Pharmacol Pharmacother 2011;2:236-243

28. Anton SD, Martin CK, Han H, Coulon S, Cefalu WT, Geiselman P, Williamson DA: Effects of stevia, aspartame, and sucrose on food intake, satiety, and postprandial glucose and insulin levels. Appetite 2010;55:37-43 
Nederlandse samenvatting

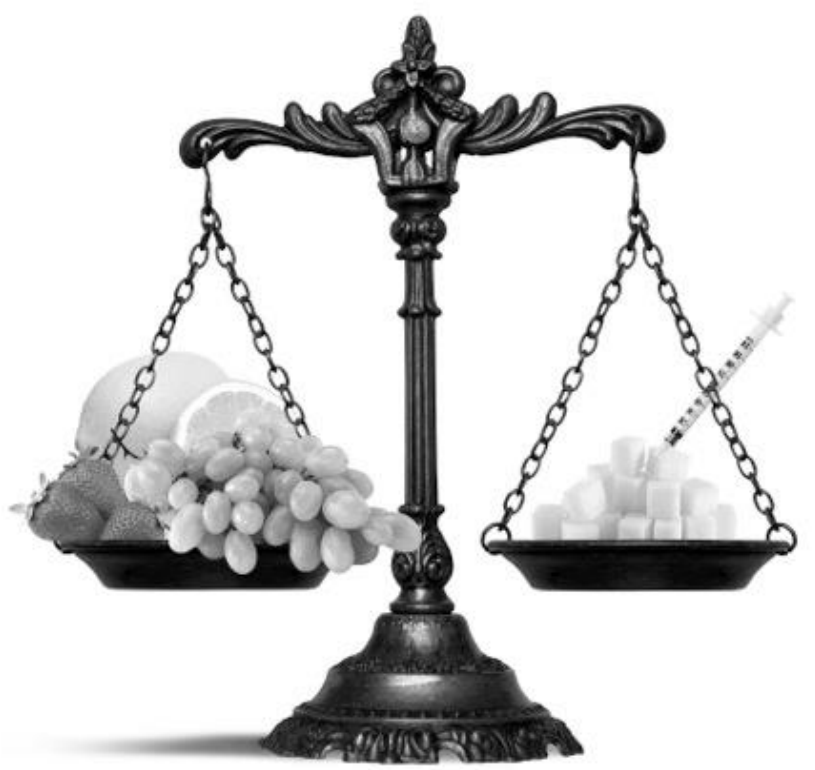


In dit proefschrift staan studies beschreven die de mechanismen bestuderen waarmee natuurlijke stoffen kunnen helpen om het ontstaan van diabetische complicaties te vertragen of voorkomen. Deze diabetische complicaties kunnen ontstaan door hoge hoeveelheden glucose in het bloed.

In hoofdstuk 1 wordt een introductie gegeven over de regulatie van glucose homeostase. In hoofdstuk $\mathbf{2}$ en $\mathbf{3}$ hebben we potentieel beschermende mechanismen van polyfenolen onderzocht. In hoofdstuk 4 hebben we onderzocht hoe glucosetoxiciteit (indirect) schade kan toebrengen aan bètacellen. In hoofdstuk 5 tot en met $\mathbf{9}$ hebben we ons gericht op de verschillende beschermende effecten van het polyol erythritol.

\section{Belangrijkste bevindingen}

\section{Polyfenolen: stoffen met pleiotrope effecten}

In hoofdstuk 2 hebben we het effect van chronische inhibitie van PARP-1 op telomeer stabiliteit onderzocht. Wij hebben de polyfenol fisetine en het antibioticum minocycline gebruikt om PARP-1 the inhiberen onder condities van chronische oxidatieve stress in een in vitro model met humane fibroblasten. Deze twee stoffen werden gekozen om hun verschil in werking. Fisetine, in een concentratie van $1 \mu \mathrm{M}$, vertoonde een milde inhibitie van PARP-1, terwijl minocycline, in een concentratie van $100 \mathrm{nM}$ een bijna volledige inhibitie van PARP-1 vertoonde. We vonden dat chronische behandeling met fisetine en minocycline leidde tot kortere telomeren in vergelijking met cellen die gekweekt waren onder normale condities. Deze resultaten laten zien dat voorzichtigheid geboden is wanneer fisetine en minocycline op een reguliere basis worden gebruikt, aangezien ze telomeerstabiliteit kunnen reduceren en daarmee de snelheid van biologische veroudering kunnen versnellen. Onder condities van chronische oxidatieve stress vonden we echter dat fisetine en minocycline telomeerverkorting juist verminderde, wat betekent dat PARP-1 inhibitie onder chronisch oxidatieve stress omstandigheden juist voordelig kan zijn.

In hoofdstuk 3 tonen we aan dat polyfenolen endotheelcellen kunnen beschermen tegen een verlaging in $\mathrm{NAD}^{+}$concentraties, veroorzaakt door hoog glucose. In de studie gebruikten we de polyfenolen flavon, quercetine en rutine in een concentratie van $5 \mu \mathrm{M}$. We toonden aan dat deze polyfenolen het belangrijkste enzym van de polyol pathway, aldose reductase, kunnen remmen. In endotheelcellen lijkt dit kenmerk echter minder belangrijk dan de eigenschap van polyfenolen om PARP-1 overactivatie te voorkomen. We concludeerden dat de combinatie van al deze kenmerken en andere bekende eigenschappen (zoals de 
werking als antioxidant) waarschijnlijk de reden is dat polyfenolen een beschermend effect op $\mathrm{NAD}^{+}$concentraties in endotheelcellen lieten zien.

\section{Hoog glucose en de bètacel van de pancreas}

In hoofdstuk 4 beschrijven we een mogelijk mechanisme waardoor hoge glucoseconcentraties kunnen bijdragen aan diabetische complicaties. Hoge glucoseconcentraties kunnen leiden tot de vorming van advanced glycation end products (AGEs), die vervolgens weer kunnen leiden tot een verhoogde hoeveelheid reactieve vormen van zuurstof. Het is bekend dat bètacellen erg kwetsbaar zijn voor oxidatieve stress omdat ze weinig verdedigingsmechanismen hebben. Daarom onderzochten we het effect van de AGE $\mathrm{N}^{\varepsilon}$-carboxymethyllysine $(\mathrm{CML})$ op het glutathion systeem in bètacellen. Behandeling van de cellen met $\mathrm{CML}$ leidde tot een verlaging van glutathion (GSH) concentraties en beïnvloedde ook andere componenten van het glutathion systeem. Eveneens verlaagde het de vitaliteit van de cellen en verhoogde de hoeveelheid oxidatieve stress. Via dit mechanisme kunnen hoge glucoseconcentraties (via vorming van AGEs) leiden tot een versnelde dysfunctie van de bètacel en een verhoging in dood van bètacellen.

\section{Erythritol: een kleine polyol met grote gezondheidseffecten}

In hoofdstuk $\mathbf{5}$ hebben we een overzicht gegeven van de gezondheidseffecten van erythritol. Het is een niet-toxisch, goed getolereerde stof die anti-cariogene en antioxidante eigenschappen heeft. In een vorige studie is aangetoond dat erythritol endoltheeldysfunctie in streptozotocine geïnduceerde diabetische ratten kon voorkomen. Omdat dit beschermend effect niet alleen kan worden uitgelegd door de eigenschap van erythritol om hydroxyl radicalen weg te vangen, hebben we de effecten van erythritol verder onderzocht in endotheelcellen die blootgesteld werden aan normale en hoge glucoseconcentraties (hoofdstuk 6). We vonden dat erythritol zelf geen effect had onder normale omstandigheden. Echter, in de situatie met hoge glucoseconcentraties kon erythritol enkele schadelijke effecten tegengaan. Op gentranscriptieniveau, veranderde het 148 van de 153 genen terug die beïnvloedt waren door hoog glucose. In hoofdstuk 7 hebben we het effect op endotheelcellen verder onderzocht, nu gericht op angiogenese, het fysiologische proces van nieuwe bloedvatformatie vanuit bestaande vaten. We vonden enkele anti-angiogene effecten van erythritol. Dit kan als voordelig worden gezien omdat overmatige angiogenese, een conditie waarbij de balans tussen pro-angiogene en anti-angiogene factoren verstoord is, geassocieerd wordt met verschillende ziektebeelden, inclusief diabetes. In hoofdstuk 8 hebben we onderzocht of erythritol bètacellen kan beschermen tegen door hoge concentratie glucose geïnduceerde celdood. Ook hier vonden we dat erythritol zelf weinig effect had op 
de cellen, terwijl in de situatie van hoge glucoseconcentraties erythritol schade en celdood kon voorkomen. Tenslotte hebben we in hoofdstuk 9 het effect van erythritol consumptie onderzocht in een in vivo studie met type 2 diabetes patiënten. Chronische erythritol consumptie (4 weken) leidde niet tot veranderingen in markers van inflammatie of oxidatieve stress, hoewel een kleine vermindering in malondialdehyde (MDA) concentraties, een marker voor vetoxidatie, werd gevonden in het plasma. 


\section{Valorization addendum}

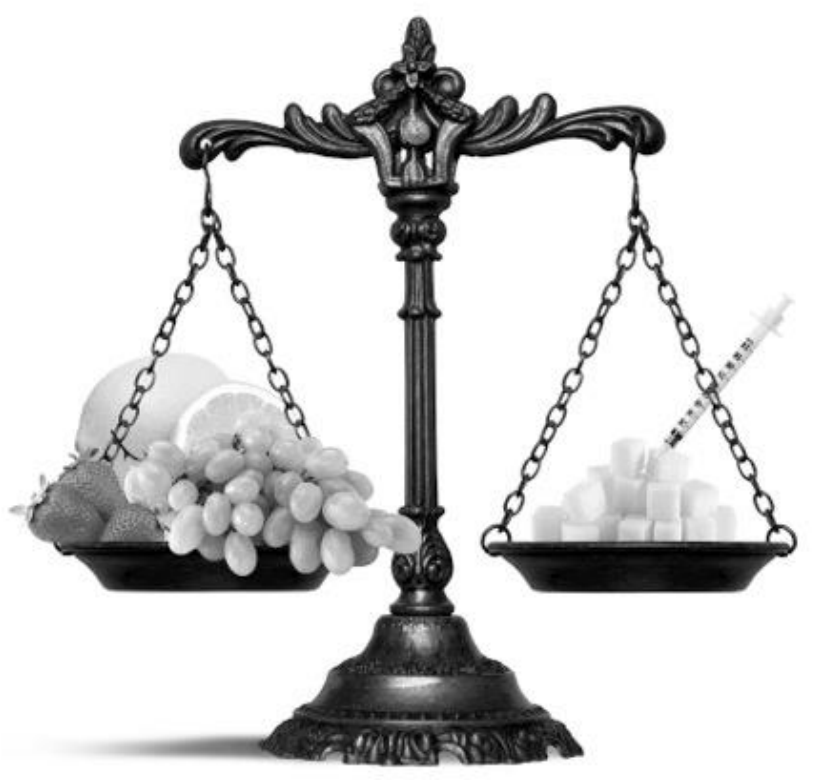




\section{Relevance}

The focus of this thesis is how natural compounds can influence the toxic effects of glucose. These toxic effects can arise during hyperglycemia, i.e. when glucose levels in the blood are high. Diabetes, one of the most prevailing chronic diseases has hyperglycemia as a hallmark. Diabetes is a global problem with over 380 million people worldwide suffering from the disease. For the Netherlands it is known that about 1 million people have diabetes (8.5\% of the population), making it the most common chronic disease of the country. Also more regional in Limburg, the province where Maastricht University is located, diabetes has a high prevalence. In adults (up to 65 years) the prevalence is $5 \%$, but in the age-group above 65 years more than $19 \%$ has diabetes. Since the population in Limburg is aging, this number will increase in the future.

Many people with diabetes develop complications like cardiovascular disease, kidney and nerve damage. These can impose a large economic burden on individuals and families, but also on national health systems and countries. Global health spending for treatment of diabetes and management of the complications totaled at least 548 billion US Dollars, which is almost $11 \%$ of the total health expenditure worldwide in 2013. In the Netherlands the costs are at least 1 billion euro (in 2007). Complications due to diabetes are major causes of early death. In 2013, diabetes caused 5.1 million deaths, which means that every six seconds a person died of diabetes. In the Netherlands about 2800 people die of diabetes each year.

These numbers show that diabetes is a global health and economic problem. Reducing the development of complications by natural compounds, as described in this thesis, can therefore be of importance to reduce the health burden as well as the economic burden.

\section{Target Groups}

People suffering from diabetes are the most important group that can ultimately benefit from the research described in this thesis. Diabetic patients can obtain a lot of information about their disease and its treatments via their general practitioner, brochures or on the internet (figure 1). Informing them through these channels about the potential beneficial effects of natural compounds is a possibility. However as also described in the discussion part, many of the pathways and mechanisms found to be affected in this thesis are also of importance in other diseases. This opens up a wide range of other diseases in which long term 
supplementation with compounds with mild effects, as described in this thesis, may be beneficial.

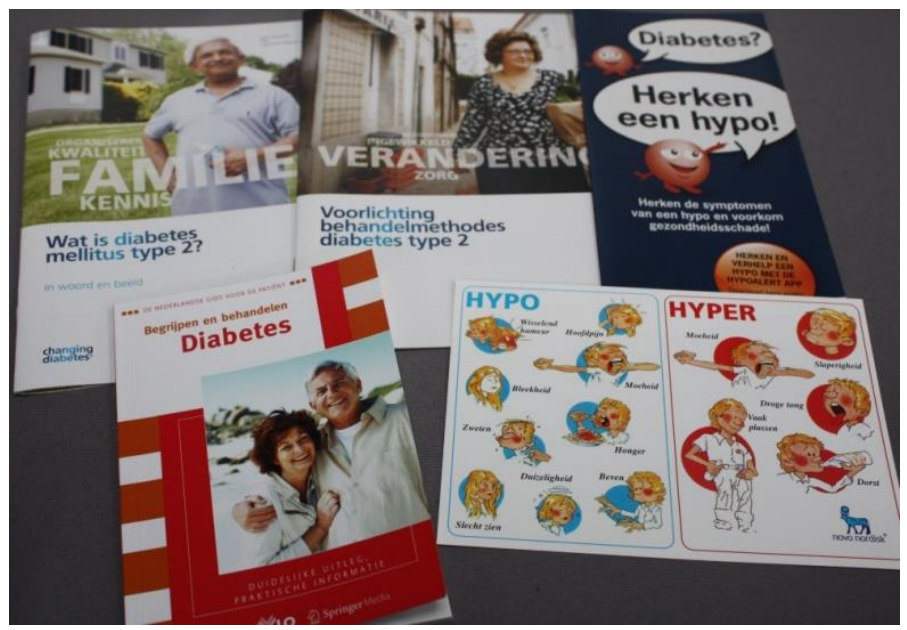

Figure 1: A selection of brochures that can be found at the GP practice to inform diabetic patients about the disease and its treatments.

\section{Activities/Products}

Compounds described in this thesis are already part of a normal diet. For example, consumption of erythritol from its natural occurrence in foods has been estimated to be $80 \mathrm{mg}$ per day ( $1.3 \mathrm{mg} / \mathrm{kg}$ body weight per day) in the United States. Erythritol intake from dietary sources in motivated groups (e.g. persons with diabetes) can increase to 4 grams per day (67 mg/kg body weight). In addition to intake via its natural sources, erythritol can also be consumed via its wide range of food applications. As erythritol also has the bulk sweetening properties of sugar, its use as a healthy choice for bakery products is also increasing and numerous recipes can be found online. The main intake of erythritol will most likely be via its use as table top sweetener or via soft drinks. This makes it relatively easy for diabetic patients to consume erythritol as a sugar substitute, to reduce the glycemic impact of a snack or a beverage but to also help to reduce the onset and progression of diabetic complications.

\section{Innovation}

Although the beneficial effects of polyphenolic compounds on endothelial function have been described before, this is the first time that a polyol has been linked to 
improved vascular function. This ability of erythritol has been found in vitro, in vivo (rat) studies and in a clinical study with type 2 diabetes patients.

The originality of this find, that a sweetener is able to protect the endothelial cells from the damaging effects of high glucose, was shown when the article about this research was published in Plos One. After publication, we received several requests for interviews about our research and the articles can be found on several Dutch websites, magazines and a newspaper (figure 3 ). The media coverage also showed that the public was very interested in this research, as the article in "De Limburger" was on the day of publication by far the most popular on the website of the newspaper.

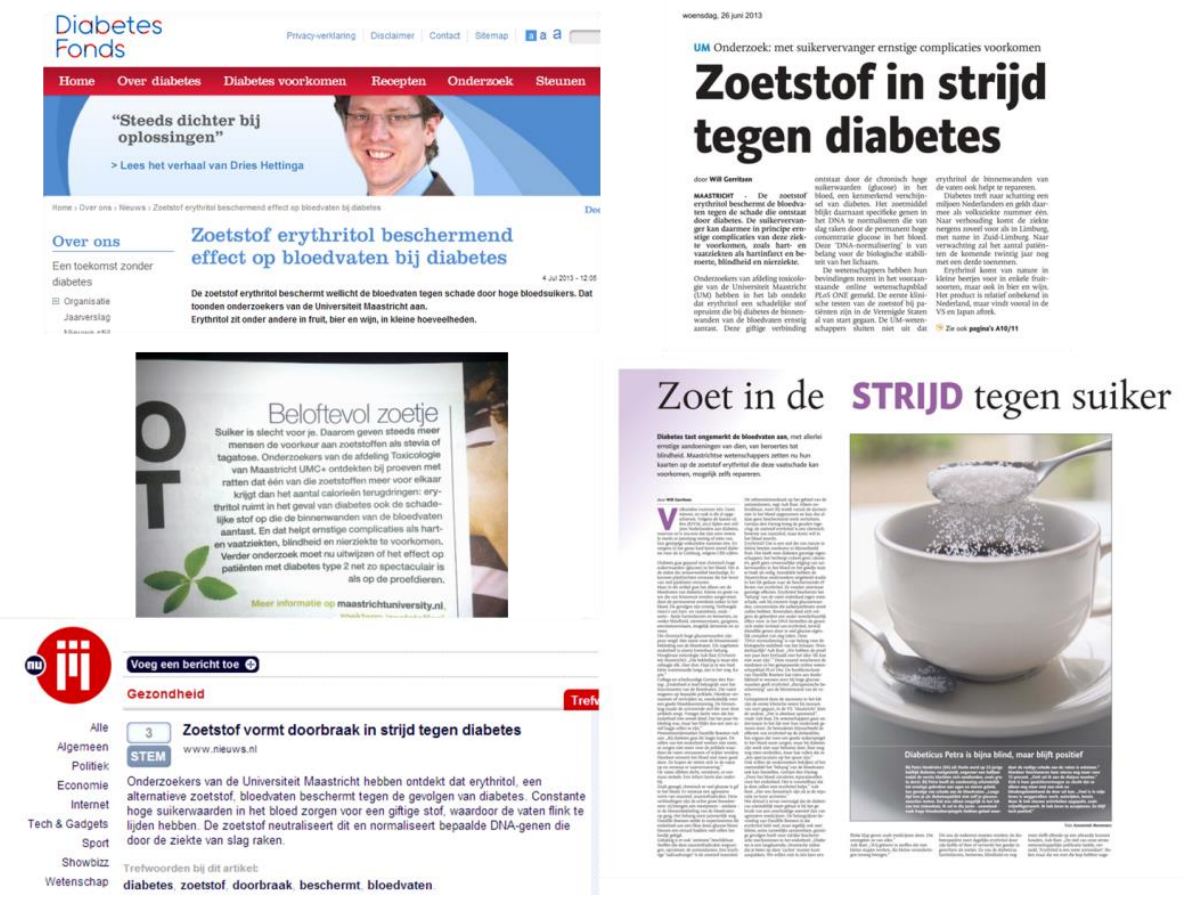

Figure 2: Publication of the endothelial protective effects of erythritol attracted a lot of media attention

\section{Schedule and implementation}

The research with erythritol is ongoing. A pilot study into the endothelial protective effects has already been finished and is partly described in this thesis. A follow-up study in which different dose-dependent effects of erythritol on endothelial function are measured is currently in progress. 


\section{Dankwoord}

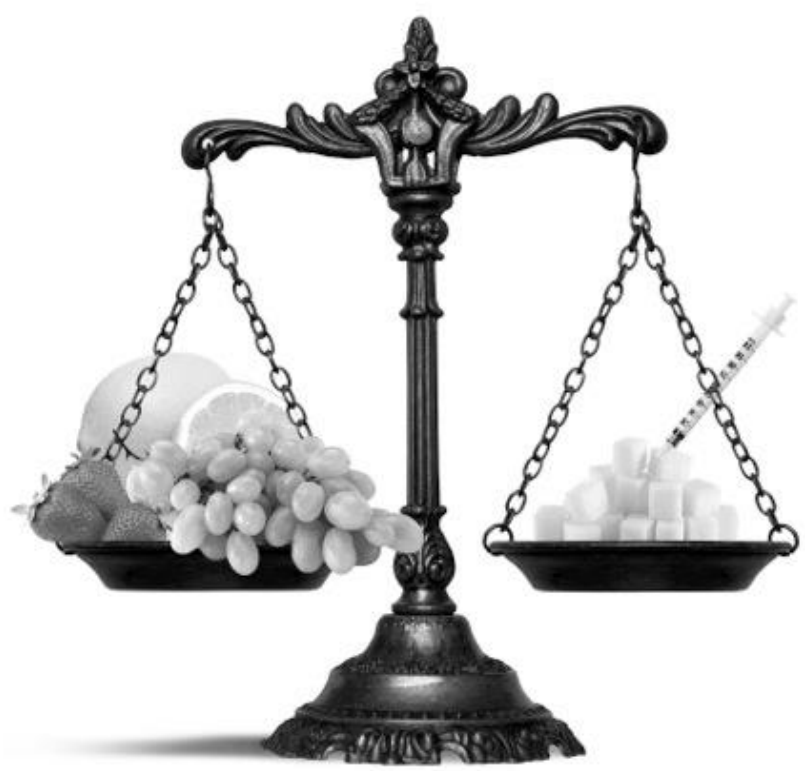


Bijna is het dan zover: het boekje is bijna af. Maar eerst natuurlijk nog het meest gelezen onderdeel van het proefschrift, het dankwoord. Toen ik de bassischool ging verlaten schreef de meester voor iedere leerling op een kaart wat hij dacht dat diegene later zou worden. Bij mij stond "schrijfster", hij heeft toch een beetje gelijk gekregen, hoewel het denk ik niet is op de manier die hij had gedacht. Ik heb toch maar mooi een boekje geschreven! Maar dat boekje was er natuurlijk nooit gekomen zonder de hulp van anderen.

Een promovendus is natuurlijk nergens zonder een geweldig promotieteam. Daarom wil ik ten eerste Prof. dr. Aalt Bast en dr. Gertjan den Hartog bedanken. Bedankt voor al jullie enthousiasme en motiverende begeleiding! Jullie hebben me altijd vrij gelaten in mijn experimenten en wanneer ik er dan even niet uitkwam hielpen jullie me door de resultaten van een positieve kant te bekijken en advies te geven hoe verder te gaan. Ik heb heel veel van jullie geleerd. Gertjan, jij ook nog bedankt voor het leuke idee voor de cover! Heren, heel erg bedankt voor de aangename samenwerking en voor alle raad en ondersteuning!

Natuurlijk wil ik ook de mensen van Cargill bedanken die betrokken zijn bij dit project. Peter de Cock, bedankt voor alle kritische vragen tijdens onze vergaderingen, dit heeft geholpen het onderzoek nog beter te maken. Ook heel erg bedankt voor de hulp bij het schrijven van met name het review over erythritol. Ook de andere mensen van het erythritol team: Alvin Berger, Douwina Bosscher, Angela Bonnema en Anne Franck, heel erg bedankt voor alle hulp tijdens mijn onderzoek!

Daarnaast wil ik ook graag de leden van de beoordelingscommissie hartelijk bedanken voor het beoordelen van mijn proefschrift.

Dan wil ik natuurlijk de rest van de afdeling Toxicologie bedanken voor alle gezelligheid en hulp tijdens mijn promotie. Er zijn in die tijd nieuwe mensen gekomen maar ook mensen weggegaan, dus ik hoop dat ik niemand ga vergeten. Erik, tegelijk begonnen en ook tegelijk klaar! Heel veel succes met jouw eigen verdediging, ik verwacht chocoladecake na afloop ;-). Dear Agnieszka, dziękuję! Thanks for all the fun times and the great Polish cakes! It was good to have you as a neighbor, I could always come in for a chat! Good luck with finishing your thesis!!! Alie, ik denk dat het maar goed is dat wij nooit op 1 kamer hebben gezeten, wij kletsen te veel ;-). Bedankt voor alle gezelligheid! Matt, I will write this in Dutch, I know you understand it! Bedankt voor de gezellige tijd, de zang die door de gang galmde vroeg in de ochtend en de leuke nabesprekingen van Game of Thrones en Da Vinci's Demons. Heel veel succes met je postdoc in Vermont! Rianne en Misha, jullie zijn begonnen toen ik al zo goed als weg was. Ik wens jullie heel veel succes maar vooral ook veel plezier tijdens jullie AIO-periode bij toxicologie. Ook de AIO's die al een tijd weg zijn Jiska, Merel, Max en Nuria, heel erg bedankt voor al jullie advies en gezellige babbels. 
Marie-Claire, dankjewel voor al het regelwerk met betrekking tot mijn promotie! Het heeft wat tijd gekost maar na een paar belrondes hebben we dan toch een datum gevonden! Geja, heel hartelijk bedankt voor je begeleiding tijdens mijn senior stage en de hulp bij het schrijven van het artikel erover. Ik weet niet wat je precies tegen Aalt hebt gezegd maar mede dankzij jou heb ik deze promotieplek gekregen. Heel erg bedankt daarvoor. Antje, bedankt voor alle gezelligheid, ik zal onze whale watching trip in Californië nooit vergeten! Wat was dat toch prachtig! Guido, bedankt voor al je advies! Marie-José, jij hebt me heel erg geholpen in mijn laatste jaar door nog wat metingen uit te voeren voor me. Heel erg bedankt daarvoor! Roger B. heel erg bedankt voor alle leuke uitjes die je hebt georganiseerd. Esther, bedankt voor al je hulp met de Luminex en alle gezellige babbels. Agnes, heel hartelijk bedankt voor al je advies, het verliezen van die $s$ is inderdaad wel fijn! Jan, bedankt voor de mooie vogel die je als cadeau had achtergelaten voor Bregje en mij in onze nieuwe kamer, die heeft nog een hoop gesprekken opgeleverd omdat iedereen zich afvroeg hoe we daaraan kwamen! Marieke, bedankt voor alle hulp en advies bij het afronden en drukken van het boekje. Pieter, bedankt voor alle hulp met de computer/laptop! Ook alle andere (ex)leden van de afdeling Els, Kimberly, Roger G., Agnieszka S, Frederik-Jan, Joy, Leonie, Edwin, Lou, Daniëlle P. heel erg bedankt voor de aangename werksfeer!

Natuurlijk wil ik ook mijn stagiaires Atlanta Elie en Saskia von Ungern-Sternberg hartelijk bedanken voor alle inzet tijdens hun stage. Het heeft toch maar mooi twee artikelen opgeleverd! Ik wens jullie heel veel succes met jullie eigen carrière. Andere stagiaires die hebben rondgelopen bij tox wil ik ook nog graag bedanken voor de gezellig tijd, met name Marike (nog een keertje koffie doen?) Nathalie (bedankt voor de hulp bij al die celtellingen!) en Mireille (zelfs een paar maanden mijn kamergenootje, heel veel succes met jouw PhD!).

Als promovendus is het belangrijk om je kamer te delen met mensen waarmee je goed overweg kunt. En dat was voor mij zeker het geval. Hilde en Bregje, jullie waren geweldige kamergenootjes! Hilde, ik ben blij dat we elkaar nog regelmatig zien voor een gezellige spelletjes of dansavond. Het bezoek aan EB in San Diego was toch wel één van de hoogtepunten. Wat hebben we daar een goede tijd gehad, misschien moeten we nog maar eens teruggaan naar die Italiaan met de toetjeskar op Coronado! Bregje, nadat Hilde weg was bleven we met zijn tweetjes over (hoewel we wel nog een paar keer verhuisd zijn). Ook met jou heb ik een congres gezocht, in Londen, dat was zeer gezellig samen met Lize en Kristien in de family room. Vier meiden, 1 week bij elkaar op de kamer en geen ruzie, dat is toch wel erg knap! Ik denk dat we toch nog een keertje met zijn allen een citytrip moeten doen (Parijs was het toch?)! Meiden, bedankt dat ik jullie kamergenoot mocht zijn, bedankt voor de fijne tijd en alle gesprekjes (van serieus tot helemaal niet serieus) en adviezen! Ik hoop dat we elkaar nog vaak zullen zien!

Naast onze eigen afdeling, had ik ook veel contact met de buren. Sandra en Karen, heel erg bedankt voor alle adviezen met de celkweek en dat ik altijd even langs 
mocht komen om te kletsen of vakantiefotoalbums te kijken! Sandra, ook heel erg bedankt voor het runnen van de microarrays! Marlon, mijn vrijdagmiddag-treinmaatje (hoewel dat ook er verminderde in het laatste jaar), altijd gezellig om even bij te praten! Dennie, bedankt voor de hulp met de aanvraag voor de reisbeurzen van de NVT. Marcel, bedankt voor alle hulp met de celkweek in jullie lab. Lize, ooit samen stage gelopen bij neuro en toen liep je ineens bij de buren rond. Leuk om jou weer tegen te komen en te kletsen over allerlei reizen die we ooit nog kunnen maken.

Zoals in één van mijn stellingen staat is de afdeling behoorlijk internationaal georiënteerd. Dat betekent ook dat ik kennis heb mogen maken met een heleboel leuke mensen afkomstig van verschillende landen. Maria, you were my roommate for a few months when I was still working at GRAT. I will always remember your

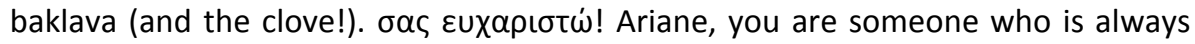
positive and happy. I always enjoyed our ABC dinners! Thank you so much for showing me and Leen around in your beautiful city San Sebastian and of course thank you for the opportunity to experience a Spanish/Italian wedding! That was wonderful. I really hope we keep up with our annual $A B C$ dinners, somewhere in Europe! Gracias!! Thalita, you crazy Brazilian girl! We had some good times on the lab (with your invisible hair dye) and during coffee breaks. I hope I can visit you one day in São Paulo or maybe we see each other again in the Netherlands. Obrigada! Gesiele, although you started when I was gone, we had some fun times during AIOdinners and during my visits to Maastricht. I hope you have a lot of fun during your time at Toxicology (and that you will also get some good results out of it!).

En dan natuurlijk mijn paranimfen. Kristien en Leen, mijn twee rustige Belgische steunpunten tijdens de verdediging. Kristien, wij kennen elkaar sinds mijn stagetijd bij GRAT. Ik ben blij dat je daarna ook bij toxicologie bent komen promoveren, daardoor hebben we beter contact gekregen. Zoals ik bij Bregje al schreef hebben we goede tijd gehad in LONDON baby! Wat hebben gelachen met die Jack the Ripper tour of die vrouw die het had over "this is a restaurant, you have to eat something". Ook onze andere uitjes waren erg gezellig, zo kan ik me nog herinneren dat we (of eigenlijk vooral jij) in de trein naar het "mooie" Amsterdam nog aan het afscheidscadeau voor Thalita zat te werken, waardoor er allemaal boa veren door de treinwagon slingerden. Ik ben blij dat je tijdens de verdediging achter me zal staan en ik wens je alvast heel veel succes met het afronden van je eigen proefschrift! Leen, jij bent begonnen als mijn begeleidster tijdens de senior stage. Ik heb het vaker gezegd, maar (bijna) alles wat ik kan op het lab heb ik van jou geleerd! Ik ben blij dat we nog heel goed contact hebben gehouden, ook nadat jij weg was uit Maastricht. We zijn zelfs een keertje samen een weekendje weg geweest om Ariane te bezoeken. Dat was zeker voor herhaling vatbaar! Ook jij heel erg bedankt dat je mijn paranimf wilt zijn. Ik heb eigenlijk ook een derde paranimf, en dat is Joyce. Joyce, ook jij was mijn begeleidster tijdens mijn senior stage, en eigenlijk ben je dat af en toe nog. Het is altijd fijn om met jou te praten en je advies te krijgen over onderzoek, wetenschap en andere zaken. Daarom, jij ook heel erg 
bedankt voor al die gezellige praatjes tijdens de koffie of tijdens etentjes de afgelopen jaren en ik hoop dat daar nog velen van gaan komen!

Vier jaar Maastricht (en eigenlijk ook nog 5 jaar daarvoor voor studie) betekent ook veel treinritten. Dat "leed" werd wel een beetje verlicht door de aanwezigheid van mijn medereisgenoten. Door de jaren heen zijn die wel veranderd, maar toch heel erg bedankt Helma, Anke, Sjoerd, Marcel, Caroline, Vera, Ellen, Ilona en al die andere bekende onbekende mensen (die je beter leert kennen tijdens vertragingen). Door jullie verliepen die 40 minuten van Echt naar Maastricht Randwyck altijd lekker snel!

Ten slotte wil ik mijn familie bedanken. Pap en mam, ik denk dat jullie nog steeds niet helemaal snappen wat ik precies heb gedaan maar trots zijn jullie wel (dat was wel te zien nadat het krantenartikel in de Limburger was verschenen). Bedankt dat jullie me altijd alle vrijheid hebben gegeven qua (studie)mogelijkheden, dat heeft me mede zover gebracht. Bert en Maria, heel erg bedankt voor alle steun en interesse in mijn onderzoek. Chrystel (mijn liefste schoonzusje), Ronald, Bart en Roel, heel erg bedankt voor de ontspanning tussen het onderzoek door! En natuurlijk Antoine, we zijn nu al een hele tijd samen en hebben dus ook al veel meegemaakt. Ik wil je bedanken voor alle steun tijdens de promotieperiode! Ich haaj van dich :)! 'T Beukske is noe eindelik aaf! 
Curriculum vitae

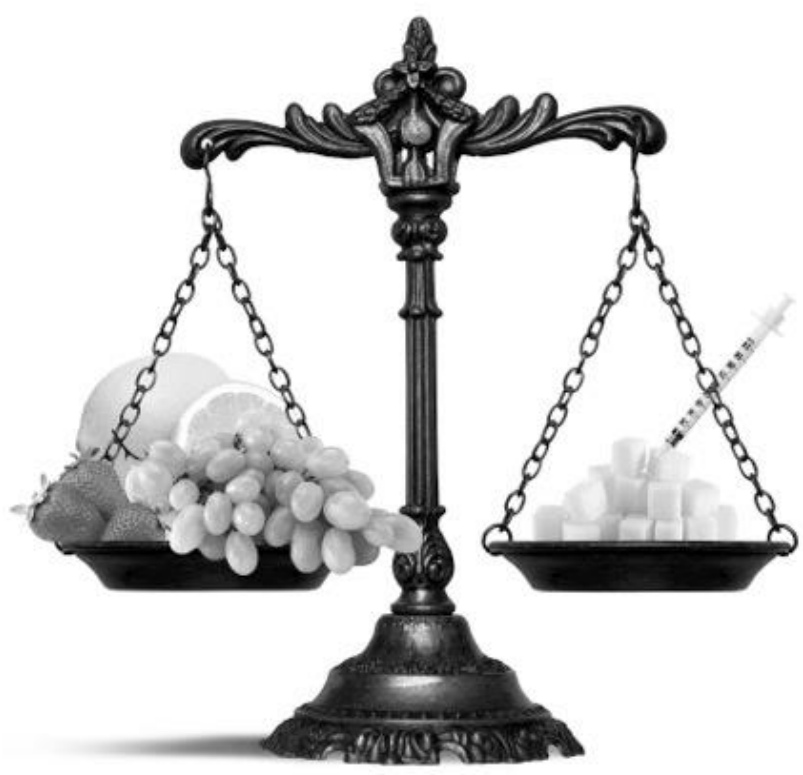




\section{Curriculum Vitae}

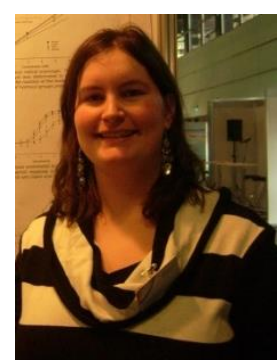

Daniëlle Boesten was born on October 9th 1985 in Roermond, The Netherlands. After finishing secondary school at "BC Schöndeln" in Roermond, she started in 2004 with the study "Molecular Life Sciences" at Maastricht University. She did her master internship at the department of Health Risk Analysis and Toxicology at Maastricht University, where she investigated the role of PARP-1 on telomere stability during chronic oxidative stress. In December 2009, she started her $\mathrm{PhD}$ project at the department of Toxicology at Maastricht University. The research performed during this project, under supervision of prof. dr. A. Bast and dr. G.J.M. den Hartog, is described in this thesis. She obtained travel grants of the Society of Toxicology (NVT) to attend the annual "Experimental Biology" conference in San Diego, USA and the annual Islet Study Group meeting in Sitges, Spain. She also obtained the Cambridge certificate of proficiency in English. 
List of publications

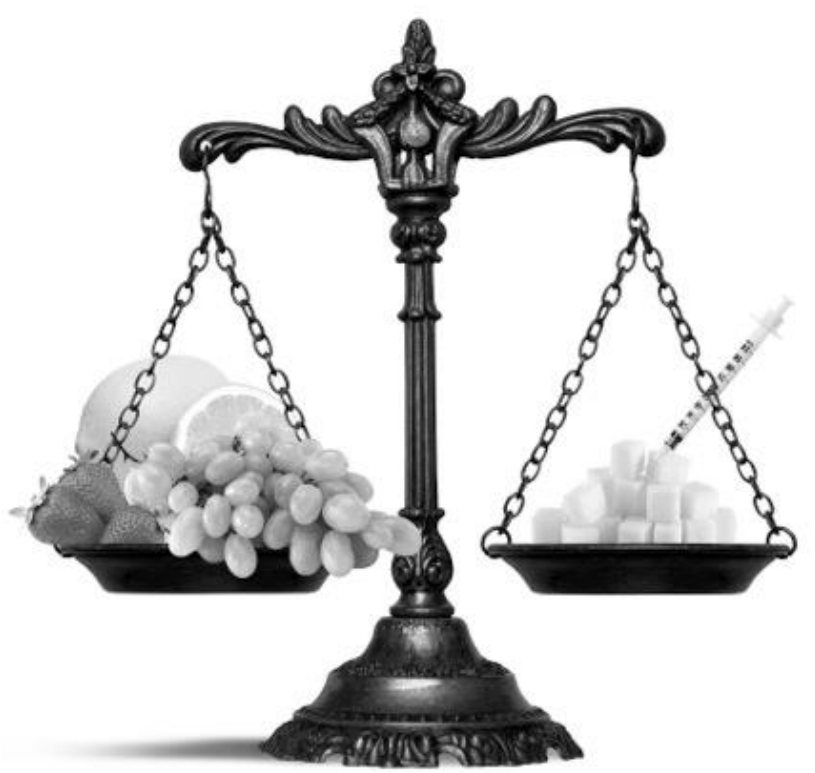




\section{Full Papers}

Boesten DMPHJ, Berger A, de Cock P, Dong H, Hammock BD, den Hartog GJM, Bast A. (2013) Multi Targeted Mechanisms Underlying the Endothelial Protective Effects of the Diabetic-Safe Sweetener Erythritol. PLoS One 8: e65741

Boesten DMPHJ, de Vos-Houben JM, Timmermans L, den Hartog GJM, Bast A, Hageman GJ (2013) Accelerated Aging during Chronic Oxidative Stress: A Role for PARP-1. Oxidative Medicine and Cellular Longevity 2013: 10.

Boesten DMPHJ, Elie AGIM, Drittij-Reijnders MJ, den Hartog GJM, Bast A. Effect of $\mathrm{N} \varepsilon$-carboxymethyllysine on pancreatic beta cells with a focus on the glutathione system. Toxicology Reports (Accepted for publication)

Boesten DMPHJ, den Hartog GJM, de Cock P, Bosscher D, Bonnema A, Bast A. Health effects of erythritol. (Submitted)

Boesten DMPHJ, den Hartog GJM, de Cock P, Bosscher D, Bast A. Erythritol protects HIT-T15 cells from high glucose induced damage. (Submitted)

Boesten DMPHJ, von Ungern-Sternberg SNI, den Hartog GJM, Bast A. Protective pleiotropic effect of flavonoids on $\mathrm{NAD}^{+}$levels in endothelial cells during high glucose. (Submitted)

Berger A, Boesten DMPHJ, de Cock P, den Hartog GJM, Bast A. Transcriptomic profiling reveals mechanisms underlying cell survival properties of the nonglycemic sweetener erythritol in endothelial cells exposed to high glucose. (Submitted)

\section{Abstracts}

Boesten DMPHJ, den Hartog GJM, Bast A. Endothelial protective effects of erythritol.

Biomedica, 17-18 March 2010, Aachen, Germany

Boesten DMPHJ, de Vos-Houben JM, Timmermans L, den Hartog GJM, Bast A, Hageman GJ. Accelerated aging during chronic oxidative stress: a role for PARP-1? Experimental Biology, 21-25 April 2012, San Diego, USA (The FASEB Journal. 2012;26:939.1) 
Boesten DMPHJ, von Ungern-Sternberg SNI, den Hartog GJM, Bast A. Protective pleiotropic effect of flavonoids on $\mathrm{NAD}^{+} / \mathrm{NADH}$ status during hyperglycemia.

Society for Free Radical Research International meeting, 6-9 September 2012, London, UK

NUTRIM day, 12 December 2012, Maastricht, The Netherlands

Meeting of the Netherlands Society of Toxicology 5-6 June 2013, Zeist, The Netherlands

Boesten DMPHJ, den Hartog GJM, de Cock P, Bosscher D, Bast A. Beta cell dysfunction during hyperglycemia: protective role of erythritol? Experimental Biology, 20-24 April 2013, Boston, USA (The FASEB Journal. 2013;27:637.1)

Islet Study Group meeting, 27-29 September 2013, Sitges, Spain 